DOE/ID-22233

Prepared in cooperation with the U.S. Department of Energy

\title{
Water-Quality Characteristics and Trends for Selected Wells Possibly Influenced by Wastewater Disposal at the Idaho National Laboratory, Idaho, 1981-2012
}

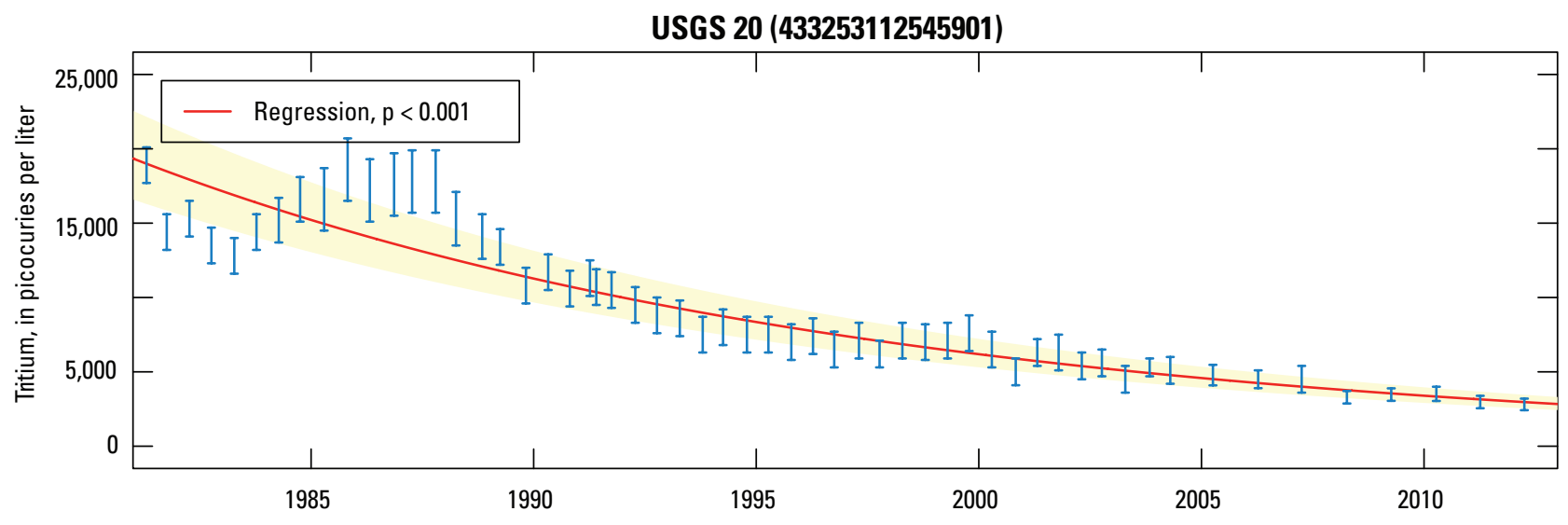

USGS 87 (433013113024201)

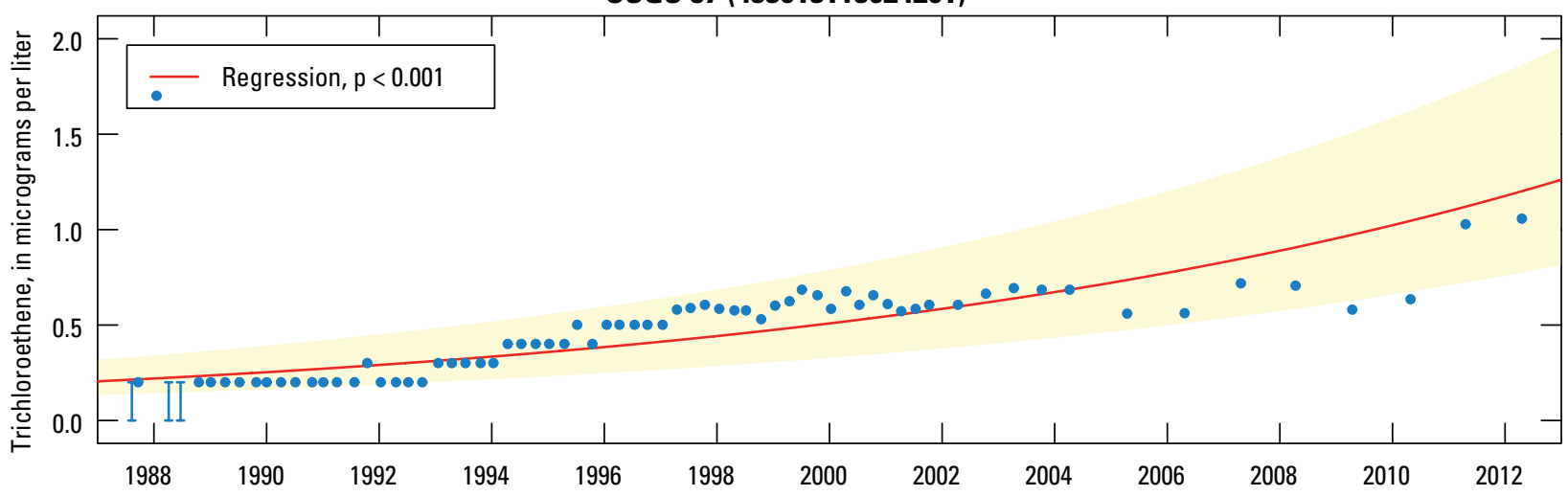

Scientific Investigations Report 2015-5003 
Cover: Graphical presentations showing decreasing trending interval censored tritium data from well USGS 20 and increasing trending left censored trichloroethene data from well USGS 87. 


\section{Water-Quality Characteristics and Trends for Selected Wells Possibly Influenced by Wastewater Disposal at the Idaho National Laboratory, Idaho, 1981-2012}

By Linda C. Davis, Roy C. Bartholomay, Jason C. Fisher, and Neil V. Maimer

DOE/ID-22233

Prepared in cooperation with the U.S. Department of Energy

Scientific Investigations Report 2015-5003 


\title{
U.S. Department of the Interior SALLY JEWELL, Secretary
}

\section{U.S. Geological Survey \\ Suzette M. Kimball, Acting Director}

\author{
U.S. Geological Survey, Reston, Virginia: 2015
}

For more information on the USGS - the Federal source for science about the Earth, its natural and living resources, natural hazards, and the environment, visit http://www.usgs.gov or call 1-888-ASK-USGS.

For an overview of USGS information products, including maps, imagery, and publications, visit http://www.usgs.gov/pubprod

To order this and other USGS information products, visit http://store.usgs.gov

Any use of trade, firm, or product names is for descriptive purposes only and does not imply endorsement by the U.S. Government.

Although this information product, for the most part, is in the public domain, it also may contain copyrighted materials as noted in the text. Permission to reproduce copyrighted items must be secured from the copyright owner.

Suggested citation:

Davis, L.C., Bartholomay, R.C., Fisher, J.C., and Maimer, N.V., 2015, Water-quality characteristics and trends for selected wells possibly influenced by wastewater disposal at the Idaho National Laboratory, Idaho, 1981-2012: U.S. Geological Survey Scientific Investigations Report 2015-5003 (DOE/ID-22233), 106 p., http://dx.doi.org/10.3133/ sir20155003.

ISSN 2328-0328 (online) 


\section{Contents}

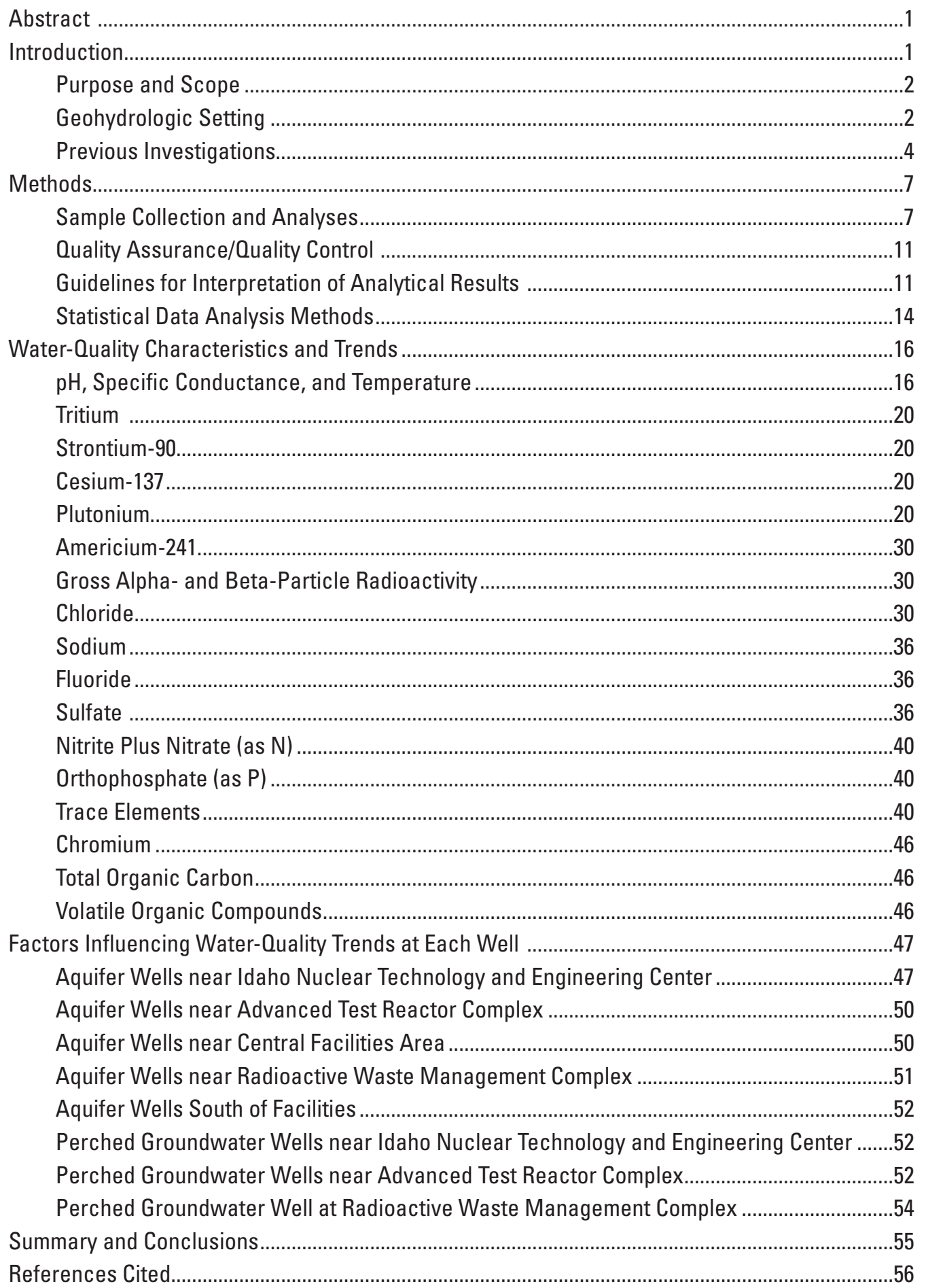




\section{Contents-Continued}

Appendixes

Appendix A. Package 'Trends' and Processing Instructions for the 2014 Trend Analysis..105

Appendix B. Plots of Trend Analyses for $\mathrm{pH}$, Specific Conductance, and Water

Temperature from Selected Sites, 1989-2012. 105

Appendix C. Plots of Trend Analyses for Selected Radiochemical Constituents from Selected Sites, 1981-2012. 105

Appendix D. Plots of Trend Analyses for Selected Constituents from Selected Sites, 1989-2012. 105

Appendix E. Plots of Trend Analyses for Volatile Organic Compounds from Selected Sites, 1987-2012.

\section{Figures}

1. Map showing locations of selected facilities at the Idaho National Laboratory, Idaho

2. Map showing locations of wells in the eastern Snake River Plain aquifer at and near the Idaho National Laboratory, Idaho

3. Map showing locations of wells in the eastern Snake River Plain aquifer at and near the Advanced Test Reactor Complex, the Idaho Nuclear Technology and Engineering Center, and the Radioactive Waste Management Complex, Idaho National Laboratory, Idaho.

4. Map showing locations of perched groundwater wells at and near the Advanced Test Reactor Complex, the Idaho Nuclear Technology and Engineering Center, and the Radioactive Waste Management Complex, Idaho National Laboratory, Idaho

5. Map showing areal distribution of specific conductance trends in water from selected aquifer wells at and near the Idaho National Laboratory, Idaho

6. Map showing areal distribution of specific conductance trends in water from selected aquifer wells at the Advanced Test Reactor Complex, Idaho Nuclear Technology and Engineering Center, and the Radioactive Waste Management Complex, Idaho National Laboratory, Idaho

7. Map showing areal distribution of specific conductance trends in water from selected perched groundwater wells at the Advanced Test Reactor Complex, Idaho Nuclear Technology and Engineering Center, and the Radioactive Waste Management Complex, the Idaho National Laboratory, Idaho.

8. Map showing areal distribution of temperature trends in water from selected aquifer wells at and near the Idaho National Laboratory, Idaho

9. Map showing areal distribution of temperature trends in water from selected aquifer wells at the Advanced Test Reactor Complex, Idaho Nuclear Technology and Engineering Center, and the Radioactive Waste Management Complex, Idaho National Laboratory, Idaho.

10. Map showing areal distribution of temperature trends in water from selected perched groundwater wells at the Advanced Test Reactor Complex, Idaho Nuclear Technology and Engineering Center, and the Radioactive Waste Management Complex, Idaho National Laboratory, Idaho 


\section{Figures-Continued}

11. Map showing areal distribution of tritium trends in water from selected aquifer wells at and near the Idaho National Laboratory, Idaho...

12. Map showing areal distribution of tritium trends in water from selected aquifer wells at the Advanced Test Reactor Complex, Idaho Nuclear Technology and Engineering Center, and the Radioactive Waste Management Complex, Idaho National Laboratory, Idaho.

13. Map showing areal distribution of tritium trends in water from selected perched groundwater wells at the Advanced Test Reactor Complex, Idaho Nuclear Technology and Engineering Center, and the Radioactive Waste Management Complex, Idaho National Laboratory, Idaho.

14. Map showing areal distribution of strontium-90 trends in water from selected aquifer wells at and near the Idaho National Laboratory, Idaho.

15. Map showing areal distribution of strontium-90 trends in water from selected aquifer wells at the Advanced Test Reactor Complex, Idaho Nuclear Technology and Engineering Center, and the Radioactive Waste Management Complex, Idaho National Laboratory, Idaho.

16. Map showing areal distribution of strontium-90 trends in water from selected perched groundwater wells at the Advanced Test Reactor Complex, Idaho Nuclear Technology and Engineering Center, and the Radioactive Waste Management Complex, Idaho National Laboratory, Idaho

17. Map showing areal distribution of chloride concentration trends in water from selected aquifer wells at and near the Idaho National Laboratory, Idaho...

18. Map showing areal distribution of chloride concentration trends in water from selected aquifer wells at the Advanced Test Reactor Complex, Idaho Nuclear Technology and Engineering Center, and the Radioactive Waste Management Complex, Idaho National Laboratory, Idaho.

19. Map showing areal distribution of chloride concentration trends in water from selected perched groundwater wells at the Advanced Test Reactor Complex, Idaho Nuclear Technology and Engineering Center, and the Radioactive Waste Management Complex, Idaho National Laboratory, Idaho.

20. Graphs showing fluctuations in chloride, sodium, and sulfate concentrations relative to water-level changes at wells USGS 35 and USGS 39 and changes in streamflow from the Big Lost River, Idaho

21. Map showing areal distribution of sodium concentration trends in water from selected aquifer wells at and near the Idaho National Laboratory, Idaho...

22. Map showing areal distribution of sodium concentration trends in water from selected aquifer wells at the Advanced Test Reactor Complex, Idaho Nuclear Technology and Engineering Center, and the Radioactive Waste Management Complex, Idaho National Laboratory, Idaho.

23. Map showing areal distribution of sodium concentration trends in water from selected perched groundwater wells at the Advanced Test Reactor Complex, Idaho Nuclear Technology and Engineering Center, and the Radioactive Waste Management Complex, Idaho National Laboratory, Idaho.

24. Map showing areal distribution of sulfate concentration trends in water from selected wells at and near the Idaho National Laboratory, Idaho..... 


\section{Figures-Continued}

25. Map showing areal distribution of sulfate concentration trends in water from selected aquifer wells at the Advanced Test Reactor Complex, Idaho Nuclear Technology and Engineering Center, and the Radioactive Waste Management Complex, Idaho National Laboratory, Idaho

26. Map showing areal distribution of sulfate concentration trends in water from selected perched groundwater wells at the Advanced Test Reactor Complex, Idaho Nuclear Technology and Engineering Center, and the Radioactive Waste Management Complex, Idaho National Laboratory, Idaho.

27. Map showing areal distribution of nitrite plus nitrate (as N) concentration trends in water from selected wells at and near the Idaho National Laboratory, Idaho

28. Map showing areal distribution of nitrite plus nitrate (as N) concentration trends in water from selected aquifer wells at the Advanced Test Reactor Complex, Idaho Nuclear Technology and Engineering Center, and the Radioactive Waste Management Complex, Idaho National Laboratory, Idaho

29. Graph showing carbon tetrachloride trend from Radioactive Waste Management Complex Production well, Idaho National Laboratory, Idaho, 2005-12.

\section{Tables}

1. Summary of selected previous investigations on geology, hydrology, and characteristics of groundwater and perched groundwater at and near the Idaho National Laboratory, Idaho, 1961-2013.

2. Site information for wells at and near the Idaho National Laboratory, Idaho.

3. Comparison of trend analyses for selected wells using additional explanatory variables, included as covariates to the trend model, Idaho National Laboratory, Idaho

4. Summary statistics and trend analyses for field measurements of $\mathrm{pH}$, specific conductance, and water temperature for aquifer and perched groundwater wells after installation of dedicated pumps at and near the Idaho National Laboratory, Idaho, 1989-2012.

5. Summary statistics and trend test results for selected radiochemical constituents in water from aquifer and perched groundwater wells at and near the Idaho National Laboratory, Idaho, 1981-2012

6. Summary of water-quality results for selected radiochemical constituents in water from aquifer and perched groundwater wells at and near the Idaho National Laboratory, Idaho

7. Summary statistics and trend test results for selected constituents in water from aquifer and perched groundwater wells at and near the Idaho National Laboratory, Idaho, 1989-2012.

8. Summary statistics and trend test results for volatile organic compounds in water from aquifer wells at and near the Idaho National Laboratory, Idaho, 1987-2012 


\section{Conversion Factors, Datums, and Abbreviations}

\section{Conversion Factors}

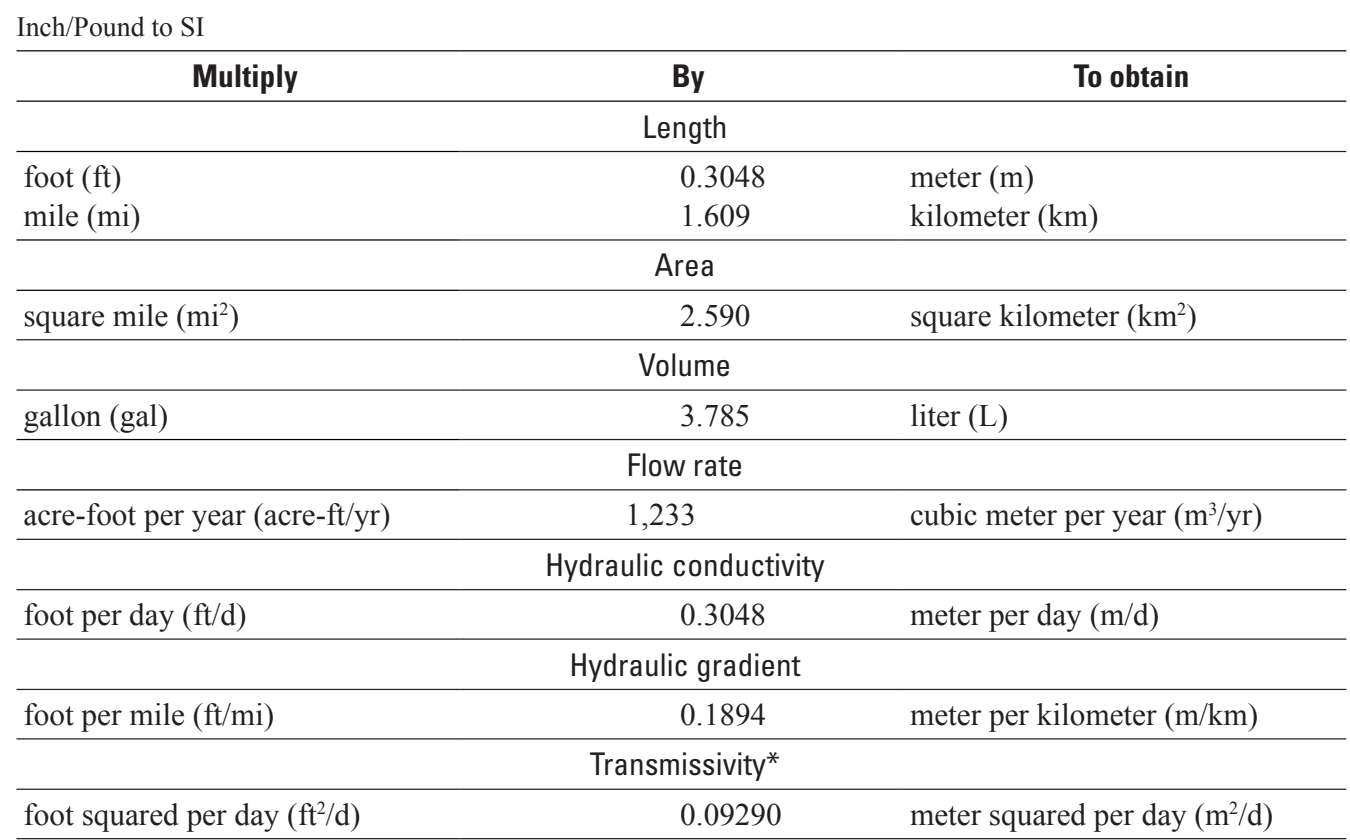

SI to Inch/Pound

\begin{tabular}{lcc}
\hline \multicolumn{1}{c}{ Multiply } & By & To obtain \\
\hline liter $(\mathrm{L})$ & Volume & \\
\hline & 33.82 & ounce, fluid (fl. oz) \\
\hline kilogram $(\mathrm{kg})$ & Mass & \\
\hline & 2.205 & pound avoirdupois $(\mathrm{lb})$ \\
\hline picocurie per liter $(\mathrm{pCi} / \mathrm{L})$ & Radioactivity & \\
\hline
\end{tabular}

Temperature in degrees Celsius $\left({ }^{\circ} \mathrm{C}\right)$ may be converted to degrees Fahrenheit $\left({ }^{\circ} \mathrm{F}\right)$ as follows:

$$
{ }^{\circ} \mathrm{F}=\left(1.8 x^{\circ} \mathrm{C}\right)+32 .
$$

*Transmissivity: The standard unit for transmissivity is cubic foot per day per square foot times foot of aquifer thickness $\left[\left(\mathrm{ft}^{3} / \mathrm{d}\right) / \mathrm{ft}^{2}\right] \mathrm{ft}$. In this report, the mathematically reduced form, foot squared per day $\left(\mathrm{ft}^{2} / \mathrm{d}\right)$, is used for convenience.

Specific conductance is given in microsiemens per centimeter at 25 degrees Celsius $(\mu \mathrm{S} / \mathrm{cm}$ at $\left.25^{\circ} \mathrm{C}\right)$.

Concentrations of chemical constituents in water are given either in milligrams per liter (mg/L) or micrograms per liter $(\mu \mathrm{g} / \mathrm{L})$. 


\section{Conversion Factors, Datums, and Abbreviations-Continued}

\section{Datums}

Vertical coordinate information is referenced to the National Geodetic Vertical Datum of 1929 (NGVD 29).

Horizontal coordinate information is referenced to the North American Datum of 1927 (NAD 27). Altitude, as used in this report, refers to distance above the vertical datum.

$\begin{array}{ll}\text { Abbreviations } & \\ \text { AFT } & \text { accelerated failure time } \\ \text { ATR Complex } & \begin{array}{l}\text { Advanced Test Reactor Complex (formerly RTC, Reactor Technology } \\ \text { Complex, and TRA, Test Reactor Area) }\end{array} \\ \text { BLS } & \text { below land surface } \\ \text { CFA } & \text { Central Facilities Area } \\ \text { CFC } & \text { chlorofluorocarbon } \\ \text { CRAN } & \text { Comprehensive R Active Network } \\ \text { DOE } & \text { U.S. Department of Energy } \\ \text { ESRP } & \text { eastern Snake River Plain } \\ \text { E-value } & \text { estimated value } \\ \text { INEL } & \text { Idaho National Engineering Laboratory (1974-97) } \\ \text { INL } & \text { Idaho National Laboratory } \\ \text { INTEC } & \text { Idaho Nuclear Technology and Engineering Center } \\ \text { IRL } & \text { interim reporting level } \\ \text { LRL } & \text { laboratory reporting level } \\ \text { LT-MDL } & \text { long-term method detection level } \\ \text { MCL } & \text { maximum contaminant level } \\ \text { MLE } & \text { maximum-likelihood estimation } \\ \text { NRF } & \text { Naval Reactors Facility } \\ \text { NWIS } & \text { National Water Information System } \\ \text { NWOL } & \text { National Water Ouality Laboratory (USGS) } \\ \text { PBF } & \text { Power Burst Facility } \\ \text { RESL } & \text { Radiological and Environmental Sciences Laboratory (DOE) } \\ \text { OA } & \text { quality assurance } \\ \text { OC } & \text { quality control } \\ \text { RWMC } & \text { Radioactive Waste Management Complex } \\ S & \text { sample standard deviation } \\ \text { SDA } & \text { Subsurface Disposal Area } \\ \text { TAN } & \text { U.S. Geological Survey } \\ \text { TOC } & \text { volatile organic compound } \\ \text { USGS } & \\ \text { VOC } & \end{array}$




\title{
Water-Quality Characteristics and Trends for Selected Wells Possibly Influenced by Wastewater Disposal at the Idaho National Laboratory, Idaho, 1981-2012
}

\author{
By Linda C. Davis, Roy C. Bartholomay, Jason C. Fisher, and Neil V. Maimer
}

\begin{abstract}
The U.S. Geological Survey, in cooperation with the U.S. Department of Energy, analyzed water-quality data collected from 64 aquifer wells and 35 perched groundwater wells at the Idaho National Laboratory (INL) from 1981 through 2012. The wells selected for the study were wells that possibly were affected by wastewater disposal at the INL. The data analyzed included tritium, strontium-90, major cations, anions, nutrients, trace elements, total organic carbon, and volatile organic compounds. The analyses were performed to examine water-quality trends that might influence future management decisions about the number of wells to sample at the INL and the type of constituents to monitor.

The data were processed using custom computer scripts developed in the R programming language. Summary statistics were calculated for the datasets. Water-quality trends were determined using a parametric survival regression model to fit the observed data, including left-censored, interval-censored, and uncensored data. The null hypothesis of the trend test was that no relation existed between time and concentration; the alternate hypothesis was that time and concentration were related through the regression equation. A significance level of 0.05 was selected to determine if the trend was statistically significant.

Trend test results for tritium and strontium-90 concentrations in aquifer wells indicated that nearly all wells had decreasing or no trends. Similarly, trends in perched groundwater wells were mostly decreasing or no trends; trends were increasing in two perched groundwater wells near the Advanced Test Reactor Complex. Decreasing trends generally are attributed to lack of recent wastewater disposal and radioactive decay.

Trend test results for chloride, sodium, sulfate, nitrite plus nitrate (as nitrogen), chromium, trace elements, and total organic carbon concentrations in aquifer wells indicated that most wells had either decreasing or no trends. The decreasing trends in these constituents are attributed to decrease in disposal of these constituents, as well as discontinued use of the old percolation ponds south of the Idaho Nuclear
\end{abstract}

Technology and Engineering Center (INTEC) and redirection of wastewater to the new percolation ponds 2 miles southwest of the INTEC in 2002.

Chloride (along with sodium, sulfate, and some nitrate) concentrations in wells south of the INTEC may be influenced by episodic recharge from the Big Lost River. These constituent concentrations decrease during wetter periods when there is probably more recharge from the Big Lost River and increase during dry periods, when there is less recharge.

Some wells downgradient of the Central Facilities Area and near the southern boundary of the INL showed increasing trends in sodium concentration, whereas there was no trend in chloride. The increasing trend for sodium could be due to the long term influence of wastewater disposal from upgradient facilities and the lack of trend for chloride could be because chloride is more mobile than sodium and more dispersed in the aquifer system.

Volatile organic compound concentration trends were analyzed for nine aquifer wells. Trend test results indicated an increasing trend for carbon tetrachloride for the Radioactive Waste Management Complex Production Well for the period 1987-2012; however, trend analyses of data collected since 2005 show no statistically significant trend indicating that engineering practices designed to reduce movement of volatile organic compounds to the aquifer may be having a positive effect on the aquifer.

\section{Introduction}

The Idaho National Laboratory (INL), operated by the U.S. Department of Energy (DOE), encompasses about $890 \mathrm{mi}^{2}$ of the eastern Snake River Plain (ESRP) in southeastern Idaho (fig. 1). The INL was established in 1949 to develop atomic energy, nuclear safety research, defense programs, environmental research, and advanced energy concepts. Wastewater disposal sites at the Test Area North (TAN), the Naval Reactors Facility (NRF), the Advanced Test Reactor Complex (ATR Complex), and the Idaho Nuclear Technology and Engineering Center (INTEC) (fig. 1) have 
contributed radioactive- and chemical-waste contaminants to the ESRP aquifer. These sites incorporated various wastewater disposal methods, including lined evaporation ponds, unlined percolation (infiltration) ponds and ditches, drain fields, and injection wells. Waste materials buried in shallow pits and trenches within the Subsurface Disposal Area (SDA) at the Radioactive Waste Management Complex (RWMC) also have contributed contaminants to groundwater.

Since 1949, the U.S. Geological Survey (USGS) has worked in cooperation with the DOE at the INL to define: (1) the quality and availability of water for human consumption, (2) the usability of the water for supporting construction and cooling of facilities and for diluting concentrated waste streams, (3) the location and movement of contaminants in the ESRP aquifer and perched groundwater zones, (4) the sources of recharge to the aquifer, (5) an early detection network for contaminants moving past the INL boundaries, and (6) the processes controlling the origin and distribution of contaminants and naturally occurring constituents in the aquifer (Ackerman and others, 2010).

Since its inception, this water-quality monitoring program at the INL has included a network that once numbered as many as 200 wells. The network of wells has been sampled over the years for tritium, strontium-90, iodine-129, cesium-137, plutonium-238, plutonium-239, -240 (undivided), americium-241, gross alpha- and gross beta-radioactivity, sodium, bromide, chloride, fluoride, sulfate, nitrate, chromium and other trace elements, volatile organic compounds (VOCs), and total organic carbon (TOC) (Bartholomay, 2013; Davis and others 2013). Most wells in this network were constructed as open boreholes, and many are open to the aquifer throughout their entire depth below the water table.

\section{Purpose and Scope}

This report presents an analysis of water-quality characteristics and trends for groundwater samples collected from selected wells that possibly are affected by wastewater disposal at and near the INL. Water-quality trends were examined to aid future management decisions regarding the number of wells to sample at the INL and the type of constituents to monitor. The criteria for selecting the sampling sites analyzed in this report were: (1) that at least 10 years of data were available for each site, and (2) that the sites represented water in a location that probably was affected by INL wastewater disposal.

Water samples collected from 64 aquifer wells and 35 perched groundwater wells were analyzed for selected constituents. The constituents include some combination of tritium, strontium-90, cesium-137, plutonium-238, plutonium-239, -240 (undivided), americium-241, gross alpha- and beta-particle radioactivity, calcium, magnesium, potassium, silica, sodium, bromide, chloride, fluoride, sulfate, nitrate (as N), orthophosphate (as P), chromium and other trace elements, and TOC. Constituent concentrations were plotted against time to evaluate the data; additional trend analyses were completed using the $\mathrm{R}$ programming language "Trends" package (Fisher and Davis, 2014; appendix A), which incorporates a parametric survival regression model that is fit to the observed data, including left-censored (values reported as less than a laboratory reporting level [LRL]), interval-censored (values with an associated uncertainty), and uncensored data. Summary statistics were also calculated for the datasets.

\section{Geohydrologic Setting}

The INL is located on the west-central part of the ESRP. The ESRP is a northeast-trending structural basin about $200 \mathrm{mi}$ long and 50-70 mi wide (fig. 1). The basin has been filled with basaltic lava flows interbedded with terrestrial sediments. The basaltic rocks and sedimentary deposits combine to form the ESRP aquifer, which is the primary source of groundwater for the ESRP.

The ESRP aquifer is one of the most productive aquifers in the United States (U.S. Geological Survey, 1985, p. 193). Groundwater generally moves from northeast to southwest and discharges to springs along the Snake River downstream of Twin Falls, Idaho, about 100 mi southwest of the INL (fig. 1). Groundwater moves horizontally through basalt interflow zones and vertically through joints and interfingering edges of basalt flows. Infiltration of surface water, heavy pumpage, geohydrologic conditions, and seasonal fluxes of recharge and discharge locally affect the movement of groundwater (Garabedian, 1986). The ESRP aquifer is recharged primarily from infiltration of applied irrigation water, infiltration of streamflow, groundwater inflow from adjoining mountain drainage basins, and infiltration of precipitation (Ackerman and others, 2006).

At the INL, depth to water in wells completed in the ESRP aquifer ranges from about $200 \mathrm{ft}$ below land surface in the northern part of the INL to more than $900 \mathrm{ft}$ below land surface in the southeastern part of the INL. A significant proportion of the groundwater moves through the upper 200-800 ft of basaltic rock (Mann, 1986, p. 21). Ackerman (1991a, p. 30) and Bartholomay and others (1997, table 3) reported transmissivity values for basalt in the upper part of the aquifer ranging from 1.1 to $760,000 \mathrm{ft}^{2} / \mathrm{d}$. The hydraulic gradient at the INL ranges from 2 to $10 \mathrm{ft} / \mathrm{mi}$, with an average of $4 \mathrm{ft} / \mathrm{mi}$ (Davis and others, 2013, fig. 9). Horizontal flow velocities of 2 to $26 \mathrm{ft} / \mathrm{d}$ have been calculated based on the movement of various constituents in different areas of the aquifer at and near the INL (Robertson and others, 1974; Mann and Beasley, 1994; Cecil and others, 2000; Plummer and others, 2000; and Busenberg and others, 2001). 

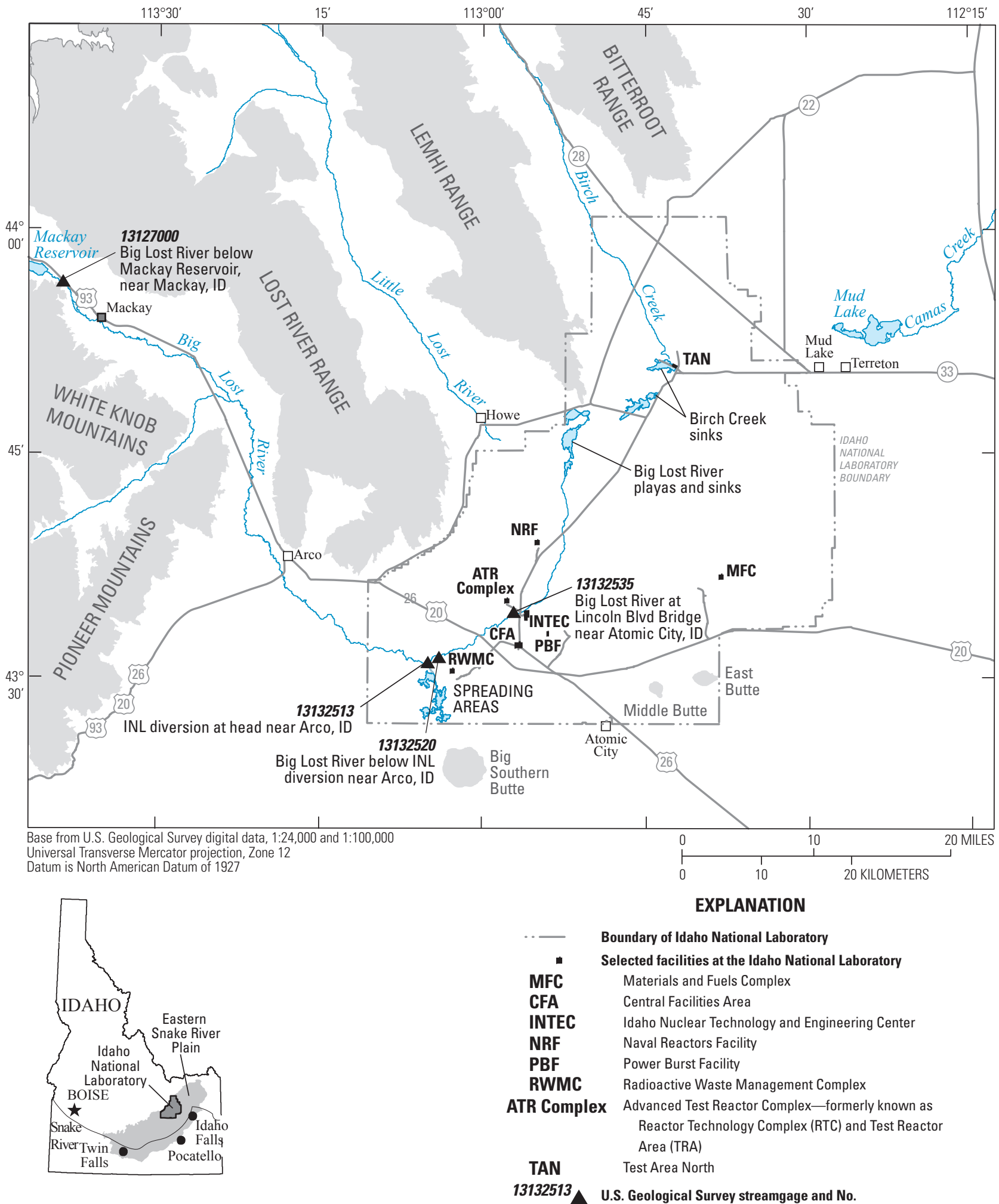

Figure 1. Locations of selected facilities at the Idaho National Laboratory, Idaho. 
These flow rates equate to a travel time of about $50-700$ years for water beneath the INL to travel to springs that discharge at the terminus of the ESRP groundwater- flow system near Twin Falls, Idaho. Localized tracer tests at the INL have shown that vertical- and horizontal-transport rates are as high as 60-150 ft/d (Nimmo and others, 2002; Duke and others, 2007).

Olmsted (1962), Robertson and others (1974), and Busenberg and others (2001) classified groundwater at the INL based on chemical types derived from dissolution of the rocks and minerals within the recharge source areas. Olmsted's type A water consisted of calcium and magnesium concentrations that constituted at least 85 percent of the cations and bicarbonate that constituted at least 70 percent of the anions. Type A water is present in the central and western part of the INL. Type A water is attributed to seepage loss from the Big Lost River and from groundwater underflow from the Big Lost River, Little Lost River, and Birch Creek drainage basins to the west and northwest of the INL (fig. 1) that contain alluvium derived from Paleozoic carbonate rocks from the surrounding mountains.

Olmsted's type B water, which is characterized by higher equivalent fractions of sodium, potassium, fluoride, and silica than type A water, underlies much of the eastern part of the INL and is often referred to as regional water. The groundwater originates from the area northeast of the INL that is composed of a much higher fraction of rhyolitic and andesitic volcanic rocks than mountains west and northwest of the INL that contribute to Type A water. Busenberg and others (2001) used age dating techniques of chlorofluorocarbons (CFCs), sulfur hexafluoride, and tritium/helium to further classify the regional water at the INL into two types based on the recharge type of the young fraction of groundwater. Water in the southeastern part of the INL represented a binary mixture of old (water greater than 40 to 55 years old that did not contain tritium or CFCs, respectively) regional groundwater underflow with young water derived from rapid, focused recharge, probably from precipitation infiltration. Water in the northeastern part of the INL is old, regional groundwater underflow that is mixed with local rapid, focused recharge; slow, diffuse areal recharge through the unsaturated zone; and agricultural return flow from the Mud Lake and Terreton areas (fig. 1).

Disposal of wastewater to infiltration ponds and infiltration of surface water at waste-burial sites at the INL has resulted in the formation of perched groundwater in basalts and in sedimentary interbeds that overlie the ESRP aquifer (Cecil and others, 1991). Perched groundwater has formed in a complex sequence of basalt flow and sedimentary interbeds beneath the ATR Complex, the INTEC, and the RWMC. Perched groundwater also has been detected beneath infiltration ponds and ditches at other facilities at the INL in the past, but is not discussed in this report.

Anderson and Lewis (1989) and Anderson (1991) correlated geophysical logs to describe the stratigraphic sequences in which perched groundwater has formed at the ATR Complex, INTEC, and the RWMC. Although the subsurface stratigraphy, geohydrologic characteristics, and waste disposal practices at each of these areas differs, the features controlling the formation of perched groundwater at these sites are similar (Cecil and others, 1991). Sedimentary interbeds in the subsurface may have smaller vertical hydraulic conductivities than overlying basalt flows, and alteration between basalt flows may contribute to reduced vertical hydraulic conductivity in the interflow rubble zones (Perkins and Winfield, 2007). Dense, unfractured basalt flows may have a decreased vertical hydraulic conductivity and inhibited downward flow, and sedimentary or chemical infilling of fractures in basalt may decrease vertical hydraulic conductivity by limiting the interconnectivity of fractures that reduce the water transmitting capability of the basalts (Cecil and others, 1991). Any combination of these factors may disrupt the downward vertical movement of water and contribute to the formation of perched groundwater zones.

At the ATR Complex, deep and shallow perched groundwater zones have formed as a result of disposal of wastewater to infiltration ponds (Tucker and Orr, 1998). South of the INTEC, perched groundwater zones formed previously because of wastewater disposal to the old percolation ponds, but the zones have dried up since the ponds were taken out of service in 2002. Perched groundwater also has been detected in other areas at the INTEC and may be attributed to leaking pipelines, leach fields, damaged casing in the upper part of the INTEC disposal well, other infiltration ponds, or landscape irrigation (Tucker and Orr, 1998). Perched groundwater also is present below the new percolation ponds that were put into service during 2002. Perched groundwater beneath the RWMC formed from infiltration of snowmelt and rain and recharge from the Big Lost River and INL spreading areas. This perched groundwater contains constituents leached from buried radioactive and organic-chemical wastes. Perched groundwater beneath wastewater infiltration ponds and buried waste is an integral part of the pathway for waste-constituent migration to the ESRP aquifer. The extent of perched groundwater is affected by the waste-disposal practices.

\section{Previous Investigations}

Hydrologic conditions and the distribution of selected wastewater constituents in groundwater and perched groundwater are discussed in a series of reports describing the INL. Table 1 summarizes selected previous investigations of the geology, hydrology, and characteristics of groundwater and perched water at and near the INL, specifies the periods covered by some of those investigations, and lists report citations. Full references for these citations are available in the section, "References Cited." Numerous previous investigations on the hydrology and geology at the INL have been done by INL contractors, state agencies, and the USGS. The USGS provides a list of references and hyperlinks to published reports from its previous INL studies at the USGS INL Project Office Web site at http://id.water.usgs.gov/projects/INL/index. html. 
Table 1. Summary of selected previous investigations on geology, hydrology, and characteristics of groundwater and perched groundwater at and near the Idaho National Laboratory, Idaho, 1961-2013.

[Abbreviations: NRTS, National Reactor Testing Station; RWMC, Radioactive Waste Management Complex; INEL, Idaho National Engineering Laboratory; INEEL, Idaho National Engineering and Environmental Laboratory; INL, Idaho National Laboratory; ATR Complex, Advanced Test Reactor Complex (formerly the TRA, Test Reactor Area and the RTC, Reactor Technology Complex); INTEC, Idaho Nuclear Technology and Engineering Center (formerly the ICPP, Idaho Chemical Processing Plant); NA, not applicable]

\begin{tabular}{|c|}
\hline Reference \\
\hline Olmsted (1962) \\
\hline Morris and others $(1963,1964,1965)$ \\
\hline Barraclough and others (1967a) \\
\hline Barraclough and others (1967b) \\
\hline Nace and others (1975) \\
\hline Robertson and others (1974) \\
\hline Barraclough and others (1976) \\
\hline Barracough and Jenson (1976) \\
\hline Barraclough and others (1981) \\
\hline Lewis and Jensen (1985) \\
\hline $\begin{array}{l}\text { Pittman and others (1988) } \\
\text { http://pubs.er.usgs.gov/publication/wri894008 }\end{array}$ \\
\hline $\begin{array}{l}\text { Orr and Cecil (1991) } \\
\text { http://pubs.er.usgs.gov/publication/wri914047 }\end{array}$ \\
\hline Ackerman (1991a) \\
\hline Bartholomay and others (1995) \\
\hline $\begin{array}{l}\text { Bartholomay and others (1997) } \\
\text { http://pubs.er.usgs.gov/publication/wri974086 }\end{array}$ \\
\hline $\begin{array}{l}\text { Bartholomay and others (2000) } \\
\text { http://pubs.er.usgs.gov/publication/wri004192 }\end{array}$ \\
\hline $\begin{array}{l}\text { Davis (2006b) } \\
\text { http://pubs.er.usgs.gov/publication/sir20065088 }\end{array}$ \\
\hline $\begin{array}{l}\text { Ackerman and others (2006) } \\
\text { http://pubs.er.usgs.gov/publication/sir20065122 }\end{array}$ \\
\hline $\begin{array}{l}\text { Davis (2008) } \\
\text { http://pubs.er.usgs.gov/publication/sir20085089 }\end{array}$ \\
\hline $\begin{array}{l}\text { Davis (2010) } \\
\text { http://pubs.er.usgs.gov/publication/sir20105197 }\end{array}$ \\
\hline
\end{tabular}

Ackerman and others (2010)

Bartholomay and others (2012)

http://pubs.er.usgs.gov/publication/sir20125169

Fisher and others (2012)

Davis and others (2013)

Investigation
period Summary

Groundwater

NA Chemical and physical character of groundwater at the NRTS, Idaho

NA Hydrology of waste disposal at the NRTS, Idaho

1965 Hydrology of the NRTS, Idaho

1966 Hydrology of the NRTS, Idaho

NA Generalized geologic framework of the NRTS, Idaho

NA Effects of waste disposal on the geochemistry of groundwater at the NRTS, Idaho

NA Hydrology of the solid waste burial ground (now the RWMC)

1971-73 Hydrologic data for the Idaho INEL, Idaho

1974-78 Hydrologic conditions for the INEL, Idaho

1979-81 Hydrologic conditions for the INEL, Idaho

1982-85 Hydrologic conditions for the INEL, Idaho

1986-88 Hydrologic conditions and distribution of selected chemical constituents in water at the INEL, Idaho

NA Analyzed data from 183 aquifer tests conducted in 94 wells to estimate transmissivity of basalts and sedimentary interbeds containing groundwater beneath the INL

1989-91 Hydrologic conditions and distribution of selected radiochemical and chemical constituents in water, INEL, Idaho

1992-95 Hydrologic conditions and distribution of selected radiochemical and chemical constituents in water, INEL, Idaho

1996-98 Hydrologic conditions and distribution of selected constituents in water, INEEL, Idaho

1999-2001 Hydrologic conditions and distribution of selected radiochemical and chemical constituents in water, INL, Idaho

NA Conceptual model of groundwater flow in the eastern Snake River Plain aquifer, INL, with implications for contaminant transport

2002-05 Hydrologic conditions and distribution of selected radiochemical and chemical constituents in groundwater and perched groundwater, INL, Idaho

2006-08 Hydrologic conditions and distribution of selected radiochemical and chemical constituents in groundwater and perched groundwater, INL, Idaho.

NA Steady-state and transient models of groundwater flow and advective transport in the eastern Snake River Plain aquifer at the INL.

1949-2009 Water-quality characteristics and trends for selected sites at and near the INL, Idaho

NA Comparison of 3-dimensional model estimates of groundwater source areas and velocities to independently derived estimates at INL

2009-11 Hydrologic conditions and distribution of selected radiochemical and chemical constituents in groundwater and perched groundwater, INL, Idaho 
Table 1. Summary of selected previous investigations on geology, hydrology, and characteristics of groundwater and perched groundwater at and near the Idaho National Laboratory, Idaho, 1961-2013.-Continued

[Abbreviations: NRTS, National Reactor Testing Station; RWMC, Radioactive Waste Management Complex; INEL, Idaho National Engineering Laboratory; INEEL, Idaho National Engineering and Environmental Laboratory; INL, Idaho National Laboratory; ATR Complex, Advanced Test Reactor Complex (formerly the TRA, Test Reactor Area and the RTC, Reactor Technology Complex); INTEC, Idaho Nuclear Technology and Engineering Center (formerly the ICPP, Idaho Chemical Processing Plant); na, not applicable]

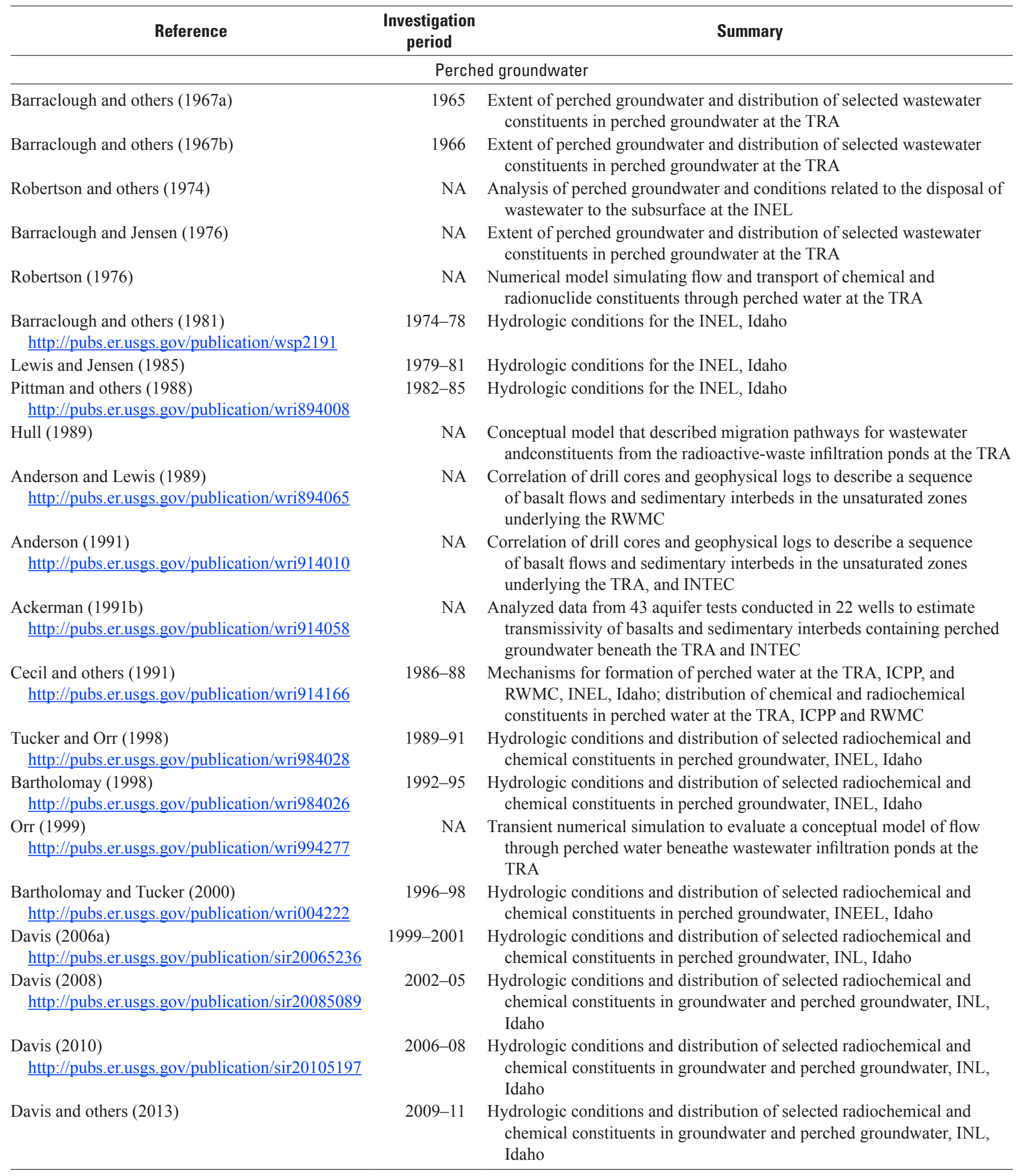


Some qualitative information about trends of selected constituents for selected wells is given in the more recent hydrologic conditions reports listed in table 1 , and trend data are given in Davis and others (2013) for wastewater constituents in water from several wells that are affected by wastewater disposal. Trends for most of the constituents plotted show decreasing concentrations because of the changes in the methods of disposal, dilution, and dispersion in the aquifer, and reductions of amounts of constituents being discharged. One exception is increasing trends in carbon tetrachloride concentration in two wells at the RWMC (Davis and others, 2013, fig. 29).

Knobel (2006) plotted water-quality data from 1990 through 2003 for 30 wells downgradient of the INTEC to visually compare historical water-quality data collected after purging three well volumes with water-quality data collected after purging one well volume. Qualitative and quantitative evaluations indicated that the water-quality data were comparable for the different purge volumes for the 30 wells studied.

Concentration trends for selected wells not affected by wastewater disposal at the INL are given for iron, zinc, and nitrate in U.S. Department of Energy (2010). That study indicated that the use of galvanized pipes in some of the wells probably is responsible for elevated zinc concentrations. Nitrate concentrations were plotted for wells USGS 2, 100, and 101, and the increasing trends were attributed to long-term agricultural practices northeast of the INL.

Neher and others (1998) plotted water-quality data collected by the USGS from 1960 through 1995 for 66 wells near facilities at the INL and wells near the southern boundary of the INL to assist the scientific community in identifying issues that may require additional investigation and to provide a reference document for individuals interested in the water quality of the ESRP aquifer near the INL. Radionuclide data and inorganic chemicals that were commonly disposed at the INL and specific conductance measurements also were plotted by Neher and others (1998).

Bartholomay and others (2012) used statistical methods to determine trends for selected constituents for 67 wells and 7 surface-water sites sampled by the USGS at the INL that probably were not affected by wastewater disposal at the INL. They determined that chloride trends in wells influenced by recharge from the Big Lost River either decreased or had variable increases and decreases due to wet and dry cycles of precipitation and runoff. Wells influenced by regional recharge showed increasing trends for chloride, sodium, sulfate, and nitrate and the increases were attributed to agricultural or other anthropogenic influences upgradient of the INL. Some wells near the NRF and Power Burst Facility (PBF) showed increasing trends possibly due to wastewater disposal at those facilities.

\section{Methods}

\section{Sample Collection and Analyses}

Water samples analyzed for this study were collected from 64 ESRP aquifer wells (figs. 2 and $\underline{3}$ ) and 35 perched groundwater wells (fig. 4). Since 1989, water samples have been analyzed for chemical constituents at the USGS National Water Quality Laboratory (NWQL) in Lakewood, Colorado. Prior to 1989 , water samples were analyzed by various laboratories for chloride, chromium, sodium, and nitrate (Wegner, 1989). Water samples have been analyzed for radiochemical constituents at the DOE Radiological and Environmental Sciences Laboratory (RESL) at the INL since samples were first collected. Many of the samples collected in the 1950s, 1960s, and 1970s were collected during or immediately after cable-drilling, and there was a high probability that some of the samples contained impurities introduced by the drilling (Robertson and others, 1974, appendix B). Some chemical and radiochemical analyses for special studies have been done at the NWQL and by contract laboratories throughout the history of the USGS monitoring program at the INL, but those data were not considered for statistical trend analysis in this study because of the variability of method detection levels and the analytical methods used. Until 2008, the RESL reported an uncertainty of $2 \boldsymbol{s}$, where $\boldsymbol{s}$ is the sample standard deviation, for water samples analyzed for radionuclides, and data were entered into the USGS National Water Information System (NWIS) database with that uncertainty. In 2008, the RESL began reporting the uncertainty as $1 s$, and data are now entered into NWIS with the $1 s$ uncertainty. Analytical uncertainties in this report are reported as $1 \boldsymbol{s}$ for consistency.

Methods used to sample and analyze for selected constituents generally follow the guidelines established by the USGS (Goerlitz and Brown, 1972; Stevens and others, 1975; Wood, 1976; Thatcher and others, 1977; Claassen, 1982; Wershaw and others, 1987; Fishman and Friedman, 1989; Faires, 1993; Fishman, 1993; and U.S. Geological Survey, variously dated). Water samples were collected according to a quality-assurance plan for water-quality activities conducted by personnel at the USGS INL Project Office. The plan was finalized in June 1989 and revised in March 1992, in 1996 (Mann, 1996), in 2003 (Bartholomay and others, 2003), in 2008 (Knobel and others, 2008), and in 2014 (Bartholomay and others, 2014). The plan is available for inspection at the USGS INL Project Office.

Field processing of water samples differed depending on the constituents for which analyses were requested and the time period in which they were collected. 


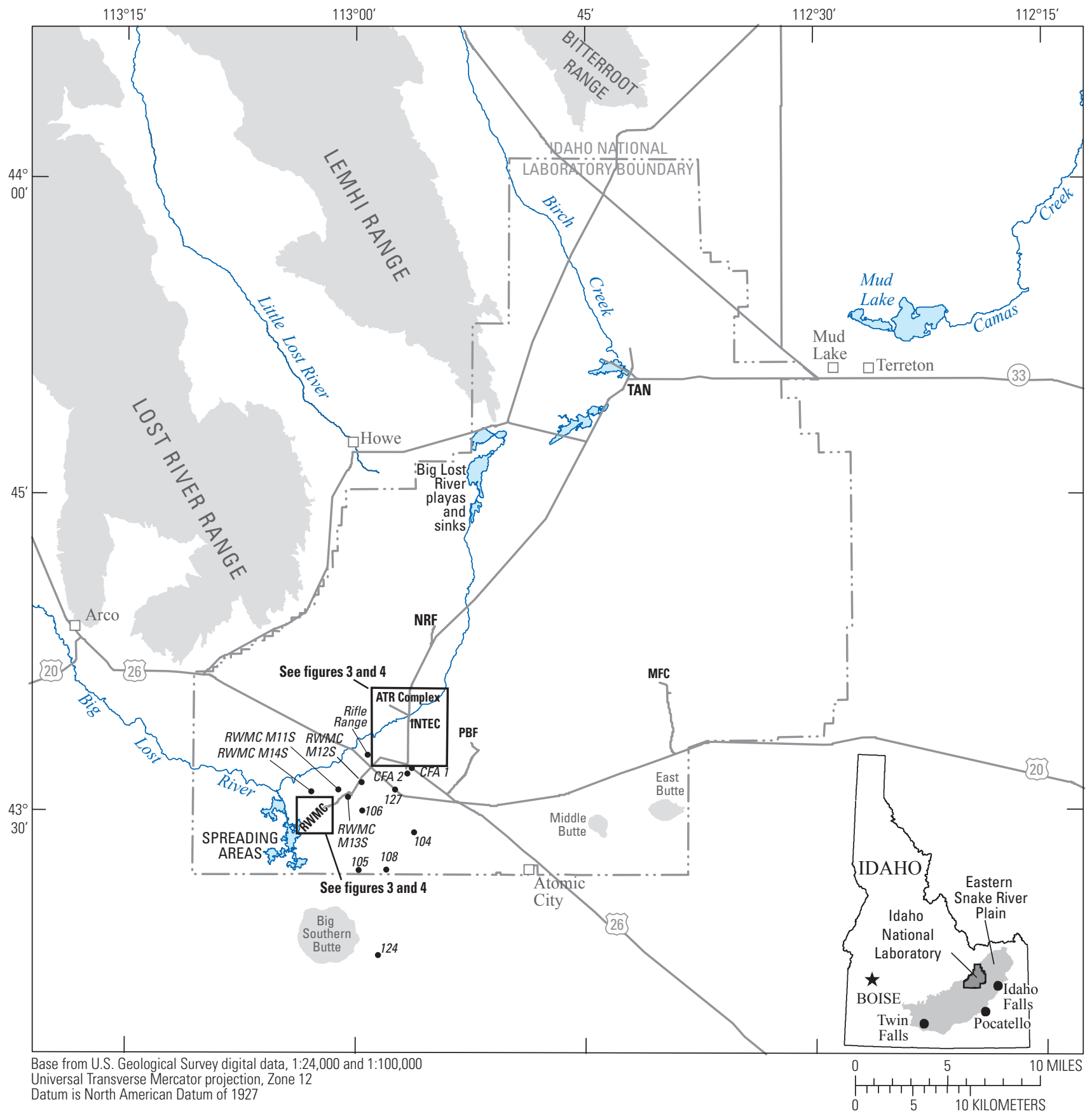

\section{EXPLANATION}

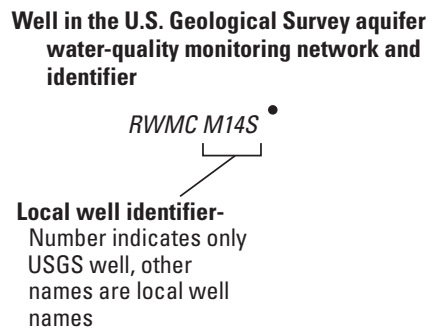

Inset areas for selected facilities at the Idaho National Laboratory-See figure 3 and 4.

RWMC Radioactive Waste Management Complex

ATR Complex Advanced Test Reactor Complex

INTEC Idaho Nuclear Technology and Engineering Center

MFC Materials and Fuels Complex

NRF Naval Reactors Facility

Power Burst Facility

names are local well

Figure 2. Locations of wells in the eastern Snake River Plain aquifer at and near the Idaho National Laboratory, Idaho. 


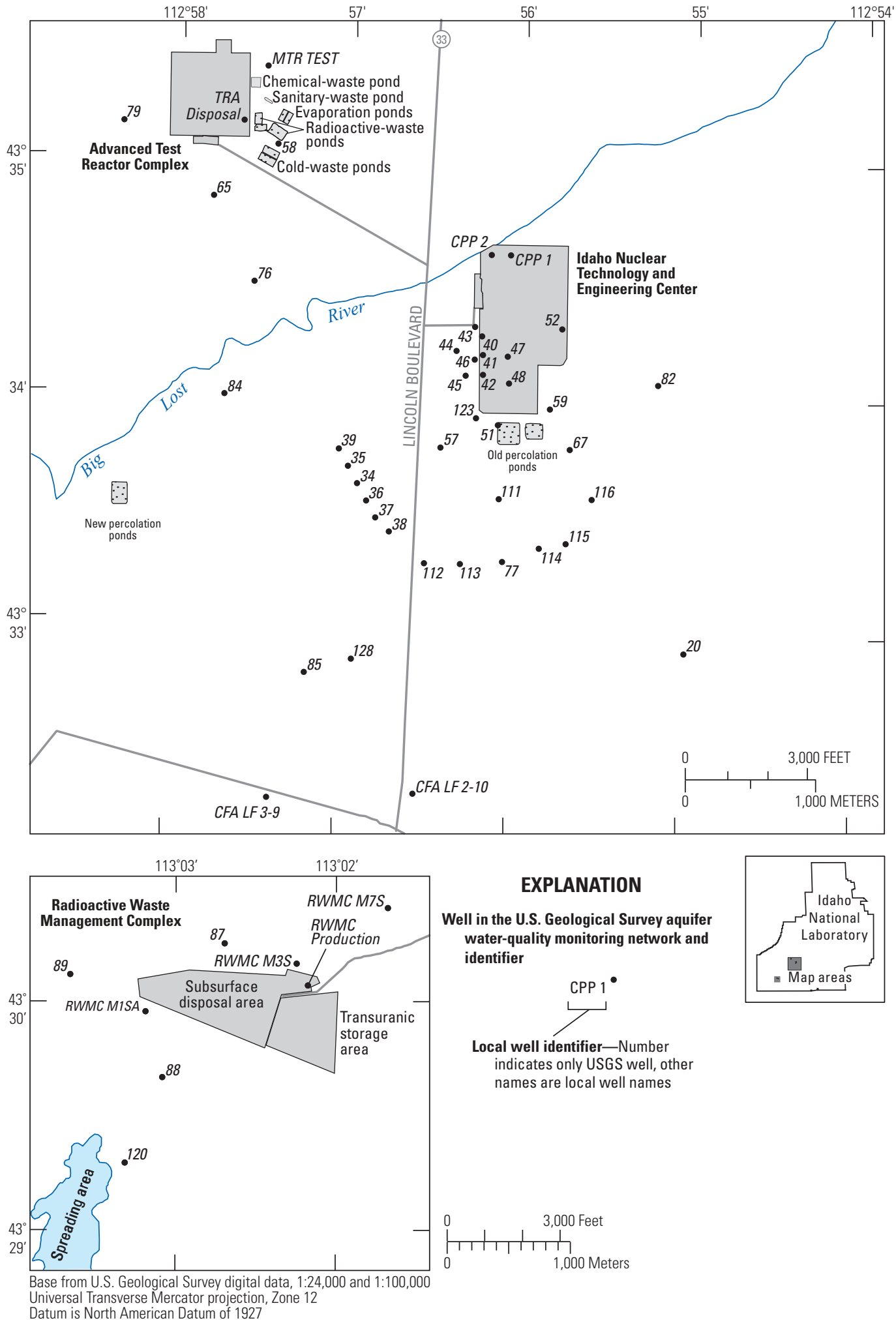

Figure 3. Locations of wells in the eastern Snake River Plain aquifer at and near the Advanced Test Reactor Complex, the Idaho Nuclear Technology and Engineering Center, and the Radioactive Waste Management Complex, Idaho National Laboratory, Idaho. 


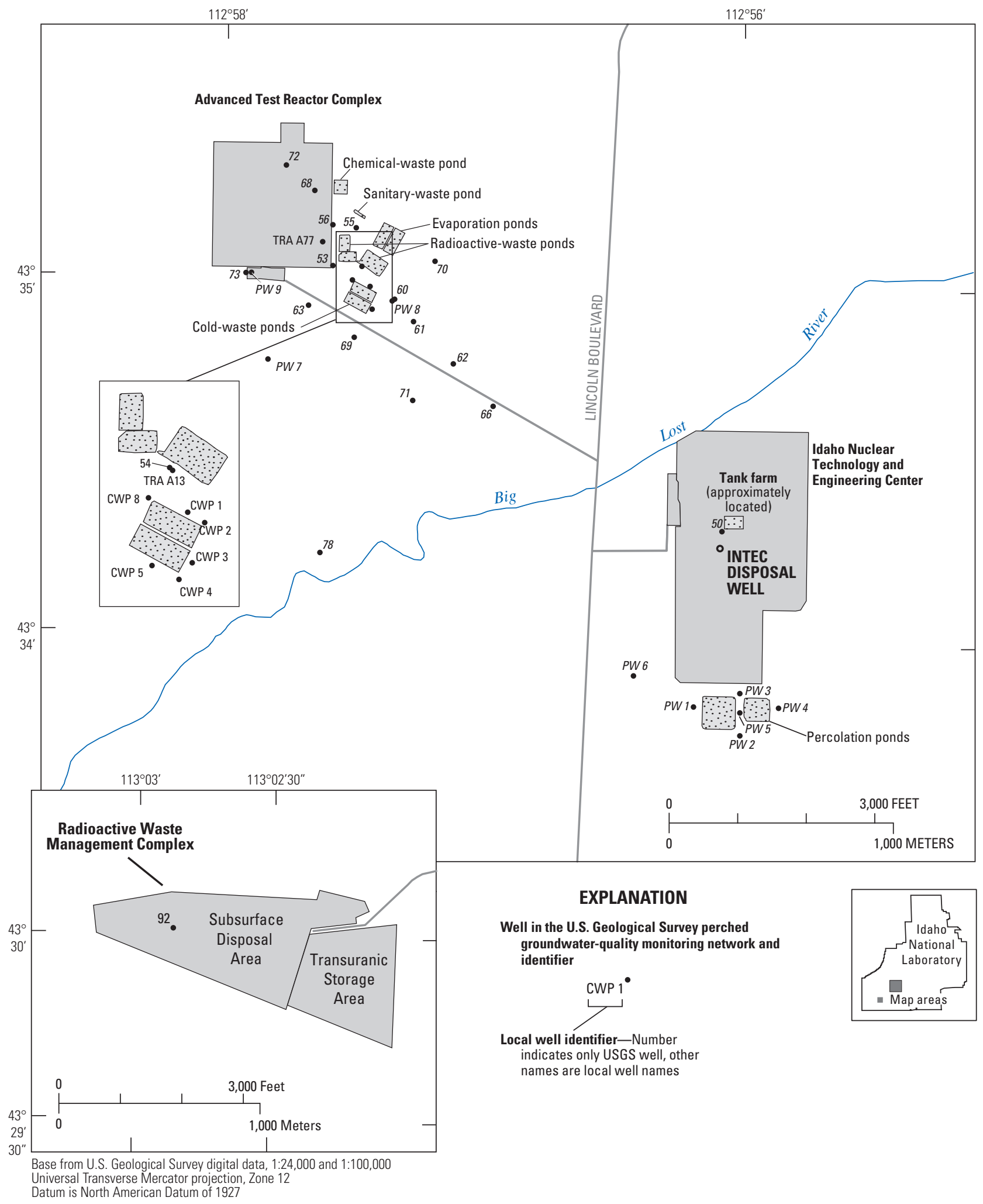

Figure 4. Locations of perched groundwater wells at and near the Advanced Test Reactor Complex, the Idaho Nuclear Technology and Engineering Center, and the Radioactive Waste Management Complex, Idaho National Laboratory, Idaho. 
Water samples analyzed by the NWQL were placed in containers and preserved in accordance with laboratory requirements specified by Timme (1995) and Knobel and others (2008, appendix A). Containers and preservatives for samples collected since 1989 were supplied by the NWQL and were processed using a rigorous quality-control procedure (Pritt, 1989, p. 75) to minimize sample contamination. Water samples requiring filtration were filtered through disposable $0.45-\mu \mathrm{m}$ plate filters or cartridge filters that were pre-rinsed depending on the sample protocol at the time of collection. Water samples analyzed by the RESL were placed in containers and preserved in accordance with laboratory requirements specified by Bodnar and Percival (1982), U.S. Department of Energy (1995), and Knobel and others (2008, appendix A).

Sample collection methods varied for several of the wells during the history of sampling. Permanent pumps were installed at various dates (table 2), with most installations occurring between 1985 and the early 1990s. Prior to installation of pumps, wells were sampled using a portable thief sampler. Some of the samples collected with thief samplers were collected at different depths in the aquifer during the same sampling period. When the depths at which thief samples were collected were known, the data from the depth similar to the depth setting of the current pump were used in the analyses. After pumps were installed, wells were purged for at least three well volumes prior to sample collection until October 2003, when procedures were changed to allow sample collection after one well volume was purged and readings were stable for water temperature, $\mathrm{pH}$, and specific conductance. Studies by Bartholomay (1993) and Knobel (2006) indicated that different purge rates used at the INL did not affect the analytical results for the wells analyzed in the respective studies.

The methods used to preserve samples collected for nutrient analyses also changed over time. Until October 1994, samples collected for nutrients were analyzed at the NWQL and preserved with mercuric chloride and chilling. After October 1994, samples were preserved only by chilling. Bartholomay and Williams (1996) compared preservation methods, and their results indicated that data were comparable between the two methods.

Sample collection frequency varied for all sites used in this study. Since 2003, all sites have been sampled annually, but prior to that timeframe, wells were sampled annually, semi-annually, quarterly, or more frequently depending on the purpose of the sampling program. Some gaps in data occur when pumps were out for repair, samples were lost, or program changes did not call for sampling of the constituent in question.

\section{Quality Assurance/Quality Control}

Beginning in 1980, about 10 percent of water samples were collected for quality assurance (QA) purposes. Quality control (QC) water samples collected by the USGS INL
Project Office generally include equipment blanks, splits, and replicates; however, other types of QC samples also have been collected throughout the history of the program. Comparative studies to determine agreement between analytical results for water-sample pairs by laboratories used by the INL Project Office QA program were summarized by Wegner (1989); Williams (1996, 1997); Rattray (2012); Davis and others, (2013); and Rattray (2014). Wegner (1989) also statistically compared analytical results among different laboratories used from 1980 to 1988. Analyses of water-sample pairs were in statistical agreement for more than 95 percent of the samples compared. Some outliers occurred; in cases where replicates were collected, data from the samples with the most reasonable result compared with the long-term trend were used in the trend analyses.

\section{Guidelines for Interpretation of Analytical Results}

Concentrations of radionuclides are reported with an estimated sample standard deviation, $\boldsymbol{s}$, which is obtained by propagating sources of analytical uncertainty in measurements. McCurdy and others (2008) provided details on interpreting radiological data used by the USGS. The guidelines for interpreting analytical results are based on an extension of a method proposed by Currie (1984) and are given in Davis and others (2013). In this report, radionuclide concentrations of less than $3 s$ are considered to be less than the "reporting level." The reporting level should not be confused with the analytical method detection limit, which is based on laboratory procedures.

Concentrations of inorganic and organic constituents are reported with reference to long term method detection levels (LT-MDL), LRL, and interim reporting levels (IRLs), or with reference to minimum reporting levels (MRLs). Childress and others (1999) provided details about the approach used by the USGS regarding detection and reporting levels. The USGS Office of Water Quality Technical Memorandum 2010.07 (U.S. Geological Survey, 2010) outlines changes to data reporting by the NWQL for inorganic and organic constituents. The primary change was that the reporting level for most inorganic constituents was set at the LT-MDL. The method detection limit is the minimum concentration of a substance that can be measured and reported with 99-percent confidence that the concentration is greater than zero. The LRL is the concentration at which the false negative error rate is minimized to be no more than 1 percent of the reported results. The MRL uses a censor-limit based reporting level below which no data are reported and is set at a concentration greater than the detection limit of the analyte. The LRL generally is equal to twice the yearly determined LT-MDL, which is a detection level derived by determining the standard deviation of a minimum of 24 MDL spike-sample measurements over an extended time. These reporting levels may be described as preliminary (IRL) for a developmental method if the levels have been based on a small number of analytical results. 
Table 2. Site information for wells at and near the Idaho National Laboratory, Idaho.

[See figures 2 and $\underline{3}$ for well locations. Local name: Local well identifier used in this study. Site identifier: Unique numerical identifier used to access well data from the U.S. Geological Survey National Water Information System (http://waterdata.usgs.gov/nwis). Pump installation date: Date the first pump was installed in the well. Abbreviations: ft BLS, feet below land surface; NWQL, National Water Quality Laboratory; RESL, Radiological and Environmental Sciences Laboratory; NA, not applicable]

\begin{tabular}{|c|c|c|c|c|c|}
\hline \multicolumn{2}{|c|}{ Sampling sites } & \multirow{2}{*}{$\begin{array}{l}\text { Well depth } \\
\text { (ft BLS) }\end{array}$} & \multicolumn{2}{|c|}{ Period of record } & \multirow{2}{*}{$\begin{array}{c}\text { Pump } \\
\text { installation } \\
\text { date }\end{array}$} \\
\hline Local name & Site identifier & & $\begin{array}{c}\text { NWOL } \\
\text { chemical data }\end{array}$ & $\begin{array}{c}\text { RESL } \\
\text { radiochemical data }\end{array}$ & \\
\hline \multicolumn{6}{|c|}{ Aquifer wells } \\
\hline \multicolumn{6}{|c|}{ Idaho Nuclear Technology and Engineering Center } \\
\hline CPP 1 & 433433112560201 & 586 & $1977-2012$ & $1972-2012$ & $12-07-1950$ \\
\hline CPP 2 & 433432112560801 & 605 & $1981-2012$ & $1972-2012$ & 03-12-1951 \\
\hline RIFLE RANGE & 433243112591101 & 620 & $1988-2012$ & $1988-2012$ & 06-29-1988 \\
\hline USGS 20 & 433253112545901 & 658 & 1968-2012 & 1966-2012 & 09-07-1990 \\
\hline USGS 34 & 433334112565501 & 700 & $1977-2012$ & 1966-2012 & 08-14-1990 \\
\hline USGS 35 & 433339112565801 & 579 & 1977-2012 & $1972-2012$ & 08-09-1990 \\
\hline USGS 36 & 433330112565201 & 567 & $1977-2012$ & 1966-2012 & 08-14-1990 \\
\hline USGS 37 & 433326112564801 & 572 & $1971-2012$ & 1966-2012 & $06-1993^{1}$ \\
\hline USGS 38 & 433322112564301 & 612 & 1977-2012 & 1966-2012 & 09-26-1990 \\
\hline USGS 39 & 433343112570001 & 493 & 1977-2012 & $1972-2012$ & 08-09-1990 \\
\hline USGS 40 & 433411112561101 & 483 & $1977-2010$ & $1972-2010$ & $07-1980^{1}$ \\
\hline USGS 41 & 433409112561301 & 674 & 1977-2012 & $1972-2012$ & 08-15-1990 \\
\hline USGS 42 & 433404112561301 & 678 & 1977-2012 & 1972-2012 & 08-15-1990 \\
\hline USGS 43 & 433415112561501 & 676 & 1977-2012 & $1972-2012$ & $07-1980^{1}$ \\
\hline USGS 44 & 433409112562101 & 650 & 1977-2012 & $1967-2012$ & 07-02-1990 \\
\hline USGS 45 & 433402112561801 & 651 & 1977-2012 & $1972-2012$ & 07-26-1990 \\
\hline USGS 46 & 433407112561501 & 651 & 1977-2012 & $1972-2012$ & 07-26-1990 \\
\hline USGS 47 & 433407112560301 & 652 & $1977-2012$ & $1972-2012$ & $10-1975^{1}$ \\
\hline USGS 48 & 433401112560301 & 750 & $1977-2012$ & $1972-2012$ & 08-08-1990 \\
\hline USGS 51 & 433350112560601 & 647 & 1960-2012 & $1972-2012$ & 06-26-1987 \\
\hline USGS 52 & 433414112554201 & 602 & $1977-2012$ & $1972-2012$ & 06-24-1987 \\
\hline USGS 57 & 433344112562601 & 582 & 1971-2012 & $1972-2012$ & 06-23-1987 \\
\hline USGS 59 & 433354112554701 & 657 & 1977-2012 & 1972-2012 & 06-24-1987 \\
\hline USGS 67 & 433344112554101 & 694 & 1977-2012 & $1972-2012$ & $07-1980^{1}$ \\
\hline USGS 77 & 433315112560301 & 586 & 1968-2012 & 1966-2012 & 07-26-1990 \\
\hline USGS 82 & 433401112551001 & 693 & 1984-2012 & $1972-2012$ & $06-25-1987$ \\
\hline USGS 84 & 433356112574201 & 505 & 1984-2012 & $1972-2012$ & 07-29-1992 \\
\hline USGS 85 & 433246112571201 & 614 & 1968-2012 & 1966-2012 & 08-23-1990 \\
\hline USGS 111 & 433331112560501 & 560 & 1986-2012 & $1985-2012$ & 01-22-1985 \\
\hline USGS 112 & 433314112563001 & 563 & 1986-2012 & $1985-2012$ & 01-26-1985 \\
\hline USGS 113 & 433314112561801 & 564 & 1986-2012 & 1985-2012 & 01-25-1985 \\
\hline USGS 114 & 433318112555001 & 560 & 1986-2012 & 1985-2012 & 01-24-1985 \\
\hline USGS 115 & 433320112554101 & 581 & 1986-2012 & 1985-2012 & 01-23-1985 \\
\hline USGS 116 & 433331112553201 & 572 & 1986-2012 & 1985-2012 & 01-30-1985 \\
\hline USGS 123 & 433352112561401 & 481 & 1991-2012 & 1991-2012 & 04-05-1994 \\
\hline USGS 128 & 433250112565601 & 615 & 2001-2012 & 2001-2012 & 08-19-2002 \\
\hline \multicolumn{6}{|c|}{ Advanced Test Reactor Complex } \\
\hline MTR TEST & 433520112572601 & 588 & 1984-2012 & $1972-2012$ & 01-15-1986 \\
\hline TRA Disposal & 433506112572301 & 1,267 & 1986-2012 & $1985-2012$ & 02-04-1986 \\
\hline USGS 58 & 433500112572502 & 503 & 1977-2012 & $1962-2012$ & 01-16-1986 \\
\hline USGS 65 & 433447112574501 & 498 & 1967-2012 & 1969-2012 & $10-05-1977$ \\
\hline USGS 76 & 433425112573201 & 718 & 1981-2012 & $1972-2012$ & 01-17-1986 \\
\hline USGS 79 & 433505112581901 & 702 & 1984-2012 & $1972-2012$ & 08-23-1990 \\
\hline
\end{tabular}


Table 2. Site information for wells at and near the Idaho National Laboratory, Idaho.-Continued

[See figures 2 and $\underline{3}$ for well locations. Local name: Local well identifier used in this study. Site identifier: Unique numerical identifier used to access well data from the U.S. Geological Survey National Water Information System (http://waterdata.usgs.gov/nwis). Pump installation date: Date the first pump was installed in the well. Abbreviations: $\mathrm{ft} \mathrm{BLS}$, feet below land surface; NWQL, National Water Quality Laboratory; RESL, Radiological and Environmental Sciences Laboratory; NA, not applicable]

\begin{tabular}{|c|c|c|c|c|c|}
\hline \multicolumn{2}{|c|}{ Sampling sites } & \multirow{2}{*}{$\begin{array}{l}\text { Well depth } \\
\text { (ft BLS) }\end{array}$} & \multicolumn{2}{|c|}{ Period of record } & \multirow{2}{*}{$\begin{array}{c}\text { Pump } \\
\text { installation } \\
\text { date }\end{array}$} \\
\hline Local name & Site identifier & & $\begin{array}{c}\text { NWOL } \\
\text { chemical data }\end{array}$ & $\begin{array}{c}\text { RESL } \\
\text { radiochemical data }\end{array}$ & \\
\hline \multicolumn{6}{|c|}{ Aquifer wells-Continued } \\
\hline \multicolumn{6}{|l|}{ Central Facilities Area } \\
\hline CFA 1 & 433204112562001 & 639 & $1970-2012$ & 1966-2012 & $07-1943^{1}$ \\
\hline CFA 2 & 433144112563501 & 681 & $1977-2012$ & 1966-2012 & 01-18-1949 \\
\hline CFA LF 3-9 & 433216112571001 & 500 & $1993-2007$ & $1993-2007$ & $07-1994^{1}$ \\
\hline CFA LF 2-10 & 433216112563301 & 716 & $1993-2012$ & $1993-2012$ & 06-26-1991 \\
\hline USGS 127 & 433058112572201 & 596 & 2000-2012 & 2000-2012 & $09-12-2000$ \\
\hline \multicolumn{6}{|c|}{ Radioactive Waste Management Complex } \\
\hline RWMC M1SA & 432956113030901 & 638 & $1993-2012$ & $1993-2012$ & $08-27-1992$ \\
\hline RWMC M3S & 433008113021801 & 633 & $1993-2012$ & $1993-2012$ & 09-04-1992 \\
\hline RWMC M7S & 433023113014801 & 628 & $1993-2012$ & $1993-2012$ & 09-01-1992 \\
\hline RWMC M11S & 433058113010401 & 624 & $2000-2012$ & $2000-2012$ & $1998^{1}$ \\
\hline RWMC M12S & 433118112593401 & 572 & 2000-2012 & 2000-2012 & $1998^{1}$ \\
\hline RWMC M13S & 433037113002701 & 643 & $2000-2012$ & 2000-2012 & $1998^{1}$ \\
\hline RWMC M14S & 433052113025001 & 635 & 2000-2012 & $2000-2012$ & $1998^{1}$ \\
\hline RWMC Production & 433002113021701 & 685 & $1981-2012$ & 1977-2012 & $11-25-1974$ \\
\hline USGS 87 & 433013113024201 & 673 & 1977-2012 & 1972-2012 & $10-1974^{1}$ \\
\hline USGS 88 & 432940113030201 & 662 & $1981-2011$ & 1972-2011 & $10-1974^{1}$ \\
\hline USGS 89 & 433005113032801 & 637 & $1981-2012$ & 1972-2012 & $07-1975^{1}$ \\
\hline USGS 120 & 432919113031501 & 705 & $1987-2012$ & $1987-2012$ & $11-12-1987$ \\
\hline \multicolumn{6}{|l|}{ South of facilities } \\
\hline USGS 104 & 432856112560801 & 700 & 1984-2012 & $1980-2012$ & $01-27-1986$ \\
\hline USGS 105 & 432703113001801 & 1,290 & $1981-2007$ & 1980-2007 & $11-1983^{1}$ \\
\hline USGS 106 & 432959112593101 & 760 & 1981-2012 & 1980-2012 & 01-13-1981 \\
\hline USGS 108 & 432659112582601 & 1,192 & 1984-2008 & $1980-2008$ & $11-1983^{1}$ \\
\hline USGS 124 & 432307112583101 & 800 & $1994-2012$ & $1994-2012$ & $04-1994^{1}$ \\
\hline \multicolumn{6}{|c|}{ Perched groundwater wells } \\
\hline \multicolumn{6}{|c|}{ Idaho Nuclear Technology and Engineering Center } \\
\hline PW 1 & 433349112560701 & 117 & 1989-2002 & 1987-2002 & NA \\
\hline PW 2 & 433344112555601 & 131 & 1989-2002 & $1987-2002$ & NA \\
\hline PW 3 & 433351112555701 & 123 & 1989-2002 & 1987-2002 & NA \\
\hline PW 4 & 433348112554901 & 150 & 1989-2007 & 1987-2006 & 06-15-1992 \\
\hline PW 5 & 433348112555701 & 129 & 1989-2002 & $1987-2002$ & 09-28-1993 \\
\hline PW 6 & 433353112562201 & 125 & 1989-2000 & $1987-2000$ & NA \\
\hline USGS 50 & 433419112560201 & 405 & $1977-2008$ & $1967-2008$ & $12-1994^{1}$ \\
\hline \multicolumn{6}{|c|}{ Advanced Test Reactor Complex } \\
\hline CWP 1 & 433459112572601 & 58 & 1989-2012 & 1982-2012 & NA \\
\hline CWP 2 & 433458112572401 & 50 & 1989-2001 & 1983-2001 & NA \\
\hline CWP 3 & 433455112572501 & 55 & 1989-2012 & 1982-2012 & NA \\
\hline CWP 4 & 433454112572601 & 61 & 1989-2010 & $1982-2010$ & NA \\
\hline CWP 5 & 433455112572901 & 52 & 1989-2001 & $1982-2001$ & NA \\
\hline CWP 8 & 433500112573001 & 64 & 1989-2012 & 1982-2012 & NA \\
\hline PW 7 & 433446112574602 & 237 & 1987-1994 & NA & NA \\
\hline PW 8 & 433456112572001 & 166 & 1989-2012 & 1987-2012 & 06-15-1992 \\
\hline PW 9 & 433500112575401 & 200 & $1987-2012$ & 1987-2012 & 06-15-1992 \\
\hline
\end{tabular}


Table 2. Site information for wells at and near the Idaho National Laboratory, Idaho._-Continued

[See figures 2 and $\underline{3}$ for well locations. Local name: Local well identifier used in this study. Site identifier: Unique numerical identifier used to access well data from the U.S. Geological Survey National Water Information System (http://waterdata.usgs.gov/nwis). Pump installation date: Date the first pump was installed in the well. Abbreviations: ft BLS, feet below land surface; NWQL, National Water Quality Laboratory; RESL, Radiological and Environmental Sciences Laboratory; NA, not applicable]

\begin{tabular}{|c|c|c|c|c|c|}
\hline \multicolumn{2}{|c|}{ Sampling sites } & \multirow{2}{*}{$\begin{array}{l}\text { Well depth } \\
\text { (ft BLS) }\end{array}$} & \multicolumn{2}{|c|}{ Period of record } & \multirow{2}{*}{$\begin{array}{c}\text { Pump } \\
\text { installation } \\
\text { date }\end{array}$} \\
\hline Local name & Site identifier & & $\begin{array}{c}\text { NWOL } \\
\text { chemical data }\end{array}$ & $\begin{array}{l}\text { RESL } \\
\text { radiochemical data }\end{array}$ & \\
\hline \multicolumn{6}{|c|}{ Perched groundwater wells-Continued } \\
\hline \multicolumn{6}{|c|}{ Advanced Test Reactor Complex-Continued } \\
\hline TRA A13 & 433502112572802 & 59 & 1989-2001 & 1972-2001 & NA \\
\hline TRA A77 & 433507112573801 & 34 & 1989-1997 & $1972-1997$ & NA \\
\hline USGS 53 & 433503112573401 & 71 & 1981-2012 & 1968-2012 & 08-08-1990 \\
\hline USGS 54 & 433503112572801 & 82 & $1981-2012$ & $1962-2012$ & $10-12-1993$ \\
\hline USGS 55 & 433508112573001 & 81 & 1981-2012 & 1962-2012 & 09-23-1993 \\
\hline USGS 56 & 433509112573501 & 80 & 1981-2012 & 1962-2012 & 09-28-1993 \\
\hline USGS 60 & 433456112571901 & 117 & 1984-2011 & 1966-2011 & 06-15-1992 \\
\hline USGS 61 & 433453112571601 & 123 & $1986-2012$ & 1966-2012 & 06-16-1992 \\
\hline USGS 62 & 433446112570701 & 165 & 1984-2012 & 1962-2012 & 06-17-1992 \\
\hline USGS 63 & 433455112574001 & 97 & 1986-2012 & 1962-2012 & 06-16-1992 \\
\hline USGS 66 & 433436112564801 & 475 & 1989-2012 & 1966-2012 & NA \\
\hline USGS 68 & 433516112573901 & 128 & $1962-2012$ & 1972-2012 & 06-16-1992 \\
\hline USGS 69 & 433450112573001 & 115 & 1986-2012 & 1967-2012 & 06-16-1992 \\
\hline USGS 70 & 433504112571001 & 100 & 1981-2012 & 1962-2012 & 06-17-1992 \\
\hline USGS 71 & 433439112571501 & 171 & 1987-2012 & 1962-2012 & 06-17-1992 \\
\hline USGS 72 & 433519112574601 & 200 & 1989-2012 & 1974-2012 & 09-23-1993 \\
\hline USGS 73 & 433502112575401 & 127 & 1986-2012 & 1962-2012 & $2003^{1}$ \\
\hline USGS 78 & 433413112573501 & 204 & 1986-2012 & 1972-2012 & NA \\
\hline \multicolumn{6}{|c|}{ Radioactive Waste Management Complex } \\
\hline USGS 92 & 433000113025301 & 214 & $1972-2012$ & 1972-2012 & NA \\
\hline
\end{tabular}

${ }^{1}$ Estimated date based on month or year of initial installation.

These levels also may vary from sample to sample for the same constituent and the same method, if matrix effects or other factors arise that interfere with the analysis.

Concentrations measured between the LT-MDL and the LRL may be described as estimated values and are considered "qualitatively detected analytes" (Childress and others, 1999, p. 7). For most of the constituents in this report, concentrations generally are greater than the LT-MDLs, LRLs, or MRLs; however, some concentrations are reported as less than the LT-MDL or LRL and some concentrations are estimated.

\section{Statistical Data Analysis Methods}

Water-quality data collected for the monitoring program were analyzed using the summary statistics of mean, median, minimum, maximum, and standard deviation. The data were processed using custom computer scripts developed in the $\mathrm{R}$ programming language ( $\mathrm{R}$ Development Core Team, 2014). All R functions written for this report are stored in an R-package called "Trends" (Fisher and Davis, 2014); function documentation and processing instructions for this package are given in appendix A. R-package installation instructions are located at https://github.com/jisher-usgs/Trends/blob/master/ README.md.

In addition to the base packages included with $\mathrm{R}$, Trends depends on the "Survival" package (Therneau and Grambsch, 2000; Therneau, 2014), a contributed package available on the Comprehensive R Archive Network. The Trends package identifies statistical trends in water-quality data for multiple constituents and sample sites using a parametric survival regression model for left-censored data (values reported as less than a LRL), interval-censored data (data with an associated uncertainty), and uncensored data. This package also calculates summary statistics for multiple constituents and automates plotting of data and regression lines. A measured value is converted to censored data under the following conditions: (1) the measured value is less than the reporting level and is represented as left-censored data; or (2) there is a standard deviation and detection limit associated with the measured value; therefore, it is represented as interval-censored data. The upper and lower bounds of interval-censored data are calculated by adding and subtracting 
three standard deviations to or from the measured value, respectively. Note that interval-censored data with a lower or upper bound less than the detection level is represented as left-censored data. For left-censored data, the upper bound is set to the detection level when its magnitude is less than the detection level. For datasets with estimated (E) concentrations, the E-value was treated the same as a concentration for an uncensored value.

Data were analyzed using the "RunAnalysis" function in the Trends package (appendix A), which uses the "survreg" function provided in the survival package. The survreg function uses methods to manage statistics for left-censored, interval-censored, and uncensored environmental data. The survreg function was used to fit a parametric survival regression model to the censored and uncensored data. The specific class of survival model is known as the accelerated failure time (AFT) model. A maximum-likelihood estimation (MLE) method is used to estimate parameters in the AFT model. The MLE is solved by maximizing the log-likelihood using the Newton-Raphson method, an iterative root-finding algorithm. The likelihood function is dependent on the distribution of the measured data. Data were assumed to follow a log-normal distribution because most of the variables have values spanning two or more orders of magnitude. If all observations are uncensored, the survival regression becomes identical to ordinary least squares regression. Summary statistics were not calculated for constituents when all concentrations were less than the reporting level.

The null hypothesis of the trend test was that the slope (the coefficient relating time and concentration) was zero; the alternate hypothesis was that the slope was not zero. A significance level of 0.05 was selected to determine if the slope was statistically significant. A two-sided $p$-value that was less than or equal to 0.05 indicated that there was a statistically significant slope, and the null hypothesis was rejected. The $p$-value is the linear trend over time for each dataset run. The sign of the slope indicated if there was an increasing or decreasing trend. If $p$-values were greater than 0.05 , the slope was not statistically significant, and the null hypothesis was accepted. In some cases, the regression model could not determine if a trend was present because the AFT model failed to reach convergence after 100 iterations; no trend was assumed present when this occurred.

For selected datasets, water level, seasonal variability in sampling, and water level and seasonal variability were used as explanatory variables in the survival regression model. Results for $p$-values for comparison are given in table 3 , and the description of the analyses is given in the Trends package in appendix A.

Table 3. Comparison of trend analyses for selected wells using additional explanatory variables, included as covariates to the trend model, Idaho National Laboratory, Idaho.

[See figures 2 and $\underline{3}$ for well locations. Local name: Local well identifier used in this study. Trend: +, increasing; - , decreasing. $p$ value is for linear trend over time. Reg: $p$ values for temporal trend analyses done for this study. WL: $p$ values for trend with residual water level as an additional explanatory variable. Seasonal: $p$ values for trends with seasonality as an additional explanatory variable. WL and seasonal: $p$ values for trend with both residual water levels and seasonality as additional explanatory variables]

\begin{tabular}{|c|c|c|c|c|c|c|c|c|}
\hline $\begin{array}{l}\text { Local } \\
\text { name }\end{array}$ & Reg & Trend & WL & Trend & Seasonal & Trend & $\begin{array}{l}\text { WL and } \\
\text { seasonal }\end{array}$ & Trend \\
\hline \multicolumn{9}{|c|}{ Chloride } \\
\hline USGS 35 & 0.000 & - & 0.000 & - & 0.000 & - & 0.000 & - \\
\hline USGS 39 & 0.128 & none & 0.481 & none & 0.076 & none & 0.674 & none \\
\hline USGS 114 & 0.000 & + & 0.000 & + & 0.000 & + & 0.000 & + \\
\hline USGS 87 & 0.000 & + & 0.000 & + & 0.000 & + & 0.000 & + \\
\hline PW 8 & 0.089 & none & 0.124 & none & 0.051 & none & 0.061 & none \\
\hline \multicolumn{9}{|c|}{ Sulfate } \\
\hline USGS 35 & 0.000 & + & 0.019 & + & 0.000 & + & 0.019 & + \\
\hline USGS 39 & 0.000 & + & 0.049 & + & 0.000 & + & 0.085 & none \\
\hline USGS 114 & 0.177 & none & 0.180 & none & 0.244 & none & 0.262 & none \\
\hline USGS 87 & 0.546 & none & 0.368 & none & 0.684 & none & 0.616 & none \\
\hline PW 8 & 0.049 & - & 0.009 & - & 0.003 & - & 0.001 & - \\
\hline \multicolumn{9}{|c|}{ Sodium } \\
\hline USGS 35 & 0.002 & - & 0.000 & - & 0.014 & - & 0.004 & - \\
\hline USGS 39 & 0.026 & + & 0.030 & + & 0.033 & + & 0.070 & none \\
\hline USGS 114 & 0.173 & none & 0.162 & none & 0.190 & none & 0.194 & none \\
\hline USGS 87 & 0.000 & + & 0.000 & + & 0.000 & + & 0.000 & + \\
\hline PW 8 & 0.420 & none & 0.619 & none & 0.461 & none & 0.696 & none \\
\hline
\end{tabular}




\section{Water-Quality Characteristics and Trends}

Concentrations of constituents reported during this study represent water samples collected at different time intervals, starting in 1981 when known detection levels were used for radiochemical analyses, and continuing through 2012. Data used for selected plots of trend analyses (appendixes B-E) included all data identified as being reported by the NWQL or RESL that was in the NWIS database as of December 2013, except for some data that were identified as coming from special INL studies or data collected from different depths in the aquifer using a thief sampler. Wells were completed at various depths in the aquifer and with different well completions (for example, single and multiple screened intervals and open boreholes). Data included in NWIS but analyzed by different or unknown laboratories were not used. Data analyzed by the NWQL are routinely uploaded to the NWIS database; however, data from RESL were manually entered from paper copies until 2009. Trends were initially analyzed for entire datasets, but analyses of some wells seemed to indicate that pump installation created a change in the concentrations of some constituents (Bartholomay and others, 2012). Therefore, trends were determined for the period of record from some time after a pump was installed and all samples were analyzed by the NWQL (for nonradiochemical data). Some well pumps were installed for the entire period of record, but trends were analyzed only for data collected from between 1987 and 1989 (depending on the constituents) to 2012 for those wells because some of the earlier data appeared suspect or samples were analyzed by different laboratories with undocumented methods. Between 1987 and 1989, the USGS INL Project Office began using the NWQL for all organic and inorganic chemical analyses, and an established quality-assurance program was used to test sample variability and reproducibility. Trends for tritium and strontium-90 concentration data were analyzed for samples collected from 1981 to 2012 because samples collected prior to 1981 had unknown detection levels. The trends described in this report were based on statistical methods previously described in the statistical methods section of this report. For some datasets, the slope of the line or the visual appearance of the graphed data based on scale make it appear like there is a trend, when statistically, there is no trend.

Physical properties of water measured during sampling events included specific conductance, water temperature, and $\mathrm{pH}$. Samples collected from wells included in this study were analyzed for some combination of the radiochemical and chemical constituents tritium, strontium-90, cesium-137, plutonium-238, plutonium-239, -240 (undivided), americium-241, gross alpha- and beta-particle radioactivity, sodium, chloride, fluoride, sulfate, nitrate (as N), orthophosphate (as P), chromium and other trace elements, TOC, and VOCs. Other constituents have been sampled at some of the wells, but data were not used because concentrations were either less than the reporting levels (in the case of some VOCs) or because data were insufficient to determine a statistically significant trend.

\section{pH, Specific Conductance, and Temperature}

Field measurements of $\mathrm{pH}$, specific conductance, and water temperature were made in all 64 aquifer wells and 35 perched groundwater wells used for this study (igss. $2, \underline{3}$, and 4). Summary statistics for the field measurements for 1989-2012 are given in table 4 (at back of report). Analyses for $\mathrm{pH}$, specific conductance, and water temperature for the datasets are shown in appendix B.

Analyses of trends for $\mathrm{pH}$ indicate that many sites have statistically significant decreasing trends (table 4, appendix B). Of the 64 aquifer wells measured for $\mathrm{pH}, 43$ of the wells showed a decreasing trend, 1 well showed an increasing trend, and 20 wells showed no trend. Of the 35 perched groundwater wells measured, 12 showed a decreasing $\mathrm{pH}$ trend, 3 showed an increasing trend, and 20 had no trend.

The $\mathrm{pH}$ is an indicator of hydrogen ion activity and is collected to understand the acid-base properties of water. Factors that may affect the precision of $\mathrm{pH}$ readings include careful attention to the electrode maintenance, buffer solutions, temperature corrections, instrument electronics, use of different meter brands, and collection methods. Because of variability in each of these factors throughout the history of sample collection, it is difficult to determine specifically whether the noted trends in $\mathrm{pH}$ are actually attributable to changing aquifer conditions or other factors.

Specific conductance is a measure of the electrical conductivity of water and is proportional to the quantities of dissolved chemical constituents in the water so trends in this measurement should be similar to the trends for chloride, sodium, and sulfate concentrations.

Trend analyses of specific conductance from 1989 to 2012 are shown in appendix B. The aerial distribution of trends in specific conductance for aquifer and perched groundwater wells sampled from 1989 to 2012 are shown in figures 5, $\underline{6}$, and 7 . For the 64 aquifer wells (figs. 5 and $\underline{6}$, table 4) that were measured for specific conductance, 34 had a decreasing trend, 14 had an increasing trend, and 16 had no trend. Most of the wells that showed decreasing or no trend are near the INTEC. The decreasing trends may be a response to decreased wastewater disposal since 1989 or discontinued use of the percolation ponds south of the INTEC in 2002. Most aquifer wells that showed an increasing trend are south and southeast of the INTEC, or north of the RWMC. Increasing trends for these wells may be the result of longer groundwater travel times required for the wastewater plume to reach these wells. 


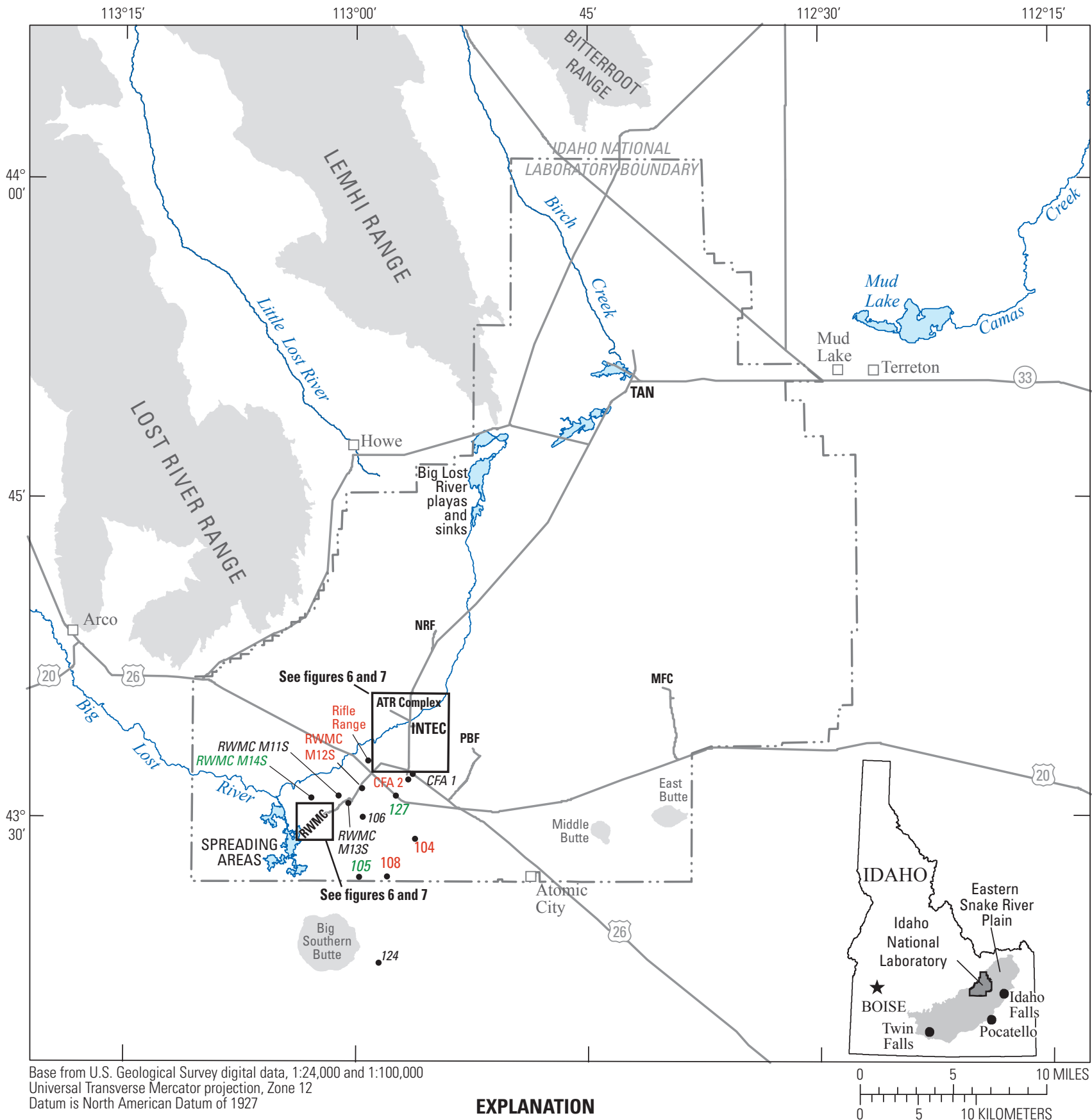

\section{.. B B Boundary of Idaho National Laboratory}

Selected facilities at the Idaho National Laboratory

ATR Complex-Advanced Test Reactor Complex-formerly known as Reactor Technology Complex (RTC) and Test Reactor Area (TRA)

INTEC-Idaho Nuclear Technology and Engineering Center

MFC-Materials and Fuels Complex

NRF-Naval Reactors Facility

PBF-Power Burst Facility

RWMC-Radioactive Waste Management Complex

TAN-Test Area North
Well in the U.S. Geological Survey aquifer identifier

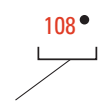

Local well identifier-Number indicates only USGS well; other names are local well names. See table 2 for more information

Color of identifier is indicator of specific conductance measurement trend; red color indicates increasing trend; green indicates decreasing trend; and black indicates no trend

Figure 5. Areal distribution of specific conductance trends in water from selected aquifer wells at and near the Idaho National Laboratory, Idaho. 


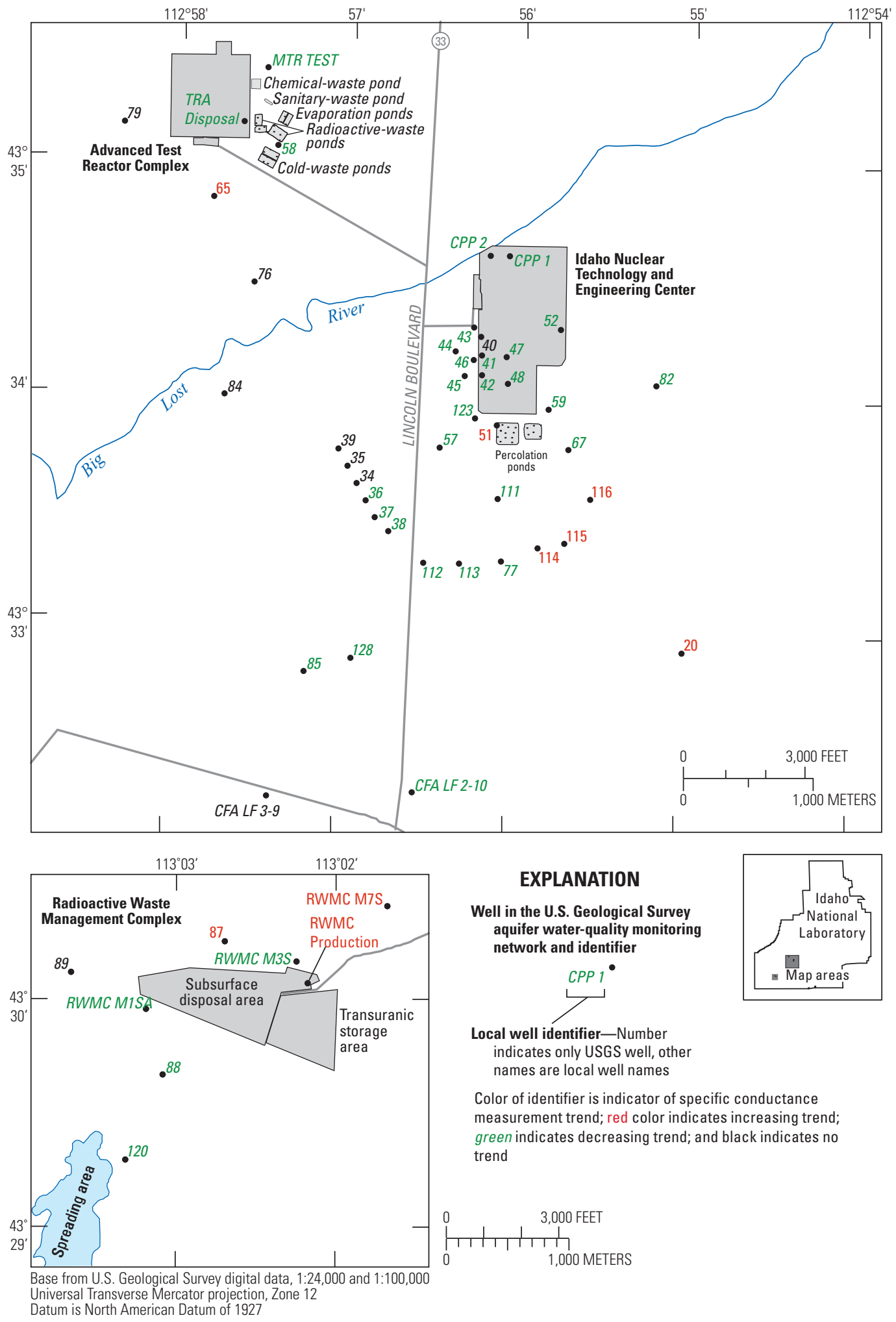

Figure 6. Areal distribution of specific conductance trends in water from selected aquifer wells at the Advanced Test Reactor Complex, Idaho Nuclear Technology and Engineering Center, and the Radioactive Waste Management Complex, Idaho National Laboratory, Idaho. 


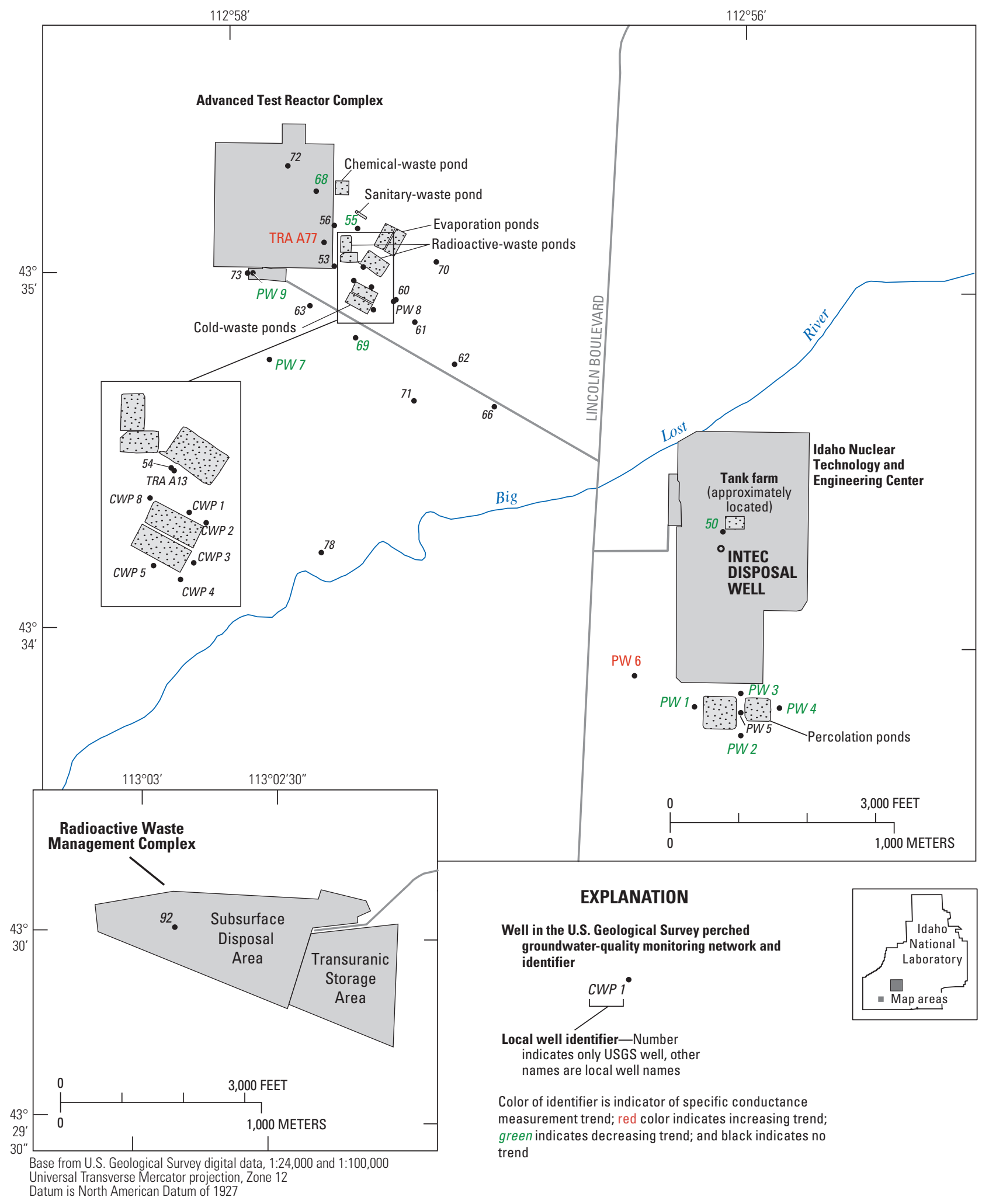

Figure 7. Areal distribution of specific conductance trends in water from selected perched groundwater wells at the Advanced Test Reactor Complex, Idaho Nuclear Technology and Engineering Center, and the Radioactive Waste Management Complex, the Idaho National Laboratory, Idaho. 
Most trends of specific conductance in perched groundwater wells near the INTEC and the ATR Complex were either decreasing or showed no trend (fig. 7, table 4). Only one well at each facility (TRA A77 at the ATR Complex, and PW 6 at the INTEC) had an increasing trend. At the INTEC, the decreasing trend could be attributed to decreased wastewater disposal or discontinued use of the percolation ponds. At the ATR complex, the decrease could be due to closure of the chemical-waste pond (fig. 7) in 1999.

For the 64 aquifer wells measured for statistically significant trends in water temperature, 32 showed a decreasing trend, 3 showed an increasing trend, and 29 showed no trend (figs. 8 and 9). Most wells around INTEC showed a decreasing trend, the cause of which is not certain, although changes could be related to the method of measurement and not to actual changes in the temperature of the aquifer for some of the wells. For example, temperature measurements made prior to 2003 were measured using a sample cup with a mercury thermometer, whereas recently, temperature was measured using a flow-through chamber with a digital thermometer. Of the 35 perched groundwater wells measured for temperature, 13 had a decreasing trend, 5 showed an increasing trend, and 17 showed no trend. All the perched groundwater wells that showed an increasing or decreasing trend were near the ATR Complex (fig. 10), but no pattern of trend is evident for a specific location.

\section{Tritium}

Tritium is a radioactive isotope of hydrogen that is formed in nature by interactions of cosmic rays with gases in the upper atmosphere (Orr and others, 1991). Tritium also is produced in thermonuclear detonations, and it has been discharged in wastewater at several facilities at the INL from the early 1950s to the present. Tritium has a half-life of 12.3 years (Walker and others, 1989, p. 20). Samples were routinely collected and analyzed for tritium from 63 aquifer wells and 33 perched groundwater wells.

Of the 63 aquifer wells that were analyzed for tritium trends, 45 showed decreasing trends, 1 showed an increasing trend, and 17 showed no trends (figs. 11 and 12) (table 5, at back of report). Of the 33 perched groundwater wells that were analyzed for trends, 22 showed a decreasing trend, and 11 showed no trend (fig. 13). The decreasing trends can be attributed to decreased disposal at facilities, and to the radioactive decay of tritium. A lack of trend is evident around the RWMC area (fig. 12). This may be an indication that leakage from buried waste is still contributing tritium to groundwater in this area and maintaining the concentration at a higher level than would be expected from radioactive decay. Some wells in RWMC area show no trend because concentrations in those wells always have been less than the reporting level.

\section{Strontium-90}

Strontium-90 is a fission product of nuclear weapons tests that is present in wastewater discharged at several facilities at the INL (Davis, 2010). Strontium-90 has a half-life of 29.1 years (Walker and others, 1989, p. 29). Water samples have been routinely collected and analyzed for strontium- 90 from 52 aquifer wells and 32 perched groundwater wells.

Of the 52 aquifer wells analyzed for trends, 20 showed a decreasing strontium-90 trend and 32 showed no trend (figs. 14 and 15, table 5). Of the 32 perched groundwater wells that were analyzed for trends, 11 showed a decreasing trend, 2 showed an increasing trend, and 19 showed no trend (fig. 16, table 5). The decreasing trends are generally attributed to lack of recent disposal and to radioactive decay. Wells with no trend generally had concentrations less than the reporting level (tables 5 and $\underline{6}$, at back of report). The two perched groundwater wells that showed an increasing trend (TRA A77 and USGS 55) are near the radioactive-waste infiltration ponds at the ATR complex (fig. 16), and could be influenced by strontium- 90 that was discharged to those ponds before they were replaced by lined evaporation ponds in 1993. The strontium-90 concentrations detected in these two perched groundwater wells also could be attributed to exchange reactions whereby strontium- 90 sorbed to sediment is remobilized into solution in the unsaturated zone beneath the radioactive-waste infiltration ponds.

\section{Cesium-137}

The radionuclide cesium- 137 is a product of nuclear weapons tests and is present in wastewater discharged at several facilities at the INL. Cesium-137 has a half-life of 30.17 years (Walker and others, 1989). The number of samples collected and the number of samples with concentrations greater than the reporting level are shown in table 6. Because concentrations for most samples were less than the reporting level (table 6), no trend analyses were done.

\section{Plutonium}

In 1974, the USGS began monitoring for plutonium-238 and plutonium-239, -240 (undivided) in water from selected wells near TAN, INTEC, and RWMC, because of waste disposal practices. The half-lives of plutonium-238, plutonium-239, and plutonium-240 are 87.7, 24,100, and 6,560 years, respectively (Walker and others, 1989, p. 46). The number of samples collected and the number of samples with concentrations greater than the reporting level are shown in table 6. Because plutonium-238 and plutonium-239, -240 (undivided) concentrations were less than the reporting levels for most samples, no trend analyses were done. 


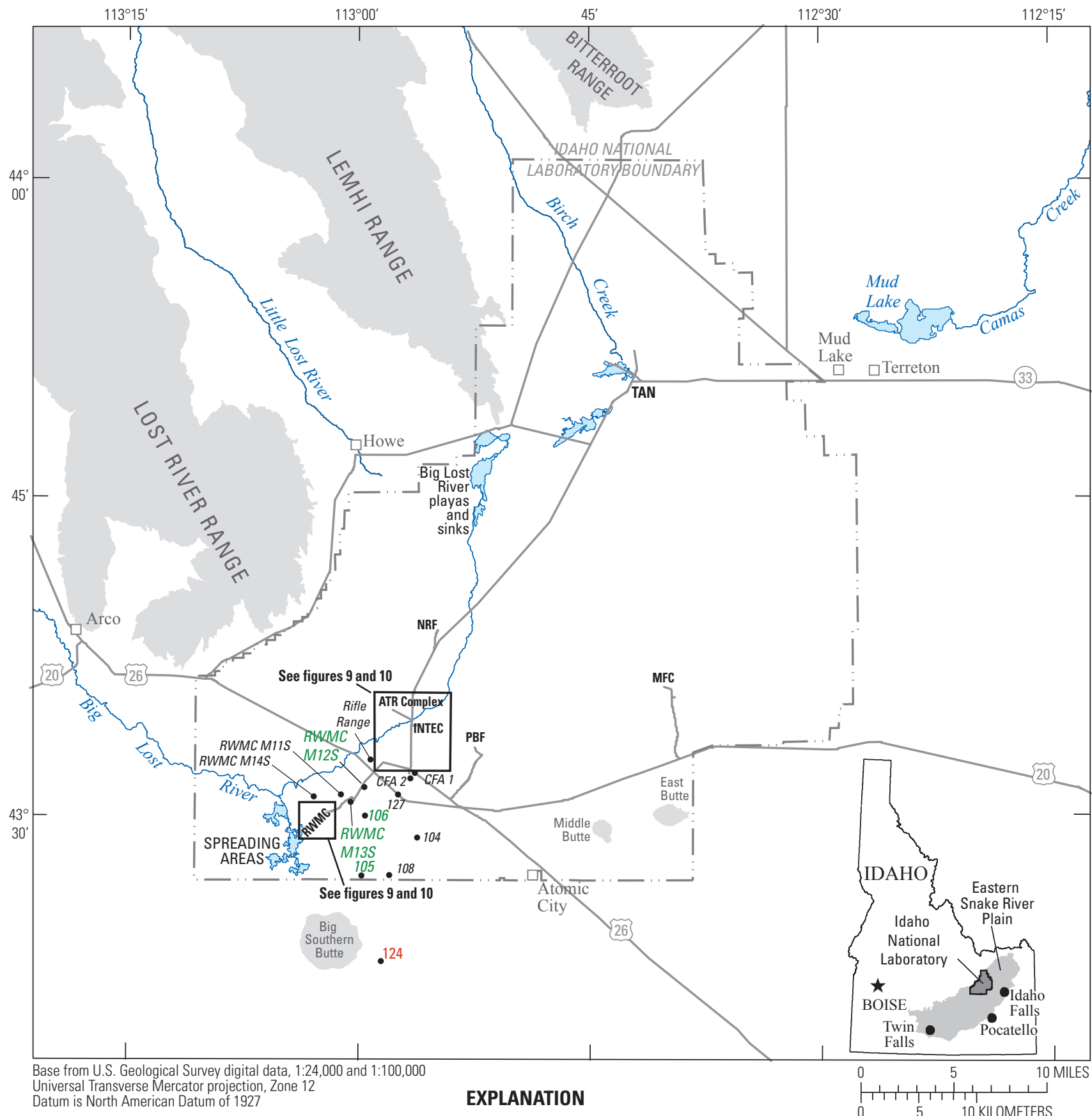

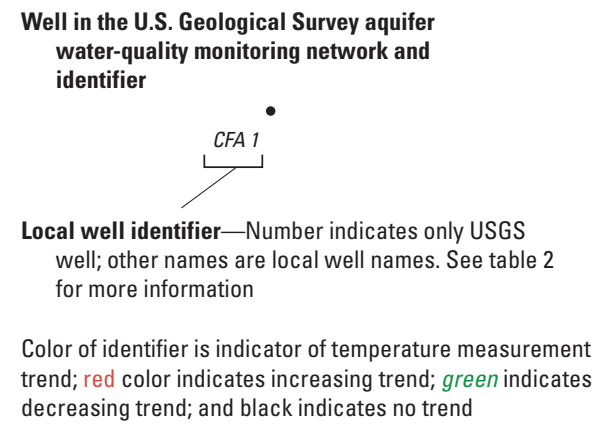

Well in the U.S. Geological Survey aquife water-quality monitoring network and identifier

CFA-Central Facilities Area

INTEC_Idaho Nuclear Technology and Engineering Cente

MFC-Materials and Fuels Complex

NRF-Naval Reactors Facility

PBF-Power Burst Facility

RWMC-Radioactive Waste Management Complex

TAN-Test Area North decreasing trend; and black indicates no trend

Figure 8. Areal distribution of temperature trends in water from selected aquifer wells at and near the Idaho National Laboratory, Idaho. 


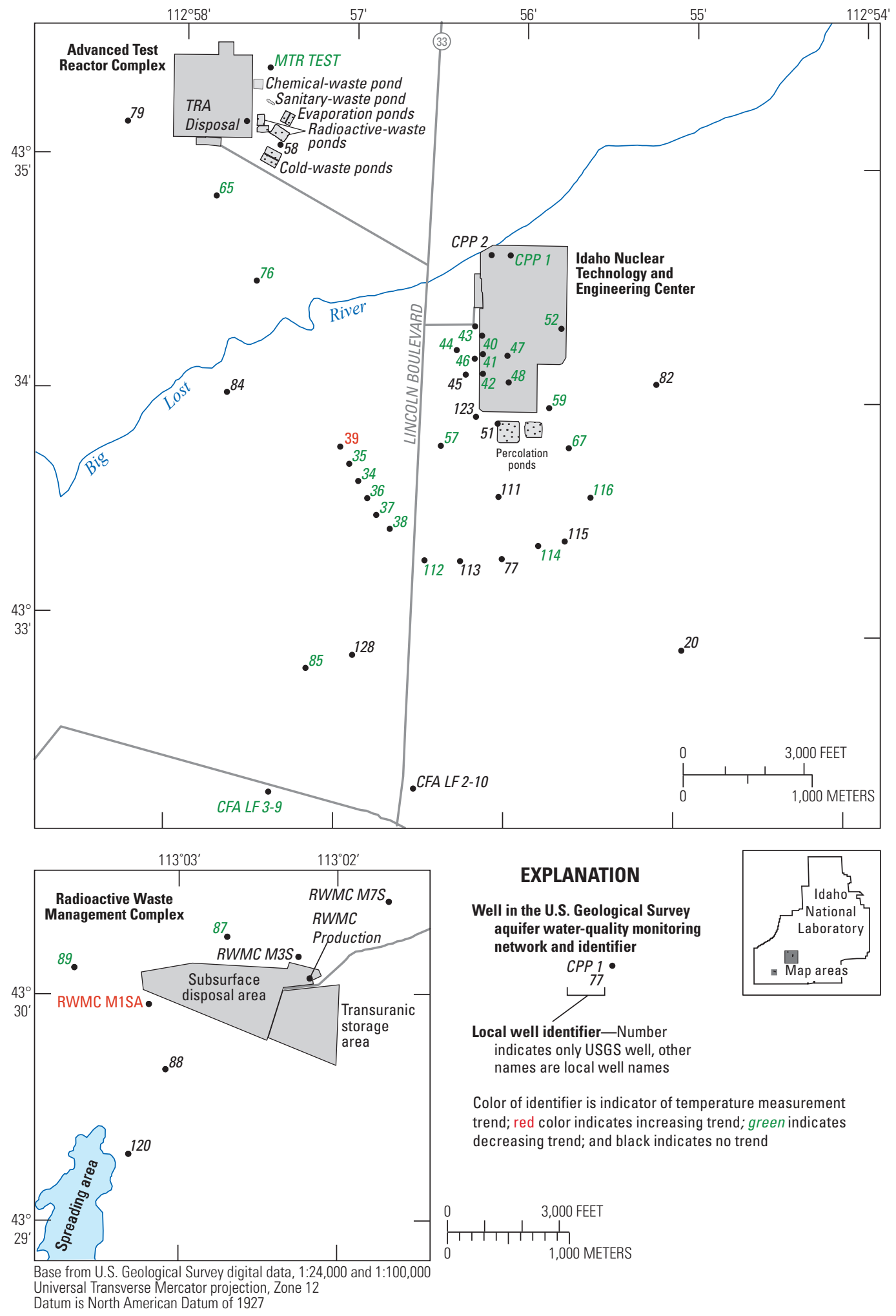

Figure 9. Areal distribution of temperature trends in water from selected aquifer wells at the Advanced Test Reactor Complex, Idaho Nuclear Technology and Engineering Center, and the Radioactive Waste Management Complex, Idaho National Laboratory, Idaho. 


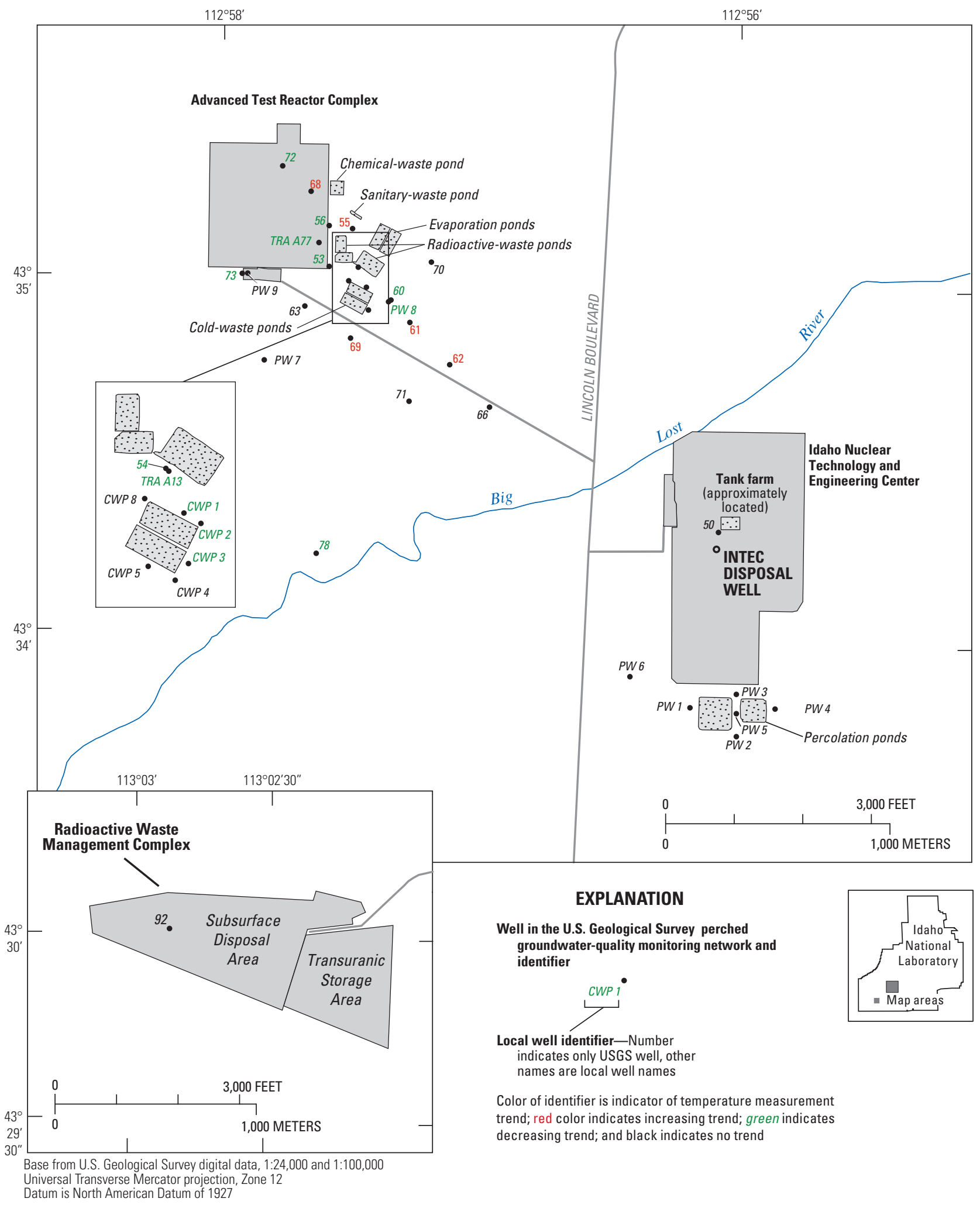

Figure 10. Areal distribution of temperature trends in water from selected perched groundwater wells at the Advanced Test Reactor Complex, Idaho Nuclear Technology and Engineering Center, and the Radioactive Waste Management Complex, Idaho National Laboratory, Idaho. 


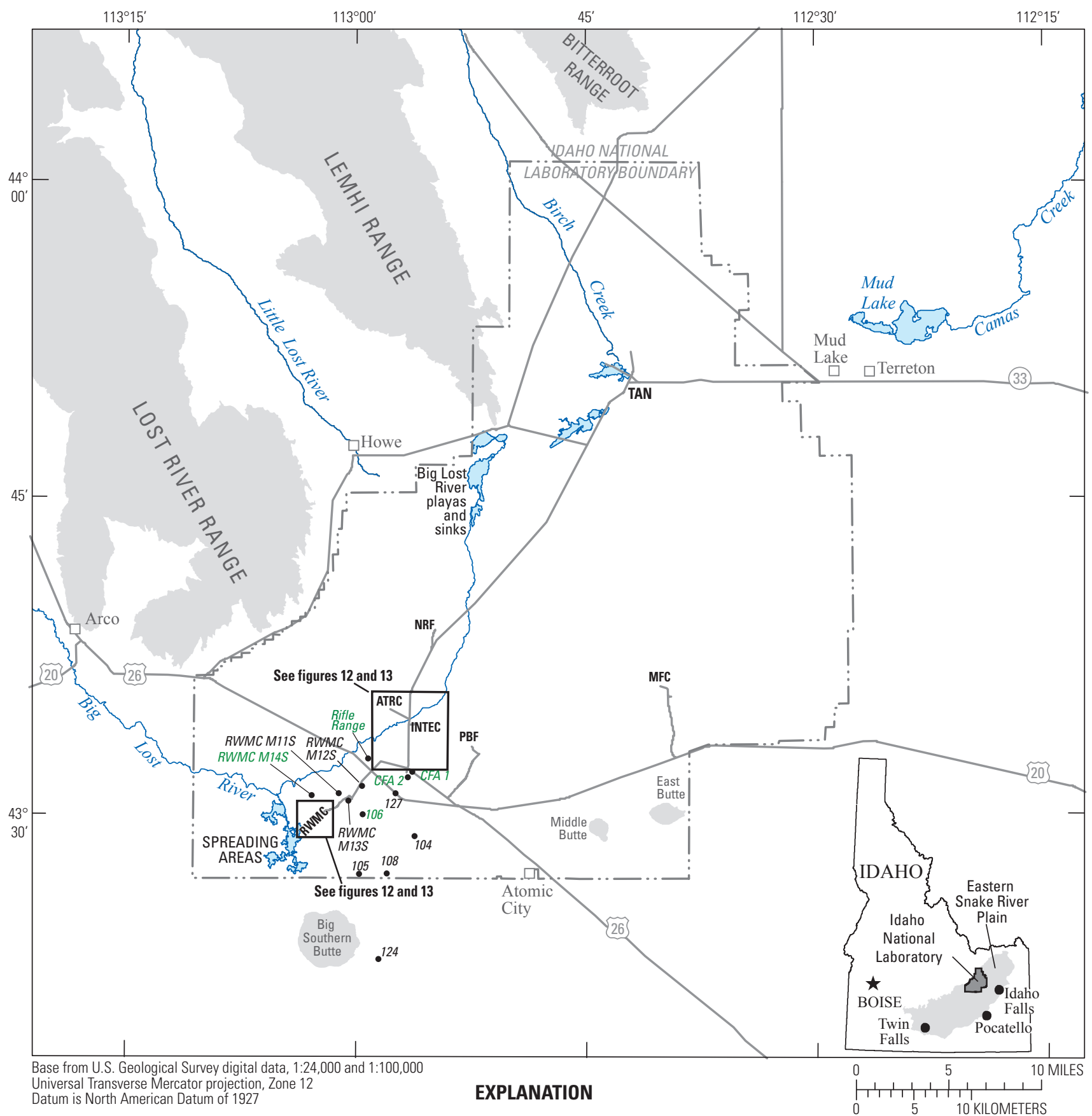

\section{.._- Boundary of Idaho National Laboratory}

Selected facilities at the Idaho National Laboratory

ATR Complex-Advanced Test Reactor Complex-formerly known as

Reactor Technology Complex (RTC) and Test Reactor Area (TRA)

CFA—Central Facilities Area

INTEC-Idaho Nuclear Technology and Engineering Center

MFC—Materials and Fuels Complex

NRF-Naval Reactors Facility

PBF-Power Burst Facility

RWMC-Radioactive Waste Management Complex

Well in the U.S. Geological Survey aquifer water-quality monitoring network and identifier

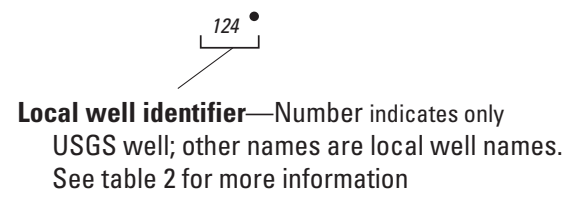

See table 2 for more information

Color of identifier is indicator of tritium trend; green indicates decreasing trend; black indicates no trend.

TAN-Test Area North

Figure 11. Areal distribution of tritium trends in water from selected aquifer wells at and near the Idaho National Laboratory, Idaho. 


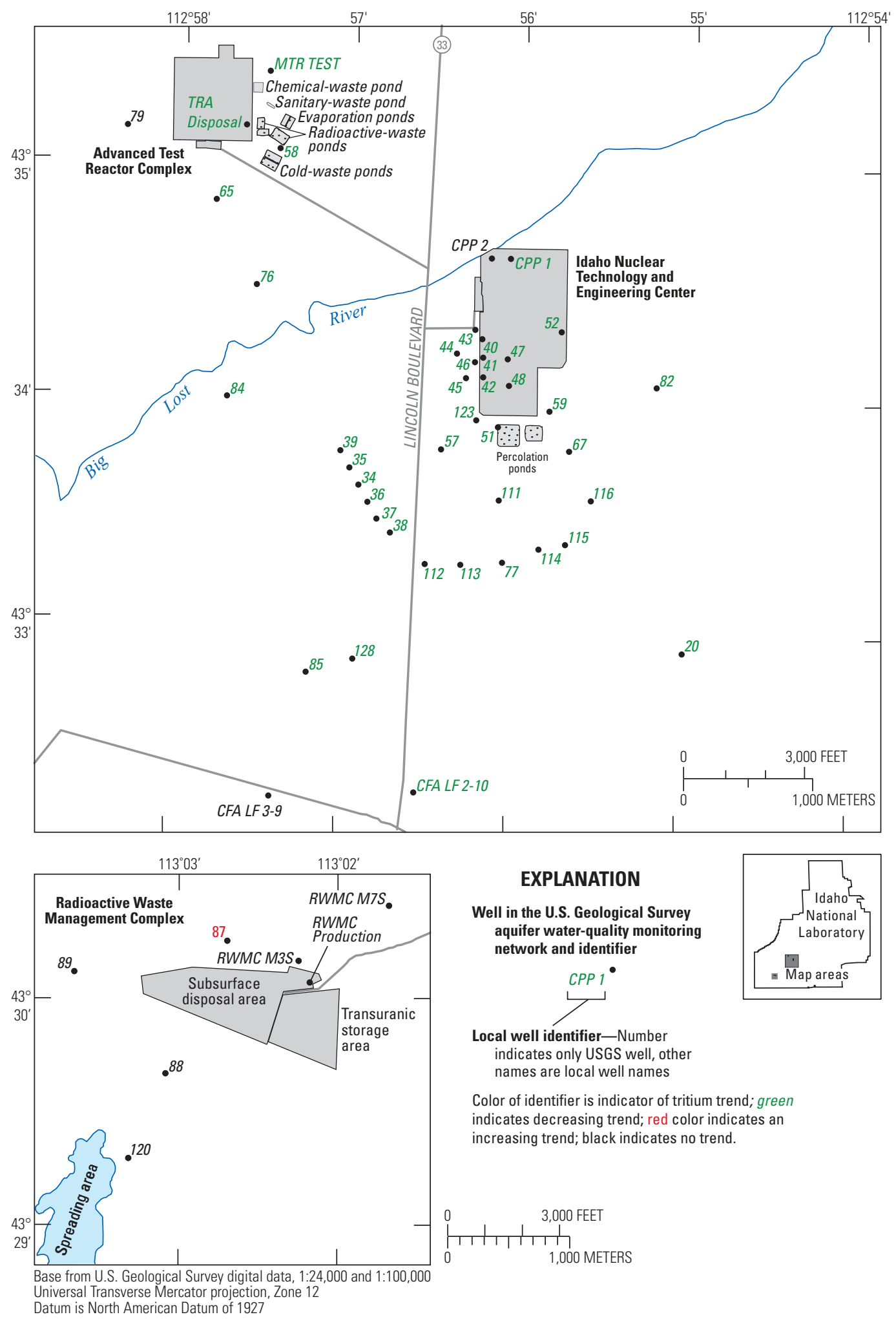

Figure 12. Areal distribution of tritium trends in water from selected aquifer wells at the Advanced Test Reactor Complex, Idaho Nuclear Technology and Engineering Center, and the Radioactive Waste Management Complex, Idaho National Laboratory, Idaho. 


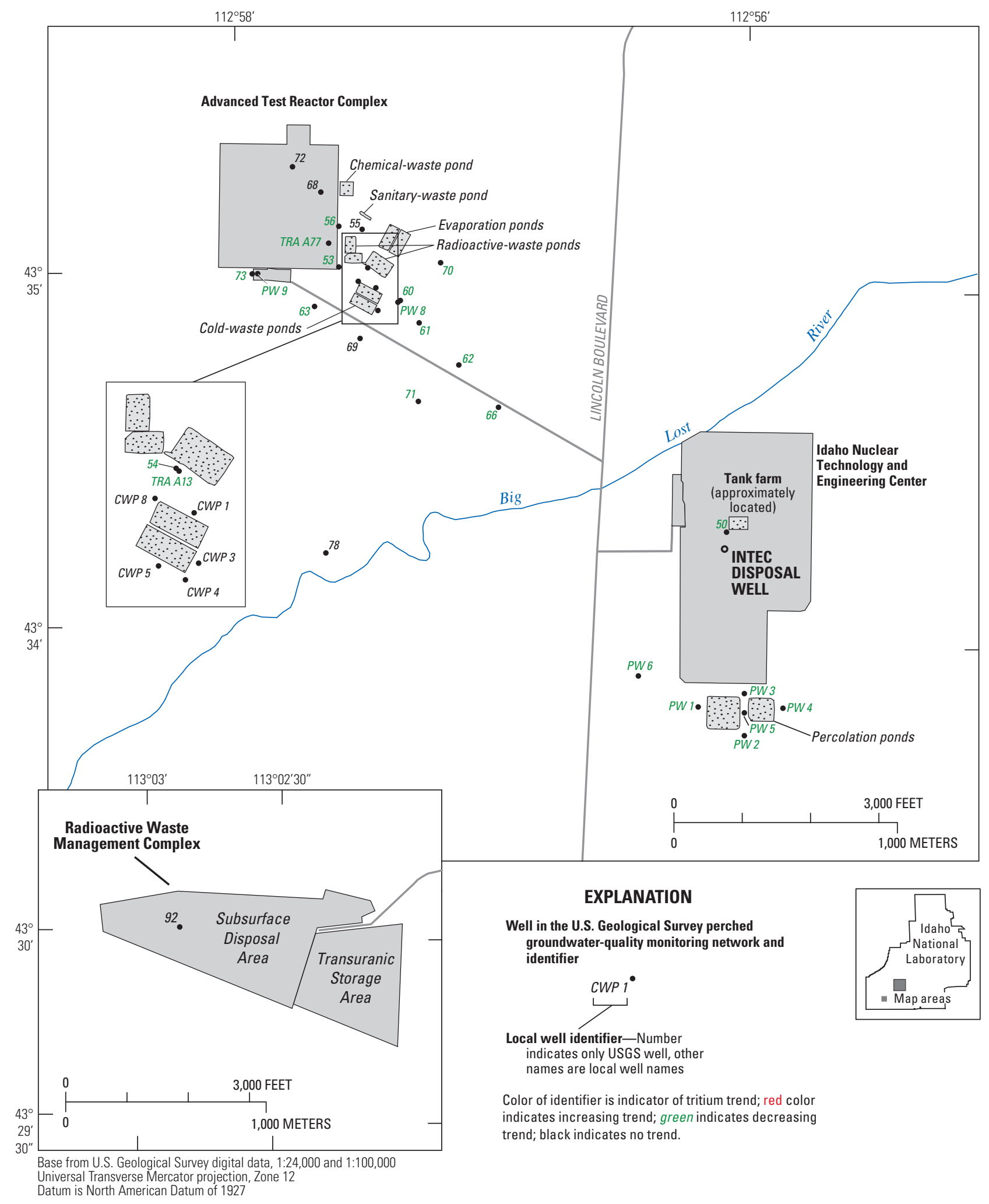

Figure 13. Areal distribution of tritium trends in water from selected perched groundwater wells at the Advanced Test Reactor Complex, Idaho Nuclear Technology and Engineering Center, and the Radioactive Waste Management Complex, Idaho National Laboratory, Idaho. 


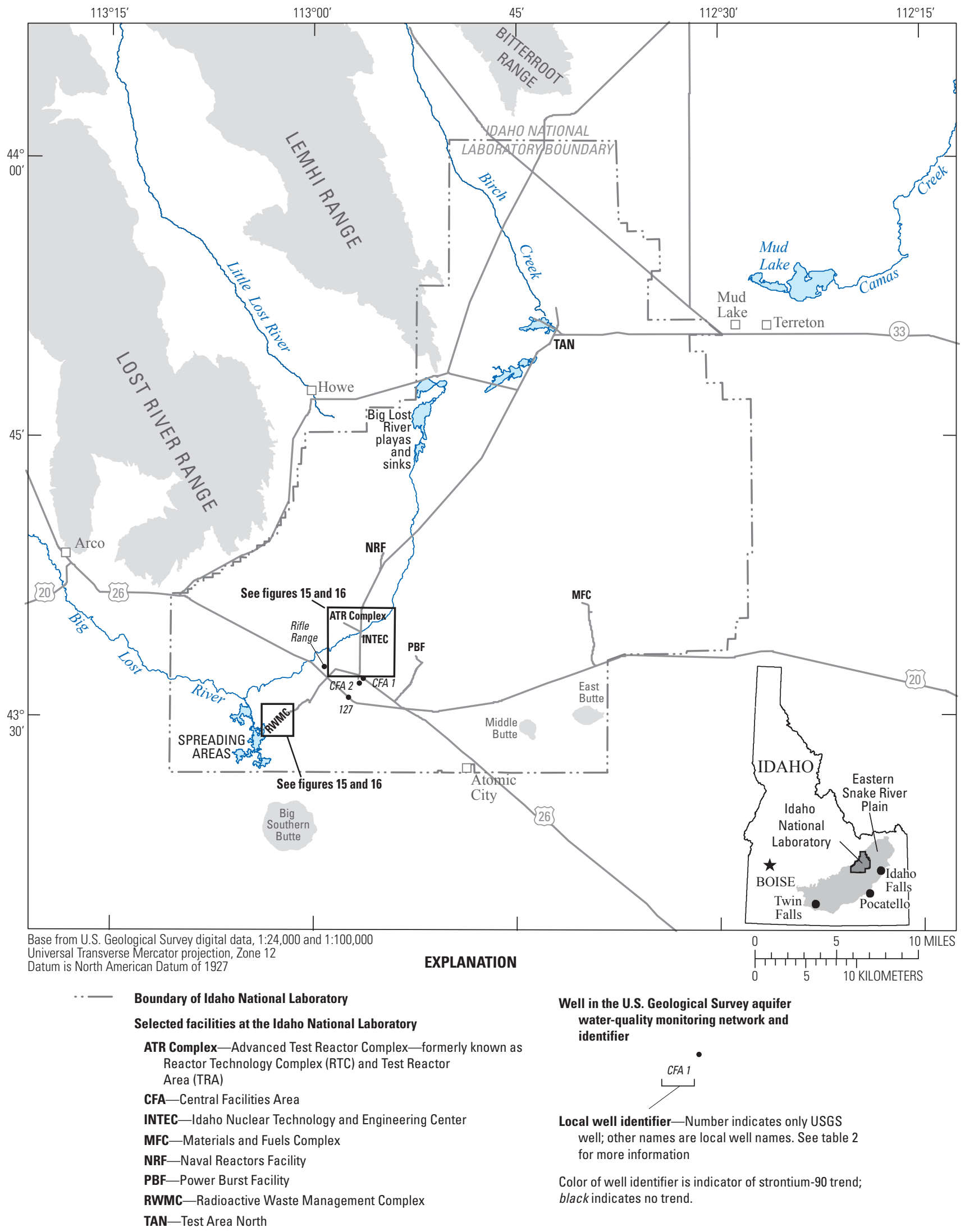

Figure 14. Areal distribution of strontium-90 trends in water from selected aquifer wells at and near the Idaho National Laboratory, Idaho. 


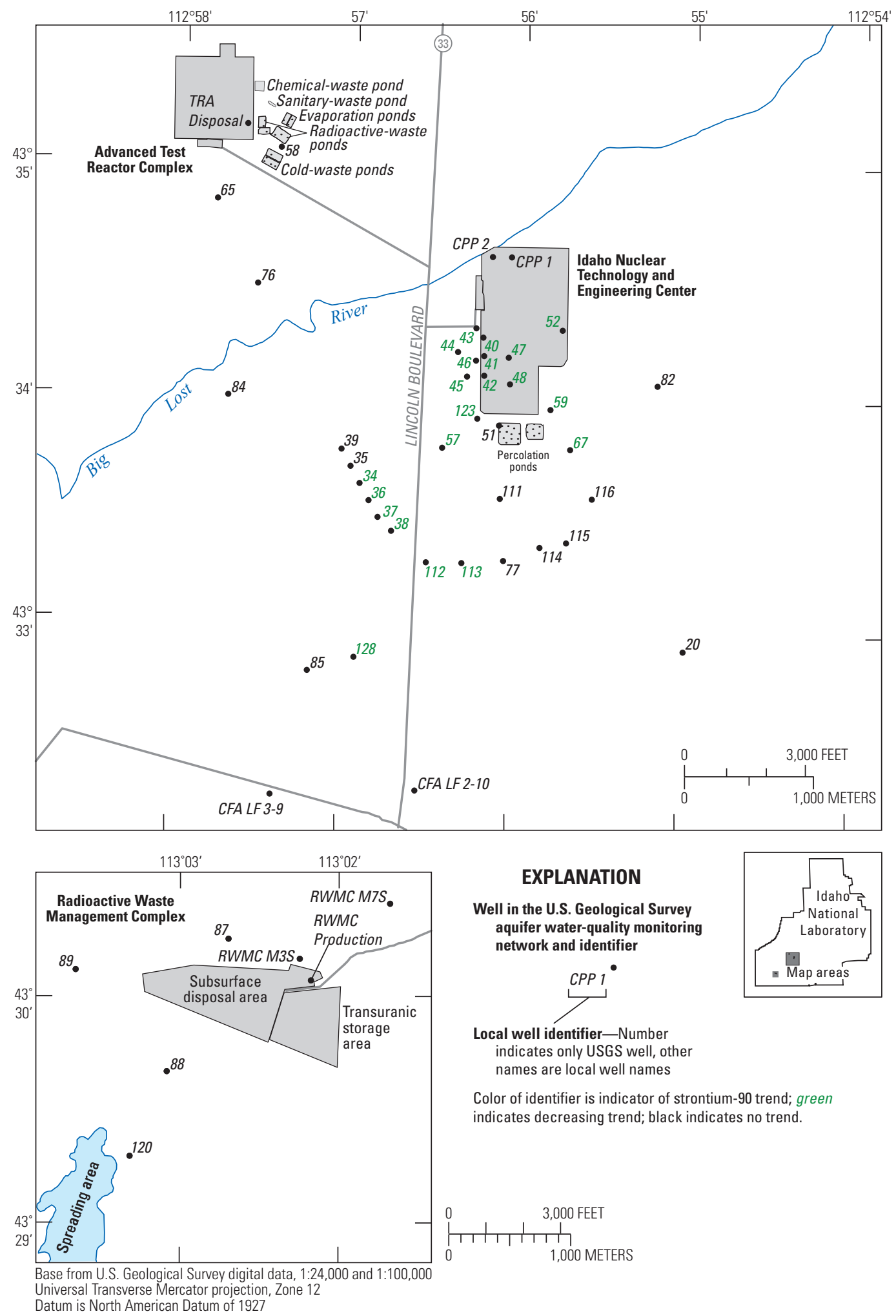

Figure 15. Areal distribution of strontium-90 trends in water from selected aquifer wells at the Advanced Test Reactor Complex, Idaho Nuclear Technology and Engineering Center, and the Radioactive Waste Management Complex, Idaho National Laboratory, Idaho. 


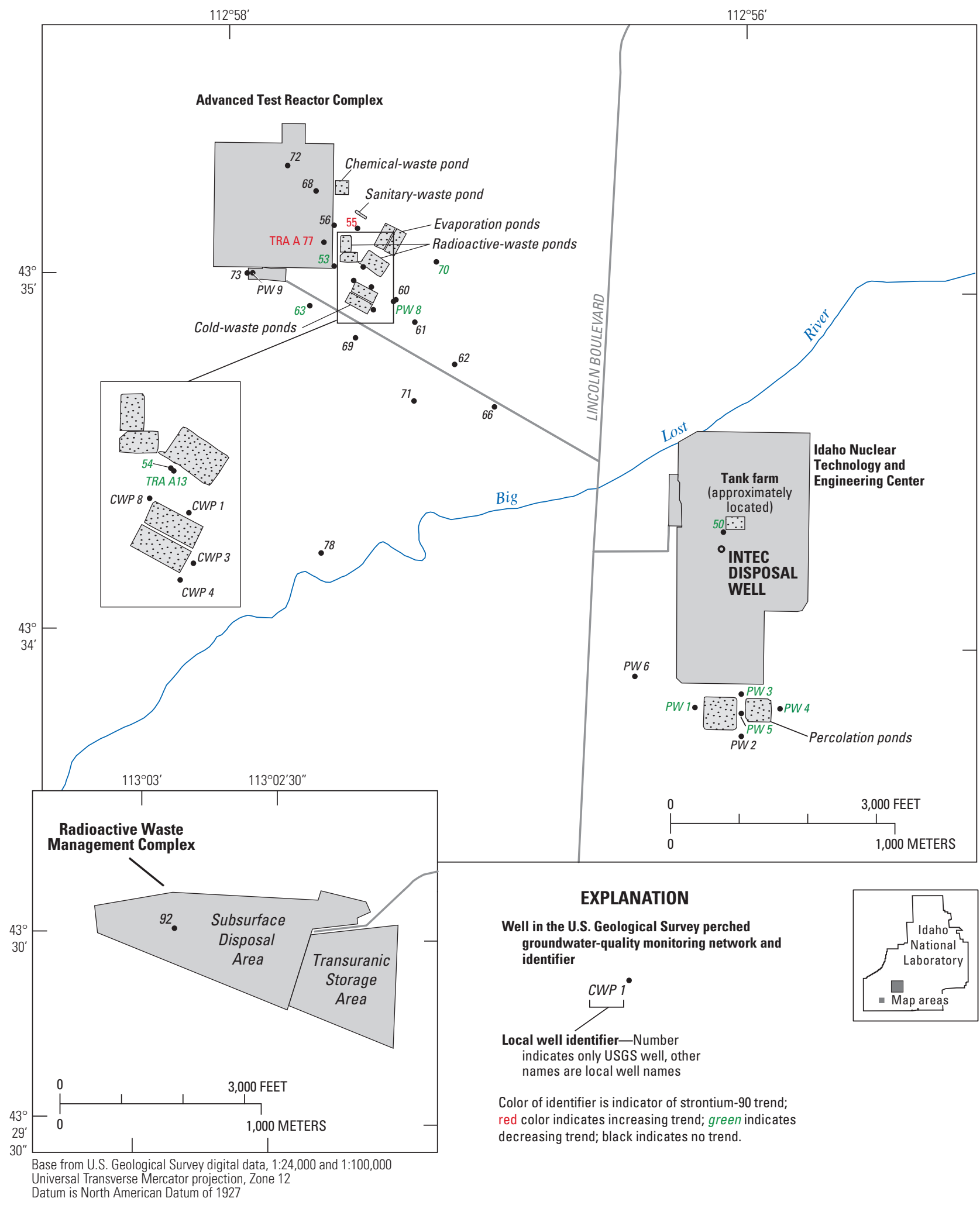

Figure 16. Areal distribution of strontium-90 trends in water from selected perched groundwater wells at the Advanced Test Reactor Complex, Idaho Nuclear Technology and Engineering Center, and the Radioactive Waste Management Complex, Idaho National Laboratory, Idaho. 


\section{Americium-241}

Americium-241 is a decay product of plutonium-241. Plutonium isotopes have been detected in wastewater discharged to the ESRP aquifer at the INL and in waste buried at the RWMC. The half-life of americium-241 is 432.7 years (Walker and others, 1989, p. 46). Water from 16 aquifer wells and 1 perched groundwater well were routinely sampled and analyzed for plutonium isotopes. The number of samples collected and the number of samples with concentrations greater than the reporting level are shown in table 6. Because americium-241 concentrations were less than the reporting levels for most samples, no trend analyses were done.

\section{Gross Alpha- and Beta-Particle Radioactivity}

Gross alpha- and beta-particle radioactivity is a measure of the total radioactivity emitted as alpha and beta particles during the radioactive decay process. The radioactivity usually is reported as if it occurred as one radionuclide. Gross alpha and beta measurements are used to screen for radioactivity in the aquifer as a possible indicator of groundwater contamination, but measurable concentrations also can occur from the natural decay of radioactive material in aquifer material. In 2008, the RESL increased the sensitivity of the analyses; therefore, concentrations greater than the reporting level for natural background concentrations in the aquifer were sometimes measured, although those same concentrations may not have been reported in the past.

Water samples have been routinely collected and analyzed for gross alpha- and beta-particle activity from 16 aquifer wells and 2 perched groundwater wells used in this study. The number of samples collected and the number of samples with concentrations greater than the reporting level are shown in table 6. Because gross alpha- and betaparticle activity are less than the reporting levels for most of the samples, no statistical trend analyses were done. Concentrations for a few of the samples were equal to or greater than the reporting level. Some of the samples with results at reporting levels of $3 \mathrm{~s}$ could be due to statistical fluctuations because the counting data are close to background concentrations. Other concentrations may represent background concentrations in the aquifer that have been detected because of increased sensitivity of the analyses, and some may be false positives (Davis, 2010, p. 28).

\section{Chloride}

Chloride has been discharged in wastewater at INL facilities since they were established. The background chloride concentration in water from the ESRP aquifer at the INL generally is about $15 \mathrm{mg} / \mathrm{L}$ (Robertson and others, 1974, p. 150). The secondary maximum contaminant level (MCL) for chloride in drinking water is $250 \mathrm{mg} / \mathrm{L}$ (U.S.
Environmental Protection Agency, 2013). Samples were routinely collected and analyzed for chloride from 63 aquifer wells and 33 perched groundwater wells used in this study. One aquifer well, RWMC M1SA, was not sampled for chloride. Two of the perched groundwater wells (CWP 5 and PW 7) had insufficient data to determine trends. Summary statistics and trends for chloride are given in table 7 (at back of report).

Chloride analyses were done by various laboratories until 1989, and most analyses since 1989 have been done at the NWQL. The datasets include some outlier values, and if the value did not seem reasonable compared with the specific conductance of the well, the outlier value was not used in the trend analysis. Chloride trends in water from aquifer wells at the INL are shown in figures 17 and 18 .

Of the 63 aquifer wells analyzed for statistically significant chloride concentration trends, 31 of these wells had a decreasing trend, 15 had an increasing trend, and 17 had no trend (table 7). Most wells near the INTEC and ATR Complex showed decreasing or no trends for chloride (fig. 18), probably the result of decreased disposal of wastewater and (or) discontinued use of the percolation ponds south of the INTEC and redirection of discharge to the new percolation ponds 2 mi southwest of the INTEC in 2002. Five aquifer wells south and southeast of the INTEC showed increasing chloride trends. Near the RWMC, most wells north of the facility showed increasing chloride trends (figs. 17 and $\underline{18}$ ). The statistically significant increasing trends in the wells southeast of INTEC are attributed to lower transmissivity for the part of the aquifer the wells sample. The lower transmissivity and subsequent slower movement of water may be an indication that wastewater from higher concentration disposal periods are still moving into the wells causing the concentrations to still be rising. The increasing concentrations of chloride in the RWMC area may be the result of chloride in wastes buried at RWMC moving into the aquifer, or from chloride in wastewater disposed at upgradient facilities finally reaching these wells.

Perched groundwater analyzed for statistically significant trends in chloride concentration showed that 11 perched groundwater wells had decreasing trends, 4 had increasing chloride concentration trends, and 18 had no trend (table 7). Most of the wells around the INTEC showed decreasing trends (fig. 19) and the trends are attributed to changes in disposal. Two of the wells (USGS 73 and PW 9) with increasing trends are in close proximity to each other and sample water from the same deep perched water zone, just south of the ATR Complex (fig. 19). Samples collected from the other two wells showed increasing trends (TRA A13 and A77) from a shallow perched zone. Chloride concentration trends generally were similar to the trend in specific conductance (appendixes B and $\underline{D}$ ).

Chloride (along with sodium, sulfate, and some nitrate) concentrations in wells USGS $34-39$ and USGS 112-113 may have been influenced by episodic recharge from the Big Lost River. Chloride, sodium, and sulfate concentrations seem to be inversely correlated with an increase in groundwater levels for wells USGS 35 and 39 (fig. 20). 


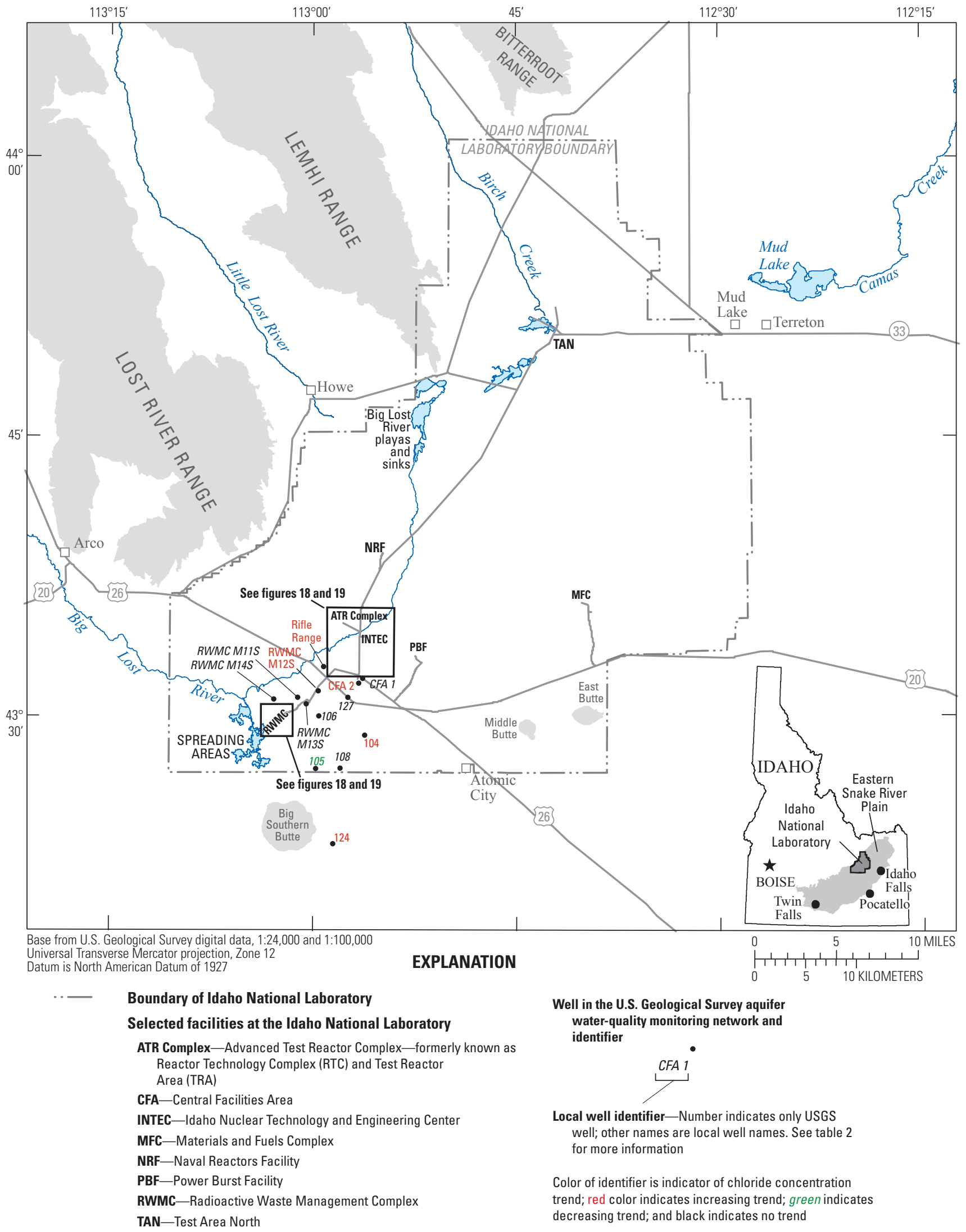

Figure 17. Areal distribution of chloride concentration trends in water from selected aquifer wells at and near the Idaho National Laboratory, Idaho. 


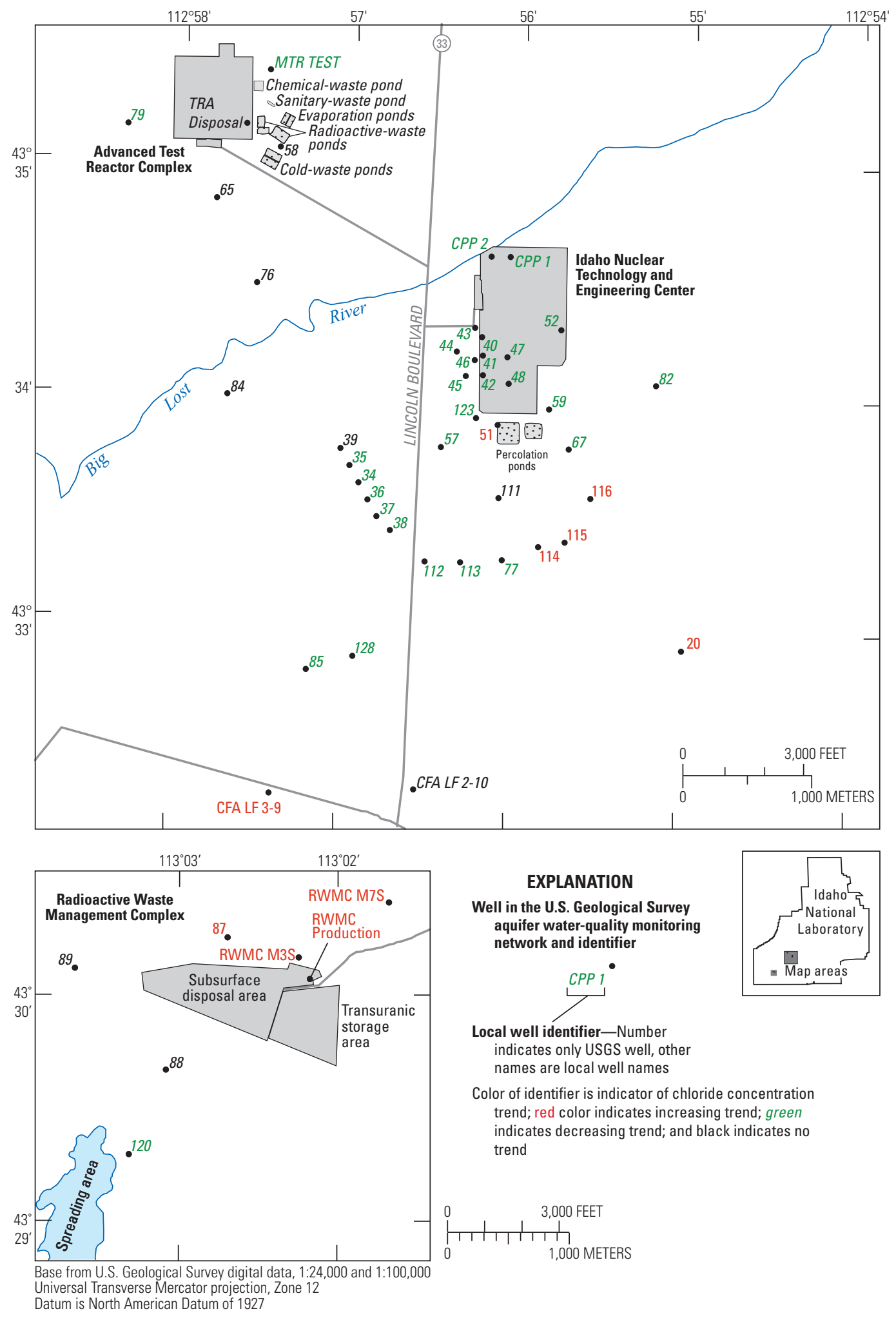

Figure 18. Areal distribution of chloride concentration trends in water from selected aquifer wells at the Advanced Test Reactor Complex, Idaho Nuclear Technology and Engineering Center, and the Radioactive Waste Management Complex, Idaho National Laboratory, Idaho. 


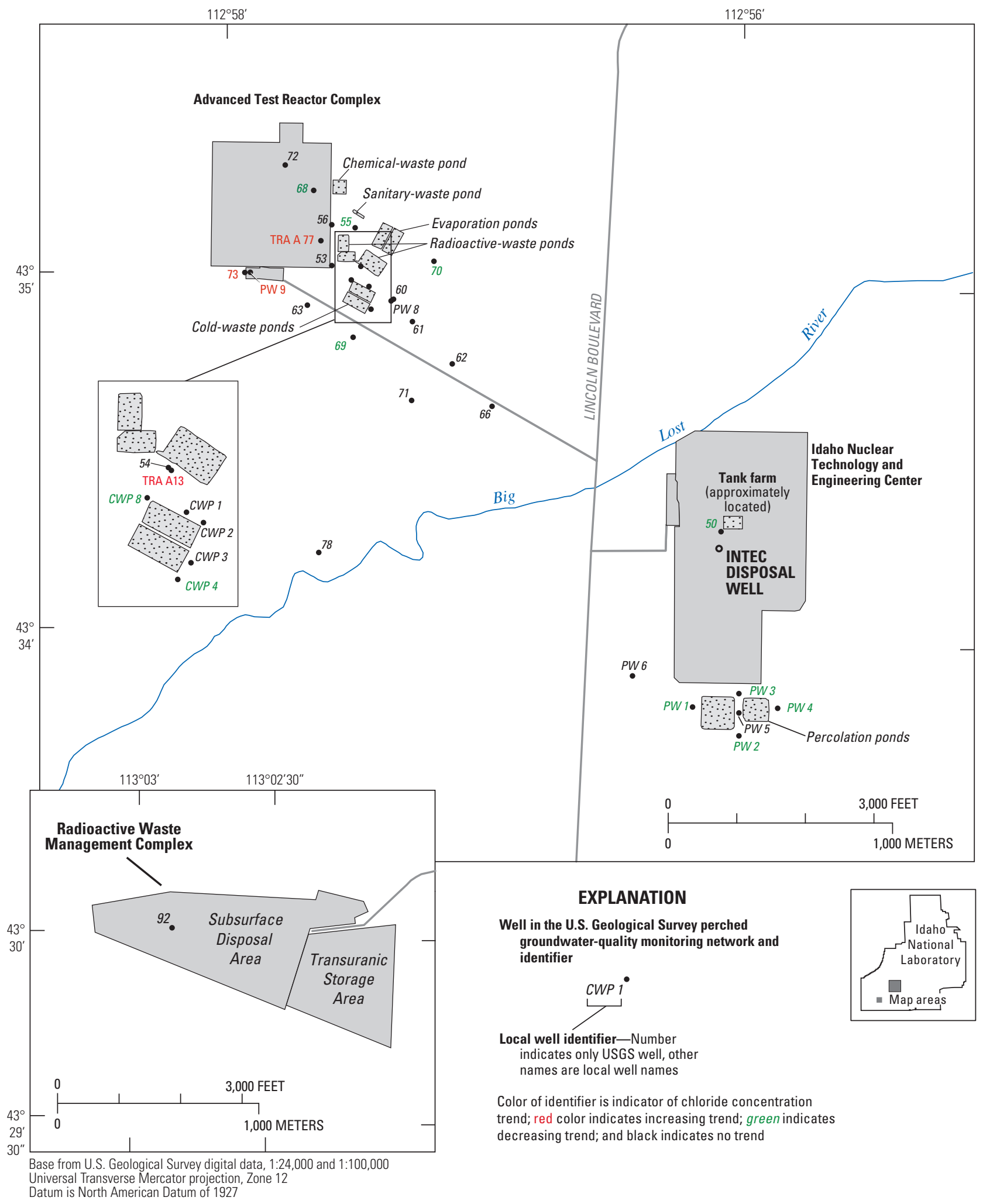

Figure 19. Areal distribution of chloride concentration trends in water from selected perched groundwater wells at the Advanced Test Reactor Complex, Idaho Nuclear Technology and Engineering Center, and the Radioactive Waste Management Complex, Idaho National Laboratory, Idaho. 


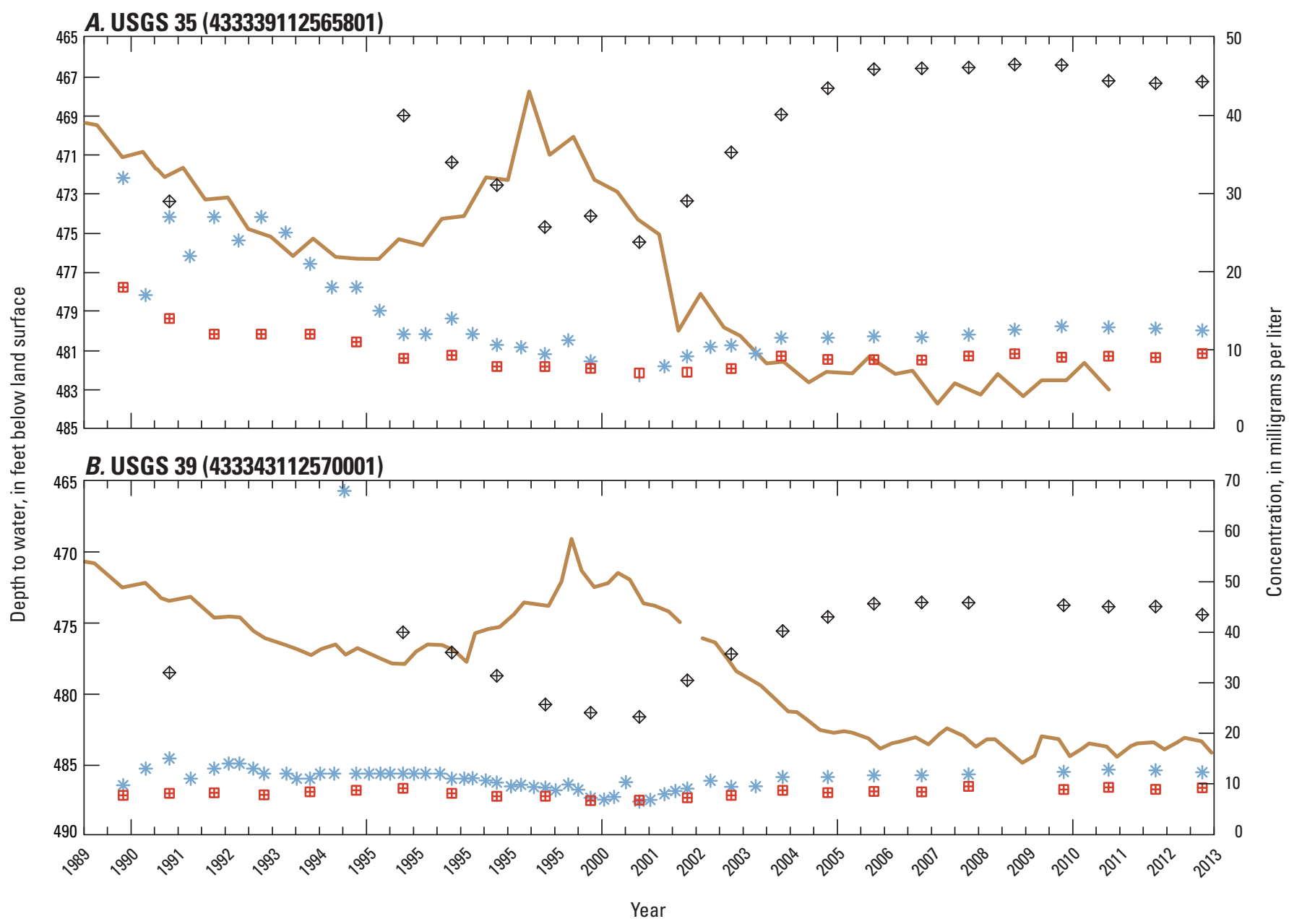

EXPLANATION

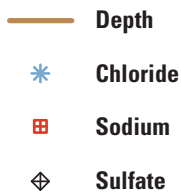

Figure 20. Fluctuations in chloride, sodium, and sulfate concentrations relative to water-level changes at wells $(A)$ USGS 35 and $(B)$ USGS 39 and $(C)$ changes in streamflow from the Big Lost River, Idaho. 

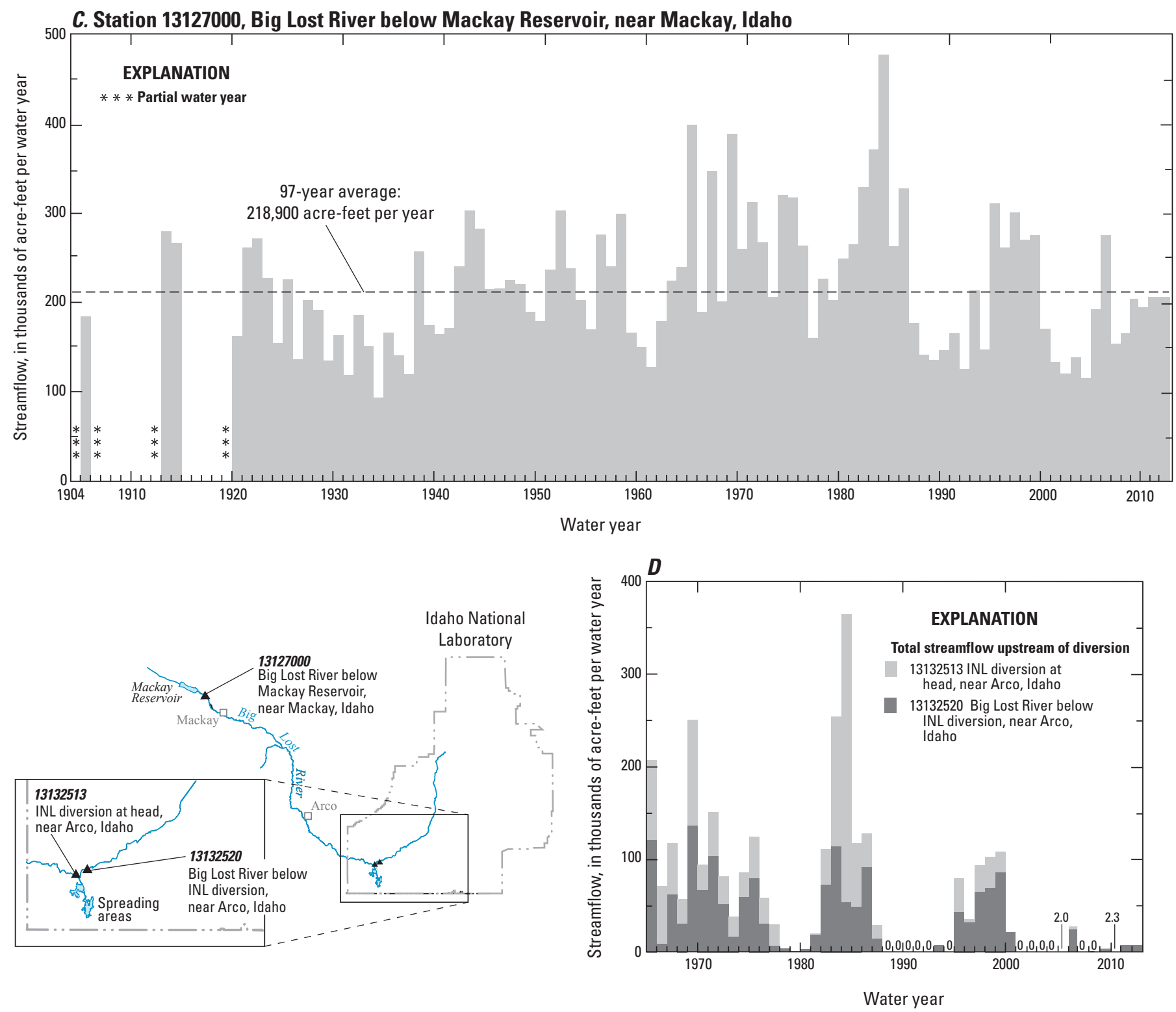

Figure 20.-Continued 
Wells USGS 34, 36, 38, and USGS 112-113 show similar patterns with concentrations decreasing during wet periods when there is more recharge from the Big Lost River and thus increasing groundwater levels, and increasing during dry periods, when there is no recharge from the Big Lost River (fig. 20). Although groundwater levels visually appear to have some effect, when using water level as a covariant in the statistical model, no significant effect on trend occurs (table 3 ).

\section{Sodium}

Sodium has been discharged in wastewater at INL facilities since they were established. The background concentration of sodium in water from the ESRP aquifer near the INL generally is less than $10 \mathrm{mg} / \mathrm{L}$ (Robertson and others, 1974 , p. 155). Samples were routinely collected and analyzed for sodium from 59 aquifer wells and 24 perched groundwater wells. Aquifer well CFA LF 3-9 was not analyzed for sodium, and wells RWMC M1SA, RWMC M3S, RWMC M7S, and USGS 128 had only one analysis each for sodium. Perched groundwater wells USGS 92, CWP 1, 2, 3, 5, and 8 were not analyzed for sodium, and wells CWP 4, PW 6, PW 7, TRA A 13, and TRA A 77 had insufficient data for trend analyses. Summary statistics and trends are given in table 7.

Sodium analyses were done by various laboratories until 1989 and most analyses since have been done at the NWQL. The datasets included some outlier values, and if the value did not seem reasonable compared with the specific conductance, the outlier value was not used in the trend analyses. Only analyses by the NWQL for 1989-2012 are included in the trend analyses. Sodium trends in water from aquifer wells and perched groundwater wells at the INL are shown in figures 21, $\underline{22}$, and $\underline{23}$.

Of the 59 aquifer wells analyzed for statistically significant sodium concentration trends, 22 wells showed a decreasing trend, 14 showed an increasing trend, and 23 showed no trend (figs. 21 and 22, table 7). Sodium hydrate was a predominant constituent in wastewater discharged to the chemical-waste infiltration pond at the ATR Complex (Davis, 2010). South and east of the ATR Complex, sodium showed increasing trends in a few wells (fig. 22). Sodium and chloride were two of the predominant chemical constituents in wastewater discharged at the INTEC (Pittman and others, 1988; Orr and Cecil, 1991; Bartholomay and others, 2000). South of the INTEC, trends in sodium generally were similar to trends in chloride, with the exception of well USGS 39, which had an increased sodium trend and no chloride trend. Some of the water from wells showing decreasing trends in chloride showed no trends in sodium at the INTEC (figs. 18 and 22). Sodium and chloride were predominant constituents discharged in wastewater at the Central Facilities Area (CFA) (Bartholomay and others, 2000). Some wells downgradient of the CFA and near the southern boundary of the INL showed increasing trends in sodium, whereas there was no trend in chloride (figs. 17 and 21). The increasing trend for sodium could be due to the long-term disposal of wastewater at upgradient facilities. The lack of trend for chloride could be because it is more mobile in groundwater (Hem, 1989, p. 118) than sodium and, thus, more dispersed in the aquifer system. The increasing sodium trend in the Rifle Range well is likely the result of the redirection of discharge from the INTEC to the new percolation ponds $2 \mathrm{mi}$ southwest of the INTEC. Five perched groundwater wells analyzed for sodium trends had decreasing trends, 1 (USGS 71) had an increasing trend, and 18 had no trend (fig. 23, table 7).

\section{Fluoride}

Fluoride was discharged in wastewater to percolation ponds at the INTEC during 1971-98 (Bartholomay and others, 2000). Background concentrations of fluoride in the ESRP aquifer in the southwestern part of the INL range from about 0.1 to $0.3 \mathrm{mg} / \mathrm{L}$ (Robertson and others, 1974, p. 75). The MCL for fluoride in drinking water is $4 \mathrm{mg} / \mathrm{L}$ (U.S. Environmental Protection Agency, 2013). Samples were routinely collected and analyzed for fluoride from four wells used in this study. Summary statistics and trends calculated are given in table 7 .

Fluoride concentration trends for four aquifer wells (CPP 1, USGS 34, 38, and 77) near the INTEC are shown in table 7. Other aquifer and perched groundwater wells were sampled sporadically for fluoride; however, data from those wells were not sufficient to determine statistically significant trends. For the four aquifer wells with sufficient data, two (USGS 38 and USGS 77) showed increasing trends and two (CPP 1 and USGS 34) showed no trend. All fluoride concentrations were within the background range of 0.1 to $0.3 \mathrm{mg} / \mathrm{L}$, indicating that wastewater disposal has not had an appreciable effect on fluoride concentrations in the ESRP aquifer near the INTEC (Davis and others, 2013). The increasing trends probably are due to changes in the reporting standards by the NWQL and not the result of actual changes in the concentrations of fluoride in the aquifer.

\section{Sulfate}

Sulfate has been discharged in wastewater at the INL facilities since they were established. The background sulfate concentrations in water from the ESRP aquifer in the southcentral part of the INL range from about 10 to $40 \mathrm{mg} / \mathrm{L}$ (Robertson and others, 1974, p. 72). The secondary MCL for sulfate in drinking water is $250 \mathrm{mg} / \mathrm{L}$ (U.S. Environmental Protection Agency, 2013). Sulfate was routinely analyzed for water samples from 48 aquifer wells and 22 perched groundwater wells used in this study. 


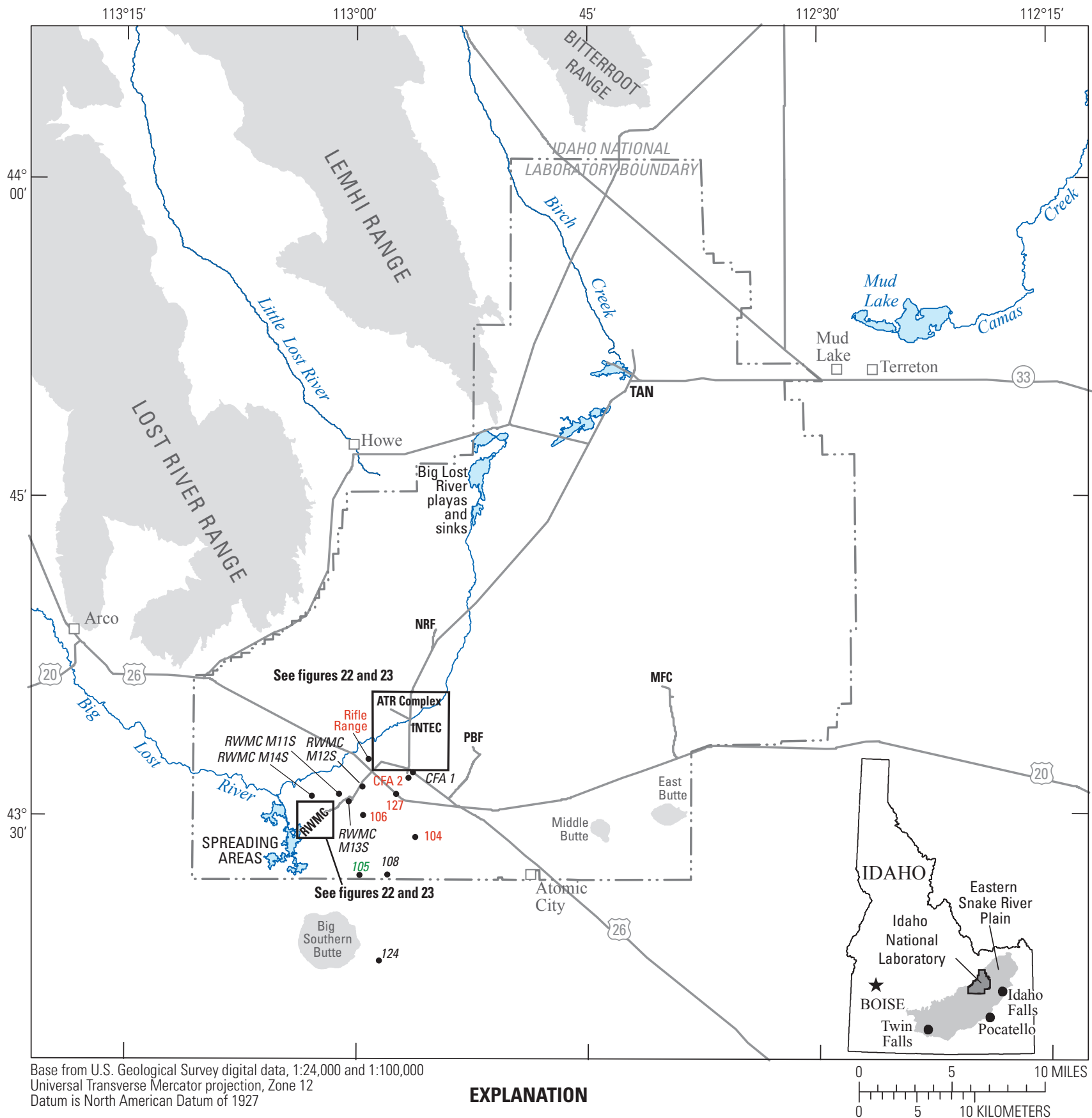

.. - Boundary of Idaho National Laboratory

\section{Selected facilities at the Idaho National Laboratory}

ATR Complex-Advanced Test Reactor Complex-formerly known as Reactor Technology Complex (RTC) and Test Reactor Area (TRA)

CFA-Central Facilities Area

INTEC_-Idaho Nuclear Technology and Engineering Center

MFC-Materials and Fuels Complex

NRF-Naval Reactors Facility

PBF-Power Burst Facility

RWMC-Radioactive Waste Management Complex

TAN-Test Area North Well in the U.S. Geological Survey aquifer
water-quality monitoring network and identifier

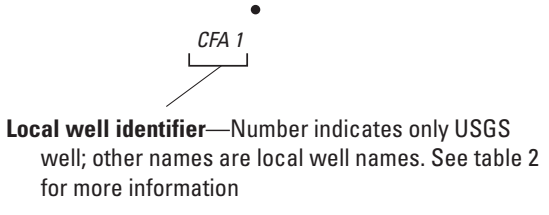

Color of identifier is indicator of sodium concentration trend; red color indicates increasing trend; green indicates decreasing trend; and black indicates no trend

Figure 21. Areal distribution of sodium concentration trends in water from selected aquifer wells at and near the Idaho National Laboratory, Idaho. 


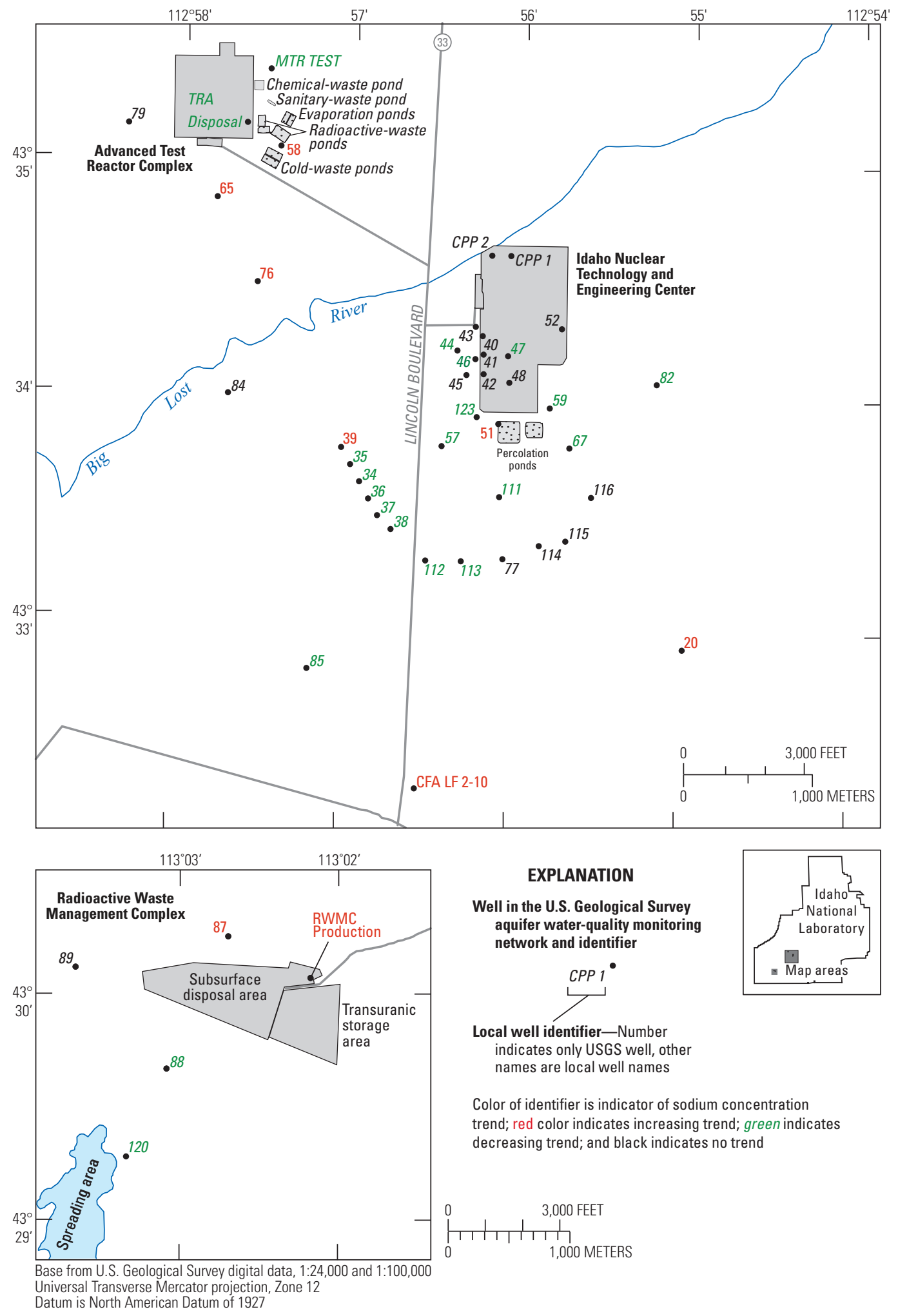

Figure 22. Areal distribution of sodium concentration trends in water from selected aquifer wells at the Advanced Test Reactor Complex, Idaho Nuclear Technology and Engineering Center, and the Radioactive Waste Management Complex, Idaho National Laboratory, Idaho. 


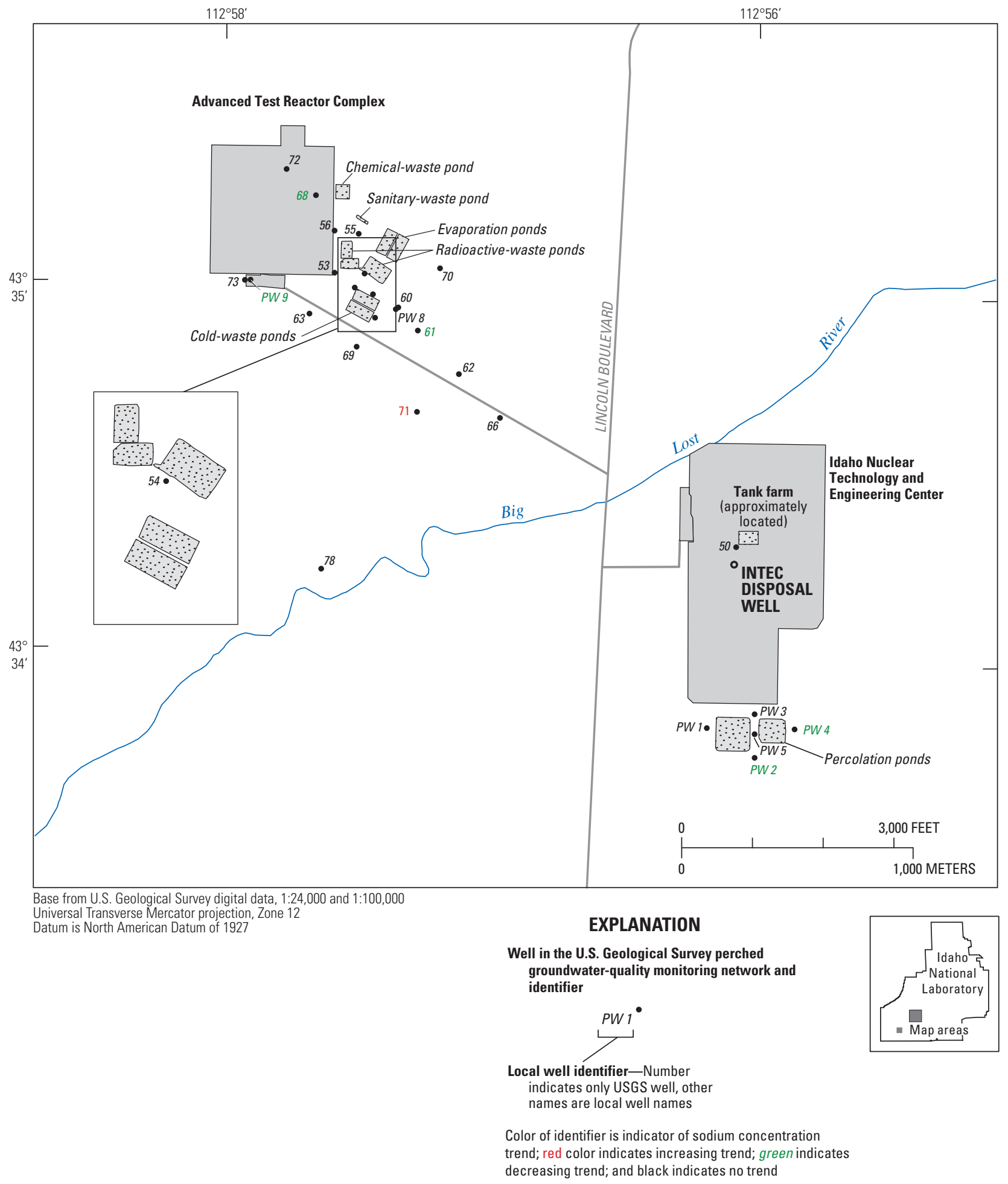

Figure 23. Areal distribution of sodium concentration trends in water from selected perched groundwater wells at the Advanced Test Reactor Complex, Idaho Nuclear Technology and Engineering Center, and the Radioactive Waste Management Complex, Idaho National Laboratory, Idaho. 
Sulfate analyses were done by various laboratories until 1989 , and most analyses since then have been done at the NWQL. The datasets include some outlier values, and if the value did not seem reasonable compared with the specific conductance of the well, the outlier value was not used in the trend analyses. Sulfate trends and summary statistics for water from sites at the INL from 1989 to 2012 are shown in figures 24-26, table 7, and appendix D.

Forty-eight aquifer wells were analyzed for statistically significant sulfate concentration trends; 24 had decreasing trends, 13 had increasing trends, and 11 had no trend. Most aquifer wells that had increasing trends were located downgradient of the INTEC or ATR Complex, in the general direction of regional groundwater flow toward the southwest. The increasing trend in these wells may be attributable to disposal of sulfate-enriched wastewater at the ATR Complex cold and chemical waste ponds. As with chloride and sodium, some wells appear to be affected by episodic recharge from the Big Lost River, which dilutes sulfate concentrations in the groundwater (fig. 20). Closer to the facilities, sulfate trends either decreased or there was no trend (figs. 24 and $\underline{25}$, table 7). Most perched groundwater wells near the INTEC and ATR Complex showed decreasing or no trends, with the exception of well PW 4, east of the percolation ponds at the INTEC, which showed an increasing trend (fig. 26).

\section{Nitrite Plus Nitrate (as N)}

Wastewater containing nitrate was injected into the ESRP aquifer through the INTEC disposal well from 1952 to February 1984, and was discharged to the INTEC percolation ponds after February 1984 (Orr and Cecil, 1991). Because nitrite analyses indicate that almost all nitrite plus nitrate concentrations are nitrate (as N), concentrations will be referred to as nitrate in this report. Background concentrations of nitrate in groundwater not affected by wastewater disposal from INL facilities generally are less than $1 \mathrm{mg} / \mathrm{L}$ (Robertson and others, 1974, p. 73). The MCL for nitrate in drinking water is $10 \mathrm{mg} / \mathrm{L}$ (U.S. Environmental Protection Agency, 2013). Nitrate was routinely analyzed for water samples from 59 aquifer wells and 1 perched groundwater well. Nitrate trends and summary statistics for water from wells at the INL for 1989-2012 are shown in figures 27-28, table 7, and appendix D.

Fifty-nine aquifer wells were analyzed for trends in nitrate concentrations. Of those, 28 showed a decreasing trend, 8 showed an increasing trend, and 23 showed no trend (figs. 27 and 28 ). As was shown for chloride, sodium, and sulfate for wells near the Big Lost River, the nitrate concentrations decreased during periods when water levels were higher, probably due to recharge and dilution from Big Lost River seepage, and increased when recharge from Big Lost seepage was less (Bartholomay and others, 2012) (appendix D). Most of the wells around INTEC showed decreasing or no trend, which probably is due to discontinued use of the disposal well in 1984 and the percolation ponds in 2002. The increasing concentration in USGS 67 (fig. 28) is puzzling and may indicate another source of contamination rather than the percolation ponds. Only one perched groundwater well (USGS 50) was analyzed for a trend in nitrate. Results for this well indicated a decreasing trend (table 7) which probably was due to discontinued use of the INTEC disposal well in 1984.

\section{Orthophosphate (as P)}

Orthophosphate (as P) has not been a major constituent discharged in wastewater at the INL; only about $9 \mathrm{~kg}$ was discharged in liquid effluent at the INL from 1971 to 1998 (French and others, 1999). Water samples from 59 aquifer wells and 1 perched groundwater well were routinely analyzed for orthophosphate (as P). Summary statistics and trends for orthophosphate (as P) are given in table 7.

Orthophosphate (as P) concentrations were near or less than the reporting levels for most of the samples in most of the wells. Of the 59 aquifer wells analyzed for statistically significant orthophosphate concentration trends, 26 had increasing trends and $33 \mathrm{had}$ no trend. The increasing trends could be due to anthropogenic influence from activities upgradient of the INL or could be due to changes in data reporting by the NWQL rather than actual changes in concentrations in the aquifer. Prior to 2003, results were rounded to the nearest tenth and since 2003, results are rounded to the nearest hundredth of a milligram per liter. The only perched aquifer well analyzed for an orthophosphate trend at the INTEC was USGS 50; results indicated no trend (table 7).

\section{Trace Elements}

A suite of trace elements including aluminum, antimony, arsenic, barium, beryllium, cadmium, cobalt, copper, lead, manganese, molybdenum, nickel, silver, uranium, and zinc were routinely collected from two wells (USGS 65 and USGS 84). Water samples were analyzed for chromium from 25 aquifer wells and 21 perched groundwater wells. Samples for selenium analysis were collected from wells USGS 65 and USGS 84 downgradient of the ATR Complex. Selenium was considered a constituent of concern in the 1993 INL groundwater-monitoring plan at that facility (Sehlke and Bickford, 1993). Neither well had sufficient data for statistical analysis of beryllium and silver.

Results of trend tests for trace element concentrations are shown in appendix D. Summary statistics and trend test results are given in table 7. Well USGS 65 showed a decreasing trend for barium, cadmium, cobalt, lead, and zinc, increasing trends for arsenic, molybdenum, and uranium, and no trend for aluminum, antimony, copper, manganese, nickel, and selenium. Well USGS 84 showed decreasing trends for cadmium, cobalt, copper, lead, nickel, and zinc, an increasing trend for arsenic, and no trend for aluminum, antimony, barium, manganese, molybdenum, selenium and uranium. 


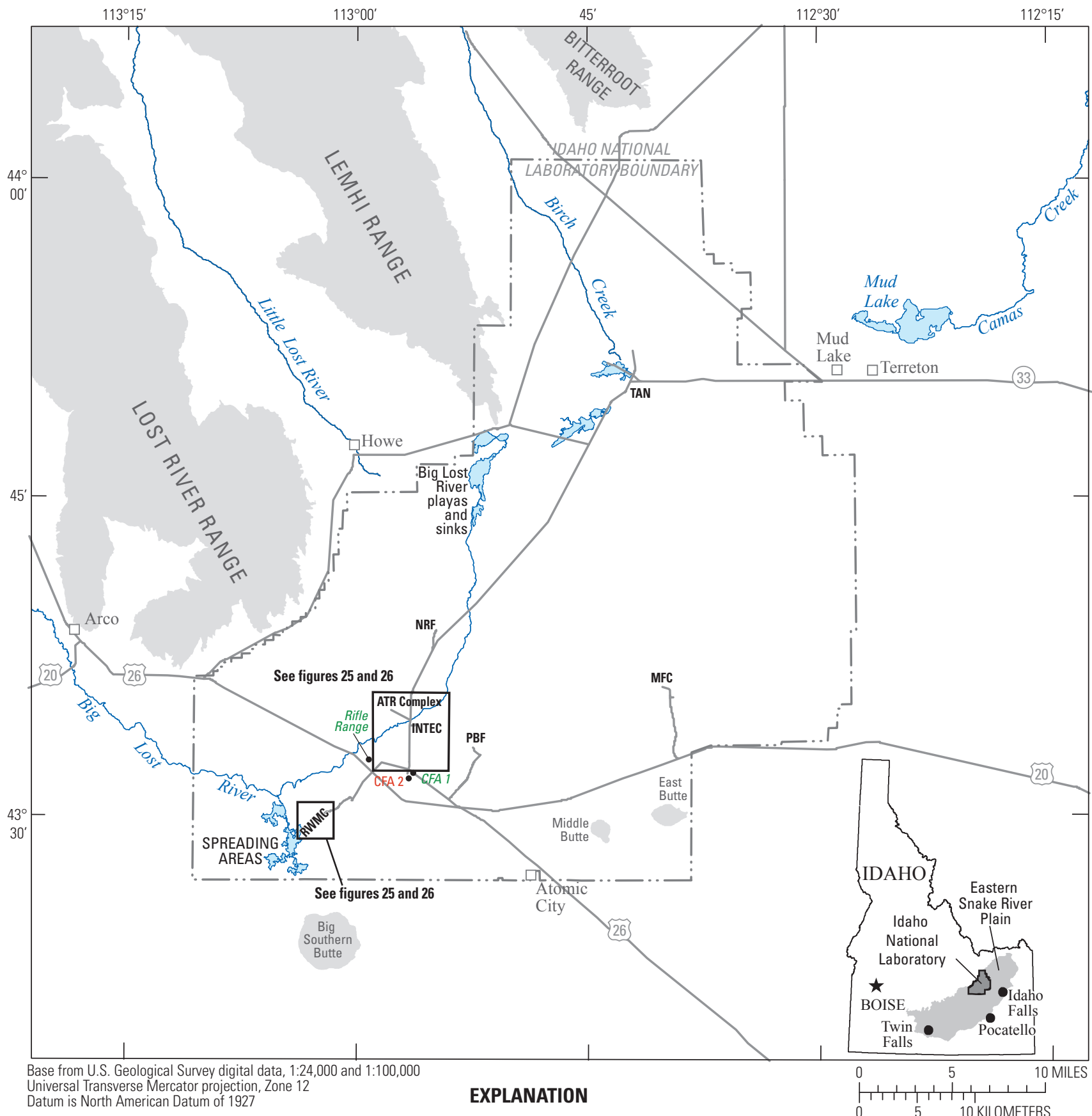

Universal Transverse Mercator projection, Zone 12

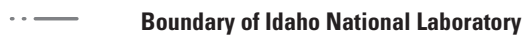

\section{Selected facilities at the Idaho National Laboratory}

ATR Complex-Advanced Test Reactor Complex-formerly known as Reactor Technology Complex (RTC) and Test Reactor Area (TRA)

CFA-Central Facilities Area

INTEC_-Idaho Nuclear Technology and Engineering Center

MFC-Materials and Fuels Complex

NRF-Naval Reactors Facility

PBF-Power Burst Facility

RWMC-Radioactive Waste Management Complex

TAN-Test Area North

Well in the U.S. Geological Survey aquifer water-quality monitoring network and identifier

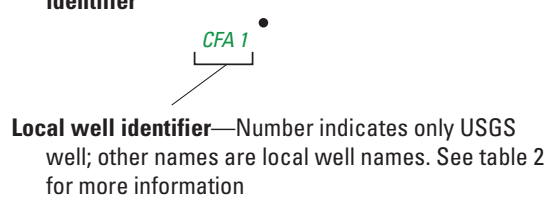

Color of identifier is indicator of sulfate concentration trend; red color indicates increasing trend; and green indicates decreasing trend

Figure 24. Areal distribution of sulfate concentration trends in water from selected wells at and near the Idaho National Laboratory, Idaho. 


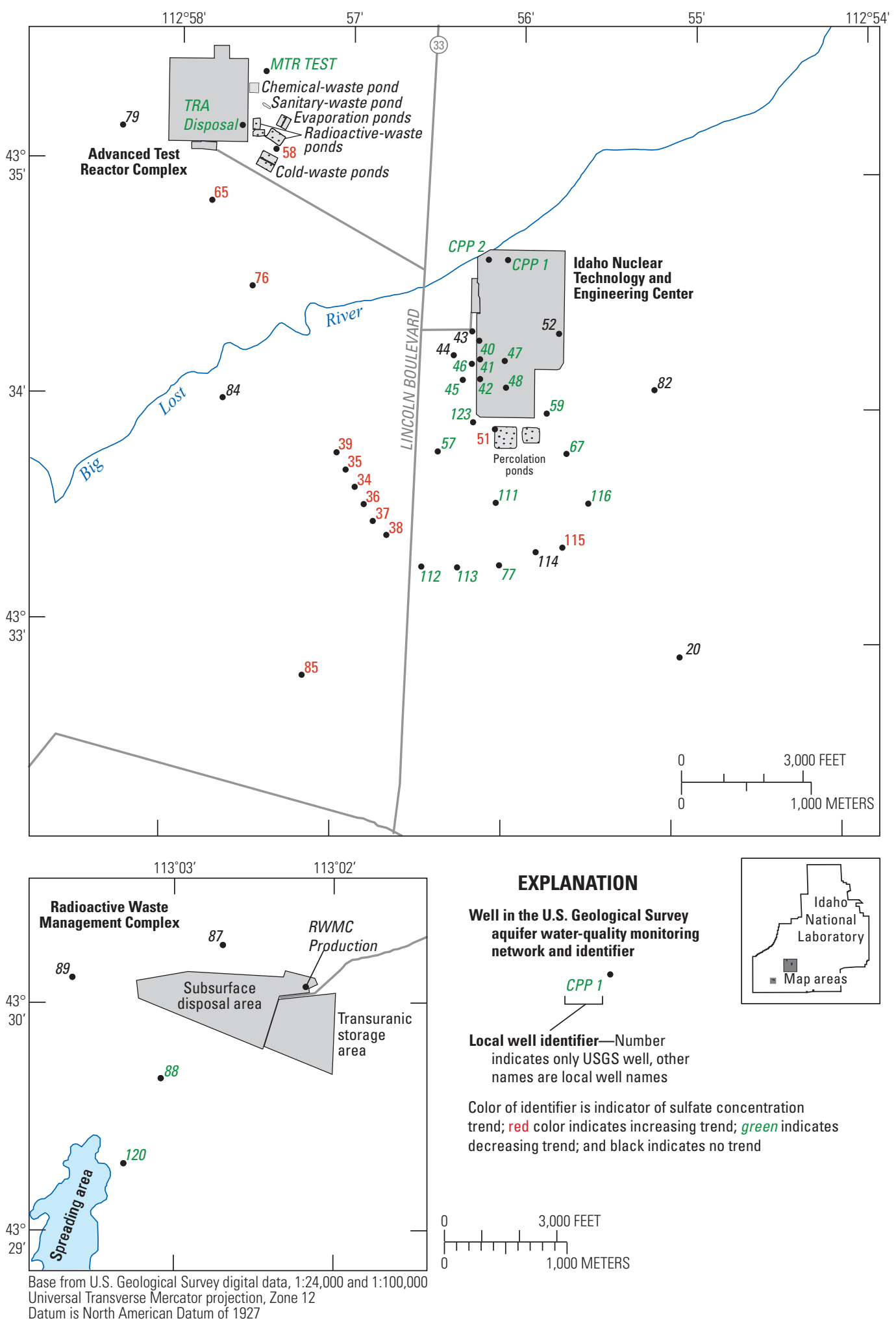

Figure 25. Areal distribution of sulfate concentration trends in water from selected aquifer wells at the Advanced Test Reactor Complex, Idaho Nuclear Technology and Engineering Center, and the Radioactive Waste Management Complex, Idaho National Laboratory, Idaho. 


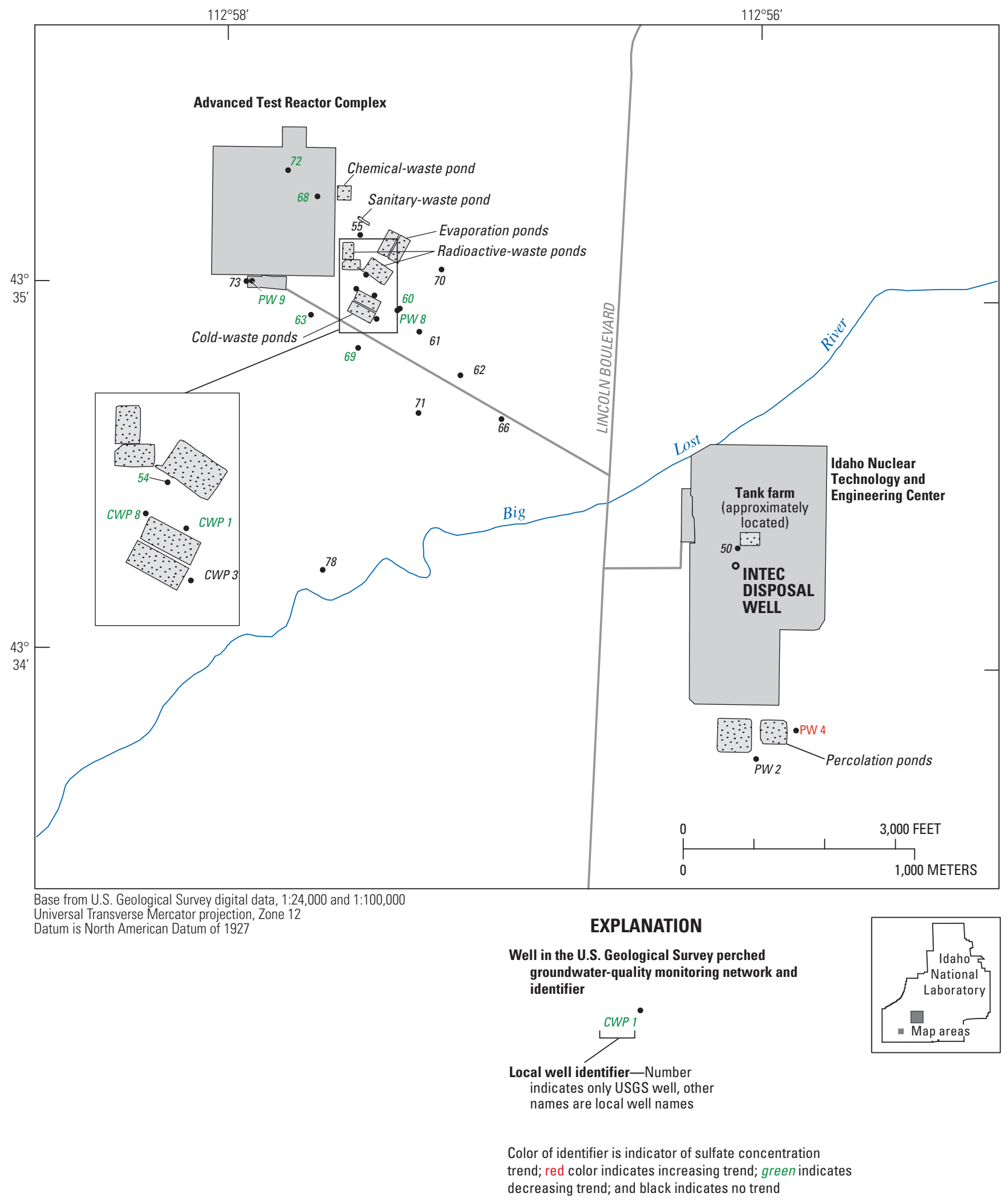

Figure 26. Areal distribution of sulfate concentration trends in water from selected perched groundwater wells at the Advanced Test Reactor Complex, Idaho Nuclear Technology and Engineering Center, and the Radioactive Waste Management Complex, Idaho National Laboratory, Idaho. 


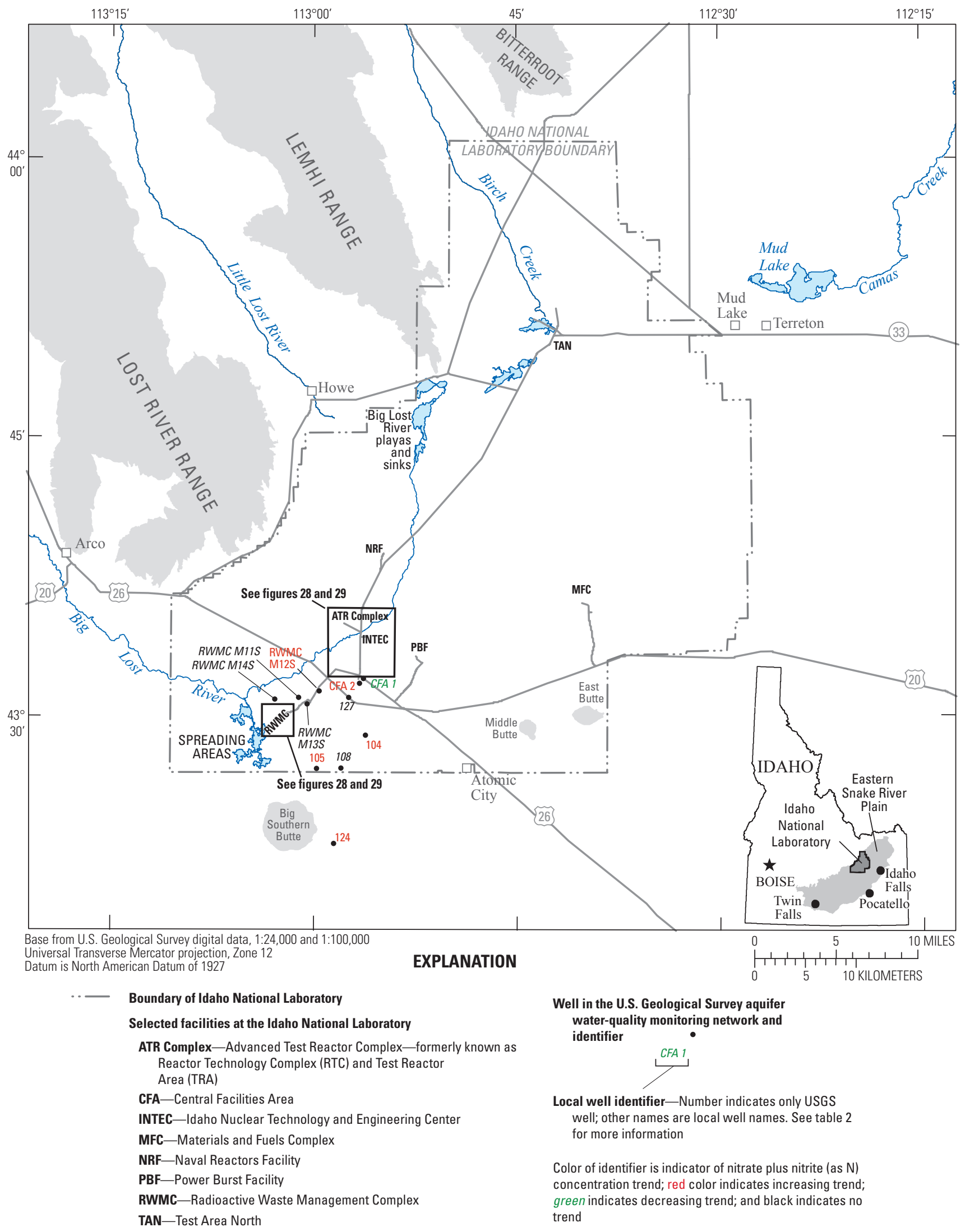

Figure 27. Areal distribution of nitrite plus nitrate (as N) concentration trends in water from selected wells at and near the Idaho National Laboratory, Idaho. 


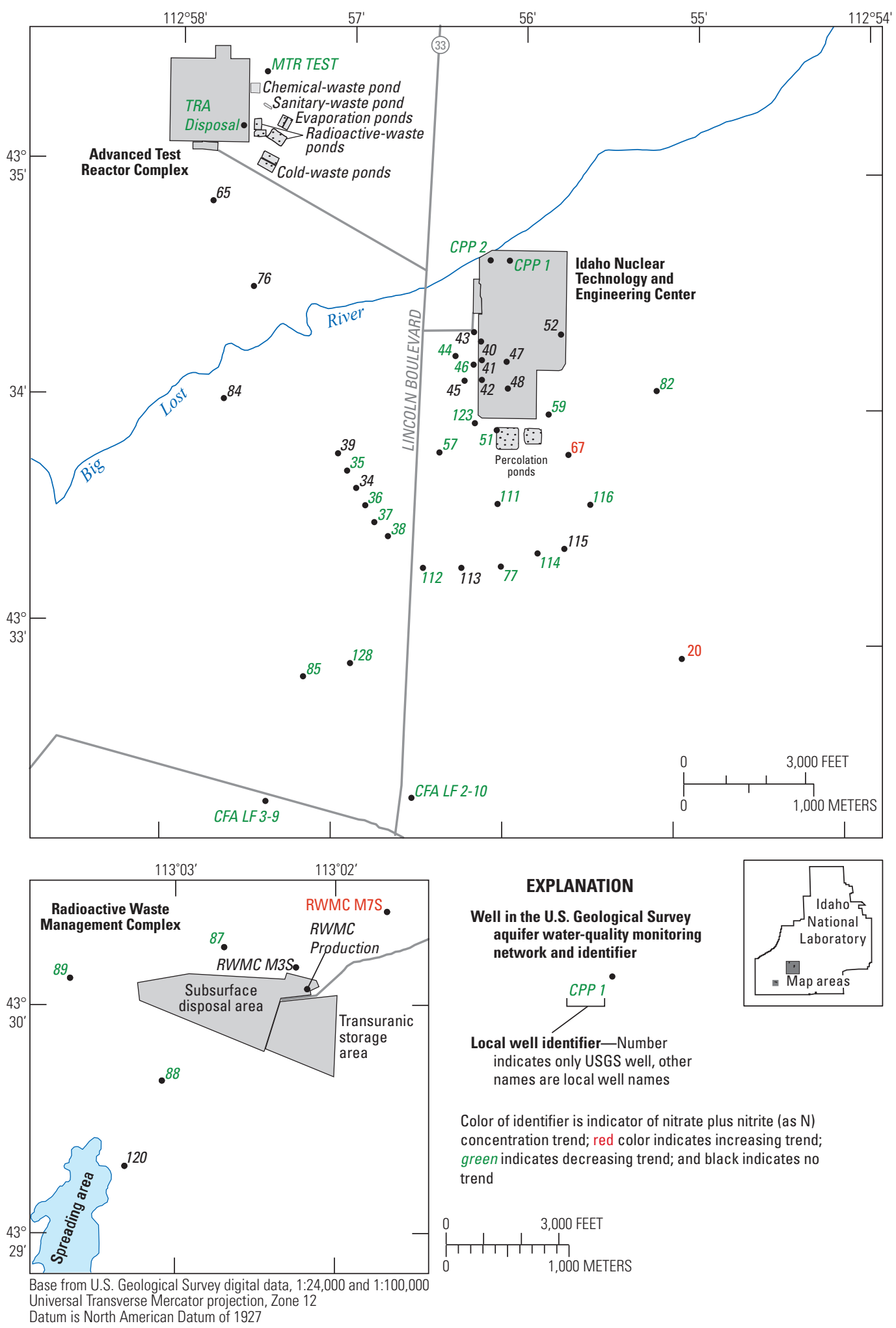

Figure 28. Areal distribution of nitrite plus nitrate (as N) concentration trends in water from selected aquifer wells at the Advanced Test Reactor Complex, Idaho Nuclear Technology and Engineering Center, and the Radioactive Waste Management Complex, Idaho National Laboratory, Idaho. 


\section{Chromium}

Disposal of chromium in wastewater has occurred at the ATR Complex, INTEC, and the Power Burst Facility (PBF) (Davis, 2010, p. 37). Background concentrations of chromium in water from the ESRP aquifer at the INL range from 2 to $3 \mu \mathrm{g} / \mathrm{L}$ (Orr and others, 1991, p. 41). The MCL for chromium in drinking water is $100 \mu \mathrm{g} / \mathrm{L}$ (U.S. Environmental Protection Agency, 2013). Water samples were routinely collected and analyzed for chromium from 25 aquifer wells and 21 perched groundwater wells. Summary statistics and trend test results for chromium concentrations are shown in table 7 and appendix D.

Of the 25 aquifer wells analyzed for statistically significant chromium concentration trends, 8 showed decreasing trends, 3 showed increasing trends, and 14 showed no trend. The three wells that showed increasing trends (CPP 1, USGS 34, and USGS 38) are located at or just downgradient of the INTEC. One well downgradient of the ATR Complex (USGS 65) showed a decreasing trend. Most of the other wells showing decreasing trends (Rifle Range Well, CFA LF- 2-10, RWMC M12S, RWMC M14S, USGS 77, USGS 87, and USGS 127) are near the CFA and the RWMC.

Of the 21 perched groundwater wells analyzed for chromium, 13 showed a decreasing trend, 1 well (USGS 68, at the ATR Complex) showed an increasing trend, and 7 showed no trend. All of the perched groundwater wells showing decreasing trends (CWP 3, PW 8-9, USGS 54-55, USGS 60-63, USGS 70-71, USGS 73, and USGS 78) are south or southeast of the ATR Complex. Decreasing trends in chromium concentrations in this area probably are due to discontinued disposal at the ATR complex.

\section{Total Organic Carbon}

Total organic carbon (TOC) is used as a general indicator of groundwater contamination and as a screen for other organic compounds in the aquifer. As part of the INL groundwater-monitoring program adopted in 1994, the USGS began collecting and analyzing water from several wells at the INL for TOC. Water samples were routinely analyzed for TOC from 15 aquifer wells but no water samples from perched groundwater wells were analyzed. Summary statistics and trend test results for TOC concentrations are shown in table 7 and appendix D. Four wells near the RWMC (RWMC M11S, RWMC M12S, RWMC M13S, and RWMC M14S) showed decreasing trends for TOC; no wells showed increasing trends, and 11 wells had no trend.

\section{Volatile Organic Compounds}

Volatile organic compounds (VOCs) are present in water from the ESRP aquifer because of historical waste-disposal practices at the INL. The VOCs were used for degreasing, decontamination, and other activities at INL facilities (Mann and Knobel, 1987, p. 1). An estimated 88,400 gal of organic waste was buried before 1970 in the SDA at the RWMC (Mann and Knobel, 1987, p. 1). These buried organic wastes included about 24,400 gal of carbon tetrachloride; 39,000 gal of lubricating oil; and about 25,000 gal of other organic compounds, including trichloroethane, trichloroethylene, perchloroethylene, toluene, and benzene. VOC concentrations for nine aquifer wells were analyzed for trends. At other aquifer wells, data were not sufficient to evaluate concentration trends, or the concentrations were all less than the reporting level. Concentration trends in aquifer wells with VOC data are given in table 8 (at back of report) and appendix E.

Historically, concentrations of VOCs in water samples from several wells at and near the RWMC exceeded the reporting levels (Bartholomay and others, 2000). However, concentrations for all VOCs except carbon tetrachloride were less than the MCL for drinking water (U.S. Environmental Protection Agency, 2013). Trend test results for carbon tetrachloride concentrations in water from the RWMC Production Well (appendix E) indicate a statistically significant increase in concentrations has occurred since 1987 (table 8 and appendix E). Concentrations have routinely exceeded the MCL for carbon tetrachloride in drinking water $(5 \mu \mathrm{g} / \mathrm{L})$ since 1998.

Davis and others (2013) indicated that more recent data collected since 2005 may be showing indications that concentrations are leveling off in the RWMC Production well. To further test this statement, a trend analyses was run on the dataset from 2005 through 2012 (fig. 29). The trend test on that dataset had a p-value of 0.054 , and still shows a positive increase, but the trend is not considered significant using the criteria for this report. The lack of a more recent significant increasing trend may indicate that engineering practices designed to reduce VOC concentration movement to the aquifer are having a positive effect. The RWMC Production well also had increasing trends for trichloroethene, trichloromethane, tetrachloroethene, 1,1,1-trichloroethane, and tribromomethane (table 7, appendix E). During 2009-11, water from well USGS 87, just north of the RWMC (fig. 3), had detectable concentrations of carbon tetrachloride, and exceeded the MCL for the first time in 2011 (Davis and others, 2013). Concentrations of carbon tetrachloride from this well have had an increasing trend since 1987 (table 8, appendix E). Well USGS 87 also had increasing concentration trends for trichloroethene, trichloromethane, dichlorodifluoromethane, but not a significant trend for 1,1,1-trichloroethane and tetrachloroethene. Well USGS 120, south of the RWMC (fig. 3), had increasing concentration trends of carbon tetrachloride and trichloromethane and no significant trends for tetrachloroethene, 1,1,1-trichloroethane, and trichloroethene (table 8, appendix E). Well USGS 88 had decreasing concentration trends for carbon tetrachloride, trichloroethene, and 1,1,1-trichloroethane, and no significant trend for trichloromethane (table 8, appendix E). 


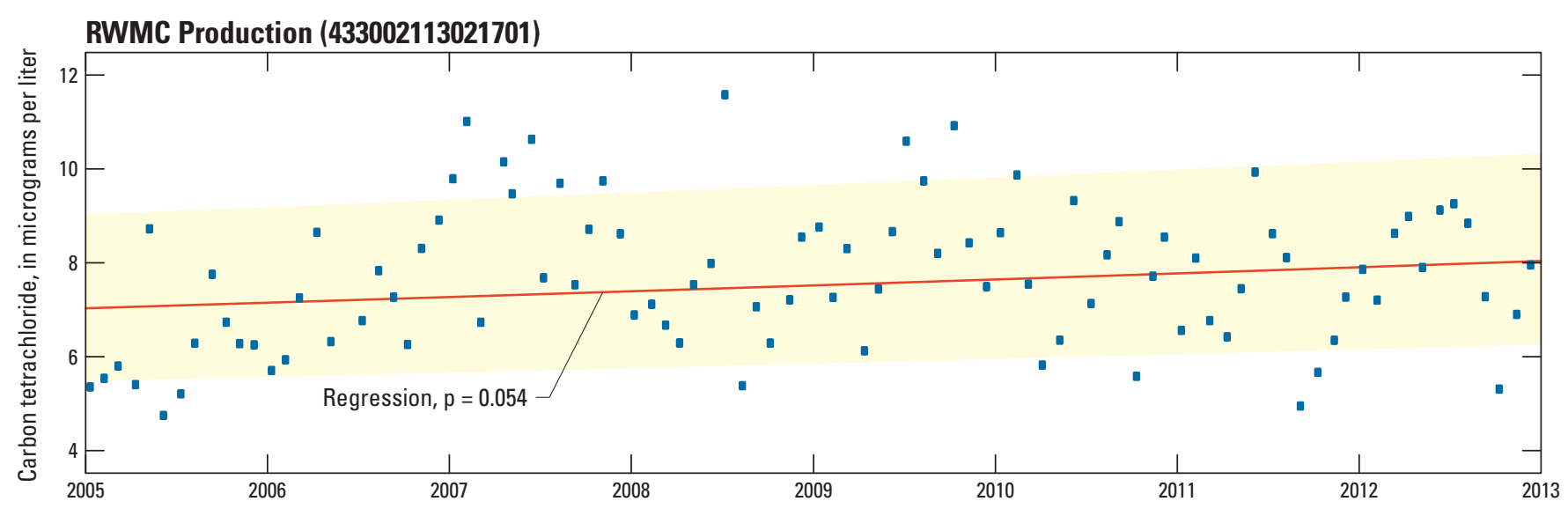

Figure 29. Carbon tetrachloride trend from Radioactive Waste Management Complex Production well, Idaho National Laboratory, Idaho, 2005-12.

Wells near the INTEC and ATR Complex (USGS 34, USGS 38, USGS 65, and USGS 77) had decreasing trends for 1,1,1-trichloroethane. Well USGS 77 also had a decreasing trend for 1,1,-dichloroethene. Wells USGS 34, USGS 38, and USGS 65 had no significant trend for dichlorodifluoromethane, and wells USGS 77 and 84 had decreasing trends for dichlorodifluoromethane. All other VOCs in all of the wells not mentioned had concentrations less than their respective reporting levels.

\section{Factors Influencing Water-Quality Trends at Each Well}

Chloride, chromium, nitrate, sodium, and sulfate are the primary non-radioactive constituents that have been discharged in wastewater at INL facilities. Additionally, elevated concentrations of these constituents in water samples also can come from other anthropogenic sources. Tritium and strontium-90 are the primary radioactive constituents that have been discharged in wastewater at INL facilities. Because of this, these are the primary constituents discussed for each well.

\section{Aquifer Wells near Idaho Nuclear Technology and Engineering Center}

CPP-1.-Trend test results for this well indicate that chloride, nitrate, sulfate, and tritium concentrations show decreasing trends, chromium shows an increasing trend, and fluoride, sodium, and strontium-90 show no trend (tables 5 and 7 ). The decreasing trends are attributed to discontinued disposal of these constituents at the INTEC along with continued dilution and dispersion in the aquifer system, and to radioactive decay for tritium.
CPP-2.-Chloride, nitrate, and sulfate concentrations show decreasing trends and sodium, strontium-90, and tritium show no trend (tables 5 and $\underline{7}$ ). The decreasing trends are attributed to discontinued disposal of these constituents at the INTEC along with continued dilution and dispersion in the aquifer system.

Rifle Range well.- Sodium and chloride concentrations show an increasing trend, and chromium, sulfate, and tritium show a decreasing trend, and strontium-90 shows no trend (tables 5 and $\underline{7}$ ). The increases in sodium and chloride are related to waste disposal into the new INTEC percolation ponds upgradient of this well beginning in 2002. The decreasing trends are attributed to discontinued disposal of these constituents, continued dilution and dispersion in the aquifer system, and to radioactive decay for tritium.

USGS 20.-Chloride, sodium, and nitrate concentrations all show increasing trends, tritium shows a decreasing trend, and sulfate and strontium- 90 show no trend (tables 5 and 7 ). The decreasing trend for tritium can probably be attributed to lack of recent wastewater disposal and to radioactive decay. The increasing trends of the other constituents are probably due to a mass of water from periods of higher wastewater disposal reaching this well and increasing the overall concentration in the aquifer over time.

USGS 34.-Chloride, sodium, 1,1,1,-trichloroethane, tritium, and strontium-90 concentrations all show decreasing trends, sulfate and chromium show increasing trends, and nitrate and fluoride show no trend (tables 5 and 7 ). The decreasing trends for sodium, chloride, 1,1,1,-trichloroethane, tritium, and strontium- 90 probably can be attributed to lack of recent wastewater disposal, and to radioactive decay in the case of tritium and strontium-90. Sulfate and chromium increases could be the result of wastewater discharged at the ATR Complex finally reaching this well and causing concentrations to increase. Several of the constituents 
(especially sulfate) (appendix D) show fluctuating concentrations with rising and declining water levels, so dilution or lack of dilution from recharge also be may contributing to the concentration changes.

USGS 35.-Chloride, nitrate, sodium, and tritium concentrations show decreasing trends, sulfate shows an increasing trend, and strontium- 90 shows no trend (tables 5 and $\underline{7}$ ). The decreasing trends for chloride, nitrate, and sodium and tritium can probably be attributed to lack of recent wastewater disposal and to radioactive decay in the case of tritium. Sulfate increases could be the result of wastewater discharged at the ATR Complex finally reaching this well and causing concentrations to increase. Several of the constituents (especially sulfate) (appendix D, fig. 20) show fluctuating concentrations with rising and declining water levels, so dilution or lack of dilution from recharge may also be contributing to the concentration changes.

USGS 36.-Chloride, nitrate, sodium, tritium, and strontium-90 concentrations all show decreasing trends, and sulfate shows an increasing trend (tables 5 and 7 ). The decreasing trends for sodium, chloride, nitrate, tritium, and strontium-90 probably can be attributed to lack of recent wastewater disposal and to radioactive decay in the case of tritium and strontium-90. Sulfate increases could be the result of wastewater discharged at the ATR Complex finally reaching this well and causing concentrations to increase.

USGS 37.-Chloride, sodium, nitrate, tritium, and strontium-90 concentrations all show decreasing trends, and sulfate shows an increasing trend (tables 5 and 7 ). The decreasing trends for sodium, chloride, tritium, and strontium-90 probably can be attributed to lack of recent wastewater disposal and to radioactive decay in the case of tritium and strontium-90. Sulfate increases could be the result of wastewater discharged at the ATR Complex finally reaching this well and causing concentrations to increase.

USGS 38.-Chloride, nitrate, sodium,

1,1,1,-trichloroethane, tritium, and strontium-90 concentrations all show decreasing trends, and chromium, fluoride, and sulfate show an increasing trend (tables 5, $\underline{7}$, and $\underline{8}$ ). The decreasing trends for sodium, chloride, $1,1,1$, -trichloroethane, tritium, and strontium-90 probably can be attributed to lack of recent wastewater disposal and to radioactive decay in the case of tritium and strontium-90. Chromium and sulfate increases could be the result of wastewater discharged at the ATR Complex finally reaching this well and causing concentrations to increase.

USGS 39.-Tritium concentrations show a decreasing trend, sulfate and sodium show increasing trends, and chloride, nitrate and strontium-90 show no trend (tables 5 and 7, appendixes C and D). This well is near the Big Lost River and concentrations of all the constituents seem to fluctuate opposite to increases and decreases with water levels in the aquifer (fig. 20). For example, all the concentrations were the lowest when the water level was at its highest around 2000.
USGS 40.-Chloride, sulfate, tritium, and strontium-90 concentrations all show decreasing trends, and nitrate and sodium show no trend (tables 5 and 7 ). The decreasing trends for chloride, sulfate, tritium, and strontium-90 probably can be attributed to lack of recent wastewater disposal and to radioactive decay in the case of tritium and strontium-90.

USGS 41.-Chloride, sulfate, tritium, and strontium-90 concentrations all show decreasing trends, and nitrate and sodium show no trend (tables 5 and 7 ). The decreasing trends for chloride, sulfate, tritium, and strontium-90 probably can be attributed to lack of recent wastewater disposal and to radioactive decay in the case of tritium and strontium-90.

USGS 42.-Chloride, sulfate, tritium, and strontium-90 concentrations show decreasing trends, and nitrate and sodium show no trend (tables 5 and $\underline{7}$ ). The decreasing trends probably can be attributed to dilution and dispersion and the lack of recent wastewater disposal near this well and to radioactive decay for tritium and strontium-90.

USGS 43.-Chloride, tritium, and strontium-90 concentrations show decreasing trends, and nitrate, sulfate, and sodium show no trend (tables 5 and 7 ). The decreasing trends probably can be attributed to dilution and dispersion and the lack of recent wastewater disposal near this well and to radioactive decay for tritium and strontium-90.

USGS 44.-Chloride, nitrate, sodium, tritium, and strontium-90 concentrations show decreasing trends and sulfate shows no trend (tables 5 and 7 ). The decreasing trends probably can be attributed to dilution and dispersion and the lack of recent wastewater disposal near this well and to radioactive decay for tritium and strontium- 90 .

USGS 45.-Chloride, sulfate, tritium, and strontium-90 concentrations show decreasing trends, and nitrate and sodium show no trend (tables 5 and $\underline{7}$ ). The decreasing trends probably can be attributed to dilution and dispersion and the lack of recent wastewater disposal near this well and to radioactive decay for tritium and strontium-90.

USGS 46.-Chloride, nitrate, sodium, sulfate, tritium, and strontium-90 concentrations show decreasing trends (tables 5 and 7 ). The decreasing trends probably can be attributed to dilution and dispersion and the lack of recent wastewater disposal near this well and to radioactive decay for tritium and strontium-90.

USGS 47.-Chloride, sodium, sulfate, tritium, and strontium-90 concentrations show decreasing trends, and nitrate shows no trend (tables 5 and 7 ). The decreasing trends probably can be attributed to dilution and dispersion and the lack of recent wastewater disposal near this well and to radioactive decay for tritium and strontium-90.

USGS 48.-Chloride, sulfate, tritium, and strontium-90 concentrations show decreasing trends, and nitrate and sodium show no trend (tables 5 and $\underline{7}$ ). The decreasing trends probably can be attributed to dilution and dispersion and the lack of recent wastewater disposal near this well and to radioactive decay for tritium and strontium-90. 
USGS 51.-Nitrate and tritium concentrations show decreasing trends, chloride, sodium, and sulfate show increasing trends, and strontium-90 shows no trend (tables 5 and 7). The decreasing trends probably can be attributed to dilution and dispersion and the lack of recent wastewater disposal near this well and to radioactive decay for tritium. The increasing trends for the other constituents may be due to remnant movement of these constituents from the old percolation ponds until 2002 when the new percolation ponds were put into service; as appendix D shows, concentrations do start to decrease slightly after 2002.

USGS 52.-Chloride, tritium, and strontium- 90 concentrations show decreasing trends, and nitrate, sulfate, and sodium show no trend (tables 5 and 7 ). The decreasing trends probably can be attributed to dilution and dispersion and the lack of recent wastewater disposal near this well and to radioactive decay for tritium and strontium-90.

USGS 57.-Chloride, nitrate, sodium, sulfate, tritium, and strontium-90 concentrations show decreasing trends (tables 5 and 7). The decreasing trends probably can be attributed to dilution and dispersion and the lack of recent wastewater disposal near this well and to radioactive decay for tritium and strontium-90.

USGS 59.-Chloride, nitrate, sodium, sulfate, tritium, and strontium- 90 concentrations all show decreasing trends (tables 5 and 7). The decreasing trends probably can be attributed to dilution and dispersion and the lack of recent wastewater disposal near this well and to radioactive decay for tritium and strontium-90.

USGS 67.-Chloride, sodium, sulfate, tritium, and strontium-90 concentrations show decreasing trends and nitrate shows an increasing trend (tables 5 and $\underline{7}$ ). The decreasing trends probably can be attributed to dilution and dispersion and the lack of recent wastewater disposal near this well and to radioactive decay for tritium and strontium-90. Nitrate concentrations have fluctuated through the period of record (appendix D) and the increase may indicate another possible source of contamination other than the infiltration ponds.

USGS 77.-Chloride, chromium, sulfate, nitrate, and tritium concentrations show decreasing trends, fluoride shows an increasing trend, and sodium and strontium- 90 show no trend (tables 5 and 7). The decreasing trends probably can be attributed to dilution and dispersion and the lack of recent wastewater disposal near this well and to radioactive decay for tritium.

USGS 82.-Chloride, nitrate, sodium, and tritium concentrations show decreasing trends, and sulfate and strontium-90 show no trend (tables 5 and 7). The decreasing trends probably can be attributed to dilution and dispersion and the lack of recent wastewater disposal near this well and to radioactive decay for tritium.
USGS 84.- - Tritium concentrations show a decreasing trend, and chloride, nitrate, sodium, sulfate, and strontium-90 show no trend. This well is near the Big Lost River, and concentrations of all the constituents seem to fluctuate opposite to increases and decreases of water levels in the aquifer (appendixes $\mathrm{C}$ and $\underline{\mathrm{D}}$ ). For example, all concentrations (except for the trace elements) were the lowest when the water level was at its highest about 1998-2000. The large decrease in zinc in the mid-2000s (appendix D) is probably due to the change of a galvanized sample pipe to stainless steel.

USGS 85.- Tritium, chloride, nitrate, and sodium concentrations show decreasing trends, and sulfate shows an increasing trend and strontium-90 shows no trend (tables 5 and 7 ). The decreasing trends are attributed to discontinued wastewater disposal at the INTEC and to radioactive decay for tritium. The increasing trend for sulfate could be due to water from the ATR Complex finally reaching this well.

USGS 111.-Nitrate, sodium, sulfate, and tritium concentrations show decreasing trends, and chloride and strontium-90 show no trend (tables 5 and 7 ). The decreasing trends probably can be attributed to dilution and dispersion and the lack of recent wastewater disposal near this well and to radioactive decay for tritium.

USGS 112.-Chloride, nitrate, sodium, sulfate, tritium, and strontium-90 concentrations all show decreasing trends (tables 5 and 7 ). The decreasing trends probably can be attributed to dilution and dispersion and the lack of recent wastewater disposal near this well and to radioactive decay for tritium and strontium-90.

USGS 113.-Chloride, sulfate, sodium, tritium, and strontium-90 concentrations show decreasing trends and nitrate shows no trend (tables 5 and $\underline{7}$ ). The decreasing trends probably can be attributed to dilution and dispersion and the lack of recent wastewater disposal near this well and to radioactive decay for tritium.

USGS 114.- Nitrate and tritium concentrations show decreasing trends, chloride shows an increasing trend, and sodium, sulfate, and strontium- 90 show no trend (tables 5 and 7 ). The decreasing trends for nitrate and tritium probably can be attributed to lack of recent wastewater disposal near this well and to radioactive decay for tritium. The increase in chloride is probably due to the variable wastewater disposal in the past and slower groundwater movement to this well than to other wells in this area.

USGS 115.-Tritium concentrations show a decreasing trend, chloride and sulfate show increasing trends, and nitrate, sodium, and strontium-90 show no trend (tables 5 and 7 ). The decreasing trends for tritium probably can be attributed to lack of recent wastewater disposal near this well and to radioactive decay. The increase in chloride and sulfate is probably due to variable wastewater disposal in the past and slower groundwater movement to this well than to other wells in this area. 
USGS 116.- -Nitrate, sulfate, and tritium concentrations show decreasing trends, chloride shows an increasing trend, and sodium and strontium-90 show no trend (tables 5 and 7 ). The decreasing trends probably can be attributed to lack of recent wastewater disposal near this well and to radioactive decay for tritium. The increase in chloride is probably due to the more variable wastewater disposal of this constituent compared to the others in the past and slower groundwater movement to this well than to other wells in this area.

USGS 123.-Chloride, nitrate, sulfate, sodium, tritium, and strontium-90 concentrations all show decreasing trends (tables 5 and 7). The decreasing trends probably can be attributed to dilution and dispersion and the lack of recent wastewater disposal near this well, deepening of the well, and to radioactive decay for tritium and strontium-90. The large drop in concentrations in 2005 (appendix $C$ and $\underline{D}$ ) are due the deepening of this well in 2004 (Forbes and others, 2007), which resulted in sampling a larger zone of the upper part of the aquifer, thereby diluting future samples.

USGS 128. - Chloride, nitrate, and tritium concentrations show decreasing trends, and strontium-90 shows no trend (tables 5 and 7). The decreasing trends probably can be attributed to dilution and dispersion and the lack of recent wastewater disposal near this well and to radioactive decay for tritium.

\section{Aquifer Wells near Advanced Test Reactor Complex}

MTR TEST. - Chloride, nitrate, sodium, sulfate, and tritium concentrations all show decreasing trends (tables 5 and 7). The decreasing trends are attributed to discontinued disposal of these constituents at the ATR Complex, along with clean-up of ponds the constituents were disposed of in the past. Although concentrations of tritium and sodium generally are decreasing, they show increases from 1990 to 1994 before decreasing (appendixes $\mathrm{C}$ and $\underline{\mathrm{D}}$ ); the increases were probably due to disposal in the radioactive-waste ponds reaching the aquifer before the ponds were taken out of service in the case of tritium and due to variable disposal in the chemical waste pond in the case of sodium.

TRA Disposal.-CTritium, nitrate, sodium, and sulfate concentrations show decreasing trends and chloride and strontium-90 show no trend (tables 5 and 7). The decreasing trends are attributed to discontinued disposal of these constituents at the ATR Complex along with continued dilution and dispersion in the aquifer system, and because of radioactive decay for tritium.

USGS 58.-Tritium concentrations show a decreasing trend, sodium and sulfate show increasing trends, and chloride, chromium, and strontium- 90 show no trend (tables 5 and 7). The decreasing trends for tritium probably can be attributed to lack of recent wastewater disposal near this well and to radioactive decay. The increasing sodium and sulfate concentrations are probably due to wastewater disposal in the chemical and cold waste ponds at the ATR Complex.

USGS 65.-Chromium and tritium concentrations show decreasing trends, sodium and sulfate show increasing trends, and chloride, nitrate, and strontium- 90 show no trend (tables 5 and 7). The decreasing trends for chromium and tritium probably can be attributed to lack of recent wastewater disposal and to radioactive decay in the case of tritium. The increasing sodium and sulfate concentrations are probably due to wastewater disposal in the chemical and cold waste ponds at the ATR Complex. The large decrease in zinc in the mid-2000s (table 7) is probably due to the change of a galvanized sample pipe to stainless steel.

USGS 76.-Tritium concentrations show a decreasing trend, sodium and sulfate show increasing trends, and chloride, chromium, nitrate, and strontium- 90 show no trend (tables 5 and 7). The decreasing trend for tritium probably can be attributed to lack of recent wastewater disposal near this well and to radioactive decay. The increasing sodium and sulfate concentrations are probably due to wastewater disposal in the chemical and cold waste ponds at the ATR Complex.

USGS 79.-Chloride concentrations show a decreasing trend, and sodium, sulfate, and tritium show no trend (tables 5 and 7). The decreasing trend for chloride probably can be attributed to Big Lost River seepage in this part of the aquifer diluting the amount of chloride.

\section{Aquifer Wells near Central Facilities Area}

CFA-1.-Tritium, nitrate, and sulfate concentrations show decreasing trends and chloride, sodium, and strontium-90 show no trend (tables 5 and 7 ). The decreasing trends are attributed to discontinued disposal of these constituents at the INTEC along with continued dilution and dispersion in the aquifer system and also because of radioactive decay for tritium.

CFA-2.-Chloride, sodium, sulfate, and nitrate concentrations all show increasing trends, tritium shows a decreasing trend, and strontium-90 shows no trend (tables 5 and $\underline{7}$ ). The decreasing trend for tritium probably can be attributed to lack of recent wastewater disposal and to radioactive decay. The increasing trends of the other constituents are probably due to a mass of water from periods of high wastewater disposal reaching this well and increasing the overall concentration in the aquifer over time. Busenberg and others (2001) indicated that this well contains about three-quarters young water, whereas CFA 1 consists of only about half young water, so this well may be more influenced by past wastewater disposal. This well is in the southern part of the CFA, and the increasing nitrate trend could be attributed to leakage from disposal at the former CFA mercury pond (U.S. Department Energy, 2011). 
CFA LF 2-10.- Tritium, nitrate, and chromium concentrations show decreasing trends, sodium shows an increasing trend, and chloride and strontium-90 show no trend (tables 5 and 7 ). The decreasing trends are attributed to discontinued disposal of these constituents at the INTEC along with continued dilution and dispersion in the aquifer system and because of radioactive decay for tritium. The increasing sodium trend may be due to a mass of water from a previous higher disposal period reaching this well and increasing the overall concentration in the aquifer; this trend may be an indication that sodium is moving more slowly in the aquifer than some of the other constituents.

CFA LF 3-9.-Nitrate concentrations show a decreasing trend, chloride shows an increasing trend, and tritium and strontium-90 show no trend (tables 5 and $\underline{7}$ ). The decreasing trend for nitrate is attributed to discontinued disposal at the INTEC along with continued dilution and dispersion in the aquifer system. The increasing trend for chloride is attributed to variable chloride disposal finally reaching this well and three of the four values collected since 2002 decreased from previous samples (appendix D).

USGS 127.- Sodium concentrations show an increasing trend, chromium shows a decreasing trend, and chloride, nitrate, tritium, and strontium-90 show no trend (tables 5 and 7). The increasing trend of sodium probably is due to a mass of water from periods of higher wastewater disposal reaching this well and increasing the overall concentration in the aquifer over time. Although regional flow paths indicate that wastewater should move through this area, the water chemistry in this well is indicative of natural aquifer background, except for chromium.

\section{Aquifer Wells near Radioactive Waste Management Complex}

RWMC M3S.-Chloride concentrations show an increasing trend and nitrate, tritium, and strontium- 90 show no trend (tables 5 and 7 ). The increasing chloride trend may be due to a mass of water from periods of higher wastewater disposal reaching this well and increasing the overall concentration in the aquifer over time, or may be due to slow seepage from buried waste at RWMC.

RWMC M7S.-Chloride and nitrate concentrations show an increasing trend and tritium and strontium- 90 show no trend (tables 5 and 7). The increasing chloride and nitrate trends may be due to a mass of water from periods of higher wastewater disposal reaching this well and increasing the overall concentrations in the aquifer over time, or may be due to slow seepage from buried waste at RWMC.

RWMC M11S. - Trend test results for constituents in water from this well indicate no trends for any of the major constituents for which trend analyses were completed (tables 5 and 7 ).
RWMC M12S. - Chloride and nitrate concentrations show increasing trends, chromium has a decreasing trend, and tritium and sodium show no trend (tables 5 and $\underline{7}$ ). The increasing chloride and nitrate trends may be due to a mass of water from periods of higher wastewater disposal reaching this well and increasing the overall concentrations in the aquifer over time.

RWMC M13S.- Trend test results for constituents in water from this well indicate no trends for any of the major constituents for which trend analyses were completed (tables 5 and 7). Although regional flow paths indicate that wastewater from the INTEC/ATR Complex disposal should move through this area, the water chemistry in this well seems to be indicative of natural aquifer background concentrations except for chromium.

RWMC M14S. - Chromium and tritium concentrations show decreasing trends and no trend for chloride, nitrate, and sodium (tables 5 and 7 ). The decreasing concentrations are probably due to dilution and dispersion in the aquifer and also due to radioactive decay for tritium.

RWMC Production.-Chloride and sodium concentrations along with the VOCs 1,1,1-trichloroethane, tetrachloroethene, carbon tetrachloride, trichloroethene, trichloromethane, and tribromomethane (tables 7 and $\underline{8}$, appendixes $\mathrm{D}$ and $\mathrm{E}$ ) show increasing trends. Nitrate, sulfate, tritium, and strontium-90 show no trend. The increasing constituent trends are likely due to the movement of wastes buried at the RWMC moving to the aquifer.

USGS 87.-Chromium and nitrate concentrations show a decreasing trend; chloride, sodium, trichloromethane, trichloroethene, carbon tetrachloride, dichlorodifluoromethane, and tritium show increasing trends; and sulfate and strontium-90 show no trend (tables 5 , $\underline{7}$, and $\underline{8}$ ). Both sodium and chloride show large increases in 2005 (appendix D). This well is along the flow path downgradient of the new INTEC percolation ponds installed in 2002 , so the changes in these concentrations are attributed to disposal in the new ponds. The increases in the VOCs are attributed to continued leakage from buried waste at RWMC.

USGS 88.-Concentrations of 1,1,1-trichloroethane, carbon tetrachloride, nitrate, sodium, sulfate, and trichloroethene show decreasing trends, and chloride, tritium, and strontium-90 show no trend (tables 5,7 , and $\underline{8}$ ). The decreasing concentrations of the constituents may be an indication that clean-up at RWMC is having a positive influence on the aquifer where this well is located.

USGS 89.- Nitrate concentrations show a decreasing trend, and chloride, sodium, sulfate, tritium, and strontium- 90 show no trend (tables 5 and 7 ). The decreasing concentrations of nitrate may be an indication that clean-up at RWMC is having a positive influence on the aquifer where this well is located. 
USGS 120.-Chloride, sodium, sulfate, and tetrachloroethene concentrations show decreasing trends, carbon tetrachloride and trichloromethane show an increasing trend, and nitrate, tritium, and strontium-90 show no trend (tables 5, $\underline{7}$, and $\underline{8}$ ). Sodium, sulfate, and several VOCs show large increases in the late 1990s and early 2000s and, conversely, nitrate shows a decrease in the same period (appendixes $\mathrm{C}$ and $\mathrm{E}$ ). This well is near the INL spreading areas (fig. 1) and was influenced by spreading area water from 1996 to 1999 (Bartholomay and others, 2000; Nimmo and others, 2002). The nitrate decrease corresponds with an increase of dilution from spreading area water, but the other constituent increases do not. The increase of the VOCs may suggest a large movement of contaminants from the unsaturated zone below the RWMC during this period and spreading area recharge may have been a factor that influenced the increase in the movement of the buried waste.

\section{Aquifer Wells South of Facilities}

USGS 104. - Chloride, sodium, and nitrate concentrations show increasing trends, and tritium shows no trend (tables 5 and $\underline{7}$ ). The increasing trends may represent the overall increase due to a mass of water from higher wastewater disposal periods reaching this well and increasing the overall concentration in the aquifer over time.

USGS 105.-Sodium and chloride concentrations show decreasing trends, nitrate shows an increasing trend, and tritium shows no trend (tables 5 and 7 ). The decreasing sodium and chloride may be an indicator that the sodium and chloride concentrations are originating from a different source than INTEC disposal and may have different travel times than other wells near the southern border. The presence of chromium concentrations above background concentrations may suggest some water originates from the ATR Complex area.

USGS 106.-Tritium concentrations show a decreasing trend, sodium shows an increasing trend, and chloride shows no trend (tables 5 and 7 ). The increasing trend for sodium may be due to a mass of water from periods of higher wastewater disposal reaching this well and increasing the overall concentration in the aquifer over time. The decreasing tritium concentration is probably due to radioactive decay.

USGS 108.-Chloride, nitrate, sodium, and tritium concentrations show no trend (tables 5 and 7 ). Concentrations of the inorganic constituents generally are at levels considered as background for the ESRP and water from this well probably represents well-mixed aquifer water with little influence from wastewater disposal.

USGS 124. -Chloride and nitrate concentrations show increasing trends, and sodium and tritium show no trend (tables 5 and 7). The increasing trends may be due to a mass of water from periods of higher wastewater disposal reaching this well and increasing the overall concentration in the aquifer over time.

\section{Perched Groundwater Wells near Idaho Nuclear Technology and Engineering Center}

PW 1.-Chloride, tritium, and strontium-90 concentrations show decreasing trends and sodium shows no trend (tables 5 and $\underline{7}$ ). This well gets all of its water from leakage from the old percolation ponds at the INTEC that were taken out of service in 2002 and the trends are attributed to variable wastewater disposal.

PW 2.-Chloride, sodium, and tritium concentrations show decreasing trends, and sulfate and strontium-90 show no trend (tables 5 and $\underline{7}$ ). This well gets all of its water from leakage from the old percolation ponds at the INTEC that were taken out of service in 2002 and the trends are attributed to variable wastewater disposal.

PW 3.-Chloride, tritium, and strontium- 90 concentrations show a decreasing trend and sodium shows no trend (tables 5 and $\underline{7}$ ). This well gets all of its water from leakage from the old percolation ponds at the INTEC that were taken out of service in 2002 and the trends are attributed to variable wastewater disposal.

PW 4. - Chloride, sodium, strontium-90 and tritium concentrations show decreasing trends, and sulfate shows an increasing trend (tables 5 and $\underline{7}$ ). This well gets most of its water from leakage from the old percolation ponds at the INTEC that were taken out of service in 2002 and the trends are attributed to variable wastewater disposal.

PW 5.-Tritium and strontium- 90 concentrations show decreasing trends, and chloride and sodium show no trend (tables 5 and 7). This well gets all of its water from leakage from the old percolation ponds at the INTEC that were taken out of service in 2002 and the trends are attributed to variable wastewater disposal.

PW 6. - Tritium concentrations show a decreasing trend and chloride and strontium-90 show no trend (tables 5 and 7). This well gets all of its water from leakage from the old percolation ponds at the INTEC that were taken out of service in 2002 and the trends are attributed to variable wastewater disposal.

USGS 50.-Chloride, nitrate, tritium, and strontium- 90 concentrations show decreasing trends, and sodium and sulfate show no trend (tables 5 and $\underline{7}$ ). This well gets most of its water from leakage from cracks in the old INTEC disposal well and leaky pipes around INTEC and the trends can be attributed to variable wastewater disposal and radioactive decay. The well was abandoned in 2009.

\section{Perched Groundwater Wells near Advanced Test Reactor Complex}

CWP 1.- Sulfate concentrations show a decreasing trend and chloride, chromium, tritium, and strontium-90 show no trend (tables 5 and 7 ). This well gets most of its water from 
leakage from the cold waste ponds at the ATR Complex and the trend and lack of trends is due to variable discharge of the constituents in the wastewater.

CWP 2.-Chloride concentrations show no trend (table 7). This well gets most of its water from leakage from the cold waste ponds at the ATR Complex and the lack of trend is due to variable discharge in the wastewater.

CWP 3.-Chromium concentrations show a decreasing trend and chloride, sulfate, tritium, and strontium-90 show no trend (tables 5 and 7). This well gets most of its water from leakage from the cold waste ponds at the ATR Complex and the trends are due to variable discharge of the constituents in the wastewater.

CWP 4.-Chloride concentrations show a decreasing trend and tritium and strontium-90 show no trend (tables 5 and 7). This well gets most of its water from leakage from the cold waste ponds at the ATR Complex and the decreasing trend is attributed to variable wastewater disposal.

CWP 5.- Tritium concentrations show no trend (table 5).

CWP 8.-Chloride and sulfate concentrations show decreasing trends and chromium, tritium, and strontium-90 show no trend (tables 5 and 7). This well gets most of its water from leakage from the cold waste ponds at the ATR Complex and the trends are attributed to variable wastewater disposal.

PW 8.-Chromium, sulfate, tritium, and strontium-90 concentrations show decreasing trends, and chloride and sodium show no trend (tables 5 and $\underline{7}$ ). This well gets most of its water from leakage from the old radioactive-waste infiltration ponds that were discontinued in 1993 and from leakage from the cold waste ponds near the ATR Complex. The trends are attributed to variable wastewater disposal and to radioactive decay for tritium and strontium- 90 .

PW 9.-Chromium, sodium, sulfate, and tritium concentrations show decreasing trends, chloride shows an increasing trend, and strontium-90 shows no trend (tables 5 and 7). This well gets most of its water from leakage from the old radioactive-waste infiltration ponds that were discontinued in 1993 and from leakage from the cold waste ponds near the ATR Complex. The trends are attributed to variable wastewater disposal and to radioactive decay for tritium.

TRA A 13.- Tritium and strontium- 90 concentrations show decreasing trends, and chloride shows an increasing trend (tables 5 and 7 ). This well gets most of its water from leakage from the old radioactive-waste infiltration ponds that were discontinued in 1993. The trends can be attributed to variable discharge and radioactive decay. Sampling was discontinued in 2008 and the well was later abandoned.

TRA A 77.-Tritium concentrations show a decreasing trend, chloride and strontium-90 show increasing trends (table 5 and 7). This well gets most of its water from leakage from a retention basin prior to flow to the old radioactive-waste infiltration ponds that were discontinued in 1993. The trends can be attributed to variable wastewater disposal and radioactive decay and a different affinity for strontium-90 to absorb to sediments and then possibly get reintroduced later to the water column through cation exchange. Sampling was discontinued in 2008 and the well was later abandoned.

USGS 53.-Tritium and strontium-90 concentrations show decreasing trends, and chloride, chromium, and sodium show no trend (tables 5 and $\underline{7}$ ). This well previously was used as a disposal well and gets most of its water from leakage from the old radioactive-waste infiltration ponds that were discontinued in 1993 and from leakage from the cold waste ponds near the ATR Complex. The trends (or lack of trends) are attributed to variable wastewater disposal, discontinuation of disposal to the radioactive waste ponds, and radioactive decay for tritium and strontium-90.

USGS 54.-Chromium, sulfate, tritium, and strontium-90 concentrations show decreasing trends, and chloride and sodium show no trend (tables 5 and 7 ). This well historically got most of its water from leakage from the old radioactivewaste infiltration ponds that were discontinued in 1993 and from leakage from the cold waste ponds near the ATR Complex. The trends (or lack of trends) are attributed to variable wastewater disposal, discontinuation of disposal to the radioactive waste ponds, and radioactive decay for tritium and strontium-90.

USGS 55.-Chloride and chromium concentrations show decreasing trends, strontium-90 shows an increasing trend, and sodium, sulfate, and tritium show no trend (tables 5 and 7). This well historically got most of its water from leakage from the old radioactive-waste infiltration ponds that were discontinued in 1993 and from leakage from the cold waste ponds near the ATR Complex. The trends (or lack of trends) are attributed to variable wastewater disposal. Strontium-90 shows an increasing trend through 2006 and then concentrations decrease (appendix C). The increase could be due to sodium discharge into the chemical waste pond exchanging with strontium-90 making it mobile; the subsequent decrease after 2006 could be due to the closing of the chemical waste ponds in 1999. Although sodium does not show a statistically significant trend, sodium concentrations in this well do somewhat show an inverse relationship with strontium-90 concentrations (appendixes $\mathrm{C}$ and $\underline{\mathrm{D}}$ ).

USGS 56.-Tritium concentrations show a decreasing trend, and chloride, chromium, sodium, and strontium-90 show no trend (tables 5 and 7). This well gets most of its water from leakage from the old radioactive-waste infiltration ponds that were discontinued in 1993 and from leakage from the cold waste ponds near the ATR Complex. The trends (or lack of trends) are attributed to variable wastewater disposal, discontinuation of disposal to the radioactive waste ponds, and radioactive decay for tritium.

USGS 60.-Chromium, sulfate, and tritium concentrations show decreasing trends, and chloride, sodium, and strontium-90 show no trend (tables 5 and 7 ). This well gets most of its water from leakage from the old 
radioactive-waste infiltration ponds that were discontinued in 1993 and from leakage from the cold waste ponds near the ATR Complex. The trends (or lack of trends) are attributed to variable wastewater disposal.

USGS 61.-Chromium, sodium, and tritium concentrations show decreasing trends, and chloride, sulfate, and strontium-90 show no trend (tables 5 and 7 ). This well gets most of its water from leakage from the old radioactivewaste infiltration ponds that were discontinued in 1993 and from leakage from the cold waste ponds near the ATR Complex and the trends (or lack of trends) are attributed to variable wastewater disposal and to radioactive decay for tritium.

USGS 62.-Chromium and tritium concentrations show decreasing trends, and chloride, chromium, sulfate, and strontium-90 show no trend (tables 5 and 7 ). This well gets most of its water from leakage from the old radioactive-waste infiltration ponds that were discontinued in 1993 and from leakage from the cold waste ponds near the ATR Complex. The trends (or lack of trends) are attributed to variable wastewater disposal and to radioactive decay for tritium.

USGS 63.-Chromium, sulfate, tritium, and strontium-90 concentrations show a decreasing trend, and chloride and sodium show no trend (tables 5 and $\underline{7}$ ). This well gets most of its water from leakage from the old radioactive-waste infiltration ponds that were discontinued in 1993 and from leakage from the cold waste ponds near the ATR Complex. The trends (or lack of trends) are attributed to variable wastewater disposal and to radioactive decay for tritium and strontium-90.

USGS 66.- - Tritium concentrations show a decreasing trend, and chromium, sodium, sulfate, and strontium-90 show no trend (tables 5 and 7 ). This well gets most of its water from leakage from the old radioactive-waste infiltration ponds that were discontinued in 1993 and from leakage from the cold waste ponds near the ATR Complex. The trends (or lack of trends) are attributed to variable wastewater disposal and to radioactive decay for tritium.

USGS 68.-Chloride, sodium, and sulfate concentrations show decreasing trends, chromium shows an increasing trend, and tritium and strontium- 90 show no trend (tables 5 and $\underline{7}$ ). This well gets most of its water from leakage from the chemical waste infiltration ponds that were discontinued in 1999 and the cold waste-ponds at the ATR Complex. The trends are attributed to variable wastewater disposal.

USGS 69.-Chloride and sulfate concentrations show decreasing trends, and chromium, sodium, tritium, and strontium-90 show no trend (tables 5 and 7 ). This well gets most of its water from leakage from the old radioactive-waste infiltration ponds that were discontinued in 1993 and from leakage from the cold waste ponds near the ATR Complex. The trends (or lack of trends) are attributed to variable wastewater disposal.
USGS 70.-Chloride, chromium, tritium, and strontium-90 concentrations show decreasing trends, and sulfate and sodium show no trend (tables 5 and 7 ). This well historically got most of its water from leakage from the old radioactive waste infiltration ponds that were discontinued in 1993 and from leakage from the cold waste ponds near the ATR Complex. The trends (or lack of trends) are attributed to variable wastewater disposal, discontinuation of disposal to the radioactive waste infiltration ponds, and to radioactive decay for tritium and strontium-90.

USGS 71.-Chromium and tritium concentrations show decreasing trends; sodium shows an increasing trend; and chloride, sulfate, and strontium- 90 show no trend (tables 5 and 7). This well gets most of its water from leakage from the old radioactive-waste infiltration ponds that were discontinued in 1993 and from leakage from the cold waste ponds near the ATR Complex and the trends (or lack of trends) are attributed to variable wastewater disposal and to radioactive decay for tritium.

USGS 72.-Sulfate concentrations show a decreasing trend, and chloride, chromium, sodium, tritium, and strontium-90 show no trend (tables 5 and 7). This well probably gets most of its water from leakage from landscape irrigation water and from other unknown sources around the ATR Complex and possibly some minimal influence by wastewater ponds around the ATR Complex. The decreasing sulfate may be an indication that the water was influenced by the chemical waste pond and the decreases are probably due to the discontinued use of the pond in 1999.

USGS 73.-Chromium and tritium concentrations show decreasing trends, chloride shows an increasing trend, and sodium, sulfate, and strontium-90 show no trend (tables 5 and 7). This well gets most of its water from leakage from the old radioactive-waste infiltration ponds that were discontinued in 1993 and from leakage from the cold waste ponds near the ATR Complex. The trends are attributed to variable wastewater disposal and to radioactive decay for tritium.

USGS 78.-Chromium concentrations show a decreasing trend, and chloride, sulfate, sodium, tritium and strontium- 90 show no trend (tables 5 and 7). This well probably gets all of its water from recharge from the Big Lost River (Orr, 1999), and the increasing chromium may be due to variable reporting levels as only four concentrations exceeded the reporting level (appendix D).

\section{Perched Groundwater Well at Radioactive Waste Management Complex}

USGS 92.-Chloride, tritium, and strontium-90 concentrations show no trend (tables 5 and 7). 


\section{Summary and Conclusions}

The U.S. Geological Survey (USGS), in cooperation with the U.S. Department of Energy, has maintained a water-quality monitoring network at the Idaho National Laboratory (INL) since 1949 to define the quality of water for human and industrial use and to better understand the location and movement of contaminants in the eastern Snake River Plain aquifer underlying the INL. Trends in constituent concentrations for 64 regional aquifer wells and 35 perched groundwater wells were analyzed from 1981 through 2012. Constituents analyzed included some combination of tritium, strontium-90, cesium-137, plutonium-238, plutonium-239, -240 (undivided), americium-241, gross alpha- and betaparticle radioactivity, calcium, magnesium, potassium, silica, sodium, bromide, chloride, fluoride, sulfate, nitrate (as N), orthophosphate (as P), chromium and other trace elements, and total organic carbon. The wells selected for analysis in this report likely were affected by wastewater disposal practices at the INL. Concentration trends were determined to assist with future management decisions concerning which wells to sample and which constituent types to monitor.

Water-quality trends were determined from groundwater data collected after the date of pump installations to eliminate variability associated with sample-collection methods. Concentration trends also were from data sets from the same laboratory, either the USGS National Water Quality Laboratory or the Department of Energy Radiological and Environmental Sciences Laboratory. Data not used for the trend analyses included data from special INL studies, data collected prior to 1981 when laboratory methods were unknown and quality assurance data were not routinely collected, and data collected from different depths in the aquifer using a thief sampler. Outlier data that did not correlate with field-specific conductance measurements and replicate values were not used.

The data were processed using custom computer scripts developed in the $\mathrm{R}$ programming language. All $\mathrm{R}$ functions written for this report are stored in an R-package called "Trends." In addition to the base packages included with $\mathrm{R}$, Trends depends on the "Survival" package. The Trends package identifies statistical trends in water-quality data for multiple constituents and sample sites using a parametric survival regression model for left-censored data (values reported as less than a laboratory reporting level [LRL]), interval-censored data (data with an associated uncertainty), and uncensored data. This "Trends" package also calculates summary statistics of mean, median, minimum, maximum, and standard deviation for multiple constituents, and automates plotting the data and regression lines.

A significance level of 0.05 was selected to determine if the result of the test was statistically significant. A two-sided $p$-value that was less than or equal to 0.05 indicated that there was a statistically significant correlation, or trend, in the data.
The sign of the percent change per year indicated whether there was an increasing or decreasing trend if a significant correlation existed. If $p$-values were greater than 0.05 , there was no statistically significant correlation, or trend, between time and concentration.

Data for field measurements of $\mathrm{pH}$, specific conductance, and water temperature were analyzed for trends. Of the 64 aquifer wells measured for $\mathrm{pH}, 43$ of the wells had a decreasing $\mathrm{pH}$ trend, and 20 wells had no trend. Only one well showed an increasing trend in $\mathrm{pH}$. Of the 35 perched groundwater wells measured, 12 had a decreasing $\mathrm{pH}$ trend, $3 \mathrm{had}$ an increasing $\mathrm{pH}$ trend, and 20 had no trend. It was difficult to assess whether or not the trends for $\mathrm{pH}$ were due to actual changes in the aquifer or perched groundwater, or because of variability in the sample collection methods or meter types.

Sixty-four aquifer wells were analyzed for a trend in specific conductance; 34 had a decreasing trend, 16 had no trend, and 14 had an increasing trend. Most of the wells that showed decreasing or no trend are located near the Idaho Nuclear Technology and Engineering Center (INTEC), and the decreasing trends may be a response to decreased wastewater disposal since 1989 or discontinued use of the old percolation ponds south of the INTEC in 2002. Most aquifer wells that showed an increasing trend are located south and southeast of the INTEC, or north of the RWMC. Most of the specific conductance data in perched groundwater wells near the INTEC and the Advanced Test Reactor Complex (ATR Complex) showed either a decreasing trend or no trend.

Sixty-four aquifer wells were evaluated for temperature trends; 32 showed a decreasing trend, 29 showed no trend, and 3 showed an increasing trend. Of the 35 perched groundwater wells analyzed for temperature trends, 13 showed a decreasing trend, 17 showed no trend, and 5 showed an increasing trend. All the perched groundwater wells with an increasing trend in temperature are near the ATR Complex.

Of the 63 aquifer wells that were analyzed for tritium concentration trends, 45 showed decreasing trends, 1 showed an increasing trend, and 18 showed no trends. Of the 33 perched groundwater wells that were analyzed for tritium trends, 22 showed a decreasing trend and 11 showed no trend. The decreasing trends can be attributed to decreased disposal at facilities and to the radioactive decay of tritium.

Fifty-two aquifer wells were analyzed for strontium-90 concentration trends; 20 showed a decreasing strontium-90 trend and 32 showed no trend. Of the 32 perched groundwater wells that were analyzed for strontium-90 trends, 11 showed a decreasing trend, 19 showed no trend, and 2 showed an increasing trend. The two wells that showed an increasing trend (TRA A 77 and USGS 55) are near the radioactivewaste infiltration ponds at the ATR Complex, and could be influenced by strontium-90 that was discharged to the radioactive-waste infiltration ponds before they were replaced by lined evaporation ponds in 1993. 
Water from 63 wells was analyzed for chloride concentration trends. Thirty-one of these wells had decreasing trends, 17 had no trend, and 15 had an increasing trend. Most wells near the INTEC and ATR Complex showed decreasing or no trends for chloride, probably the result of decreased disposal of wastewater and (or) discontinued use of the old percolation ponds south of the INTEC and redirection of discharge to the new percolation ponds 2 miles southwest of the INTEC in 2002. Chloride concentrations in some wells south of the INTEC were influenced by episodic recharge from the Big Lost River; chloride concentrations decreased during wetter periods when there is probably more recharge from the Big Lost River, and increased during dry periods, when there is less recharge.

Perched groundwater analyzed for chloride concentration trends showed that 10 perched groundwater wells had decreasing trends, 18 had no trend, and 4 had increasing chloride concentration trends.

Sodium hydrate was a predominant constituent in wastewater discharged to the chemical-waste infiltration pond at the ATR Complex, and sodium and chloride were predominant chemical constituents in wastewater discharged at the INTEC and the Central Facilities Area (CFA). Of the 59 aquifer wells analyzed for sodium concentration trends, 22 wells showed a decreasing trend, 23 showed no trend, and 14 showed an increasing trend. The increasing trend for sodium in some wells could be due to the long term influence of wastewater disposal from upgradient facilities and the lack of trend for chloride could be because it is more mobile than sodium and more dispersed in the aquifer system. Five perched groundwater wells analyzed for sodium trends had decreasing trends, 18 had no trend, and 1 well had an increasing trend.

Forty-eight aquifer wells were analyzed for sulfate concentration trends; 24 had decreasing trends, 11 had no trend, and 13 had increasing trends. Most aquifer wells that had increasing trends were located downgradient of the INTEC or ATR Complex, in the general direction of regional groundwater flow to the southwest. Closer to the facilities, sulfate trends either decreased or there was no trend. Most perched groundwater wells near the INTEC and ATR Complex showed decreasing or no trends.

Fifty-nine aquifer wells were analyzed for trends in nitrate concentrations; 28 showed a decreasing trend, 23 showed no trend, and 8 showed an increasing trend. As was shown for chloride, sodium, and sulfate for wells near the Big Lost River, the nitrate concentrations fluctuated in response to recharge from the Big Lost River. Only one well completed in perched groundwater at the INTEC was analyzed for a nitrate trend; it had a decreasing trend.

Trace element concentrations from two wells were analyzed for trends. Well USGS 65 showed no trend for aluminum, antimony, copper, manganese, nickel, and selenium. Barium, cadmium, cobalt, lead, and zinc had decreasing trends, and arsenic, molybdenum, and uranium had increasing trends. Well USGS 84 showed no trend for aluminum, antimony, barium, manganese, molybdenum, selenium and uranium. Cadmium, cobalt, copper, lead, nickel, and zinc showed decreasing trends, and arsenic showed an increasing trend.

Twenty-five aquifer wells were analyzed for chromium concentration trends; 14 showed no trend, 8 showed decreasing trends, and 3 showed increasing trends. The three wells that showed increasing trends are located at or just downgradient of the INTEC. One well downgradient of the ATR Complex showed a decreasing trend. Most of the other wells showing decreasing trends are located near the CFA and the Radioactive Waste Management Complex (RWMC). Of the 21 perched groundwater wells analyzed for chromium trends, 7 showed no trend, 13 showed a decreasing trend, and 1 showed an increasing trend. All the perched groundwater wells that had decreasing trends are south or southeast of the ATR Complex and the decreasing trends are probably due to discontinued disposal.

Volatile organic compound (VOC) concentration trends were analyzed for nine aquifer wells for this study. Historically, concentrations of VOCs in water samples from several wells at and near the RWMC exceeded the reporting levels. Concentrations for all VOCs except carbon tetrachloride were less than the maximum contaminant level (MCL) for drinking water. A plot of carbon tetrachloride concentrations in water from the RWMC Production Well indicates that concentration trends in this well have increased since 1987; however, trend analyses of data collected since 2005 show no statistically significant trend indicating that engineering practices designed to reduce movement of volatile organic compounds to the aquifer may be having a positive effect on the aquifer. The RWMC Production well also had increasing trends for trichloroethene, trichloromethane, tetrachloroethene, 1,1,1-trichloroethane, and tribromomethane.

\section{References Cited}

\author{
Ackerman, D.J., 1991a, Transmissivity of the Snake \\ River Plain aquifer at the Idaho National Engineering \\ Laboratory, Idaho: U.S. Geological Survey Water-Resources \\ Investigations Report 91-4058 (DOE/ID-22097), 35 p., \\ http://pubs.er.usgs.gov/publication/wri914058. \\ Ackerman, D.J., 1991b, Transmissivity of perched aquifers \\ at the Idaho National Engineering Laboratory, Idaho: \\ U.S. Geological Survey Water-Resources Investigations \\ Report 91-4114 (DOE/ ID-22099), 27 p., http://pubs.er.usgs. \\ gov/usgspubs/wri/wri914114.
}


Ackerman, D.J., Rattray, G.W., Rousseau, J.P., Davis, L.C., and Orr, B.R., 2006, A conceptual model of ground-water flow in the eastern Snake River Plan aquifer at the Idaho National Laboratory and vicinity with implications for contaminant transport: U.S. Geological Survey Scientific Investigations Report 2006-5122, 62 p., http://pubs.usgs. gov/sir/2006/5122/.

Ackerman, D.J., Rousseau, J.P., Rattray, G.W., and Fisher, J.C., 2010, Steady-state and transient models of groundwater flow and advective transport, eastern Snake River Plain aquifer, Idaho National Laboratory and vicinity, Idaho: U.S. Geological Survey Scientific Investigations Report 2010-5123 (DOE/ID-22209), 220 p., http://pubs. usgs.gov/sir/2010/5123/.

Anderson, S.R., 1991, Stratigraphy of the unsaturated zone and uppermost part of the Snake River Plain aquifer at the Idaho Chemical Processing Plant and Test Reactors Area, Idaho National Engineering Laboratory, Idaho: U.S. Geological Survey Water-Resources Investigations Report 91-4010 (DOE/ID-22095), 71 p., http://pubs.er.usgs. gov/publication/wri914010.

Anderson, S.R., and Lewis, B.D., 1989, Stratigraphy of the unsaturated zone at the Radioactive Waste Management Complex, Idaho National Engineering Laboratory, Idaho: U.S. Geological Survey Water-Resources Investigations Report 89-4065 (DOE/ID-22080), 54 p., http://pubs.er.usgs. gov/publication/wri894065.

Barraclough, J.T., and Jensen, R.G., 1976, Hydrologic data for the Idaho National Engineering Laboratory site, Idaho, 1971 to 1973: U.S. Geological Survey Open-File Report 75-318 (IDO-22055), 52 p., http://pubs.er.usgs.gov/publication/ ofr75318.

Barraclough, J.T., Lewis, B.D., and Jensen, R.G., 1981, Hydrologic conditions at the Idaho National Engineering Laboratory, Idaho, emphasis 1974-1978: U.S. Geological Survey Water-Resources Investigations Open-File Report 81-526 (IDO-22060), 122 p.

Barraclough, J.T., Robertson, J.B., and Janzer, V.J., 1976, Hydrology of the solid waste burial ground as related to the potential migration of radionuclides, Idaho National Engineering Laboratory, with a section on drilling and sample analyses, by L.G. Saindon: U.S. Geological Survey Open-File Report 76-471 (IDO-22056), 183 p.

Barraclough, J.T., Teasdale, W.E., and Jensen, R.G., 1967a, Hydrology of the National Reactor Testing Station, Idaho, 1965: U.S. Geological Survey Open-File Report (IDO22048), 107 p.

Barraclough, J.T., Teasdale, W.E., Robertson, J.B., and Jensen, R.G., 1967b, Hydrology of the National Reactor Testing Station, Idaho, 1966: U.S. Geological Survey Open-File Report 67-12 (IDO-22049), 98 p.
Bartholomay, R.C., 1993, Concentrations of tritium and strontium-90 in water from selected wells at the Idaho National Engineering Laboratory after purging one, two, and three borehole volumes: U.S. Geological Survey WaterResources Investigations Report 93-4201 (DOE/ID-22111), 21 p., http://pubs.er.usgs.gov/usgspubs/wri/wri934201.

Bartholomay, R.C., 1998, Distribution of selected radiochemical and chemical constituents in perched ground water, Idaho National Engineering Laboratory, Idaho, 1992-95: U.S. Geological Survey Water-Resources Investigations Report 98-4026 (DOE/ID-22145), 59 p., http://pubs.er.usgs.gov/publication/wri984026.

Bartholomay, R.C., 2013, Iodine-129 in the Snake River Plain aquifer at and near the Idaho National Laboratory, Idaho, 2010-12: U.S. Geological Survey Scientific Investigations Report 2013-5195, 22 p., http://pubs.usgs. gov/sir/2013/5195/.

Bartholomay, R.C., Davis, L.C., Fisher, J.C., Tucker, B.J., and Raben, F.A., 2012, Water-quality characteristics and trends for selected sites at and near the Idaho National Laboratory, Idaho, 1949-2009: U.S. Geological Survey Scientific Investigations Report 2012-5169 (DOE/ID 22219), 68 p., http://pubs.usgs.gov/sir/2012/5169/.

Bartholomay, R.C., Knobel, L.L., and Rousseau, J.P., 2003, Field methods and quality-assurance plan for qualityof-water activities, U.S. Geological Survey, Idaho National Engineering and Engineering Laboratory, Idaho: U.S. Geological Survey Open-File Report 2003-42 (DOE/ ID-22182), 45 p., http://pubs.er.usgs.gov/publication/ ofr0342.

Bartholomay, R.C., Maimer, N.V., and Wehnke, A.J., 2014, Field methods and quality-assurance plan for water-quality activities and water-level measurements, U.S. Geological Survey, Idaho National Laboratory, Idaho: U.S. Geological Survey Open-File Report 2014-1146 (DOE/ID-22230), 66 p., http://pubs.usgs.gov/of/2014/1146/.

Bartholomay, R.C., Orr, B.R., Liszewski, M.J., and Jensen, R.G., 1995, Hydrologic conditions and distribution of selected radiochemical and chemical constituents in water, Snake River Plain aquifer, Idaho National Engineering Laboratory, Idaho, 1989 through 1991: U.S. Geological Survey Water-Resources Investigations Report 95-4175 (DOE/ID-22123), 47 p.

Bartholomay, R.C., and Tucker, B.J., 2000, Distribution of selected radiochemical and chemical constituents in perched ground water, Idaho National Engineering and Environmental Laboratory, Idaho, 1996-98: U.S. Geological Survey Water-Resources Investigations Report 2000-4222 (DOE/ID-22168), 51 p., http://pubs.er.usgs.gov/ publication/wri004222. 
Bartholomay, R.C., Tucker, B.J., Ackerman, D.J., and Liszewski, M.J., 1997, Hydrologic conditions and distribution of selected radiochemical and chemical constituents in water, Snake River Plain aquifer, Idaho National Engineering Laboratory, Idaho, 1992 through 1995: U.S. Geological Survey Water-Resources Investigations Report 97-4086 (DOE/ID-22137), 57 p., http://pubs.er.usgs.gov/publication/wri974086.

Bartholomay, R.C., Tucker, B.J., Davis, L.C., and Green, M.R., 2000, Hydrologic conditions and distribution of selected constituents in water, Snake River Plain aquifer, Idaho National Engineering and Environmental Laboratory, Idaho, 1996 through 1998: U.S. Geological Survey WaterResources Investigations Report 2000-4192 (DOE/ ID-22167), 52 p., http://pubs.er.usgs.gov/publication/ wri004192.

Bartholomay, R.C., and Williams, L.M., 1996, Evaluation of preservation methods for selected nutrients in ground water at the Idaho National Engineering Laboratory, Idaho: U.S. Geological Survey Water-Resources Investigations Report 96-4260 (DOE/ID-22131), 16 p., http://pubs. er.usgs.gov/publication/wri964260.

Bodnar, L.Z., and Percival, D.R., eds., 1982, Analytical Chemistry Branch procedures manual-Radiological and Environmental Sciences Laboratory: U.S. Department of Energy Report IDO-12096 [variously paged].

Busenberg, Eurybiades, Plummer, L.N., and Bartholomay, R.C., 2001, Estimated age and source of the young fraction of ground water at the Idaho National Engineering and Environmental Laboratory: U.S. Geological Survey Water-Resources Investigations Report 2001-4265 (DOE/ID-22177), 144 p., http://pubs. er.usgs.gov/publication/wri014265.

Cecil, L.D., Orr, B.R., Norton, T.J., and Anderson, S.R., 1991, Formation of perched ground-water zones and concentrations of selected chemical constituents in water, Idaho National Engineering Laboratory, Idaho, 1986-88: U.S. Geological Survey Water-Resources Investigations Report 91-4166 (DOE/ID-22100), 53 p., http://pubs. er.usgs.gov/publication/wri914166.

Cecil, L.D., Welhan, J.A., Green, J.R., Frape, S.K., and Sudicky, E.R., 2000, Use of chlorine-36 to determine regional-scale aquifer dispersivity, eastern Snake River Plain aquifer, Idaho/USA: Nuclear Instruments and Methods in Physics Research, section B, v. 172, issues 1-4, p. 679-687.
Childress, C.J.O., Forman, W.T., Connor, B.F., and Maloney, T.J., 1999, New reporting procedures based on longterm method detection levels and some considerations for interpretations of water-quality data provided by the U.S. Geological Survey National Water Quality Laboratory: U.S. Geological Survey Open-File Report 99-193, 19 p., http://pubs.er.usgs.gov/publication/ofr99193.

Claassen, H.C., 1982, Guidelines and techniques for obtaining water samples that accurately represent the water chemistry of an aquifer: U.S. Geological Survey Open-File Report 82-1024, 49 p., http://pubs.er.usgs.gov/publication/ ofr821024.

Currie, L.A., 1984, Lower limit of detection-definition and elaboration of a proposed position for radiological effluent and environmental measurements: U.S. Nuclear Regulatory Commission NUREG/CR-4007, 139 p.

Davis, L.C., 2006a, An update of the distribution of selected radiochemical and chemical constituents in perched ground water, Idaho National Laboratory, Idaho, emphasis 19992001: U.S. Geological Survey Scientific Investigations Report 2006-5236 (DOE/ID-22199), 48 p., http://pubs.usgs. gov/sir/2006/5236/.

Davis, L.C., 2006b, An update of hydrologic conditions and distribution of selected constituents in water, Snake River Plain aquifer, Idaho National Laboratory, Idaho, emphasis 1999-2001: U.S. Geological Survey Scientific Investigations Report 2006-5088 (DOE/ID-22197), 48 p., http://pubs.usgs.gov/sir/2006/5088/.

Davis, L.C., 2008, An update of hydrologic conditions and distribution of selected constituents in water, Snake River Plain aquifer and perched-water zones, Idaho National Laboratory, Idaho, emphasis 2002-05: U.S. Geological Survey Scientific Investigations Report 2008-5089 (DOE/ ID-22203), 75 p., http://pubs.usgs.gov/sir/2008/5089/.

Davis, L.C., 2010, An update of hydrologic conditions and distribution of selected constituents in water, Snake River Plain aquifer and perched groundwater zones, Idaho National Laboratory, Idaho, emphasis 2006-08: U.S. Geological Survey Scientific Investigations Report 2010-5197 (DOE/ID-22212), 80 p., http://pubs.usgs.gov/ $\operatorname{sir} / 2010 / 5197 /$.

Davis, L.C.; Bartholomay, R.C.; Rattray, G.W., 2013, An update of hydrologic conditions and distribution of selected constituents in water, eastern Snake River Plain aquifer and perched groundwater zones, Idaho National Laboratory, Idaho, emphasis 2009-11: USGS Scientific Investigations Report: 2013-5214 (DOE/ID 22226), 89 p., http://pubs.usgs. gov/sir/2013/5214/. 
Duke, C.L., Roback, R.C., Reimus, P.W., Bowman, R.S., McLing, T.L., Baker, K.E., and Hull, L.C., 2007, Elucidation of flow and transport processes in a variably saturated system of interlayered sediment and fractured rock using tracer tests: Vadose Zone Journal, v. 6, no. 4, p. 855-867.

Faires, L.M., 1993, Methods of analysis by the U.S. Geological Survey National Water Quality LaboratoryDeterminations of metals in water by inductively coupled plasma-mass spectrometry: U.S. Geological Survey Open-File Report 92-634, 28 p., http://pubs.er.usgs.gov/ publication/ofr92634.

Fisher, J.C., and Davis, L.C., 2014, Analysis of data collected from a monitoring network, Package 'Trends'-version 0.20: GitHub, Inc., accessed August 6, 2014 at https://github. com/jfisher-usgs/Trends.

Fisher, J.C., Rousseau, J.P., Bartholomay, R.C, and Rattray, G.W., 2012, A comparison of U.S. Geological Survey threedimensional model estimates of groundwater source areas and velocities to independently derived estimates, Idaho National Laboratory and vicinity, Idaho: U.S. Geological Survey Scientific Investigations Report 2012-5152 (DOE/ID-22218), 130 p., http://pubs.usgs.gov/ $\operatorname{sir} / 2012 / 5152 /$.

Fishman, M.J., ed., 1993, Methods of analysis by the U.S. Geological Survey National Water Quality LaboratoryDetermination of inorganic and organic constituents in water and fluvial sediments: U.S. Geological Survey Open-File Report 93-125, 217 p., http://pubs.er.usgs.gov/ publication/ofr93125.

Fishman, M.J., and Friedman, L.C., eds., 1989, Methods for determination of inorganic substances in water and fluvial sediments ( $3 \mathrm{~d}$ ed.): U.S. Geological Survey Techniques of Water-Resources Investigations, book 5, chap. A1, 545 p., http://pubs.usgs.gov/twri/twri5-a1/.

Forbes, J.R., Ansley, S.L., and Leecaster, Molly, 2007, INTEC groundwater monitoring report (2006): U.S. Department of Energy, Idaho Operation Office Publication, DOE/ ID-11301, rev. 0, $134 \mathrm{p}$.

French, D.L., Tallman, R.E., and Taylor, K.A., 1999, Idaho National Engineering Laboratory nonradiological waste management information for 1998 and record-to-date: U.S. Department of Energy, Waste Management Programs Division, Idaho Operations Office Publication, DOE/ ID-10057 (98) [variously paged].

Garabedian, S.P., 1986, Application of a parameter-estimation technique to modeling the regional aquifer underlying the eastern Snake River Plain, Idaho: U.S. Geological Survey Water-Supply Paper 2278, 60 p., http://pubs.er.usgs.gov/ publication/wsp2278.
Goerlitz, D.F., and Brown, Eugene, 1972, Methods for analysis of organic substances in water: U.S. Geological Survey Techniques of Water-Resources Investigations, book 5, chap. A3, 40 p., http://pubs.er.usgs.gov/publication/ twri05A3_1972.

Hem, J.D., 1989, Study and interpretation of the chemical characteristics of natural water ( $3 \mathrm{~d}$ ed.): U.S. Geological Survey Water-Supply Paper 2254, 263 p.

Hull, L.C., 1989, Conceptual model and description of the affected environment for the TRA warm waste pond (Waste Management Unit TRA-03): EG and G Idaho Informal Report EGG-ER-8644, 125 p.

Knobel, L.L., 2006, Evaluation of well-purging effects on water-quality results for samples collected from the eastern Snake River Plain aquifer underlying the Idaho National Laboratory, Idaho: U.S. Geological Survey Scientific Investigations Report 2006-5232 (DOE/ID-22200), 52 p., http://pubs.usgs.gov/sir/2006/5232/.

Knobel, L.L., Tucker, B.J. and Rousseau, J.P., 2008, Field methods and quality-assurance plan for quality-ofwater activities, U.S. Geological Survey, Idaho National Laboratory, Idaho: U.S. Geological Survey Open-File Report 2008-1165 (DOE/ID-22206), 36 p., http://pubs. usgs.gov/of/2008/1165/.

Lewis, B.D., and Jensen, R.G., 1985, Hydrologic conditions at the Idaho National Engineering Laboratory, Idaho, 1979-1981 update: U.S. Geological Survey Hydrologic Investigations Atlas HA-674, 2 sheets.

Mann, L.J., 1986, Hydraulic properties of rock units and chemical quality of water for INEL-1-A 10,365-foot deep test hole drilled at the Idaho National Engineering Laboratory, Idaho: U.S. Geological Survey Water-Resources Investigations Report 86-4020 (DOE/ID-22070), 23 p., http://pubs.er.usgs.gov/publication/wri864020.

Mann, L.J., 1996, Quality-assurance plan and field methods for quality-of-water activities, U.S. Geological Survey, Idaho National Engineering Laboratory, Idaho: U.S. Geological Survey Open-File Report 96-615 (DOE/ ID-22132), 37 p., http://pubs.er.usgs.gov/publication/ ofr96615.

Mann, L.J., and Knobel, L.L., 1987, Purgeable organic compounds in ground water at the Idaho National Engineering Laboratory, Idaho: U.S. Geological Survey Open-File Report 87-766 (DOE/ID-22074), 23 p., http:// pubs.er.usgs.gov/publication/ofr87766. 
Mann, L.J., and Beasley, T.M., 1994, Iodine-129 in the Snake River Plain aquifer at and near the Idaho National Engineering Laboratory, Idaho, 1990-1991: U.S. Geological Survey Water-Resources Investigations Report 94-4053 (DOE/ID-22115), 27 p., http://pubs.er.usgs.gov/publication/ wri944053.

McCurdy, D.E., Garbarino, J.R., and Mullin, A.H., 2008, Interpreting and reporting radiological water-quality data: U.S. Geological Survey Techniques and Methods, book 5, chap. B6, 33 p., http://pubs.usgs.gov/tm/05b06/.

Morris, D.A., Barraclough, J.T., Chase, G.H., Teasdale, W.E., and Jensen, R.G., 1965, Hydrology of subsurface waste disposal, National Reactor Testing Station, Idaho, annual progress report, 1964: U.S. Atomic Energy Commission, Idaho Operations Office Publication, IDO-22047-USGS, $186 \mathrm{p}$.

Morris, D.A., Barraclough, J.T., Hogenson, G.M., Shuter, Eugene, Teasdale, W.E., Ralston, D.A., and Jensen, R.G., 1964, Hydrology of subsurface waste disposal, National Reactor Testing Station, Idaho, annual progress report, 1963: U.S. Atomic Energy Commission, Idaho Operations Office Publication, IDO-22046-USGS, 97 p.

Morris, D.A., Hogenson, G.M., Shuter, Eugene, and Teasdale, W.E., 1963, Hydrology of waste disposal, National Reactor Testing Station, Idaho, annual progress report, 1962: U.S. Atomic Energy Commission, Idaho Operations Office Publication, IDO-22044-USGS, 99 p.

Nace, R.L., Voegeli, P.T., Jones, J.R., and Deutsch, Morris, 1975, Generalized geologic framework of the National Reactor Testing Station, Idaho: U.S. Geological Survey Professional Paper 725-B, 48 p., http://pubs.er.usgs.gov/ publication/pp725B.

Neher, E.R., Fredrick, D.B., and Johnson, G.S., 1998, Water quality trends in the Snake River Plain aquifer at the Idaho National Engineering and Environmental Laboratory, 1960 to 1995: State of Idaho Research Technical Completion Report 98-1, 62 p. and appendices.

Nimmo, J.R., Perkins, K.S., Rose, P.A., Rousseau, J.P., Orr, B.R., Twining, B.V., and Anderson, S.R., 2002, Kilometerscale rapid transport of naphthalene sulfonate tracer in the unsaturated zone at the Idaho National Engineering and Environmental Laboratory: Vadose Zone Journal, v. 1, issue 1, p. 89-101.

Olmsted, F.H., 1962, Chemical and physical character of ground water in the National Reactor Testing Station, Idaho: U.S. Atomic Energy Commission, Idaho Operations Office Publication IDO-22043-USGS, 142 p.
Orr, B.R., 1999, A transient numerical simulation of perched ground-water flow at the Test Reactor Area, Idaho National Engineering and Environmental Laboratory, Idaho, 1952-94: U.S. Geological Survey Water-Resources Investigations Report 99-4277 (DOE/ID-22162), 54 p., http://pubs.er.usgs.gov/publication/wri994277.

Orr, B.R., and Cecil, L.D., 1991, Hydrologic conditions and distribution of selected chemical constituents in water, Snake River Plain aquifer, Idaho National Engineering Laboratory, Idaho, 1986 to 1988: U.S. Geological Survey Water-Resources Investigations Report 91-4047 (DOE/ ID-22096), 56 p., http://pubs.er.usgs.gov/publication/ wri914047.

Orr, B.R., Cecil, L.D., and Knobel, L.L., 1991, Background concentrations of selected radionuclides, organic compounds, and chemical constituents in ground water in the vicinity of the Idaho National Engineering Laboratory: U.S. Geological Survey Water-Resources Investigations Report 91-4015 (DOE/ID-22094), 52 p., http://pubs. er.usgs.gov/publication/wri914015.

Perkins, K.S., and Winfield, K.A., 2007, Property-transfer modeling to estimate unsaturated hydraulic conductivity of deep sediments at the Idaho National Laboratory, Idaho: U.S. Geological Survey Scientific Investigations Report 2007-5093 (DOE/ID-22202), 22 p., http://pubs.usgs.gov/ $\operatorname{sir} / 2007 / 5093 /$.

Pittman, J.R., Fischer, P.R., and Jensen, R.G., 1988, Hydrologic conditions at the Idaho National Engineering Laboratory, 1982 to 1985: U.S. Geological Survey WaterResources Investigations Report 89-4008 (DOE/ID-22078), 73 p., http://pubs.er.usgs.gov/publication/wri894008.

Plummer, L.N., Rupert, M.G., Busenberg, Eurybiades, and Schlosser, P., 2000, Age of irrigation water in ground water from the eastern Snake River Plain aquifer, South-central Idaho: Ground Water, v. 38, no. 2, p. 264-283.

Pritt, J. W., 1989, Quality assurance of sample containers and preservatives at the U.S. Geological Survey National Water Quality Laboratory, in Pederson, G.L., and Smith, M.M., compilers, U.S. Geological Survey Second National Symposium on Water Quality-Abstracts of the Technical Sessions: U.S. Geological Survey Open-File Report 89-409, 111 p., http://pubs.er.usgs.gov/publication/ofr89409.

R Development Core Team, 2014, A language and environment for statistical computing, ISBN 3-90005107-0: The R Project for Statistical Computing Web site, accessed July 22, 2014 at http://www.R-project.org. 
Rattray, G.W., 2012, Evaluation of quality-control data collected by the U.S. Geological Survey for routine water-quality activities at the Idaho National Laboratory, Idaho, 1996-2001: USGS Scientific Investigations Report 2012-5270 (DOE/ID-22222), 74 p., http://pubs.er.usgs.gov/ publication/sir20125270.

Rattray, G.W., 2014, Evaluation of quality-control data collected by the U.S. Geological Survey for routine waterquality activities at the Idaho National Laboratory and vicinity, southeastern Idaho, 2002-08: USGS Scientific Investigations Report 2014-5027 (DOE/ID-22228), 66 p., http://pubs.usgs.gov/sir/2014/5027/.

Robertson, J.B., 1976, Numerical modeling of subsurface radioactive solute transport from waste seepage ponds at the Idaho National Engineering Laboratory: U.S. Geological Survey Open-File Report 76-717 (IDO-22057), 68 p.

Robertson, J.B., Schoen, Robert, and Barraclough, J.T., 1974, The influence of liquid waste disposal on the geochemistry of water at the National Reactor Testing Station, Idaho, 1952-1970: U.S. Geological Survey Open-File Report 73-238 (IDO-22053), 231 p., http://pubs.er.usgs.gov/ publication/ofr73238.

Sehlke, Gerald, and Bickford, F.E., 1993, Idaho National Engineering Laboratory ground-water monitoring plan: EG and G Idaho, Inc., and Golder Associates, Inc., DOE/ ID-10441, v. 1-2 [variously paged].

Stevens, H.H., Ficke, J.F., and Smoot, G.F., 1975, Water temperature - Influential factors, field measurement, and data presentation: U.S. Geological Survey Techniques of Water-Resources Investigations, book 1, chap. D1, 65 p., http://pubs.usgs.gov/twri/twri1-d1/.

Thatcher, L.L., Janzer, V.J., and Edwards, K.W., 1977, Methods for determination of radioactive substances in water and fluvial sediments: U.S. Geological Survey Techniques of Water-Resources Investigations, book 5, chap. A5, 95 p., http://pubs.usgs.gov/twri/twri5a5/.

Therneau, T.M., 2014, A Package for Survival Analysis in S., R package version 2.37-7: The Comprehensive $\mathrm{R}$ Archive Network, accessed at http://CRAN.R-project.org/ package $=$ survival.

Therneau, T.M. and Grambsch, P.M., 2000, Modeling survival data-Extending the Cox Model: New York, Springer, $350 \mathrm{p}$.

Timme, P.J., 1995, National Water Quality Laboratory, 1995 services catalog: U.S. Geological Survey Open-File Report 95-352, 120 p., http://pubs.er.usgs.gov/publication/ ofr95352.
Tucker, B.J., and Orr, B.R., 1998, Distribution of selected radiochemical and chemical constituents in perched ground water, Idaho National Engineering Laboratory, Idaho, 1989-91: U.S. Geological Survey Water-Resources Investigations Report 98-4028 (DOE/ID-22144), 62 p., http://pubs.er.usgs.gov/publication/wri984028.

U.S. Department of Energy, 1995, Radiochemistry manual, revision 10: Idaho Falls, Idaho, U.S. Department of Energy, Radiological and Environmental Sciences Laboratory [variously paged].

U.S. Department of Energy, 2010, Waste Area Group 10, operable unit 10-08, annual monitoring status report for Fiscal Year 2009: U.S. Department of Energy, DOE/ ID-11417, revision 0, unpaginated.

U.S. Department of Energy, 2011, Five-year review of CERCLA response actions at the Idaho National Laboratory site-Fiscal years 2005-2009: U.S. Department of Energy, DOE/ID-11429, Rev. 0, [variously paged].

U.S. Environmental Protection Agency, 2013, Protection of environment - Code of federal regulations 40, part 141, subpart $\mathrm{G}$, national primary drinking water regulations, maximum contaminant levels and maximum residual disinfectant levels: Washington, D.C., Office of the Federal Register, National Archives and Records Administration, accessed August 21, 2013, at http://www.ecfr.gov/cgi-bin/ret rieveECFR?gp $=\&$ SID $=3 \mathrm{a} 944 \mathrm{~d} 5 \mathrm{fa} 8 \mathrm{add}$ d9792af65c5d71a0c $\mathrm{cc} \& \mathrm{n}=40 \mathrm{y} 24.0 .1 .1 .3 \& \mathrm{r}=$ PART \& $\mathrm{ty}=\mathrm{HTML} \# 40: 24.0 .1 .1 .3 .7$.

U.S. Geological Survey, 1985, National water summary, 1984-Hydrologic events, selected water-quality trends, and ground-water resources: U.S. Geological Survey Water-Supply Paper 2275, 467 p., http://pubs.er.usgs.gov/ publication/wsp2275.

U.S. Geological Survey, 2010, Changes to the reporting convention and to data qualification approaches for selected analyte results reported by the National Water Quality Laboratory (NWQL): U.S Geological Survey Office of Water Quality Technical Memorandum 2010.07, accessed June 9, 2011, at http://water.usgs.gov/admin/memo/QW/ qw10.07.html.

U.S. Geological Survey, variously dated, National field manual for the collection of water-quality data: U.S. Geological Survey Techniques of Water-Resources Investigations, book 9, chaps. A1-A9., http://water.usgs. gov/owq/FieldManual/. 
Walker, F.W., Parrington, J.R., and Feiner, Frank, 1989, Nuclides and isotopes, chart of the nuclides (14th ed.): Fairfield, Connecticut, General Electric Company, Nuclear Energy Operations, $57 \mathrm{p}$.

Wegner, S.J., 1989, Selected quality assurance data for water samples collected by the U.S. Geological Survey, Idaho National Engineering Laboratory Idaho, 1980 to 1988: U.S. Geological Survey Water-Resources Investigations Report 89-4168 (DOE/ID-22085), 91 p., http://pubs.er.usgs.gov/ publication/wri894168.

Wershaw, R.L., Fishman, M.J., Grabbe, R.R., and Lowe, L.E., eds., 1987, Methods for the determination of organic substances in water and fluvial sediments (revised ed.): U.S. Geological Survey Techniques of Water-Resources Investigations, book 5, chap. A3, 80 p., http://pubs.er.usgs. gov/publication/twri05A3.
Williams, L.M., 1996, Evaluation of quality assurance/ quality control data collected by the U.S. Geological Survey for water-quality activities at the Idaho National Engineering Laboratory, Idaho, 1989 through 1993: U.S. Geological Survey Water-Resources Investigations Report 96-4148 (DOE/ID-22129), 116 p., http://pubs.er.usgs.gov/ publication/wri964148.

Williams, L.M., 1997, Evaluation of quality assurance/quality control data collected by the U.S. Geological Survey for water-quality activities at the Idaho National Engineering Laboratory, Idaho, 1994 through 1995: U.S. Geological Survey Water-Resources Investigations Report 97-4058 (DOE/ID-22136), 87 p., http://pubs.er.usgs.gov/publication/ wri974058.

Wood, W.W., 1976, Guidelines for collection and field analysis of ground-water samples for selected unstable constituents: U.S. Geological Survey Techniques of Water-Resources Investigations, book 1, chap. D2, 24 p., http://pubs.usgs. gov/twri/twri1-d2/. 

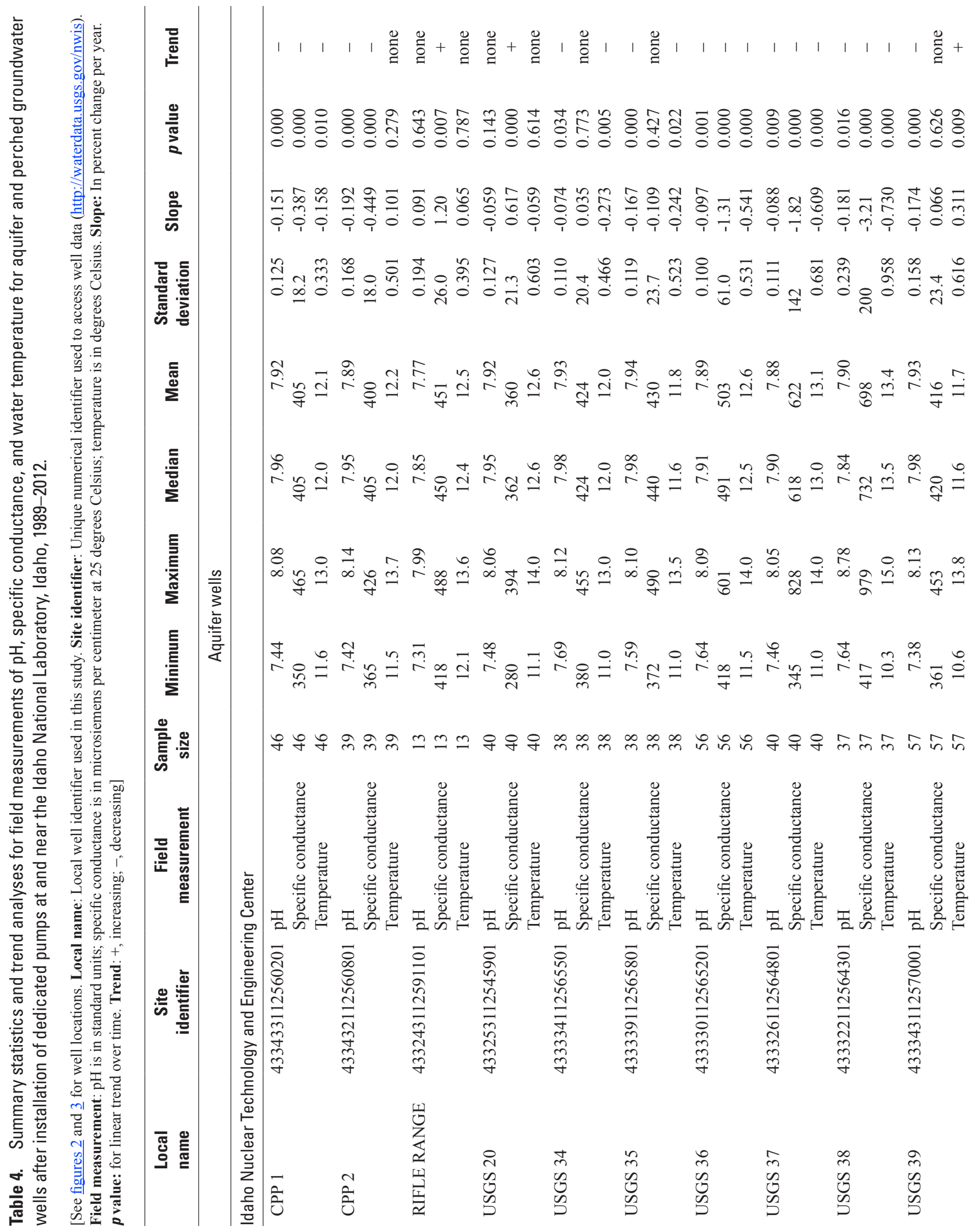


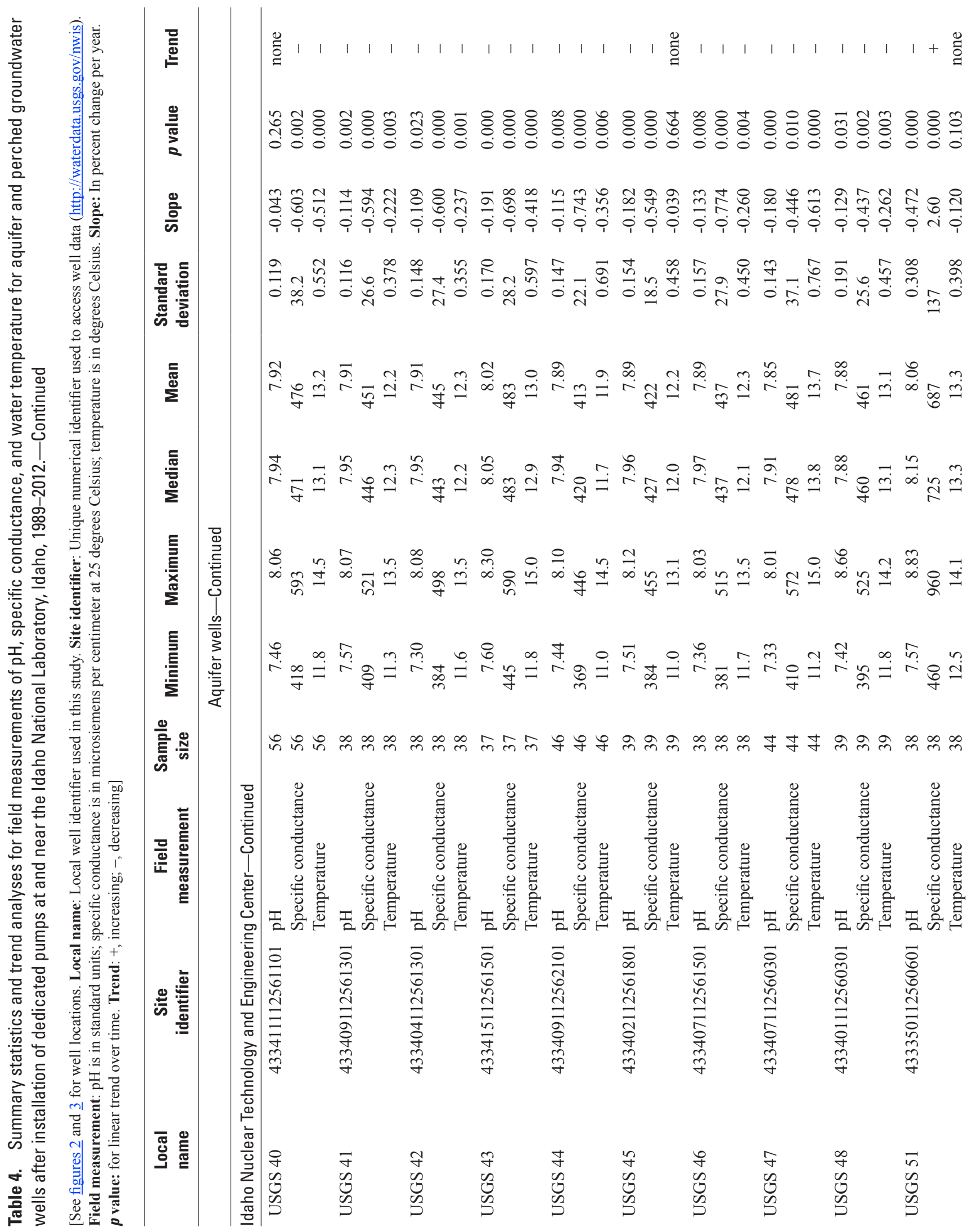




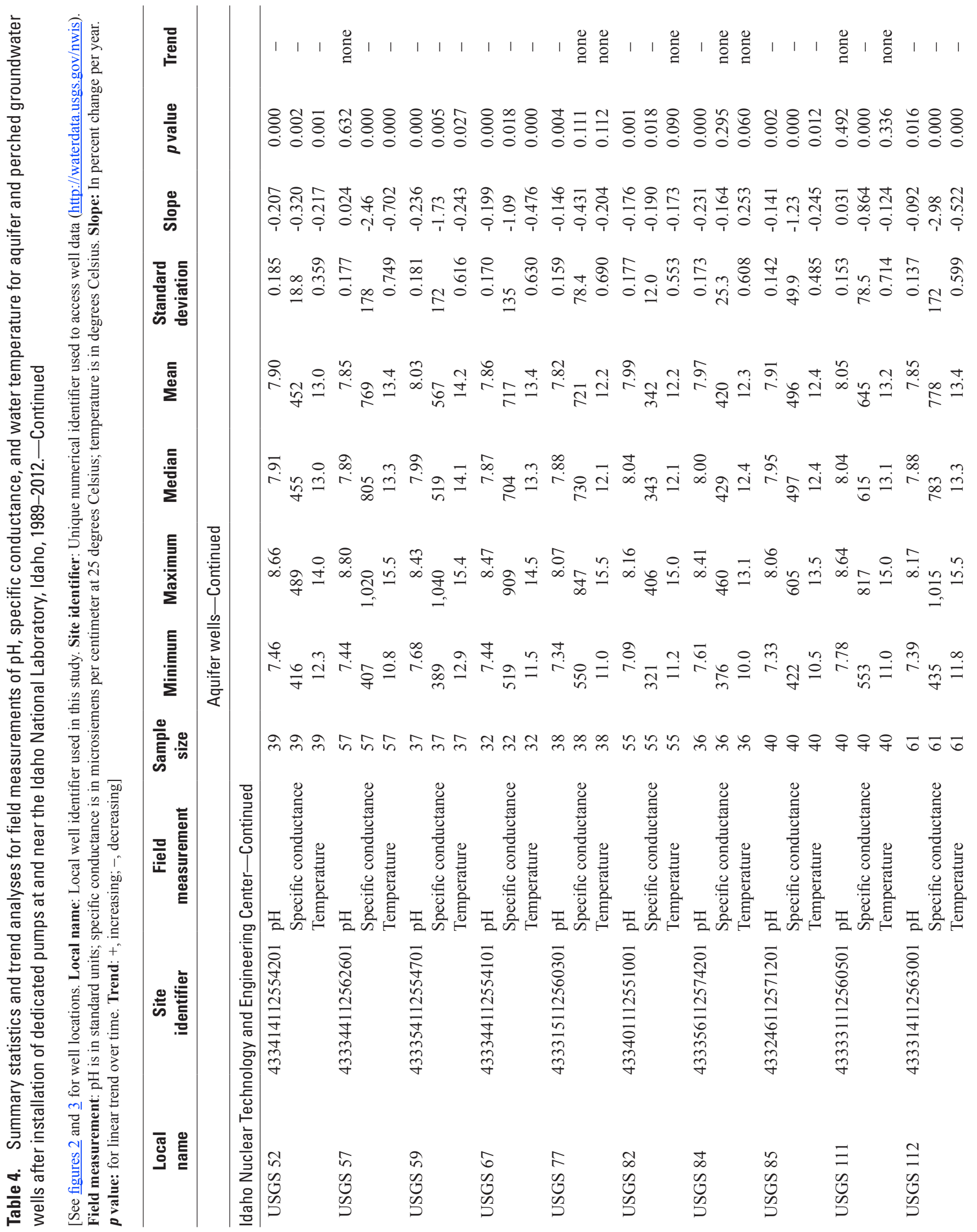




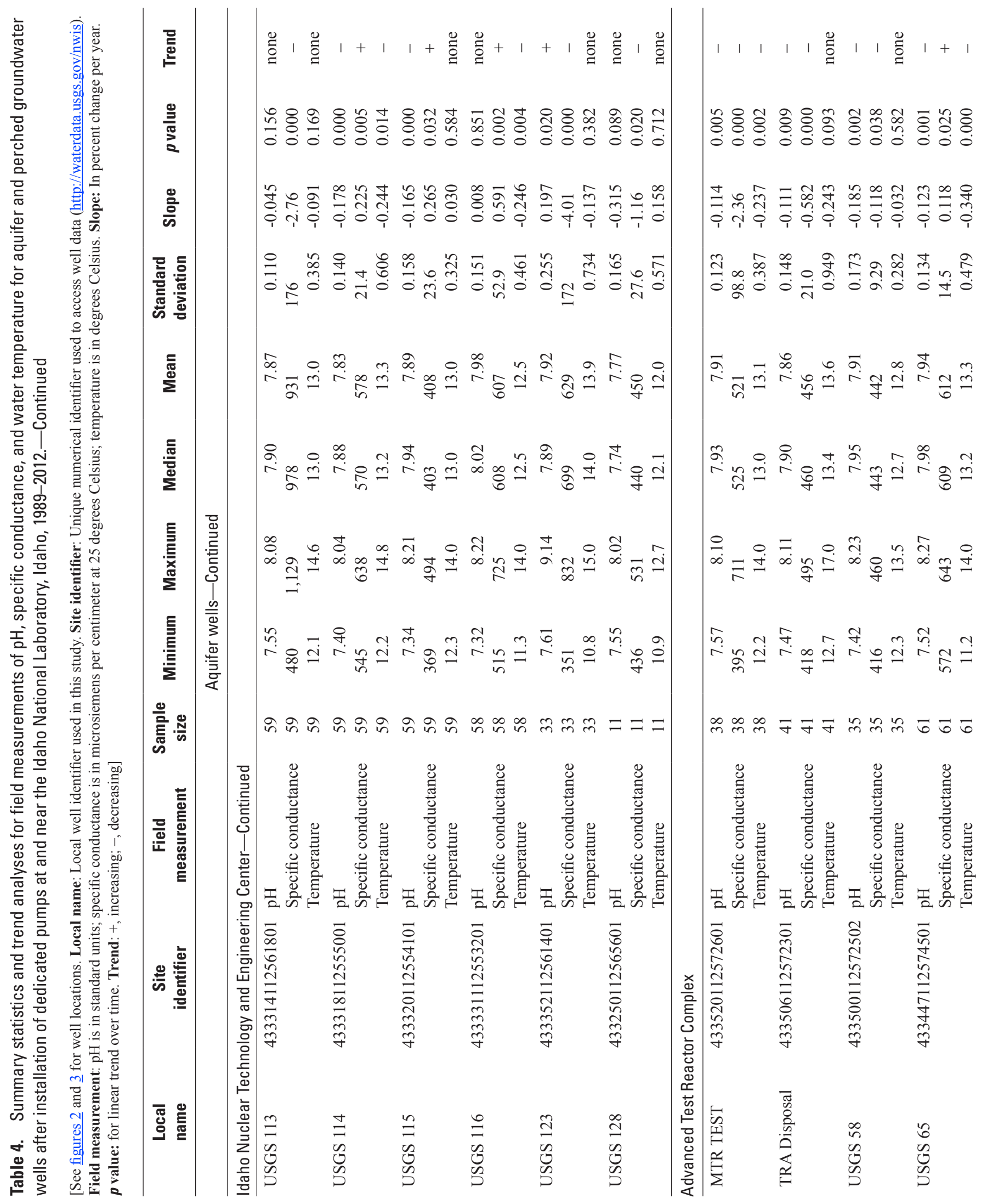




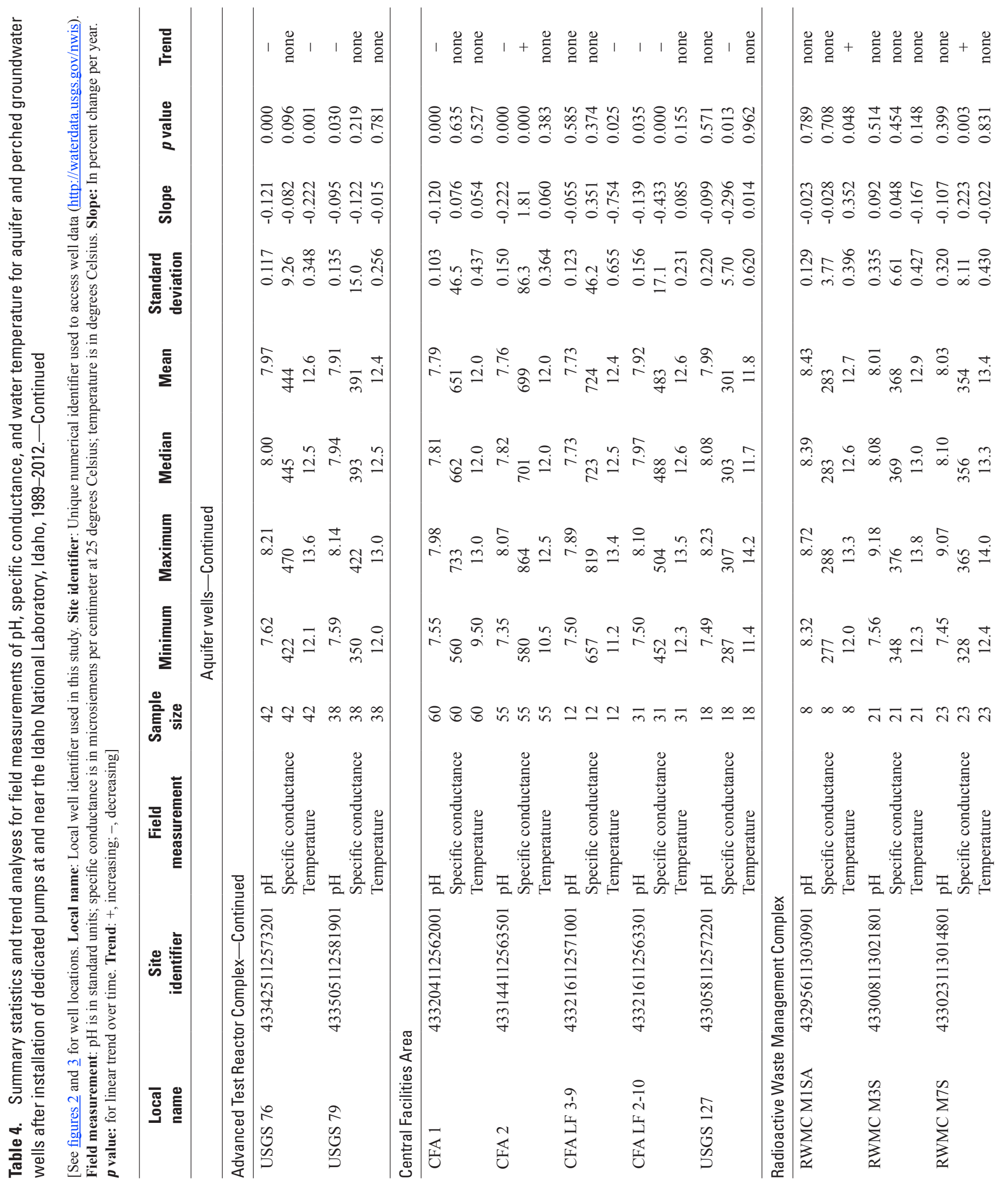




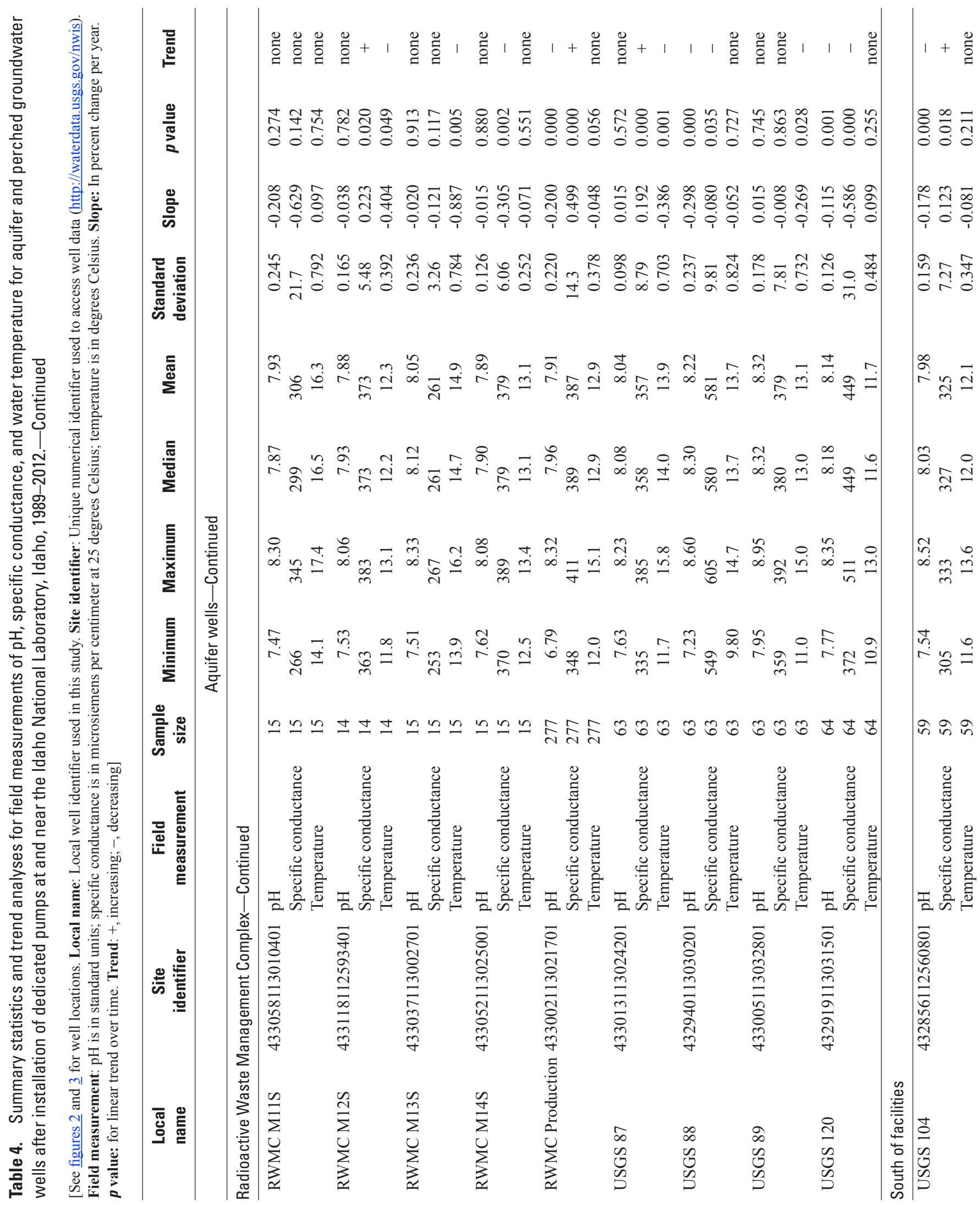




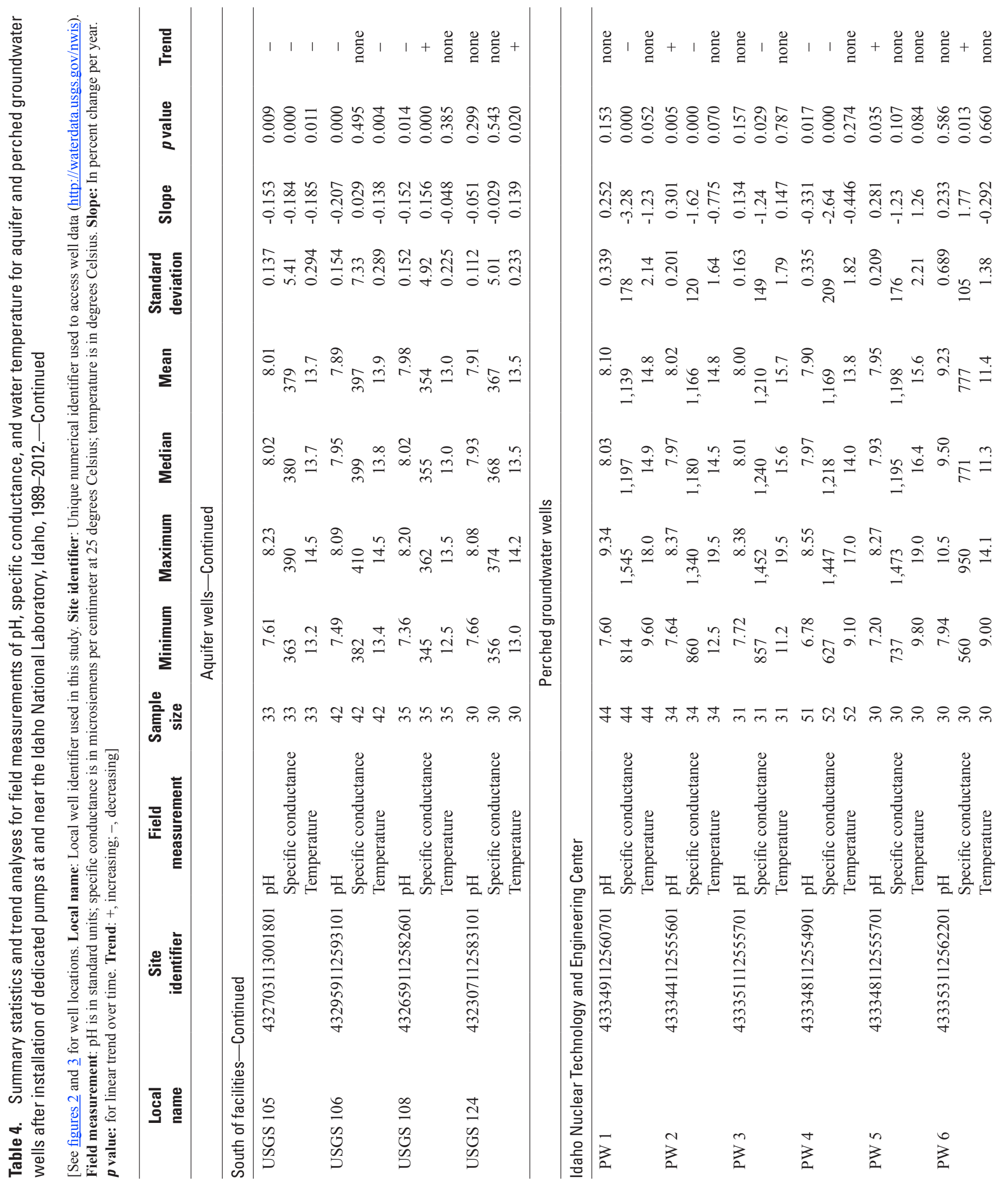




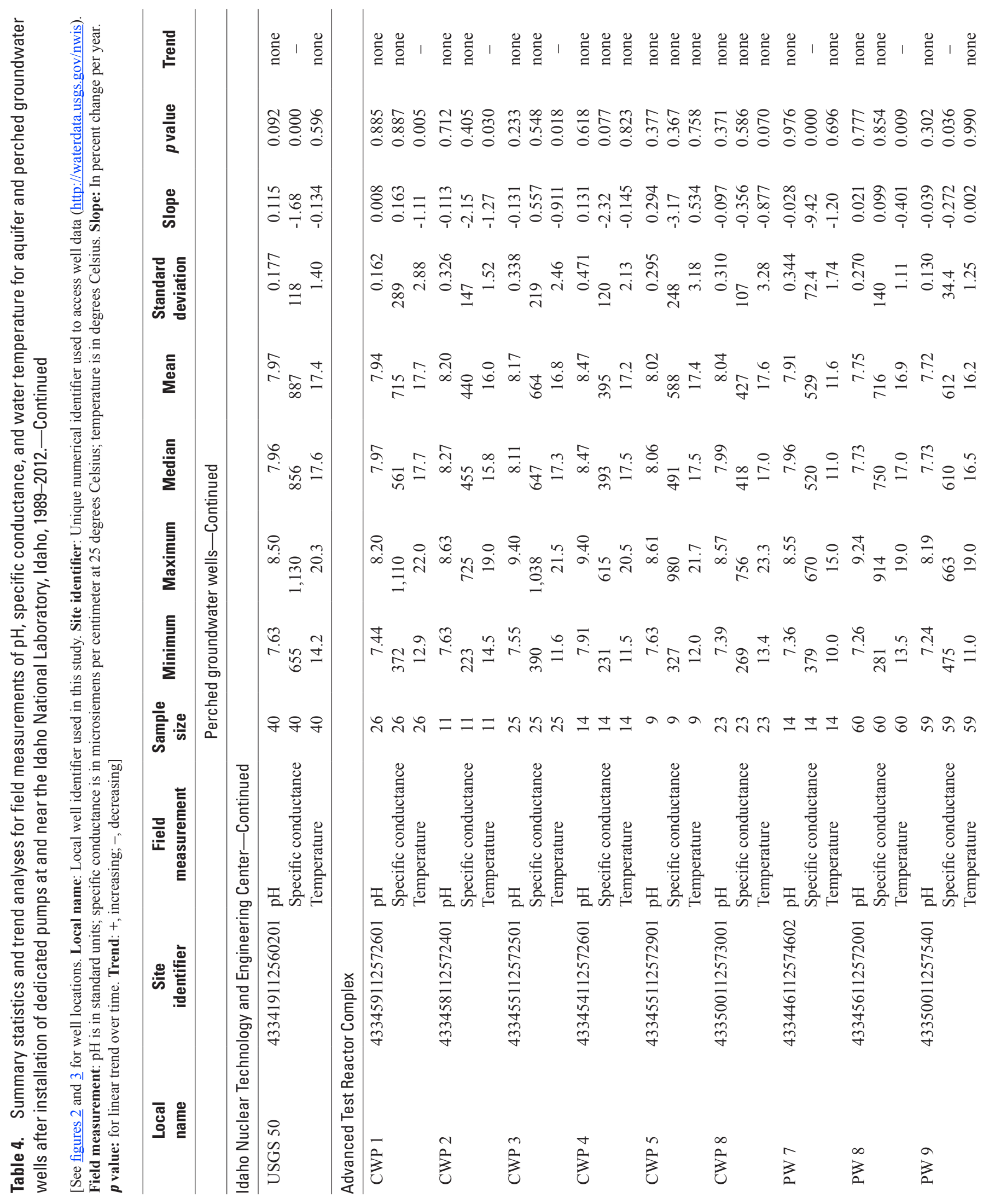




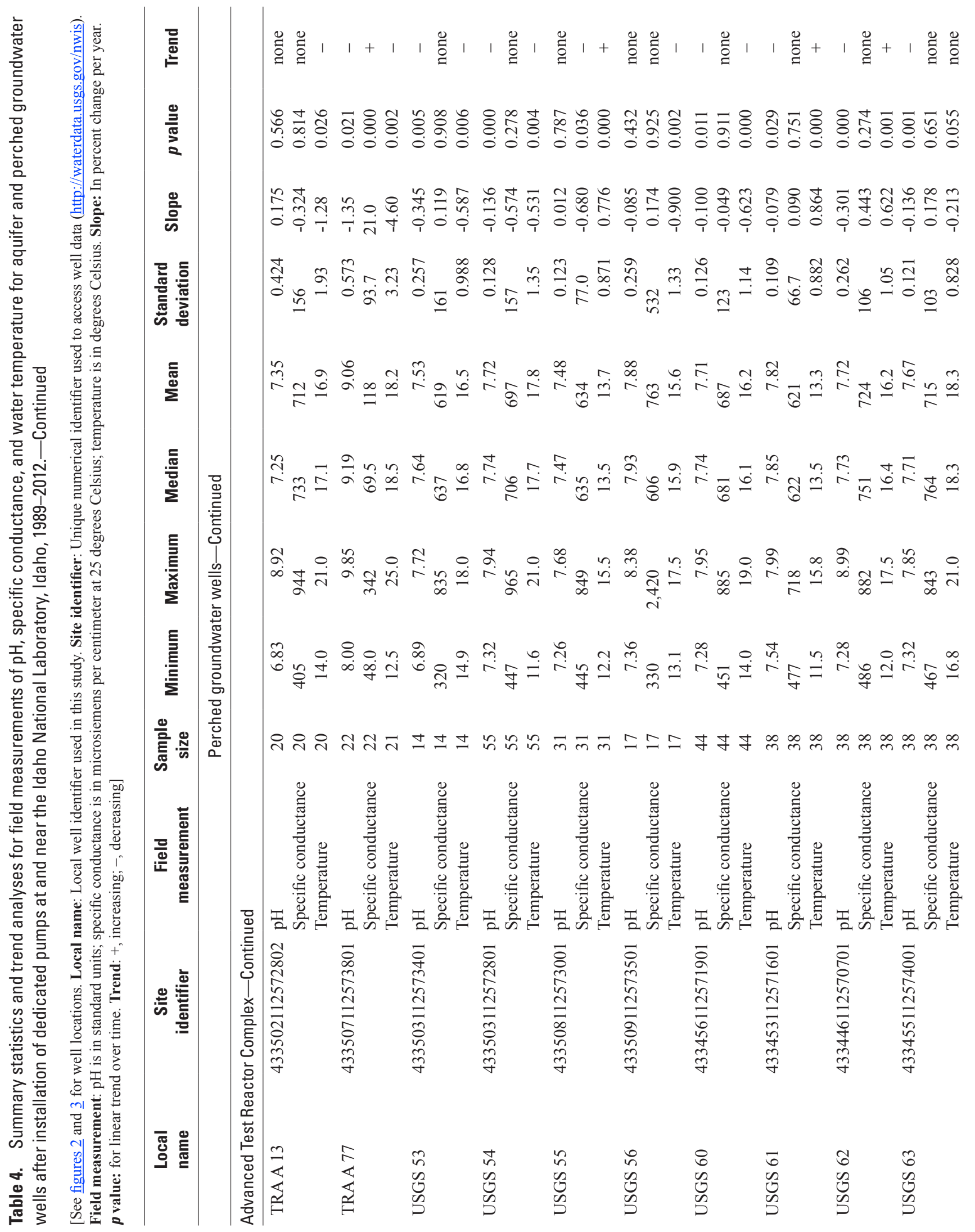




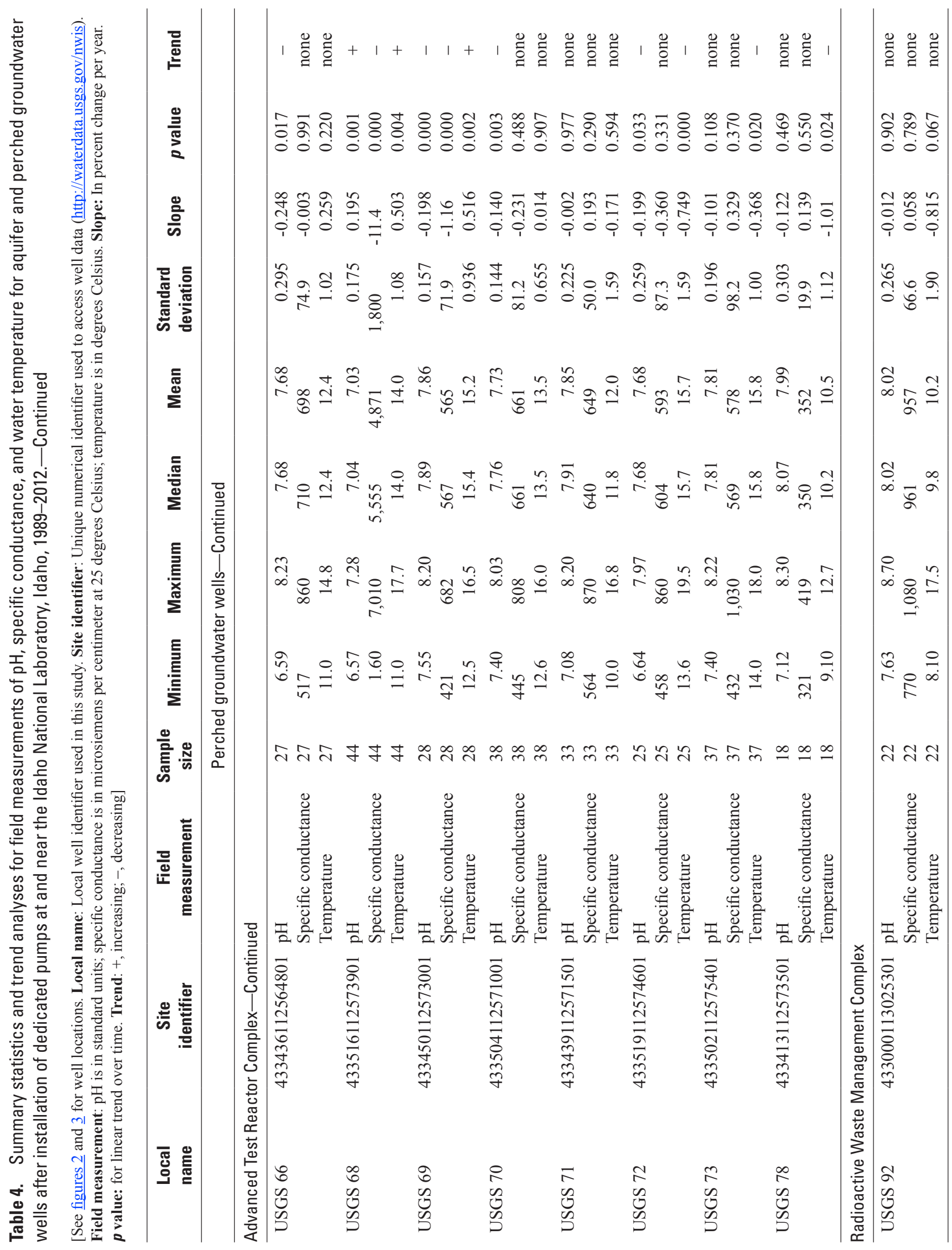




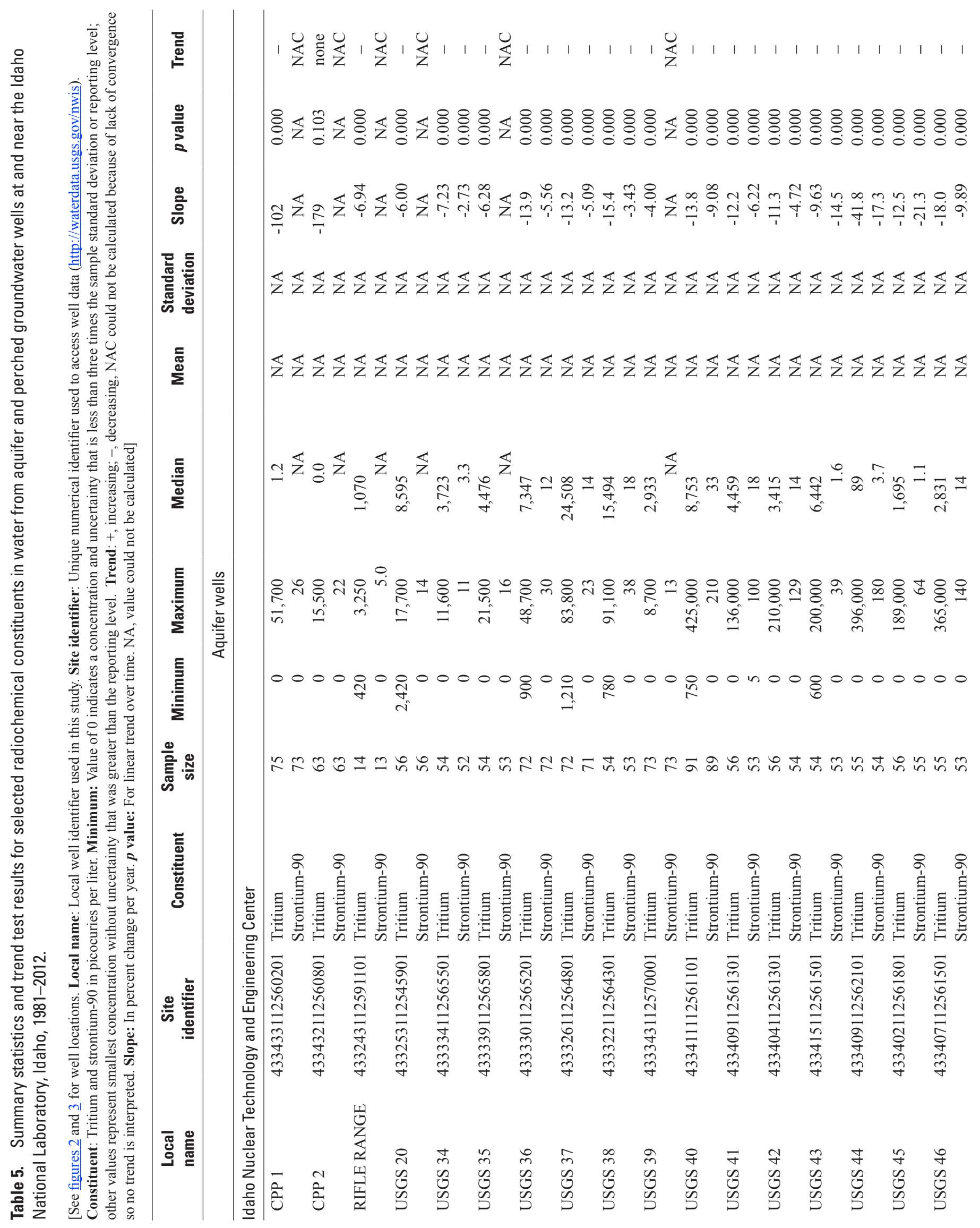




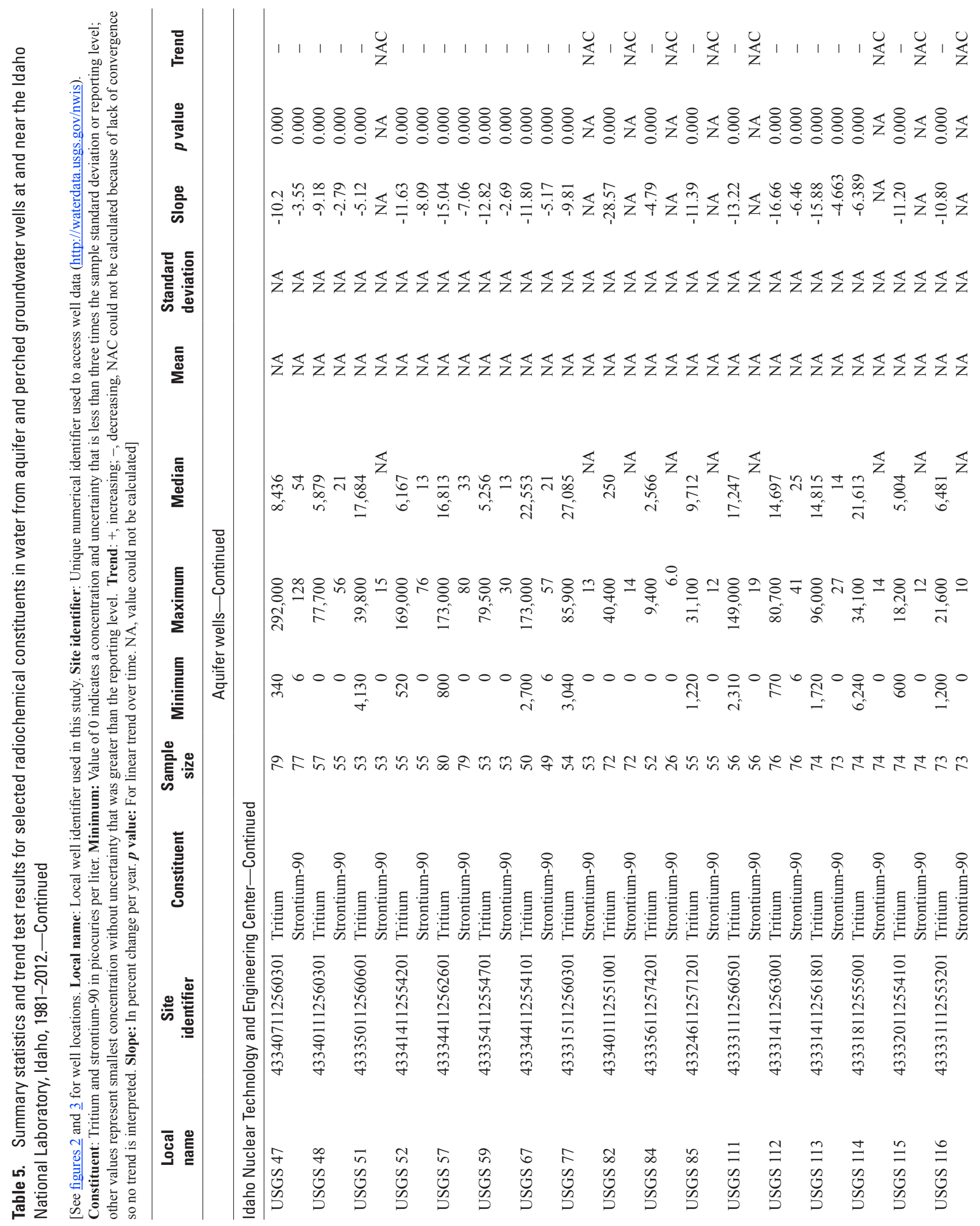


Table $5 \quad 75$

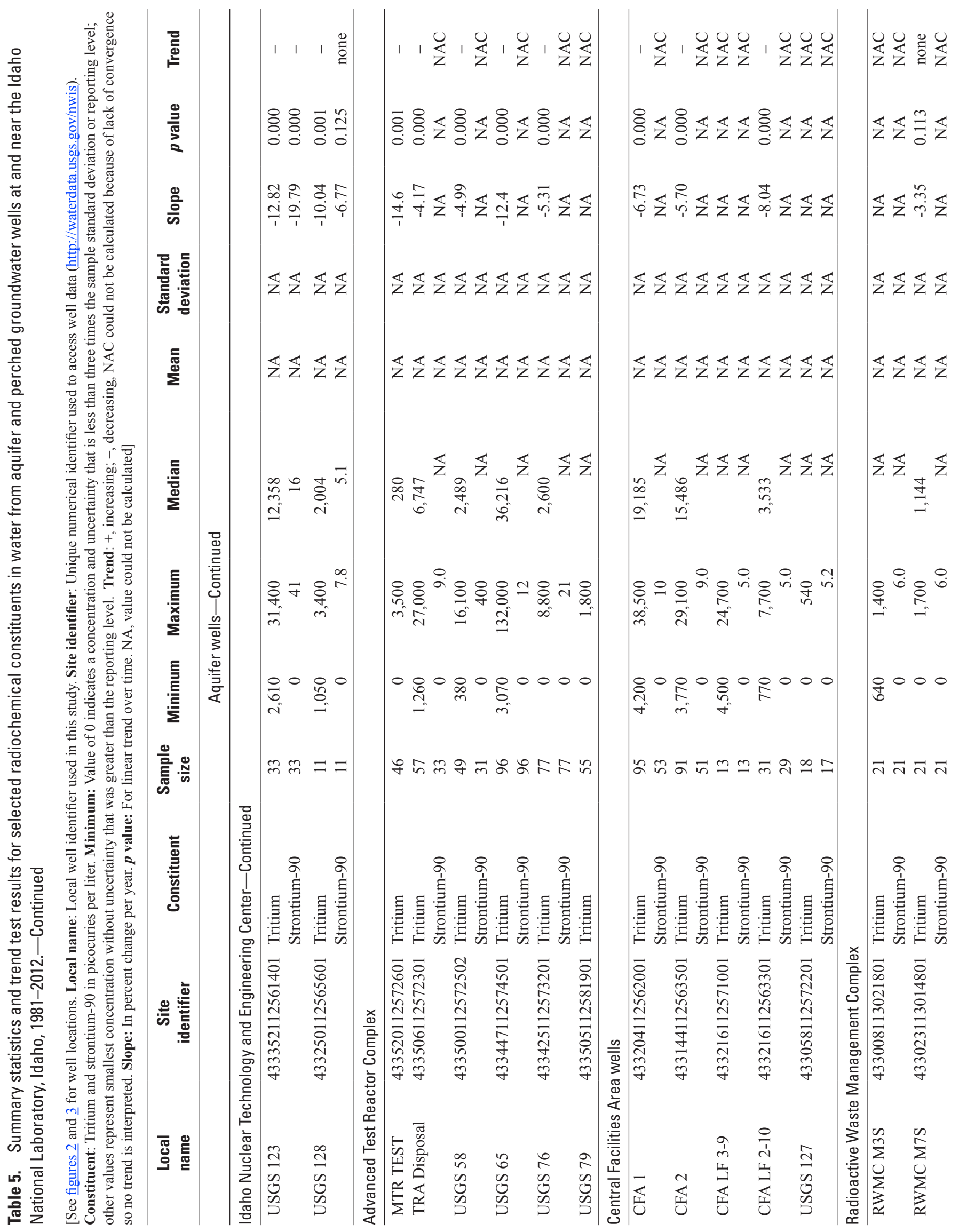




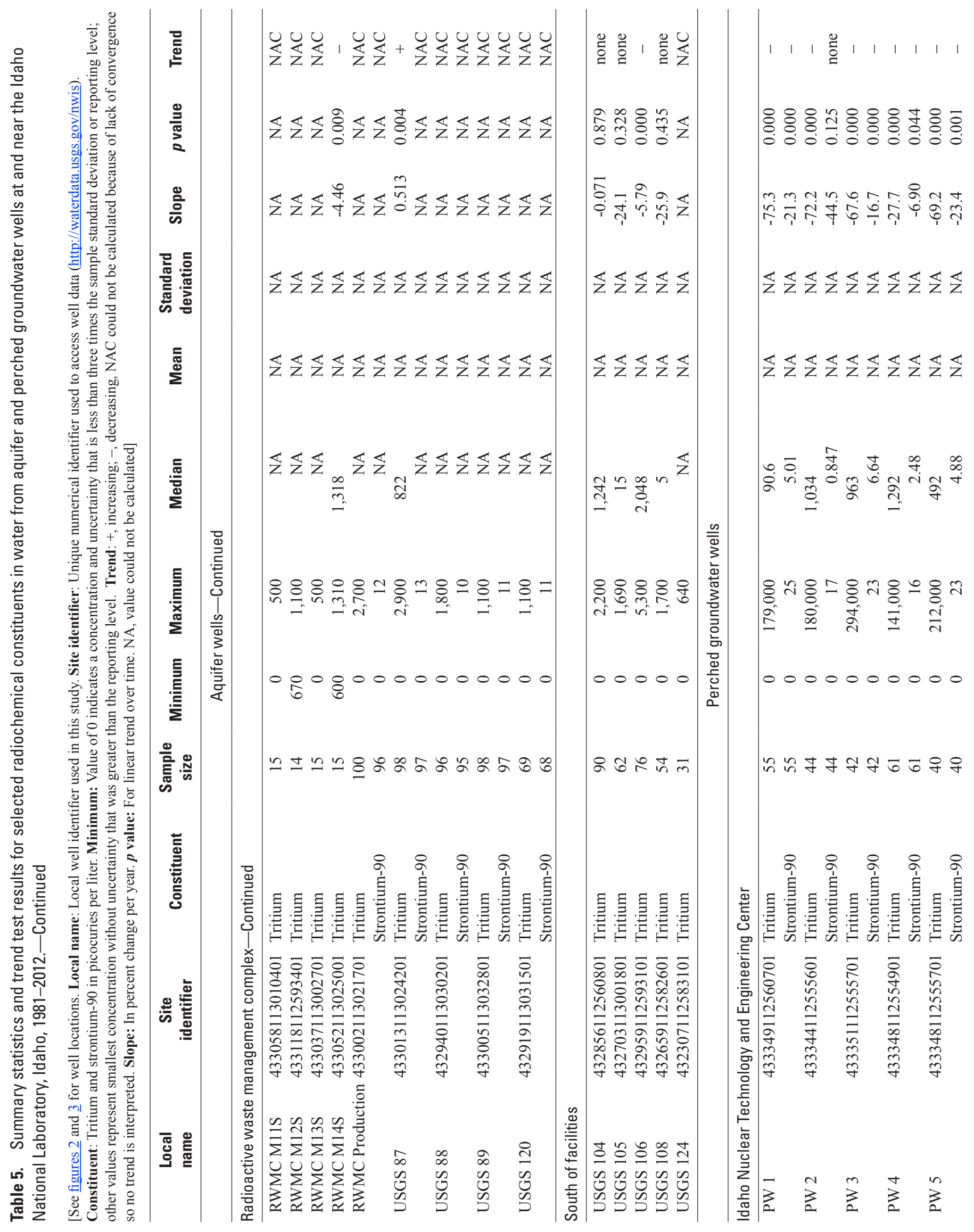




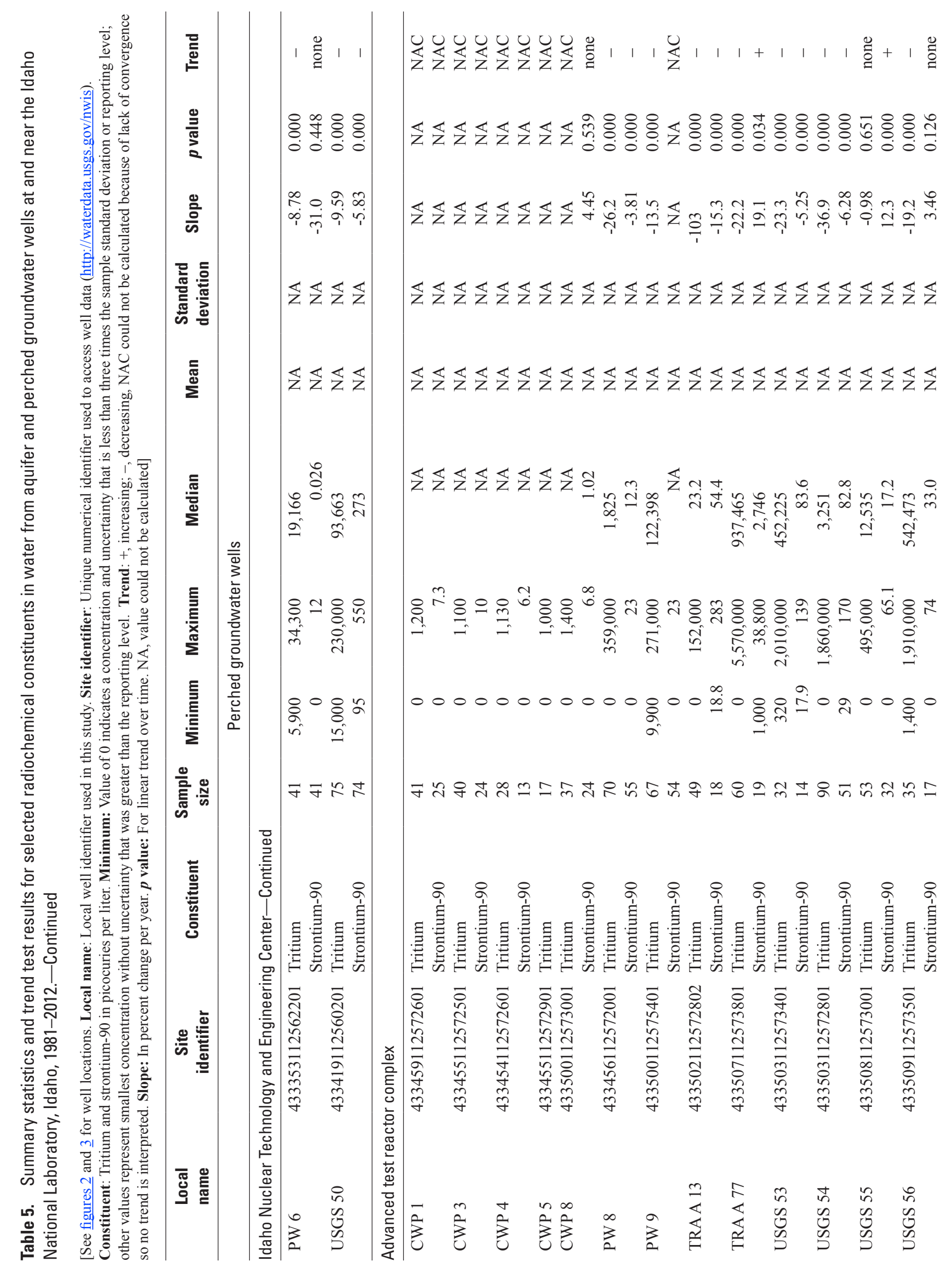




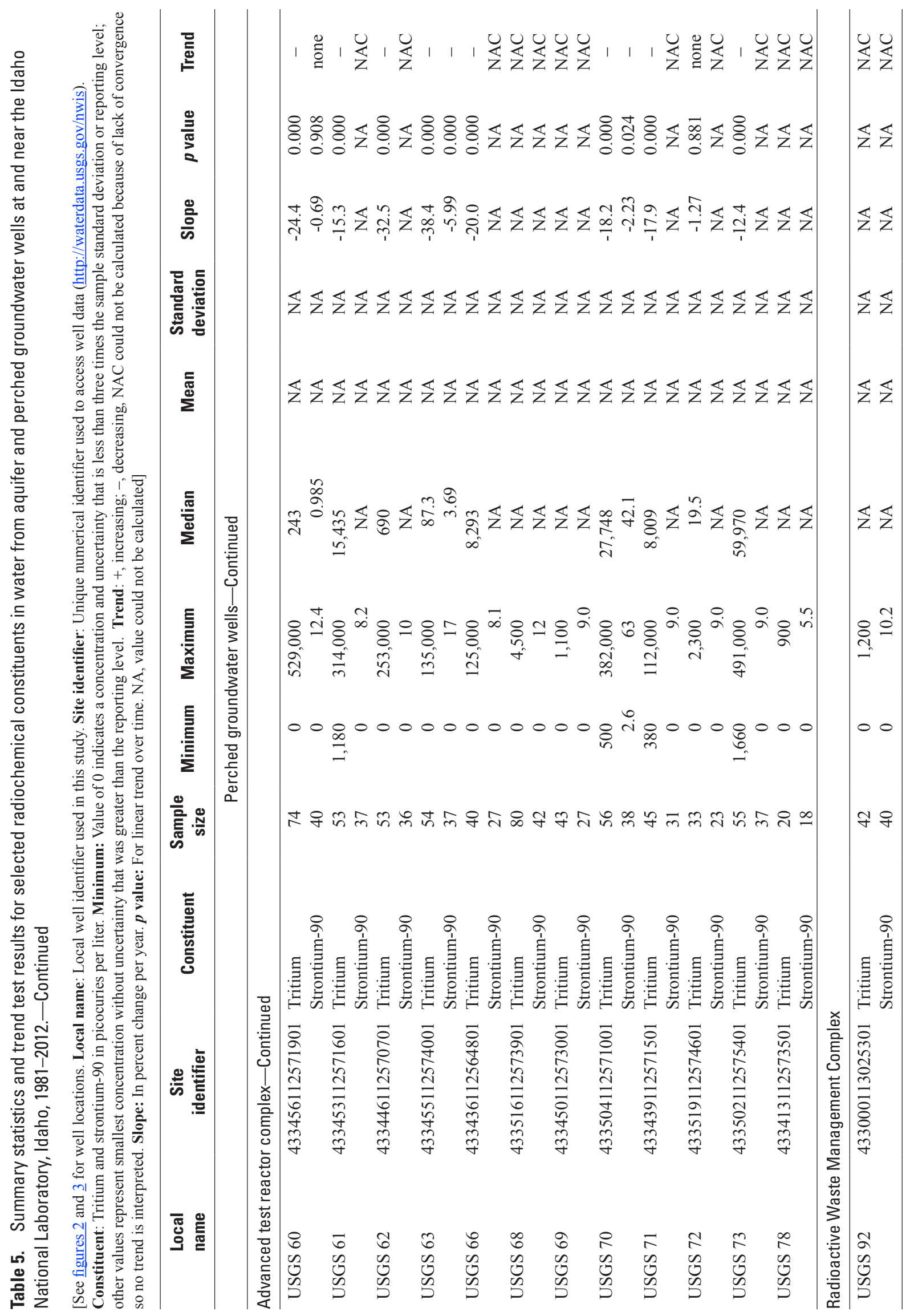


Table 6. Summary of water-quality results for selected radiochemical constituents in water from aquifer and perched groundwater wells at and near the Idaho National Laboratory, Idaho.

[See figures 2 and $\underline{3}$ for well locations. Data available at http://waterdata.usgs.gov/nwis. Local name: Local well identifier used in this study. Constituent: Concentrations in picocuries per liter. Concentration ranges: For values equal to or greater than the reporting level (three sample standard deviations) and year concentration was sampled. Uncertainty is one sample standard deviation; \pm , plus or minus; N/A, no values greater than reporting level]

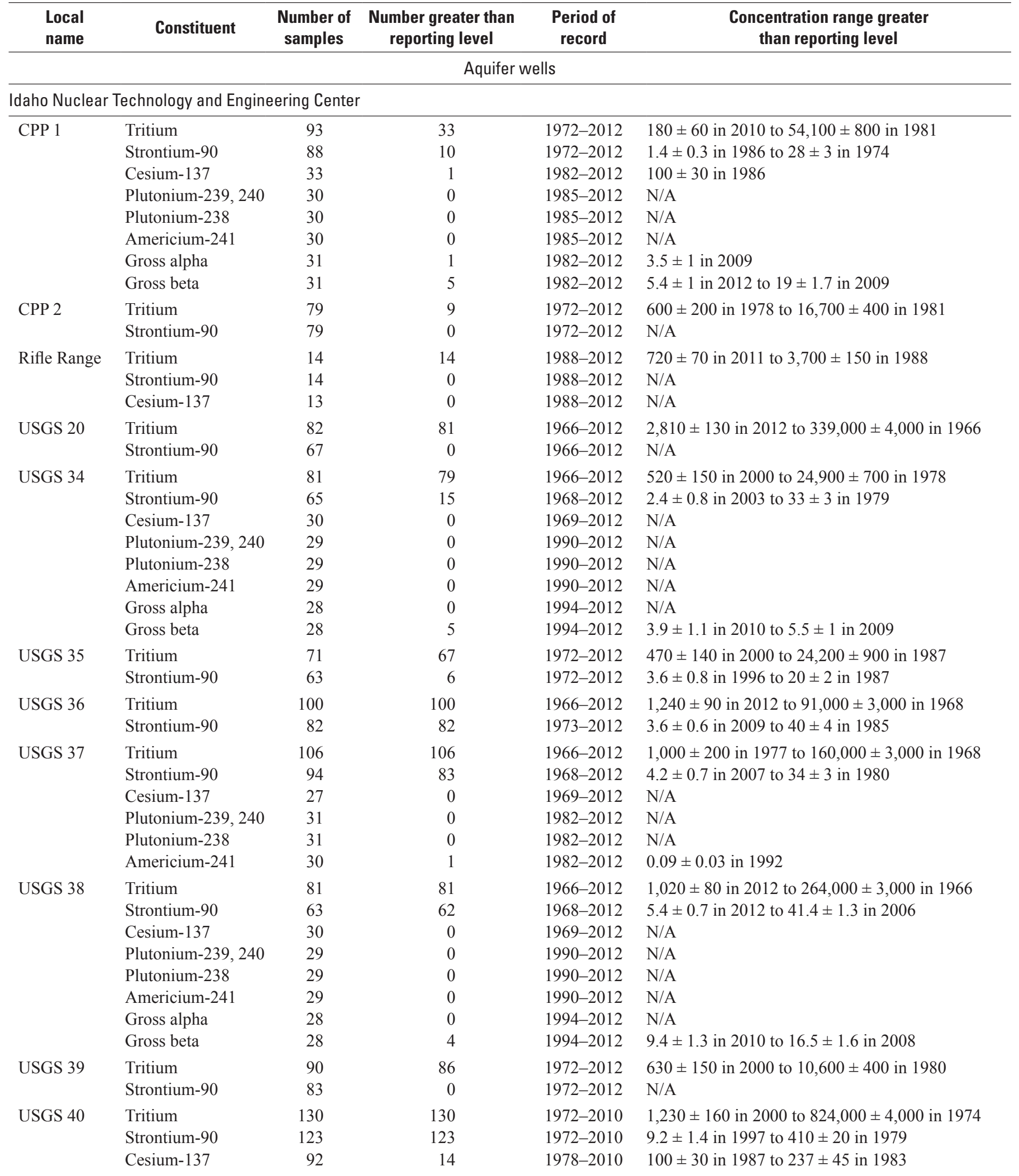


Table 6. Summary of water-quality results for selected radiochemical constituents in water from aquifer and perched groundwater wells at and near the Idaho National Laboratory, Idaho.-Continued

[See figures 2 and $\underline{3}$ for well locations. Data available at http://waterdata.usgs.gov/nwis. Local name: Local well identifier used in this study. Constituent: Concentrations in picocuries per liter. Concentration ranges: For values equal to or greater than the reporting level (three sample standard deviations) and year concentration was sampled. Uncertainty is one sample standard deviation; \pm , plus or minus; N/A, no values greater than reporting level]

\begin{tabular}{|c|c|c|c|c|c|}
\hline $\begin{array}{l}\text { Local } \\
\text { name }\end{array}$ & Constituent & $\begin{array}{l}\text { Number of } \\
\text { samples }\end{array}$ & $\begin{array}{l}\text { Number greater than } \\
\text { reporting level }\end{array}$ & $\begin{array}{l}\text { Period of } \\
\text { record }\end{array}$ & $\begin{array}{c}\text { Concentration range greater } \\
\text { than reporting level }\end{array}$ \\
\hline \multicolumn{6}{|c|}{ Aquifer wells-Continued } \\
\hline \multicolumn{6}{|c|}{ Idaho Nuclear Technology and Engineering Center-Continued } \\
\hline \multirow{3}{*}{$\begin{array}{l}\text { USGS } 40 \\
\text { - Continued }\end{array}$} & Plutonium-239, 240 & 77 & 4 & $1982-2010$ & $0.036 \pm 0.005$ in 1982 to $5.5 \pm 0.4$ in 1987 \\
\hline & Plutonium-238 & 77 & 7 & $1982-2010$ & $0.11 \pm 0.03$ in 1983 to $1.31 \pm 0.09$ in 1983 \\
\hline & Americium-241 & 67 & 1 & $1983-2010$ & $1 \pm 0.2$ in 1987 \\
\hline USGS 41 & Strontium-90 & 69 & 69 & 1972-2012 & $7.7 \pm 0.8$ in 2009 to $200 \pm 10$ in 1980 \\
\hline \multirow[t]{2}{*}{ USGS 42} & Tritium & 82 & 75 & 1972-2012 & $510 \pm 140$ in 1999 to $216,000 \pm 2,000$ in 1983 \\
\hline & Strontium-90 & 70 & 66 & 1972-2012 & $3.3 \pm 0.8$ in 1999 to $150 \pm 7$ in 1983 \\
\hline \multirow[t]{2}{*}{ USGS 43} & Tritium & 73 & 71 & 1972-2012 & $1,200 \pm 200$ in 1988 to $366,000 \pm 2,000$ in 1977 \\
\hline & Strontium-90 & 63 & 21 & 1972-2012 & $2.3 \pm 0.7$ in 2003 to $127 \pm 8$ in 1977 \\
\hline \multirow[t]{3}{*}{ USGS 44} & Tritium & 73 & 28 & 1967-2012 & $500 \pm 100$ in 1988 to $402,000 \pm 2,000$ in 1981 \\
\hline & Strontium-90 & 64 & 44 & 1972-2012 & $2.2 \pm 0.7$ in 2003 to $210 \pm 10$ in 1981 \\
\hline & Cesium-137 & 54 & 2 & 1981-2012 & $50 \pm 14$ in 2010 to $60 \pm 15$ in 1988 \\
\hline \multirow[t]{2}{*}{ USGS 45} & Tritium & 74 & 57 & 1972-2012 & $410 \pm 130$ in 1998 to $195,000 \pm 2,000$ in 1981 \\
\hline & Strontium-90 & 66 & 29 & $1972-2012$ & $2 \pm 0.6$ in 2004 to $79 \pm 5$ in 1982 \\
\hline \multirow[t]{3}{*}{ USGS 46} & Tritium & 72 & 68 & 1972-2012 & $320 \pm 70$ in 2010 to $371,000 \pm 2,000$ in 1981 \\
\hline & Strontium-90 & 63 & 58 & $1972-2012$ & $3.3 \pm 0.7$ in 2010 to $240 \pm 10$ in 1980 \\
\hline & Cesium-137 & 52 & 0 & $1981-2012$ & N/A \\
\hline \multirow[t]{2}{*}{ USGS 47} & Tritium & 116 & 116 & 1972-2012 & $520 \pm 60$ in 2011 to $301,000 \pm 3,000$ in 1981 \\
\hline & Strontium-90 & 104 & 104 & $1972-2012$ & $15 \pm 3$ in 1986 to $152 \pm 8$ in 1981 \\
\hline USGS 51 & Strontium-90 & 69 & 5 & 1972-2012 & $2.5 \pm 0.7$ in 2008 to $20 \pm 3$ in 1973 \\
\hline \multirow[t]{2}{*}{ USGS 52} & Tritium & 72 & 72 & $1972-2012$ & $760 \pm 80$ in 2012 to $245,000 \pm 2,000$ in 1978 \\
\hline & Strontium-90 & 65 & 65 & $1973-2012$ & $3.9 \pm 0.8$ in 2010 to $104 \pm 6$ in 1980 \\
\hline \multirow[t]{3}{*}{ USGS 57} & Tritium & 107 & 107 & 1972-2012 & $800 \pm 200$ in 1977 to $239,000 \pm 2,000$ in 1977 \\
\hline & Strontium-90 & 102 & 102 & 1973-2012 & $7.5 \pm 0.7$ in 1998 to $105 \pm 7$ in 1979 \\
\hline & Cesium-137 & 14 & 0 & $1997-2012$ & $\mathrm{~N} / \mathrm{A}$ \\
\hline \multirow[t]{2}{*}{ USGS 59} & Tritium & 78 & 78 & $1972-2012$ & $500 \pm 70$ in 2012 to $81,900 \pm 800$ in 1981 \\
\hline & Strontium-90 & 70 & 66 & $1972-2012$ & $6 \pm 2$ in 1974 to $39 \pm 3$ in 1981 \\
\hline \multirow[t]{2}{*}{ USGS 67} & Tritium & 67 & 67 & 1972-2012 & $3,120 \pm 140$ in 2011 to $462,000 \pm 2,000$ in 1977 \\
\hline & Strontium-90 & 60 & 59 & $1972-2012$ & $8.8 \pm 0.6$ in 2002 to $69 \pm 4$ in 1982 \\
\hline \multirow[t]{5}{*}{ USGS 77} & Tritium & 79 & 79 & 1966-2012 & $3,490 \pm 150$ in 2011 to $241,000 \pm 3,000$ in 1966 \\
\hline & Strontium-90 & 67 & 7 & 1968-2012 & $2 \pm 0.5$ in 1998 to $7 \pm 2$ in 1988 \\
\hline & Cesium-137 & 28 & 0 & 1969-2012 & $\mathrm{N} / \mathrm{A}$ \\
\hline & Plutonium-239, 240 & 27 & 0 & 1990-2012 & N/A \\
\hline & Plutonium-238 & 27 & 0 & 1990-2012 & N/A \\
\hline
\end{tabular}


Table 6. Summary of water-quality results for selected radiochemical constituents in water from aquifer and perched groundwater wells at and near the Idaho National Laboratory, Idaho.-Continued

[See figures 2 and $\underline{3}$ for well locations. Data available at http://waterdata.usgs.gov/nwis. Local name: Local well identifier used in this study. Constituent: Concentrations in picocuries per liter. Concentration ranges: For values equal to or greater than the reporting level (three sample standard deviations) and year concentration was sampled. Uncertainty is one sample standard deviation; \pm , plus or minus; N/A, no values greater than reporting level]

\begin{tabular}{|c|c|c|c|c|c|}
\hline $\begin{array}{l}\text { Local } \\
\text { name }\end{array}$ & Constituent & $\begin{array}{l}\text { Number of } \\
\text { samples }\end{array}$ & $\begin{array}{l}\text { Number greater than } \\
\text { reporting level }\end{array}$ & $\begin{array}{l}\text { Period of } \\
\text { record }\end{array}$ & $\begin{array}{l}\text { Concentration range greater } \\
\text { than reporting level }\end{array}$ \\
\hline \multicolumn{6}{|c|}{ Aquifer wells-Continued } \\
\hline USGS 77 & Americium-241 & 27 & 0 & 1990-2012 & $\mathrm{N} / \mathrm{A}$ \\
\hline -Continued & $\begin{array}{l}\text { Gross alpha } \\
\text { Gross beta }\end{array}$ & $\begin{array}{l}24 \\
24\end{array}$ & $\begin{array}{l}1 \\
5\end{array}$ & $\begin{array}{l}1995-2012 \\
1995-2012\end{array}$ & $\begin{array}{l}4 \pm 1 \text { in } 2008 \\
8.4 \pm 1 \text { in } 2009 \text { to } 14.6 \pm 1.4 \text { in } 2008\end{array}$ \\
\hline USGS 84 & $\begin{array}{l}\text { Tritium } \\
\text { Strontium-90 } \\
\text { Cesium-137 } \\
\text { Plutonium-239, } 240 \\
\text { Plutonium-238 } \\
\text { Americium-241 } \\
\text { Gross alpha } \\
\text { Gross beta }\end{array}$ & $\begin{array}{l}69 \\
26 \\
28 \\
28 \\
28 \\
28 \\
28 \\
28\end{array}$ & $\begin{array}{r}66 \\
0 \\
0 \\
0 \\
0 \\
0 \\
1 \\
12\end{array}$ & $\begin{array}{l}1972-2012 \\
1994-2012 \\
1981-2012 \\
1994-2012 \\
1994-2012 \\
1994-2012 \\
1994-2012 \\
1994-2012\end{array}$ & $\begin{array}{l}540 \pm 60 \text { in } 2011 \text { to } 12,000 \pm 2,000 \text { in } 1973 \\
\text { N/A } \\
\text { N/A } \\
\text { N/A } \\
\text { N/A } \\
\text { N/A } \\
4.2 \pm 1 \text { in } 2008 \\
2.4 \pm 0.8 \text { in } 2012 \text { to } 4.4 \pm 0.59 \text { in } 2001\end{array}$ \\
\hline USGS 85 & $\begin{array}{l}\text { Tritium } \\
\text { Strontium-90 }\end{array}$ & $\begin{array}{l}81 \\
68\end{array}$ & $\begin{array}{l}81 \\
29\end{array}$ & $\begin{array}{l}1966-2012 \\
1968-2012\end{array}$ & $\begin{array}{l}1,520 \pm 100 \text { in } 2012 \text { to } 55,900 \pm 900 \text { in } 1978 \\
2.1 \pm 0.6 \text { in } 1998 \text { to } 9 \pm 3 \text { in } 1977\end{array}$ \\
\hline USGS 111 & $\begin{array}{l}\text { Tritium } \\
\text { Strontium-90 }\end{array}$ & $\begin{array}{l}56 \\
56\end{array}$ & $\begin{array}{r}56 \\
2\end{array}$ & $\begin{array}{l}1985-2012 \\
1985-2012\end{array}$ & $\begin{array}{l}2,700 \pm 130 \text { in } 2012 \text { to } 164,000 \pm 5,000 \text { in } 1986 \\
11 \pm 2 \text { in } 1987 \text { to } 28 \pm 3 \text { in } 1989\end{array}$ \\
\hline USGS 112 & $\begin{array}{l}\text { Tritium } \\
\text { Strontium-90 }\end{array}$ & $\begin{array}{l}76 \\
76\end{array}$ & $\begin{array}{l}76 \\
76\end{array}$ & $\begin{array}{l}1985-2012 \\
1985-2012\end{array}$ & $\begin{array}{l}1,010 \pm 80 \text { in } 2012 \text { to } 88,200 \pm 2,500 \text { in } 1986 \\
8.6 \pm 0.8 \text { in } 2006 \text { to } 53 \pm 4 \text { in } 1987\end{array}$ \\
\hline USGS 113 & $\begin{array}{l}\text { Tritium } \\
\text { Strontium-90 } \\
\text { Cesium-137 }\end{array}$ & $\begin{array}{l}74 \\
73 \\
16\end{array}$ & $\begin{array}{r}74 \\
72 \\
0\end{array}$ & $\begin{array}{l}1985-2012 \\
1985-2012 \\
1994-2012\end{array}$ & $\begin{array}{l}2,050 \pm 110 \text { in } 2012 \text { to } 108,000 \pm 4,000 \text { in } 1986 \\
5.9 \pm 0.8 \text { in } 2010 \text { to } 30 \pm 3 \text { in } 1986 \\
\text { N/A }\end{array}$ \\
\hline USGS 114 & $\begin{array}{l}\text { Tritium } \\
\text { Strontium-90 }\end{array}$ & $\begin{array}{l}74 \\
74\end{array}$ & $\begin{array}{r}74 \\
2\end{array}$ & $\begin{array}{l}1985-2012 \\
1985-2012\end{array}$ & $\begin{array}{l}7,020 \pm 260 \text { in } 2011 \text { to } 37,700 \pm 1,200 \text { in } 1986 \\
2.1 \pm 0.6 \text { in } 2003 \text { to } 8 \pm 2 \text { in } 1987\end{array}$ \\
\hline USGS 128 & $\begin{array}{l}\text { Tritium } \\
\text { Strontium-90 }\end{array}$ & $\begin{array}{l}11 \\
11\end{array}$ & $\begin{array}{l}11 \\
11\end{array}$ & $\begin{array}{l}2001-2012 \\
2001-2012 \\
\end{array}$ & $\begin{array}{l}1,290 \pm 80 \text { in } 2012 \text { to } 4,300 \pm 300 \text { in } 2001 \\
3.5 \pm 0.7 \text { in } 2011 \text { to } 9.6 \pm 0.8 \text { in } 2004\end{array}$ \\
\hline Advanced Test $\mathrm{F}$ & Reactor Complex & & & & \\
\hline MTR Test & Tritium & 58 & 21 & $1972-2012$ & $420 \pm 140$ in 2007 to $4,400 \pm 300$ in 1991 \\
\hline TRA Disposal & $\begin{array}{l}\text { Tritium } \\
\text { Strontium-90 } \\
\text { Cesium-137 }\end{array}$ & $\begin{array}{l}57 \\
33 \\
50\end{array}$ & $\begin{array}{r}57 \\
1 \\
0\end{array}$ & $\begin{array}{l}1985-2012 \\
1987-2012 \\
1986-2012\end{array}$ & $\begin{array}{l}1,530 \pm 90 \text { in } 2011 \text { to } 29,100 \pm 700 \text { in } 1992 \\
4.1 \pm 0.9 \text { in } 2004 \\
\text { N/A }\end{array}$ \\
\hline USGS 58 & $\begin{array}{l}\text { Tritium } \\
\text { Strontium-90 } \\
\text { Cesium-137 }\end{array}$ & $\begin{array}{l}87 \\
40 \\
37\end{array}$ & $\begin{array}{r}82 \\
1 \\
0\end{array}$ & $\begin{array}{l}1962-2012 \\
1969-2012 \\
1969-2012\end{array}$ & $\begin{array}{l}590 \pm 70 \text { in } 2012 \text { to } 140,000 \pm 20,000 \text { in } 1967 \\
155 \pm 8 \text { in } 1980 \\
\text { N/A }\end{array}$ \\
\hline USGS 65 & $\begin{array}{l}\text { Tritium } \\
\text { Strontium-90 } \\
\text { Cesium-137 } \\
\text { Plutonium-239, } 240 \\
\text { Plutonium-238 }\end{array}$ & $\begin{array}{r}133 \\
119 \\
89 \\
31 \\
32\end{array}$ & $\begin{array}{r}133 \\
4 \\
1 \\
0 \\
0\end{array}$ & $\begin{array}{l}1969-2012 \\
1972-2012 \\
1981-2012 \\
1982-2012 \\
1982-2012\end{array}$ & $\begin{array}{l}3,550 \pm 160 \text { in } 2012 \text { to } 206,000 \pm 3,000 \text { in } 1972 \\
2.1 \pm 0.7 \text { in } 2000 \text { to } 18 \pm 3 \text { in } 1976 \\
120 \pm 20 \text { in } 1988 \\
\text { N/A } \\
\text { N/A }\end{array}$ \\
\hline
\end{tabular}


Table 6. Summary of water-quality results for selected radiochemical constituents in water from aquifer and perched groundwater wells at and near the Idaho National Laboratory, Idaho.-Continued

[See figures 2 and $\underline{3}$ for well locations. Data available at http://waterdata.usgs.gov/nwis. Local name: Local well identifier used in this study. Constituent: Concentrations in picocuries per liter. Concentration ranges: For values equal to or greater than the reporting level (three sample standard deviations) and year concentration was sampled. Uncertainty is one sample standard deviation; \pm , plus or minus; N/A, no values greater than reporting level]

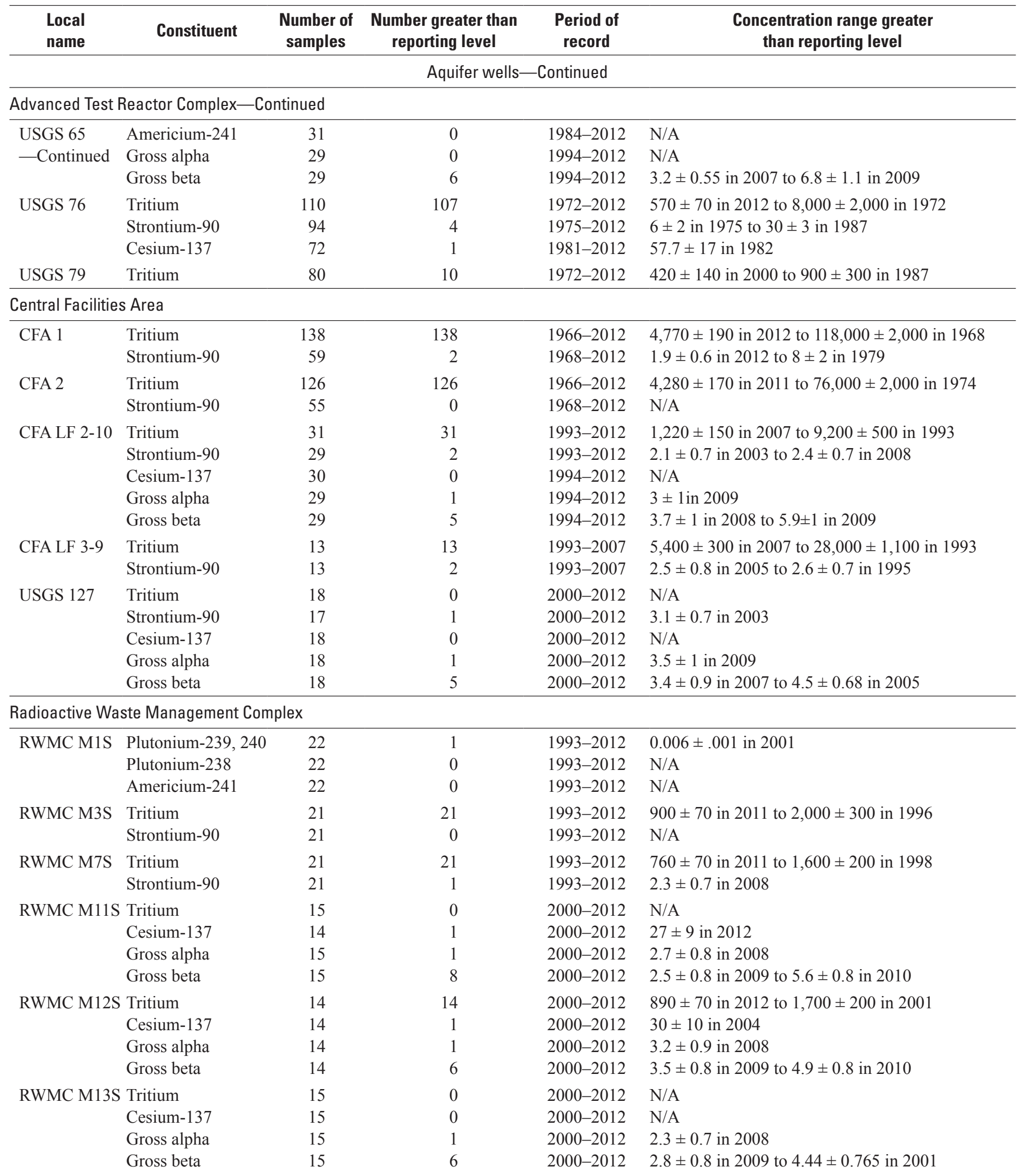


Table 6. Summary of water-quality results for selected radiochemical constituents in water from aquifer and perched groundwater wells at and near the Idaho National Laboratory, Idaho.-Continued

[See figures 2 and $\underline{3}$ for well locations. Data available at http://waterdata.usgs.gov/nwis. Local name: Local well identifier used in this study. Constituent: Concentrations in picocuries per liter. Concentration ranges: For values equal to or greater than the reporting level (three sample standard deviations) and year concentration was sampled. Uncertainty is one sample standard deviation; \pm , plus or minus; N/A, no values greater than reporting level]

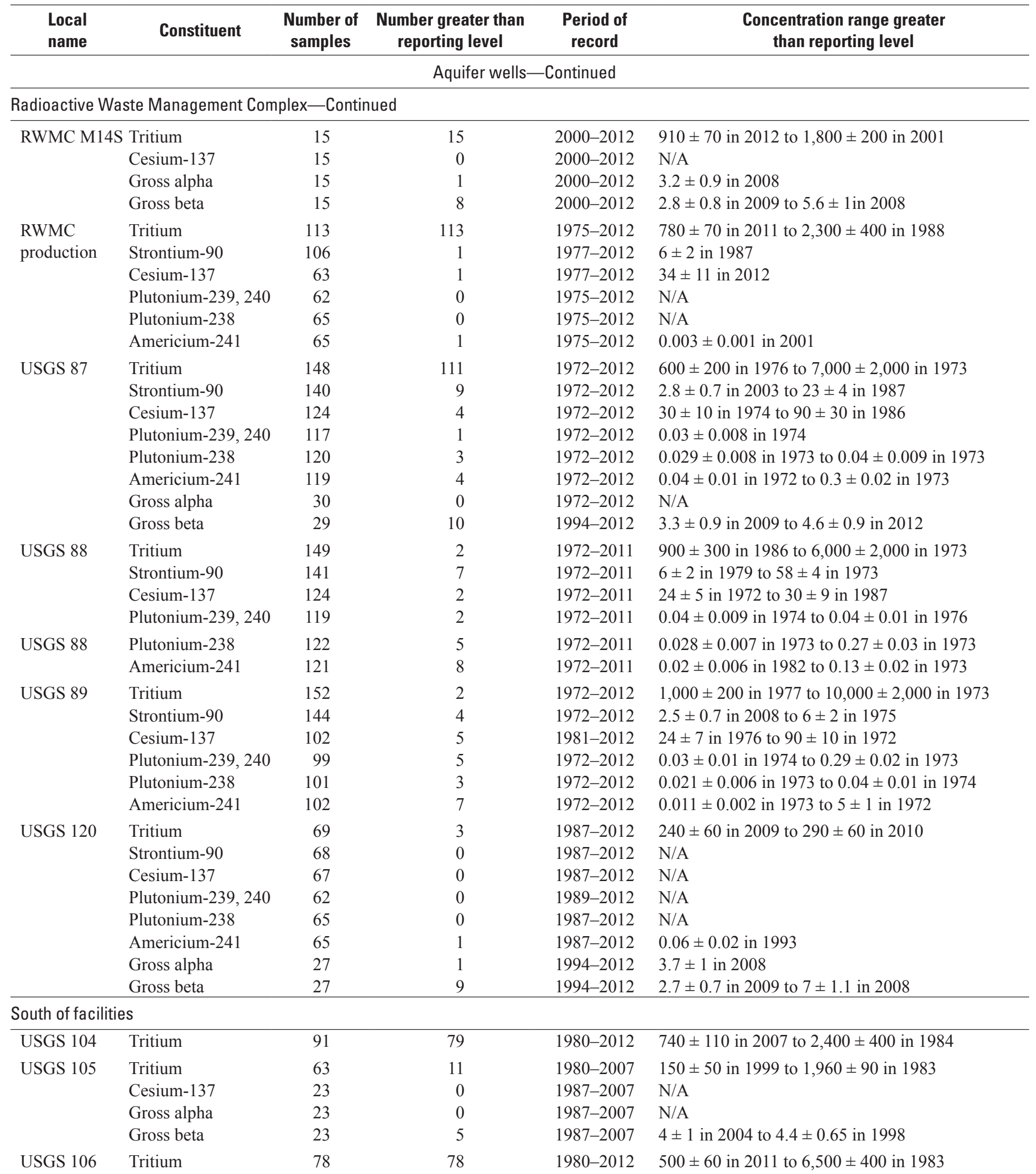


Table 6. Summary of water-quality results for selected radiochemical constituents in water from aquifer and perched groundwater wells at and near the Idaho National Laboratory, Idaho.-Continued

[See figures 2 and $\underline{3}$ for well locations. Data available at http://waterdata.usgs.gov/nwis. Local name: Local well identifier used in this study. Constituent: Concentrations in picocuries per liter. Concentration ranges: For values equal to or greater than the reporting level (three sample standard deviations) and year concentration was sampled. Uncertainty is one sample standard deviation; \pm , plus or minus; N/A, no values greater than reporting level]

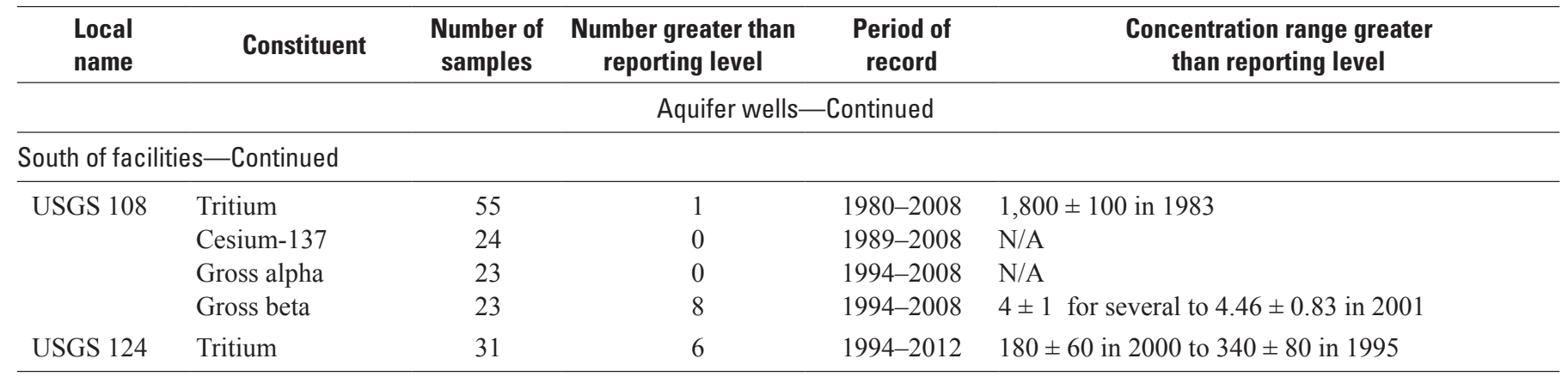

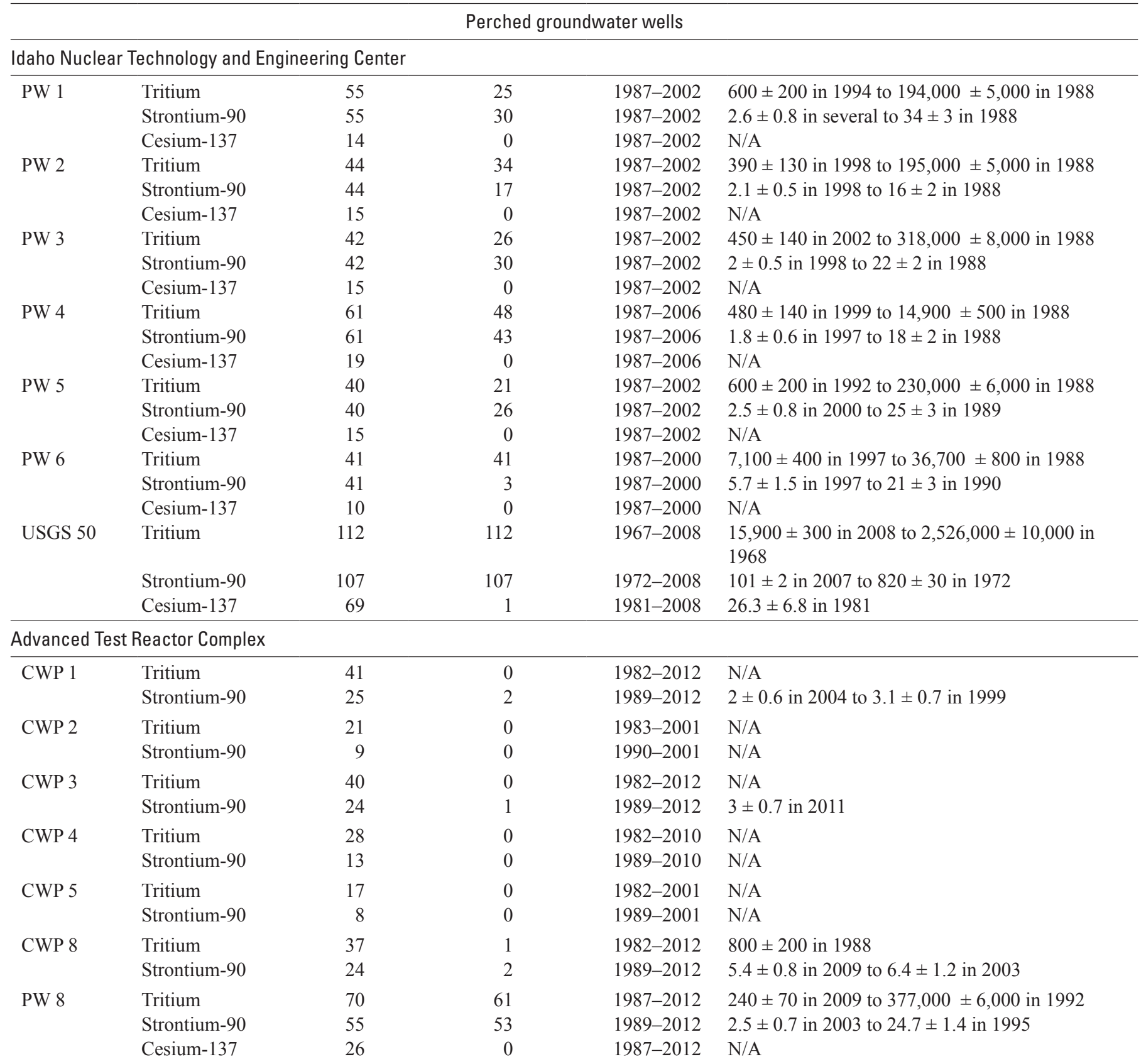


Table 6. Summary of water-quality results for selected radiochemical constituents in water from aquifer and perched groundwater wells at and near the Idaho National Laboratory, Idaho.-Continued

[See figures 2 and $\underline{3}$ for well locations. Data available at http://waterdata.usgs.gov/nwis. Local name: Local well identifier used in this study. Constituent: Concentrations in picocuries per liter. Concentration ranges: For values equal to or greater than the reporting level (three sample standard deviations) and year concentration was sampled. Uncertainty is one sample standard deviation; \pm , plus or minus; N/A, no values greater than reporting level]

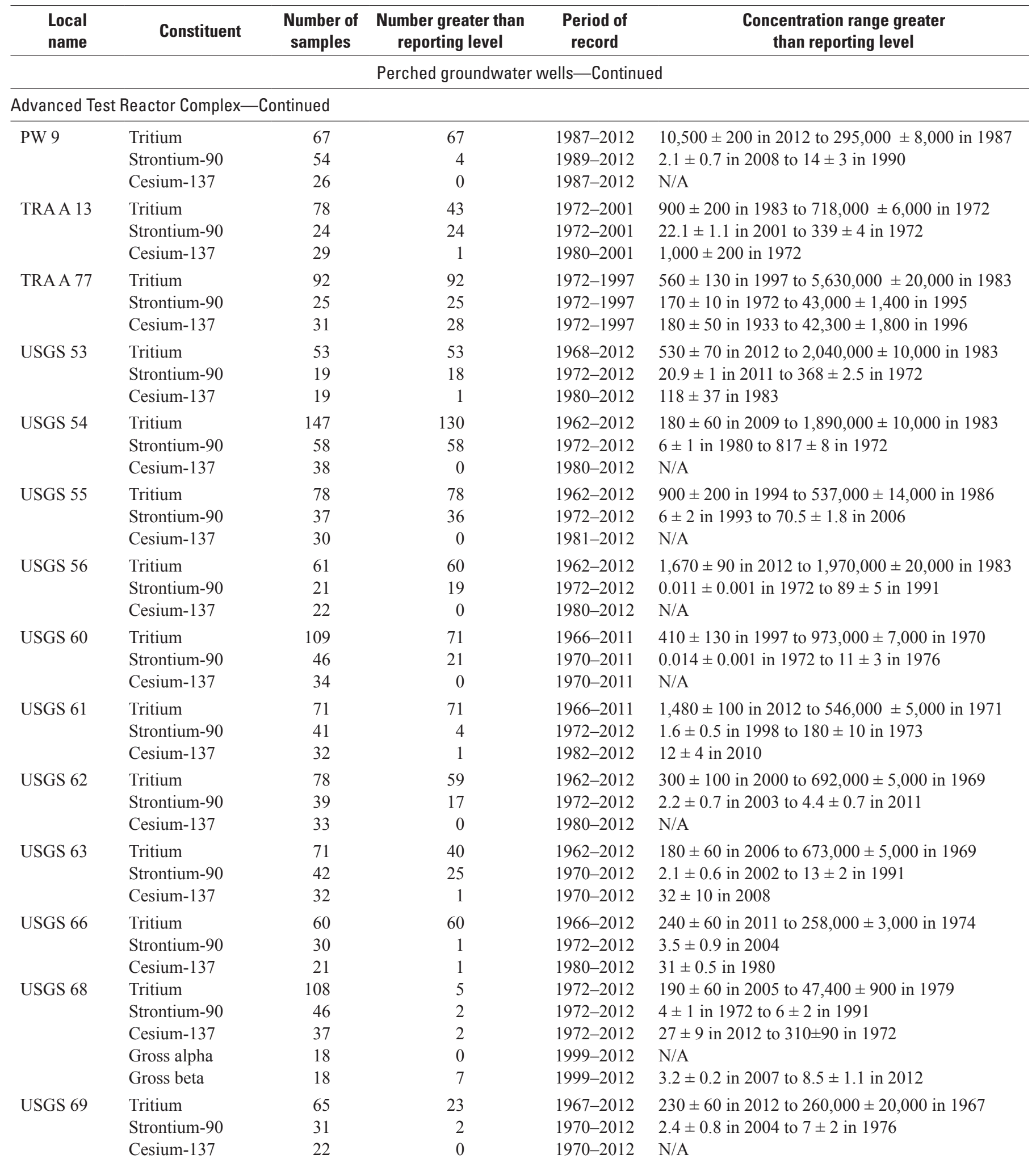


Table 6. Summary of water-quality results for selected radiochemical constituents in water from aquifer and perched groundwater wells at and near the Idaho National Laboratory, Idaho.-Continued

[See figures 2 and $\underline{3}$ for well locations. Data available at http://waterdata.usgs.gov/nwis. Local name: Local well identifier used in this study. Constituent: Concentrations in picocuries per liter. Concentration ranges: For values equal to or greater than the reporting level (three sample standard deviations) and year concentration was sampled. Uncertainty is one sample standard deviation; \pm , plus or minus; N/A, no values greater than reporting level]

\begin{tabular}{|c|c|c|c|c|c|}
\hline $\begin{array}{l}\text { Local } \\
\text { name }\end{array}$ & Constituent & $\begin{array}{l}\text { Number of } \\
\text { samples }\end{array}$ & $\begin{array}{c}\text { Number greater than } \\
\text { reporting level }\end{array}$ & $\begin{array}{l}\text { Period of } \\
\text { record }\end{array}$ & $\begin{array}{c}\text { Concentration range greater } \\
\text { than reporting level }\end{array}$ \\
\hline \multicolumn{6}{|c|}{ Perched groundwater wells - Continued } \\
\hline \multirow{2}{*}{ USGS 70} & Tritium & 84 & 84 & $1962-2012$ & $710 \pm 70$ in 2011 to $900,000 \pm 6,000$ in 1970 \\
\hline & Strontium-90 & 41 & 41 & $1972-2012$ & $5 \pm 0.8$ in 2006 to $78 \pm 5$ in 1989 \\
\hline \multirow{2}{*}{ USGS 71} & Strontium-90 & 34 & 1 & 1970-2012 & $3.7 \pm 0.8$ in 2004 \\
\hline & Cesium-137 & 27 & 0 & 1970-2012 & N/A \\
\hline \multirow[t]{3}{*}{ USGS 72} & Tritium & 37 & 3 & 1974-2012 & $450 \pm 70$ in 2012 to $2,900 \pm 200$ in 1989 \\
\hline & Strontium-90 & 26 & 1 & $1974-2012$ & $17 \pm 3$ in 1974 \\
\hline & Cesium-137 & 21 & 0 & 1984-2012 & N/A \\
\hline USGS 73 & Cesium-137 & 35 & 0 & $1970-2012$ & N/A \\
\hline \multirow[t]{3}{*}{ USGS 78} & Tritium & 24 & 0 & $1972-2012$ & $\mathrm{~N} / \mathrm{A}$ \\
\hline & Strontium-90 & 19 & 2 & $1972-2012$ & $2.6 \pm 0.7$ in 2008 to $3.1 \pm 0.8$ in 2004 \\
\hline & Cesium-137 & 11 & 0 & $1986-2012$ & N/A \\
\hline \multicolumn{6}{|c|}{ Radioactive Waste Management Complex } \\
\hline \multirow[t]{5}{*}{$\overline{\text { USGS } 92}$} & Tritium & 49 & 10 & 1972-2012 & $300 \pm 100$ in 2000 to $580 \pm 70$ in 2012 \\
\hline & Strontium-90 & 47 & 2 & $1972-2012$ & $7.2 \pm 1$ in 1998 to $9 \pm 2$ in 1980 \\
\hline & Cesium-137 & 48 & 3 & $1972-2012$ & $60 \pm 10$ in 1972 to $200 \pm 10$ in 1972 \\
\hline & Plutonium-239, 240 & 43 & 0 & $1972-2012$ & N/A \\
\hline & Plutonium-238 & 47 & 2 & $1972-2012$ & $0.025 \pm 0.008$ in 1974 to $0.39 \pm 0.05$ in 1994 \\
\hline
\end{tabular}



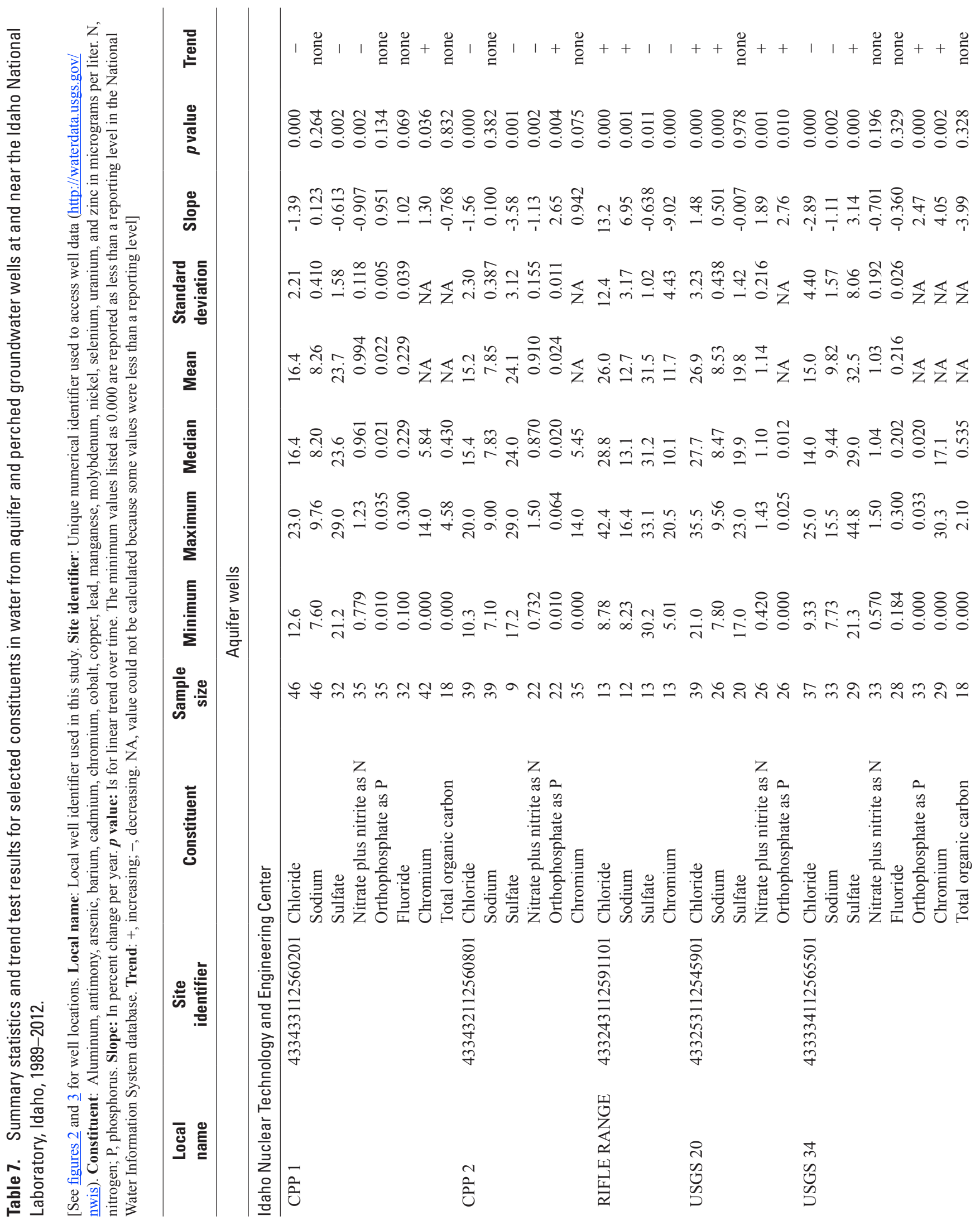

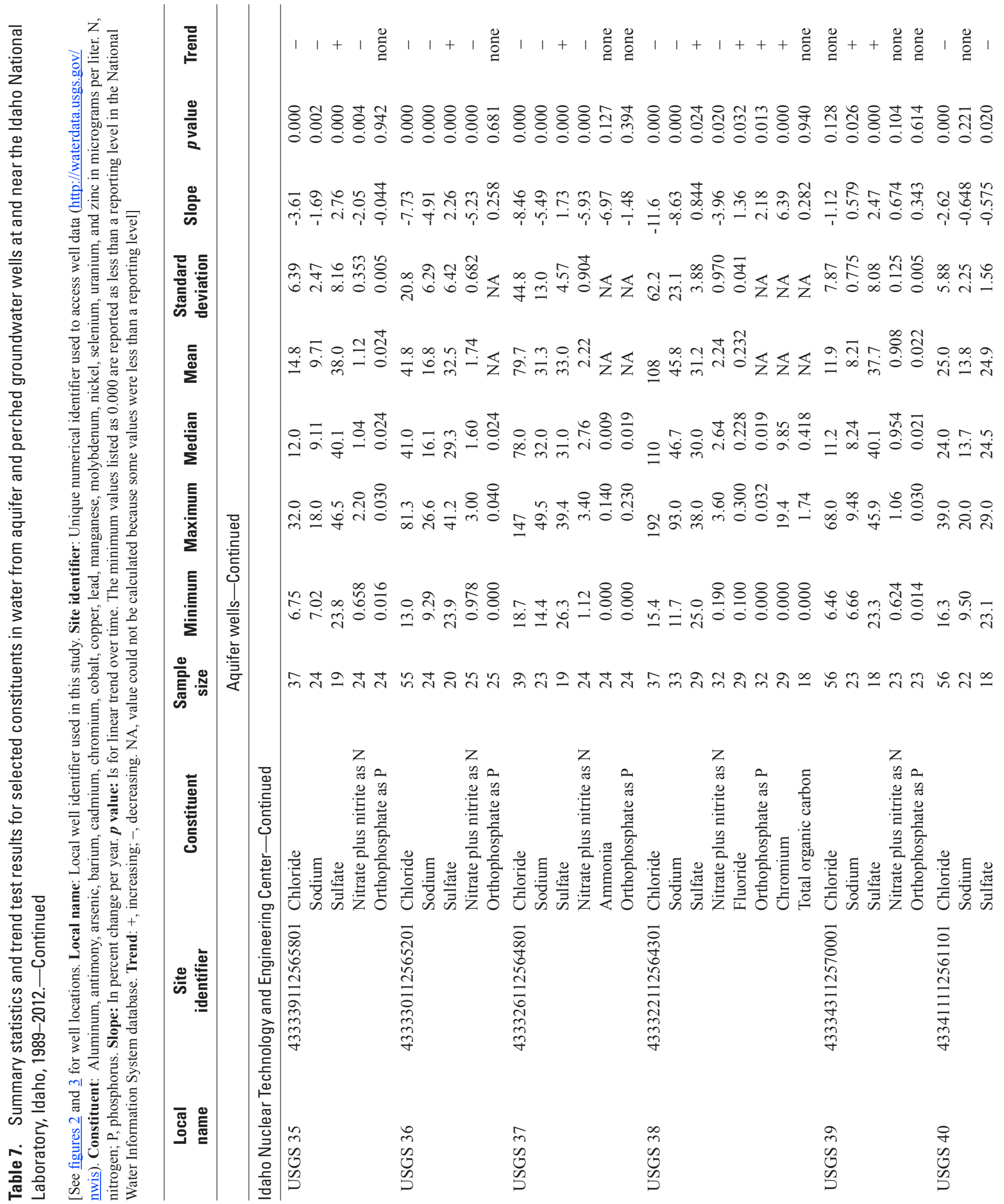

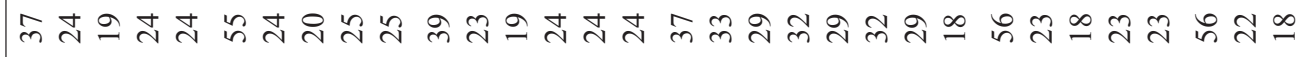

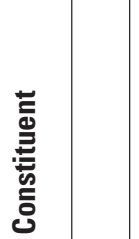

z

究 0

of

莺

$\stackrel{5}{\frac{2}{2}}$

z

帘o

.

莺

$z$

응

का के के

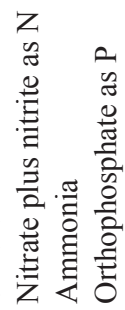

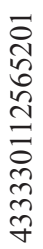

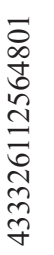

0
n
0
0
0

$n$
n
ñ
0

$\infty$
$\infty$
0
0
0

ले
Dू
D

Z

\& 2

造

青

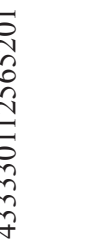

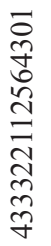

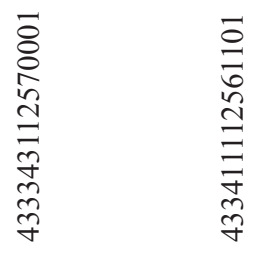

妾 


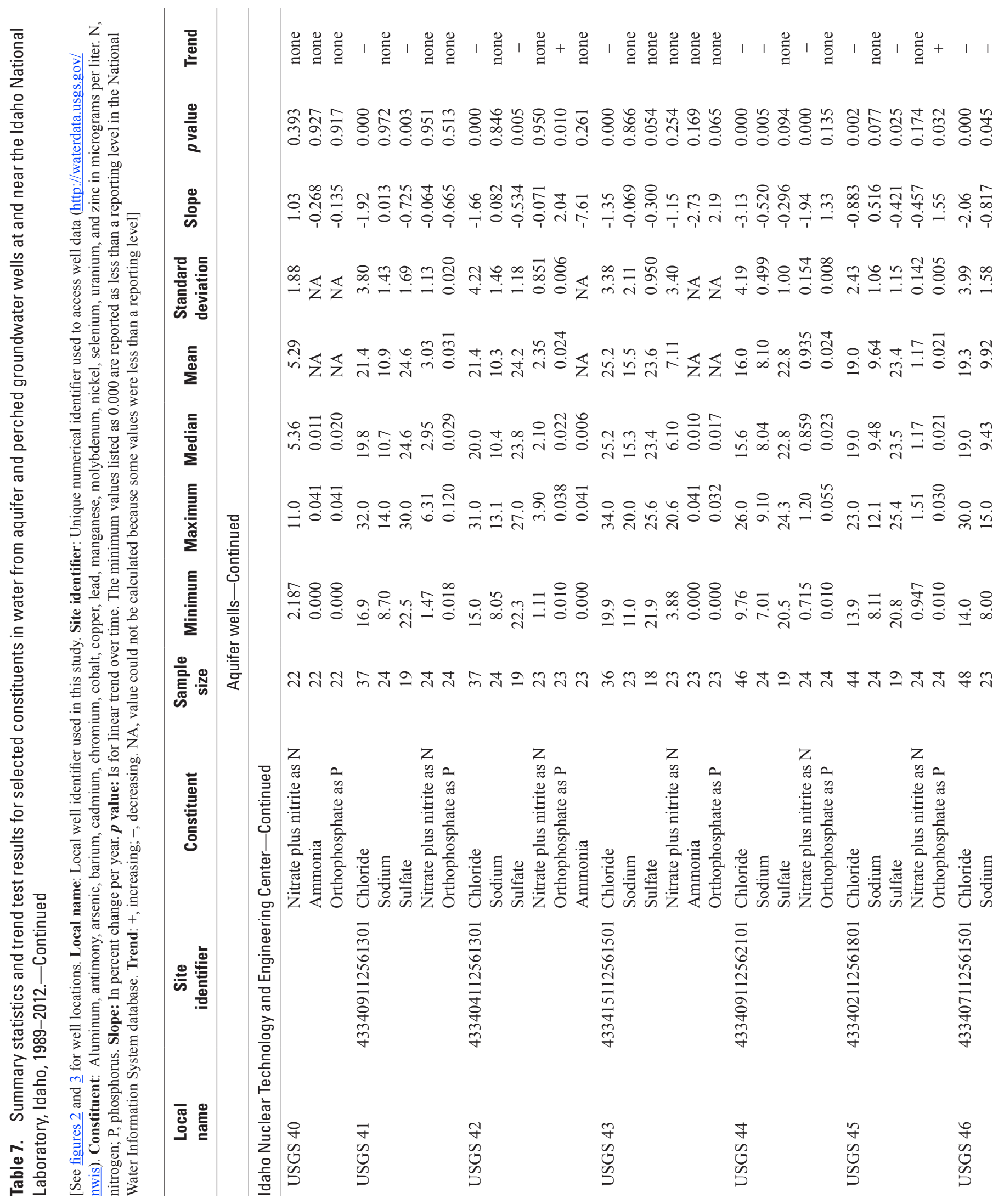



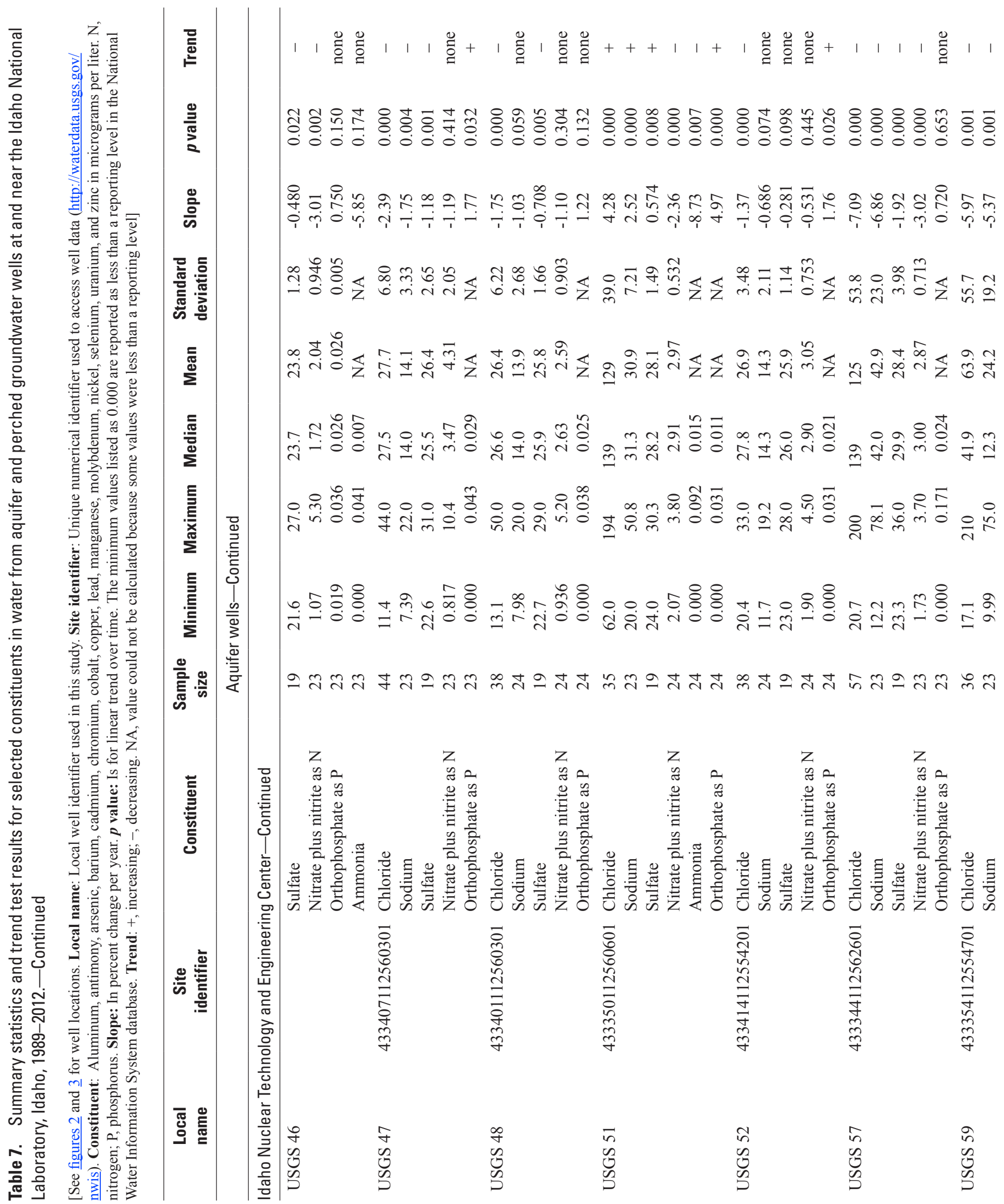


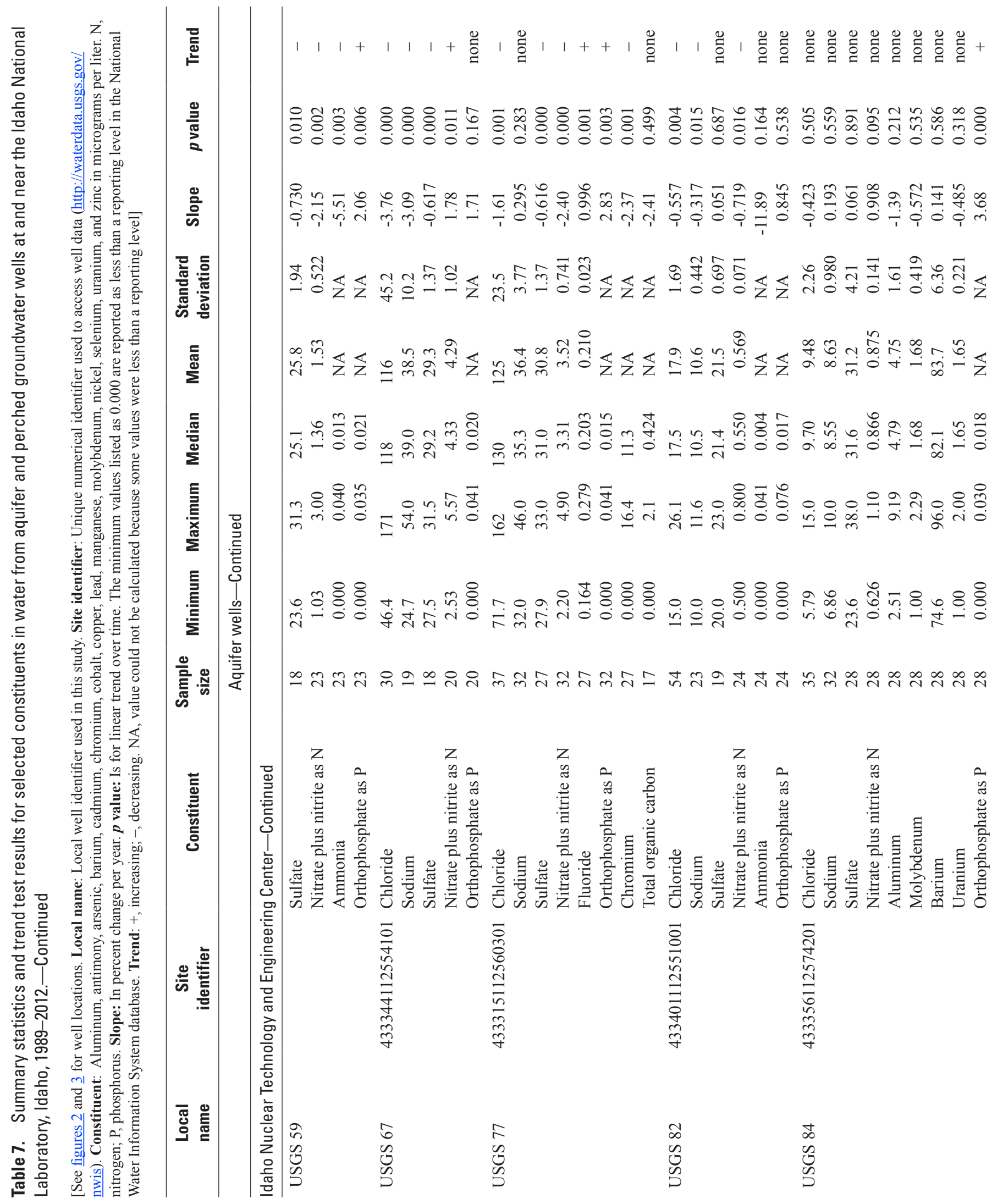



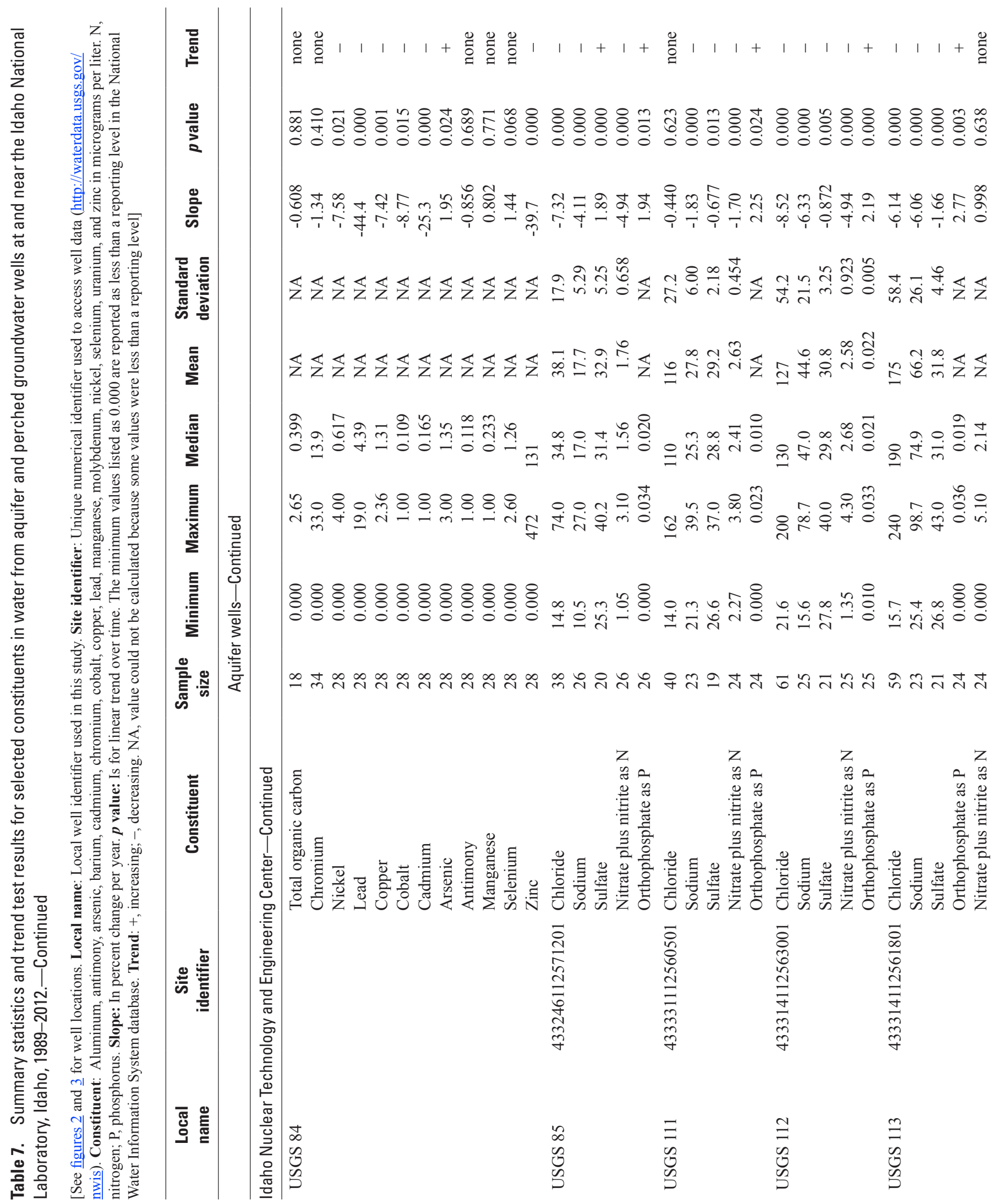
Table 7

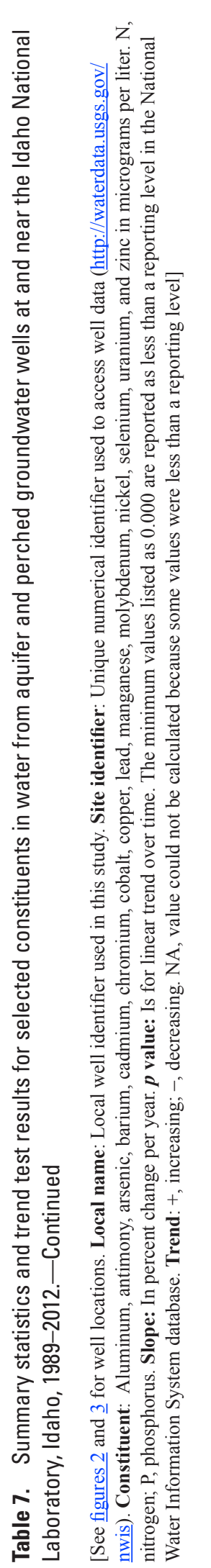

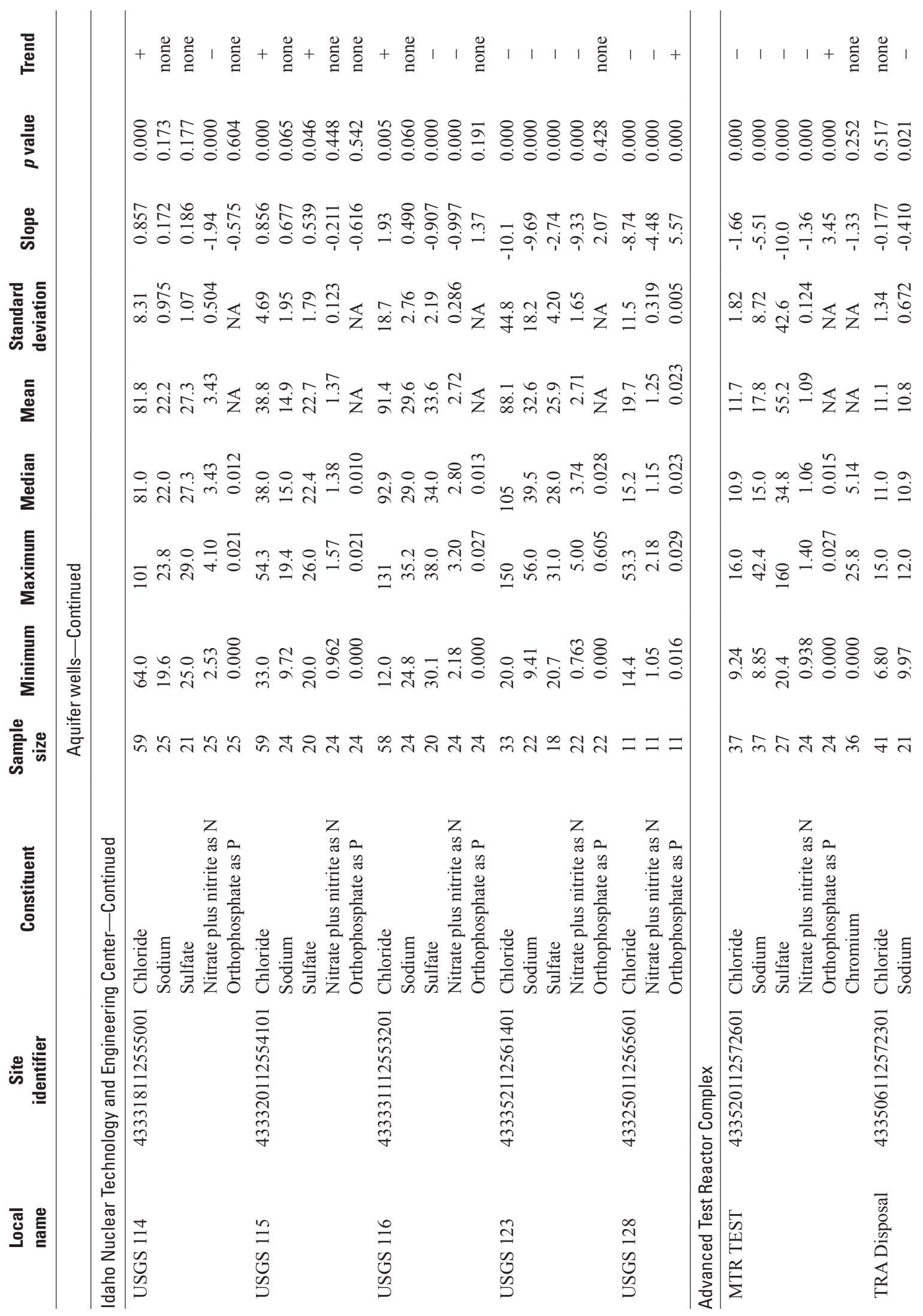




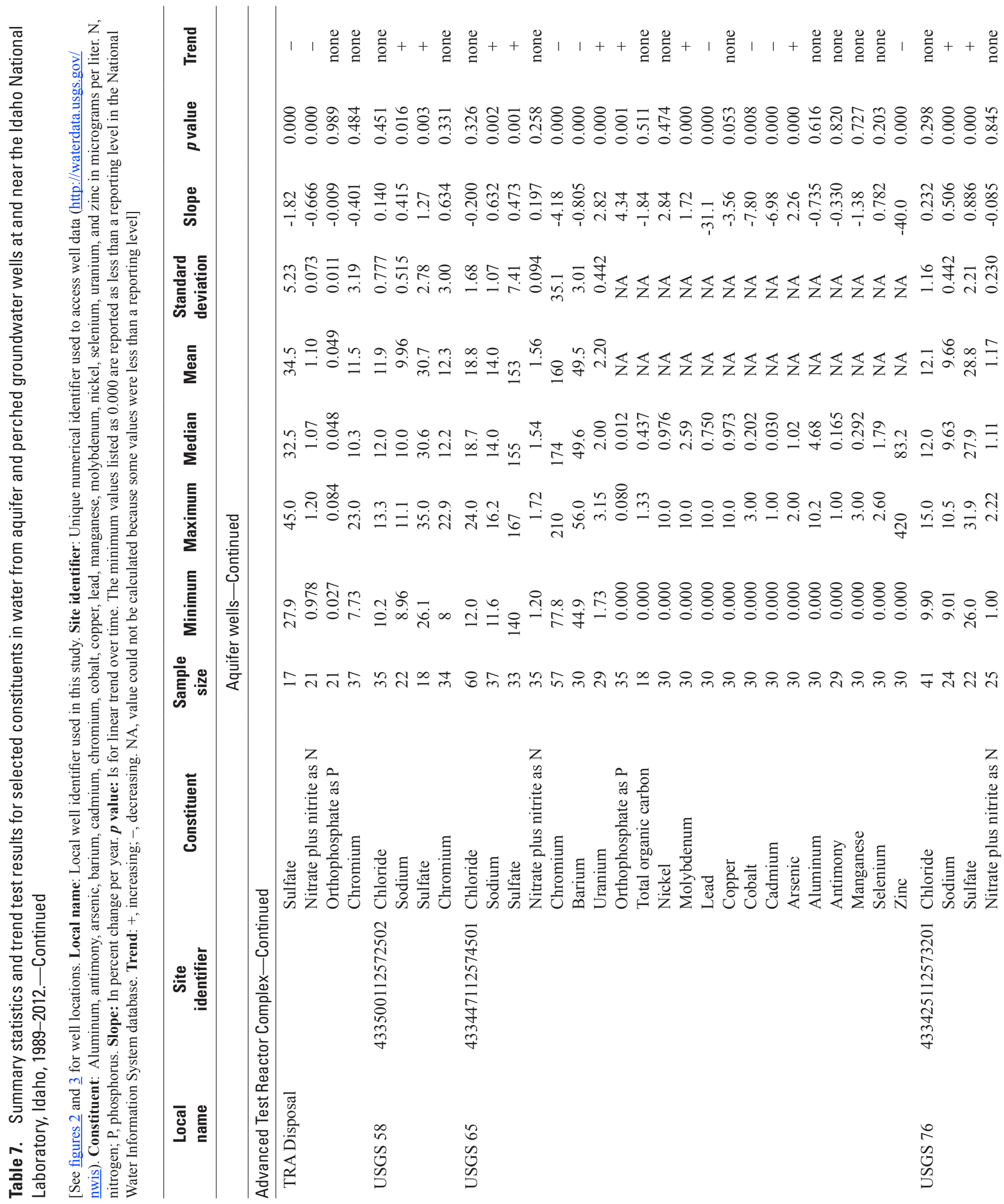




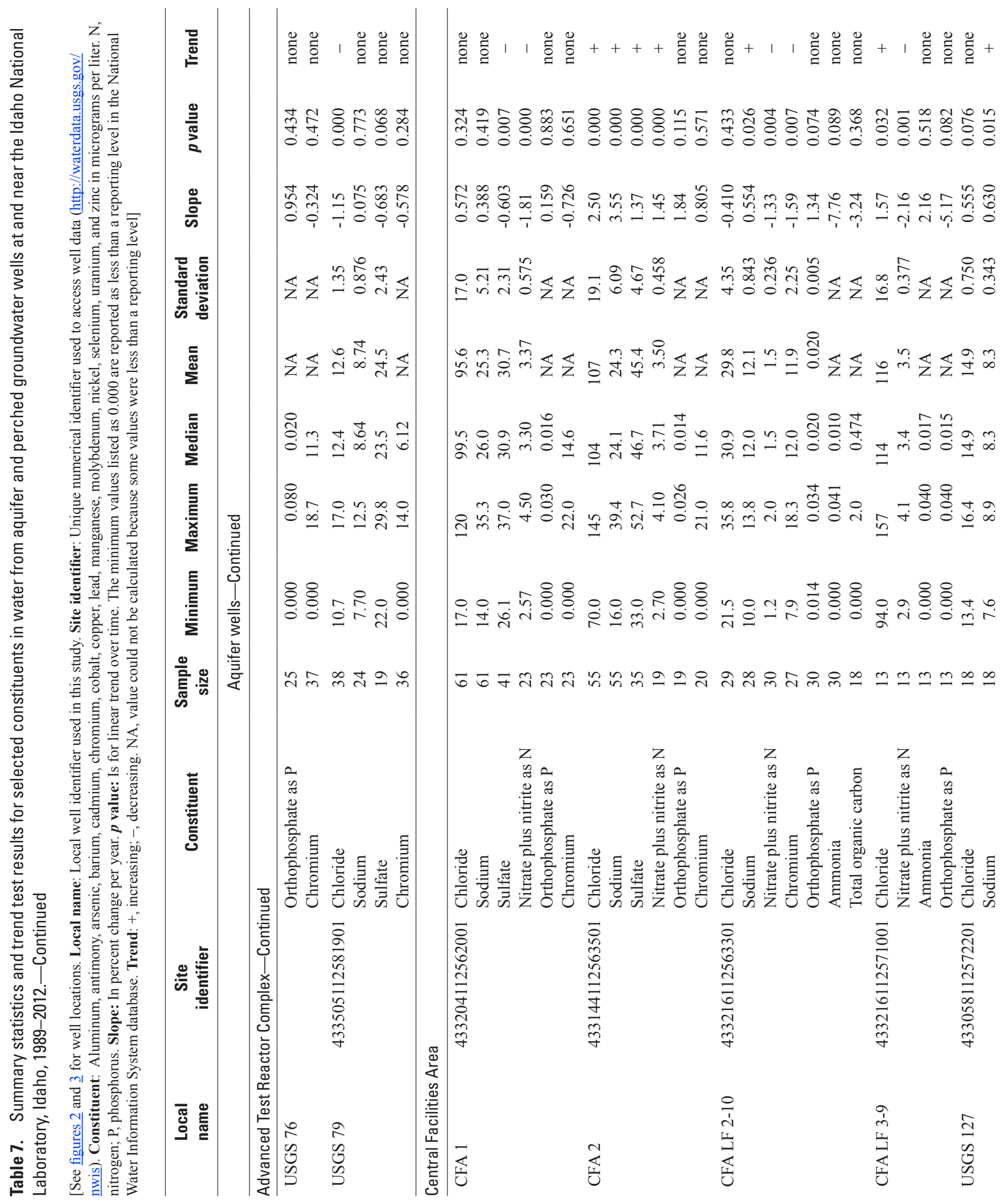




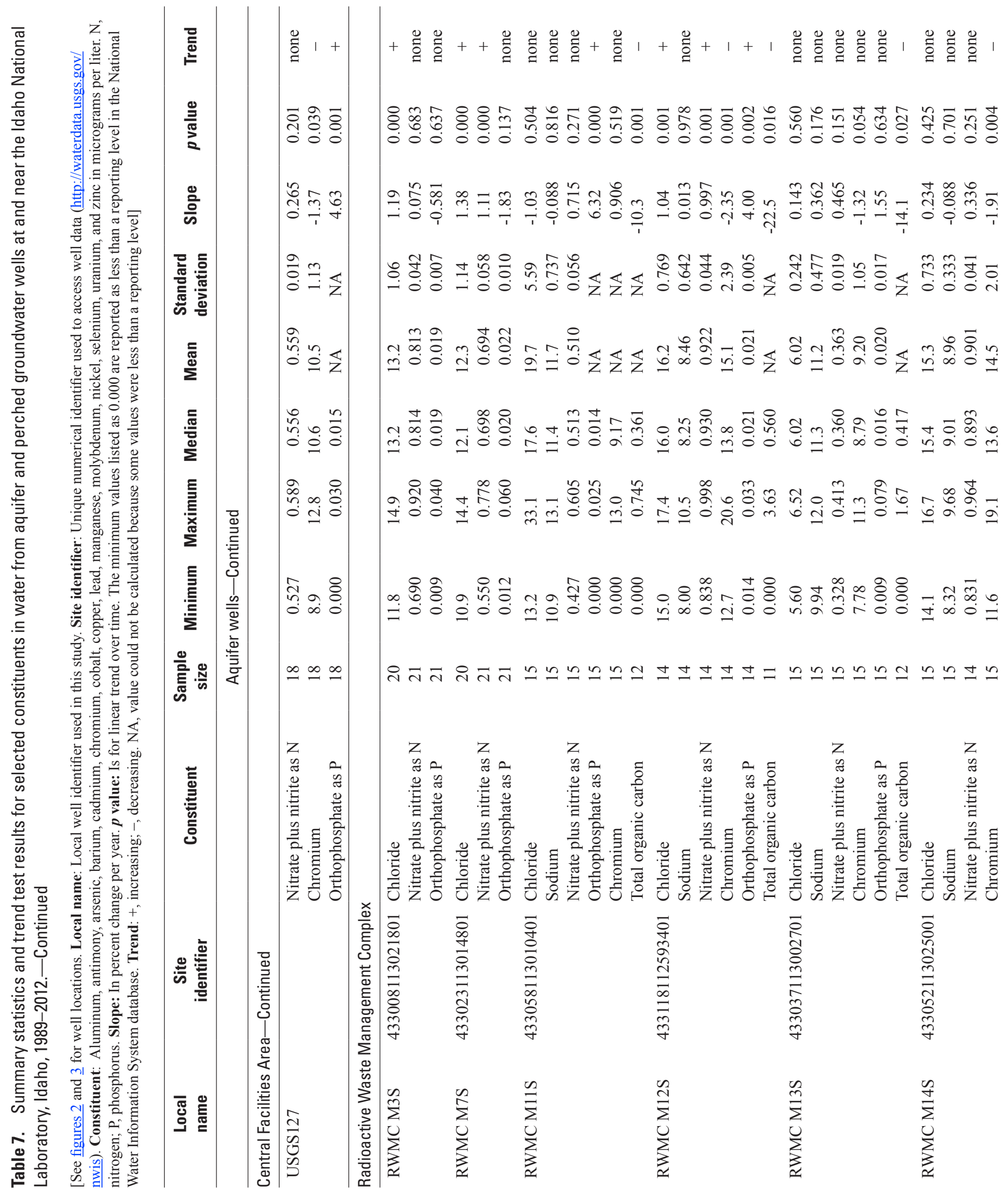




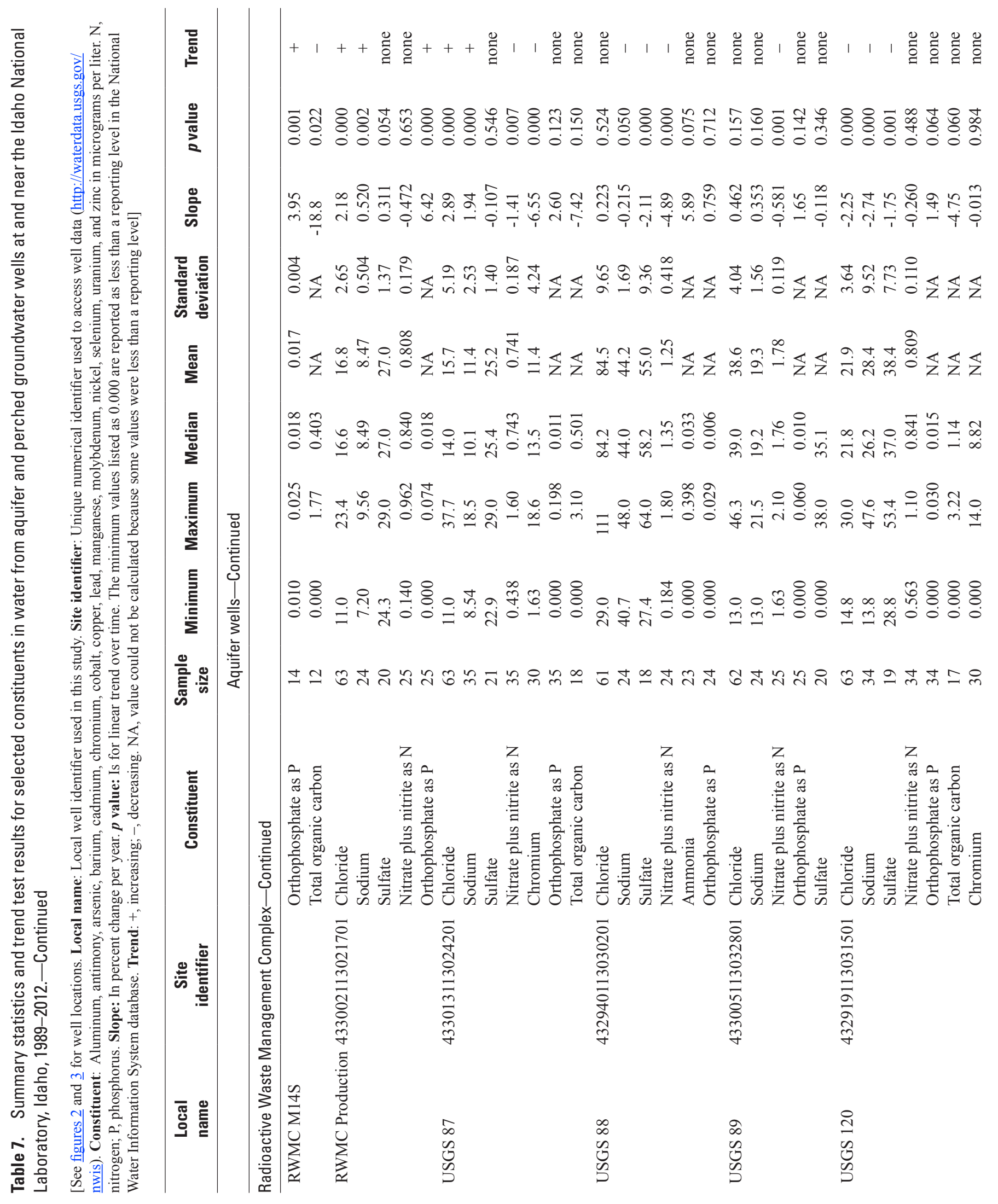



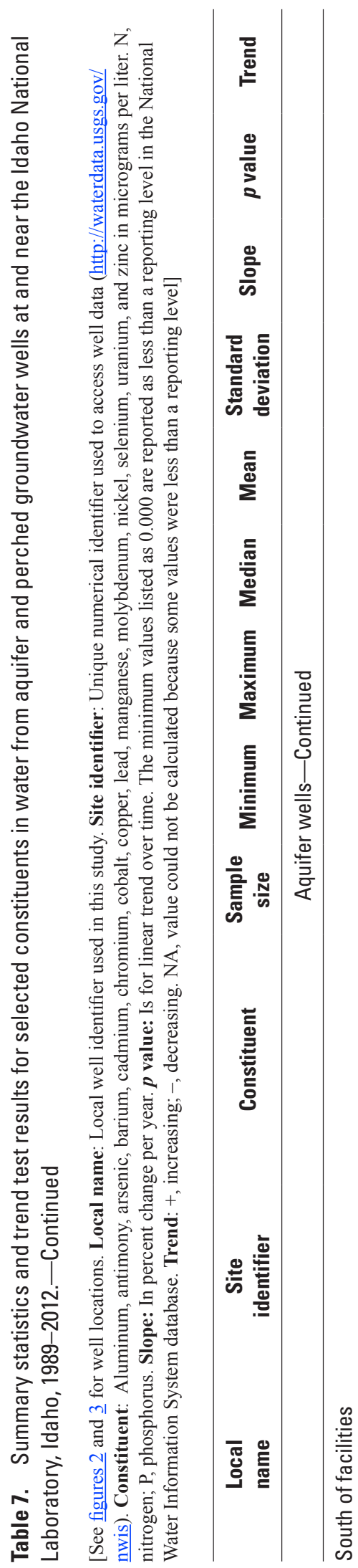

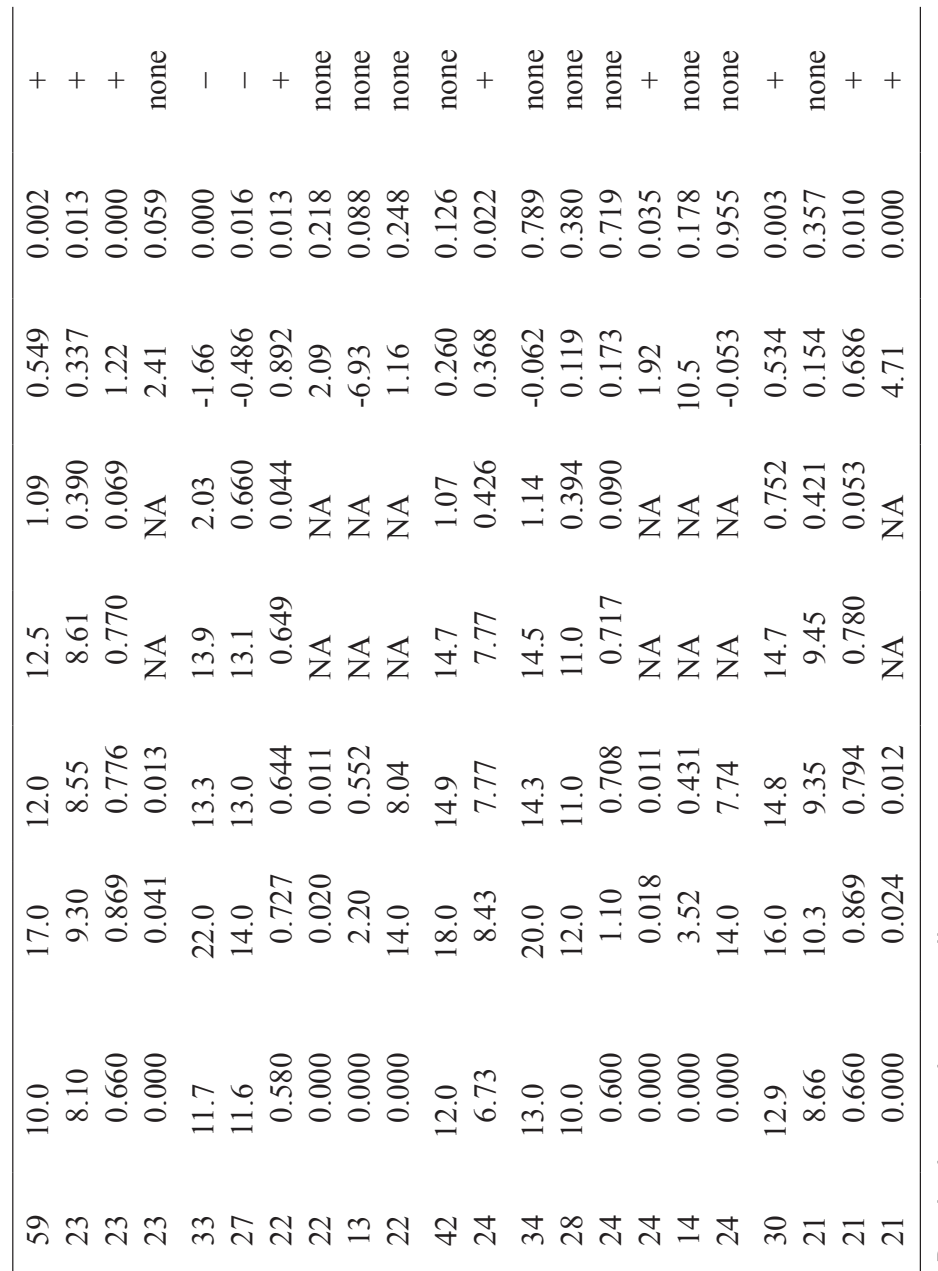

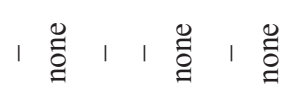

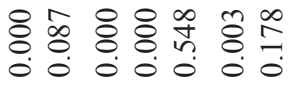

กิก

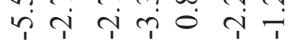

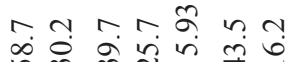

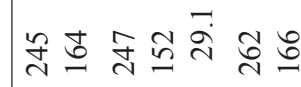

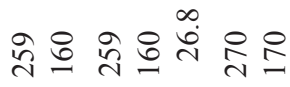

œ

ปn

$\forall=\dot{m} \pm 0$

Z

\& 2

.

वै

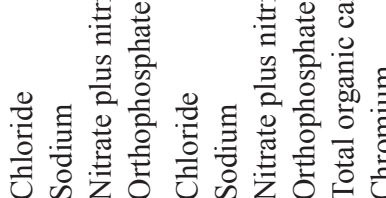

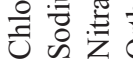

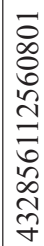

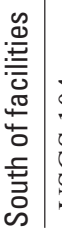

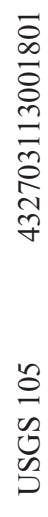

$n$
0
0
0
0
Z

สิค ค

๑ :

节

青究.
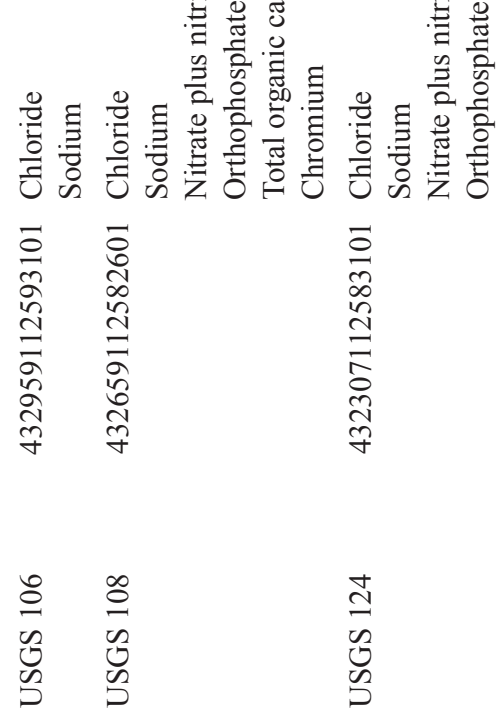

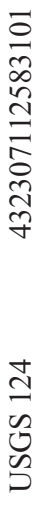

z

\& 2

. 节营 2.

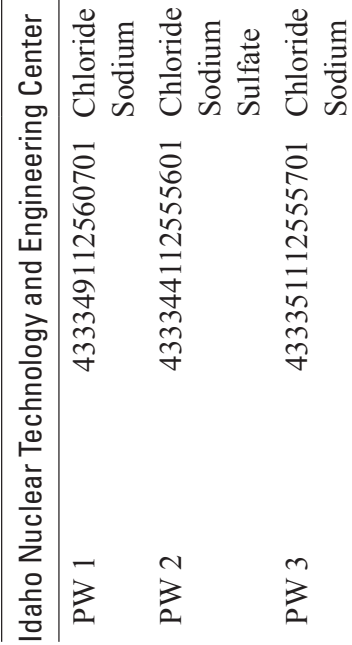




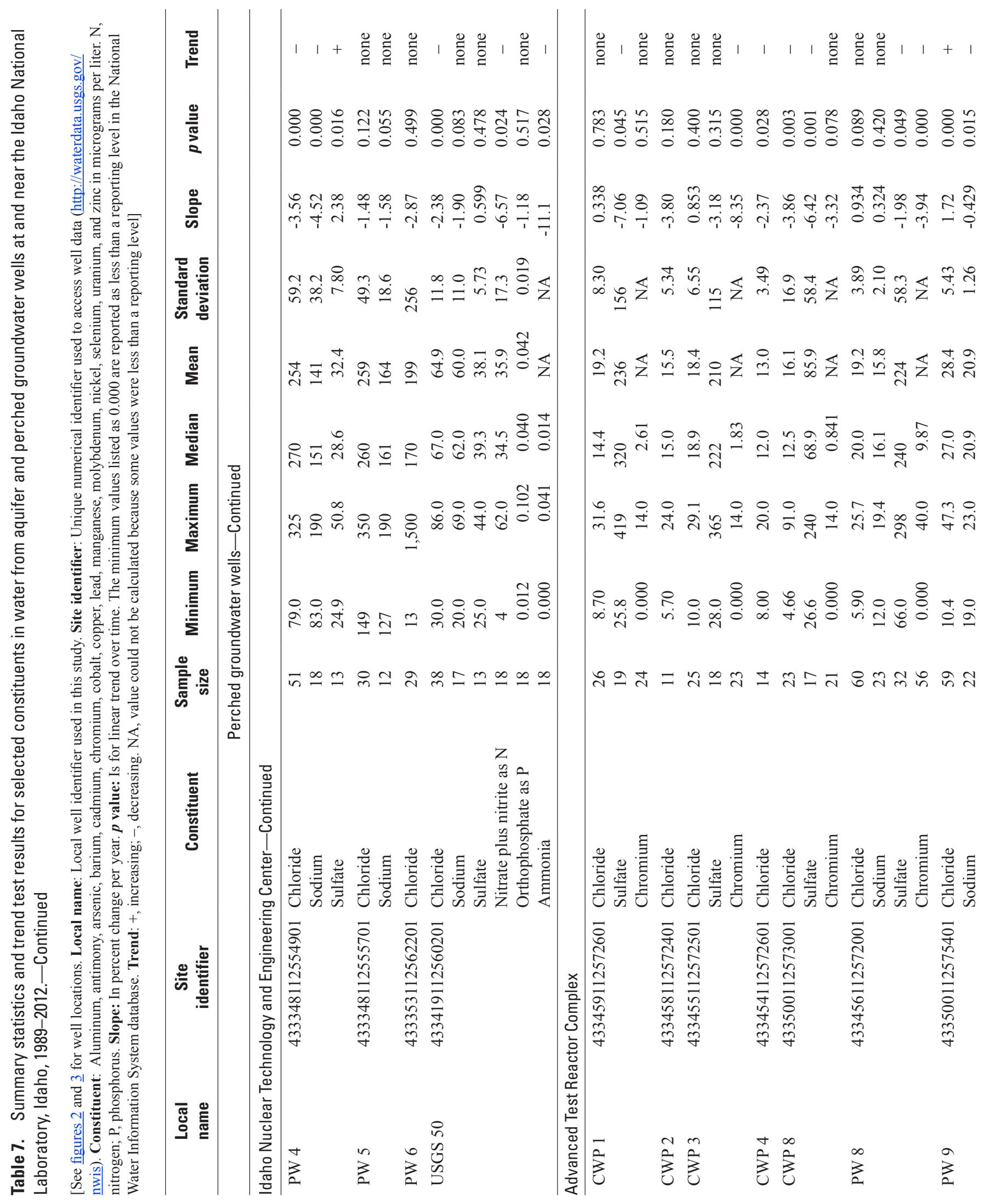




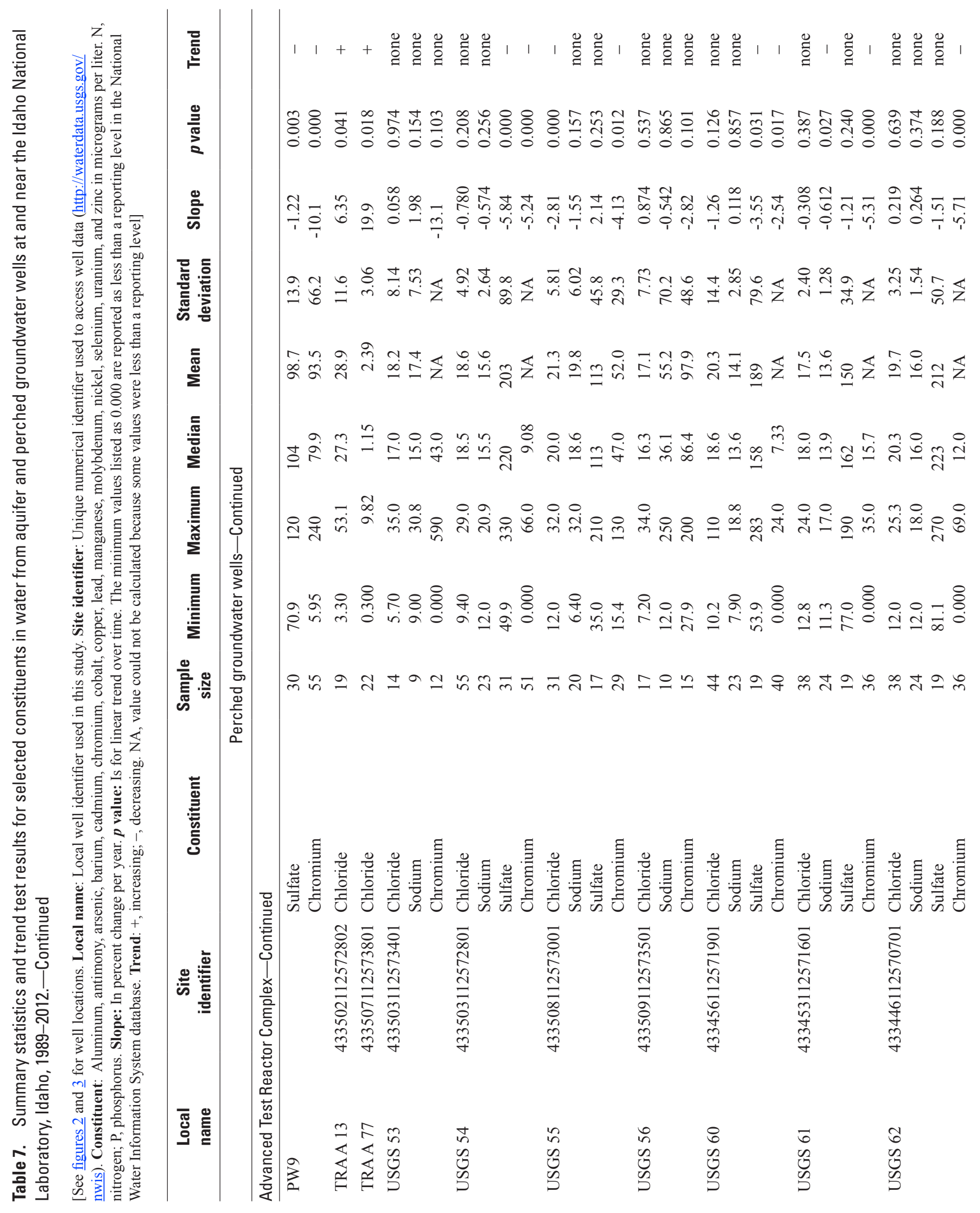




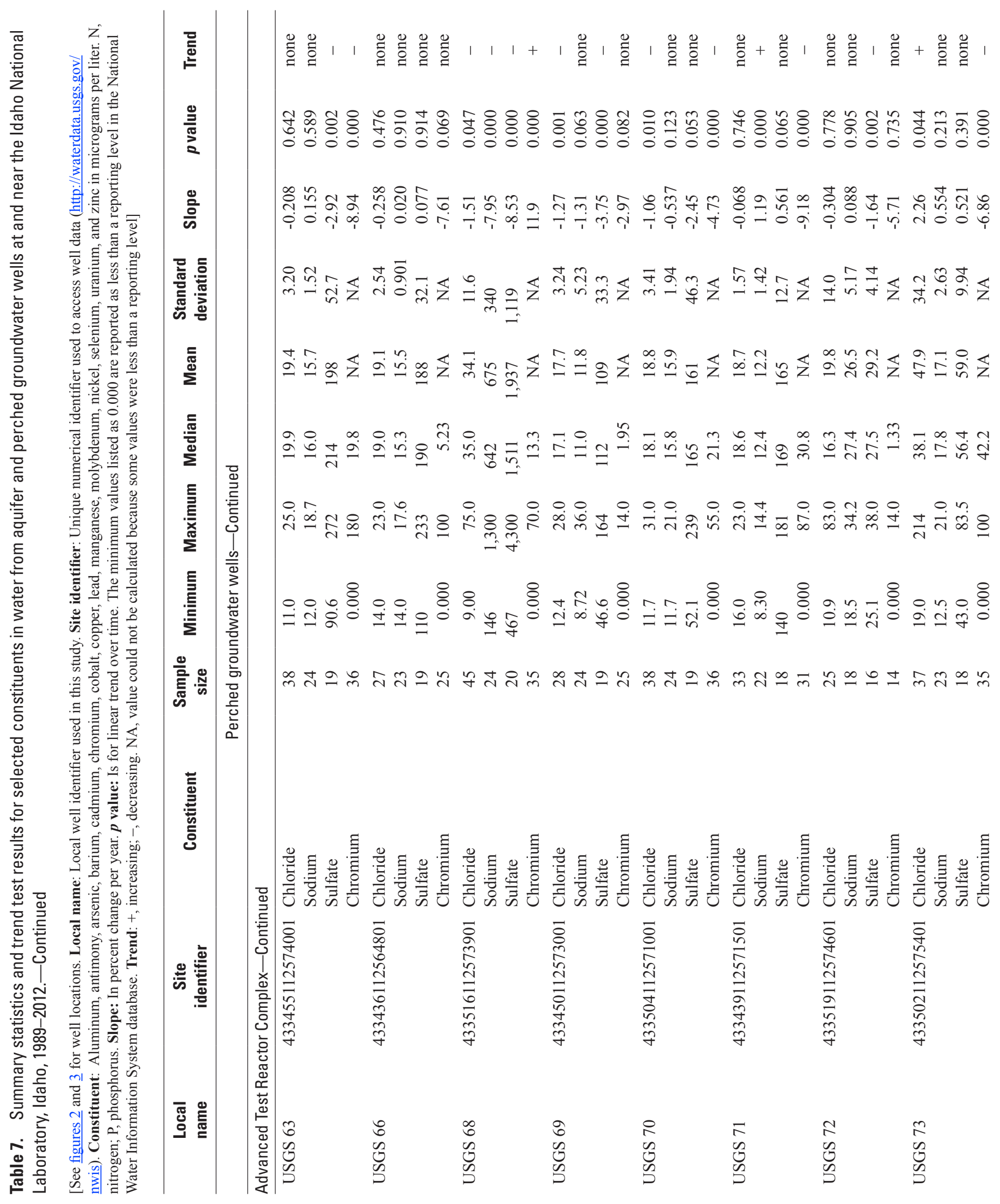




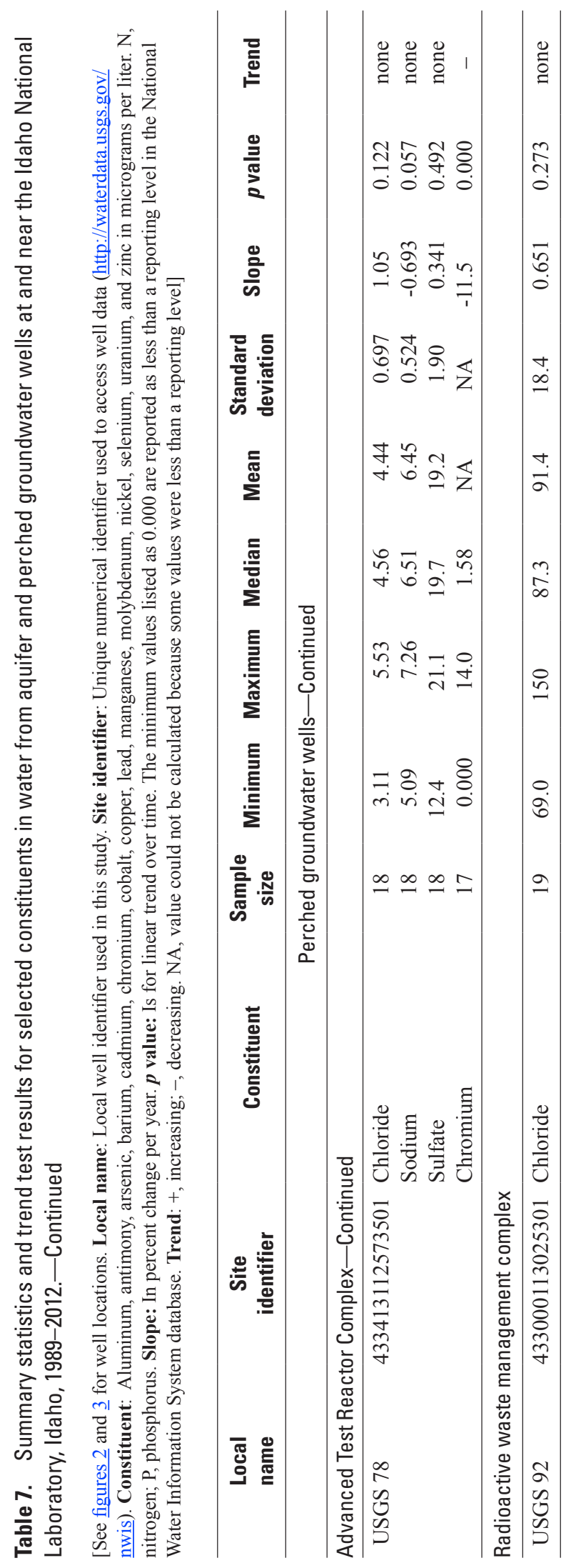




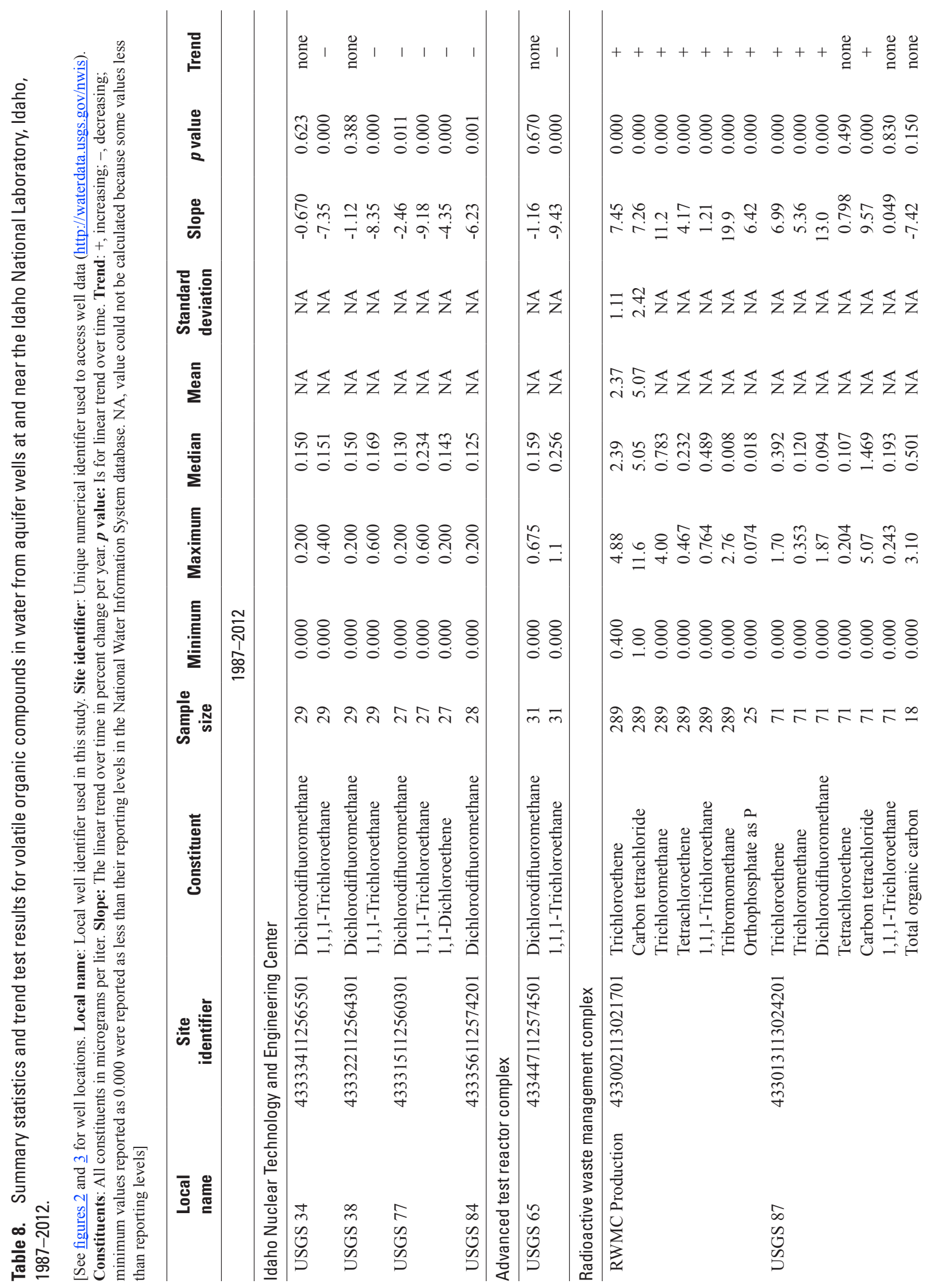




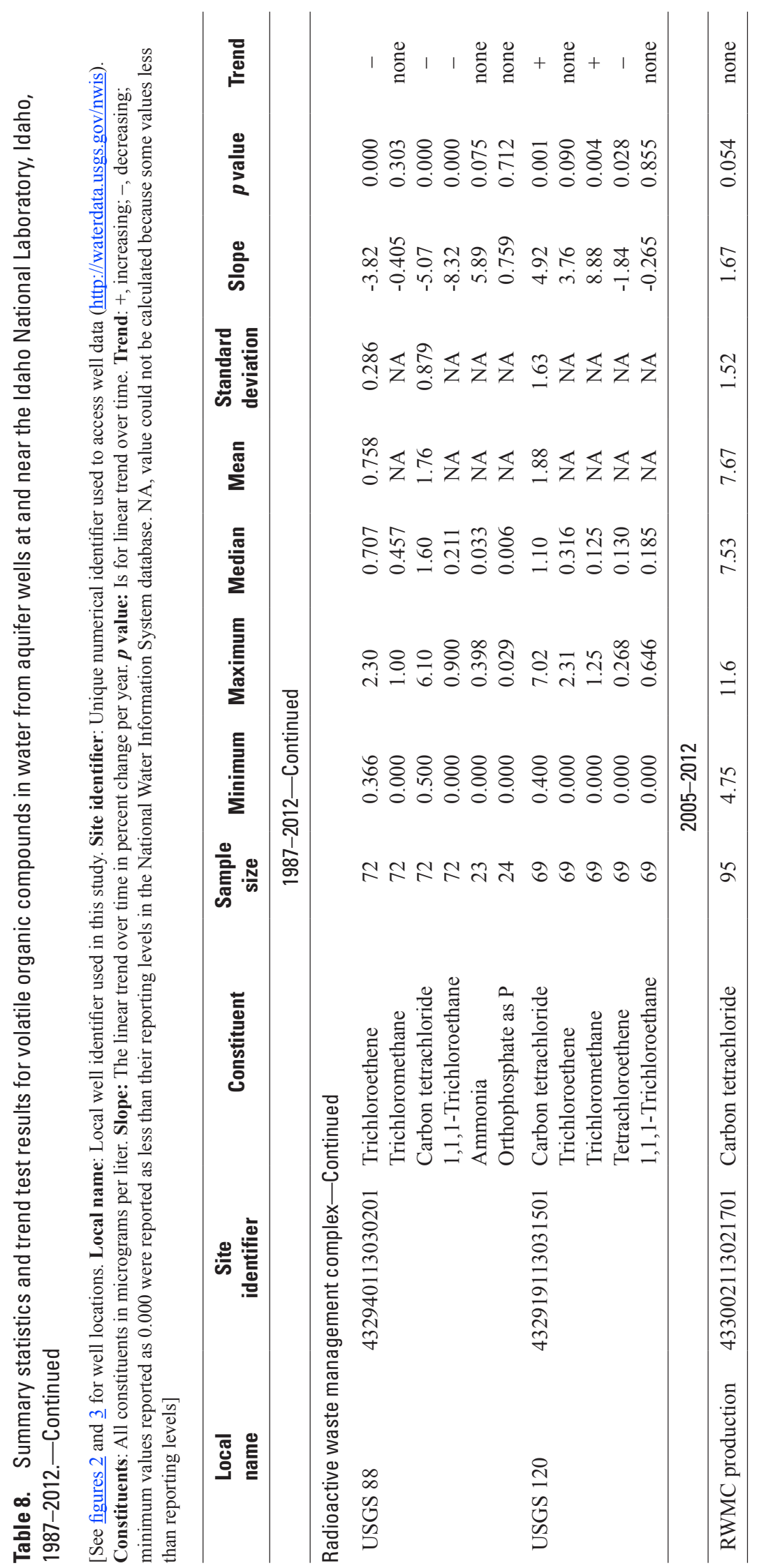




\section{Appendixes}

Appendixes A-E are PDFs and can be downloaded from http://pubs.usgs.gov/sir/2015/5003/.

Appendix A. Package 'Trends' and Processing Instructions for the 2014 Trend Analysis

Appendix B. Plots of Trend Analyses for pH, Specific Conductance, and Water Temperature from Selected Sites, 1989-201215

Appendix C. Plots of Trend Analyses for Selected Radiochemical Constituents from Selected Sites, 1981-2012

Appendix D. Plots of Trend Analyses for Selected Constituents from Selected Sites, 1989-2012

Appendix E. Plots of Trend Analyses for Volatile Organic Compounds from Selected Sites, 1987-2012 

Publishing support provided by the U.S. Geological Survey Science Publishing Network, Tacoma Publishing Service Center

For more information concerning the research in this report, contact the Director, Idaho Water Science Center

U.S. Geological Survey

230 Collins Road

Boise, Idaho 83702

http://id.water.usgs.gov 


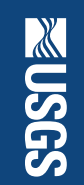

产

๗ิ

음

沗

结

을

울

ڤั

弯.

ㄱ.

를

覀

훅

为

疍

蛋

흫

글

흘

함

울

항

뭉

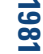

ปั

N 